ORNL/TM-12790

\title{
THIRD REPORT ON THE OAK RIDGE K-25 SITE BIOLOGICAL MONITORING AND ABATEMENT PROGRAM FOR MITCHELL BRANCH
}
R. L. Hinzman, Editor
S. M. Adams
B. R. O'Neal
T. L. Ashwood
M. J. Peterson
B. G. Blaylock
W. K. Roy
D. K. Cox
E. M. Schilling
W. D. Crumby
J. G. Smith
M. S. Greeley, Jr.
G. R. Southworth
L. A. Kszos

Environmental Sciences Division

Publication No. 4305

August 1995

MANAGED BY

LOCKHEED MARTIN ENERGY SYSTEMS, INC

FOR THE UNITED STATES

DEPARTMENT OF ENERGY 
This report has been reproduced directly from the best available copy.

Available to DOE and DOE contractors from the Otfice of Scientific and Technical Information, P.O. Box 62, Oak Ridge, TN 37831; prices availabie from (615) 576-8401, FTS 626-8401.

Available to the public from the National Technical Information Service, U.S. Department of Commerce, 5285 Port Royal Rd., Springfield, VA 22161.

This report was prepared as an account of work sponsored by an agency of the United States Government. Neither the United States Government nor any agency thereof, nor any of their employees, makes any warranty, express or implied, or assumes any legal liability or responsibility for the accuracy, completeness, or usefulness of any information, apparatus, product, or process disclosed, or represents that its use would not infringe privately owned rights. Reference herein to any specific commercial product, process, or service by trade name, trademark, manufacturer, or otherwise, does not necessarily constitute or imply its endorsement, recommendation, or favoring by the United States Government or any agency thereot. The views and opinions of authors expressed herein do not necesserily state or reflect those of the United States Government or any agency thereof. 
ENVIRONMENTAL SCIENCES DIVISION

THIRD REPORT ON THE OAK RIDGE K-25 SITE BIOLOGICAL MONITORING AND ABATEMENT PROGRAM FOR MITCHELL BRANCH

R. L. Hinzman, Editor
S. M. Adams
B. R. O'Neal ${ }^{2}$
T. L. Ashwood
M. J. Peterson
B. G. Blaylock
W. K. Roy
D. K. Cox
E. M. Schilling
W. D. Crumby
J. G. Smith
M. S. Greeley, Jr.
G. R. Southworth
L. A. Kszos

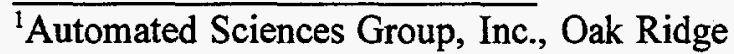

${ }^{2} \mathrm{JAYCOR}$, Inc.

\section{Environmental Sciences Division \\ Publication No. 4305}

Manuscript completed: August 1994

Date Published: August 1995

Prepared for

Water, Air, and Environmental Monitoring Department of the

Environmental Management Division

Oak Ridge K-25 Site

Oak Ridge, Tennessee 37831

Prepared by the

OAK RIDGE NATIONAL LABORATORY

Oak Ridge, Tennessee 37831-6285

managed by

MARTIN MARIETTA ENERGY SYSTEMS, INC. for the

U.S. DEPARTMENT OF ENERGY

under contract No. DE-AC05-840R21400 


\section{CONTENTS}

\section{Page}

LIST OF FIGURES $\ldots \ldots \ldots \ldots \ldots \ldots \ldots \ldots \ldots \ldots \ldots \ldots$ vii

LIST OF TABLES $\ldots \ldots \ldots \ldots \ldots \ldots \ldots \ldots \ldots \ldots \ldots \ldots \ldots \ldots$

ACRONYMS AND INITIALISMS $\ldots \ldots \ldots \ldots \ldots \ldots \ldots \ldots \ldots \ldots \ldots \ldots$

PREFACE $\ldots \ldots \ldots \ldots \ldots \ldots \ldots \ldots \ldots \ldots \ldots \ldots \ldots \ldots \ldots \ldots \ldots$

ACKNOWLEDGMENTS $\ldots \ldots \ldots \ldots \ldots \ldots \ldots \ldots \ldots \ldots \ldots \ldots$ xvii

EXECUTIVE SUMMARY $\ldots \ldots \ldots \ldots \ldots \ldots \ldots \ldots \ldots \ldots \ldots \ldots \ldots \ldots \ldots$

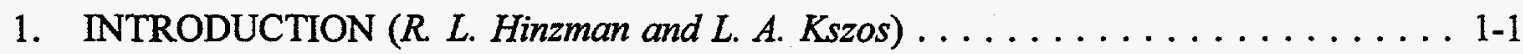

2. DESCRIPTION OF STUDY AREA (R. L. Hinzman and $W . K$ Roy) . . . . . . 2-1

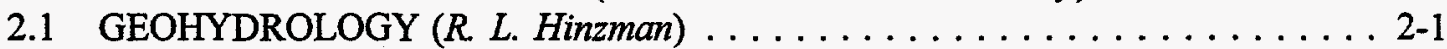

2.1.1 Mitchell Branch ... . . . . . . . . . . . . . . . . . . 2-1

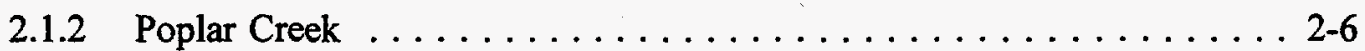

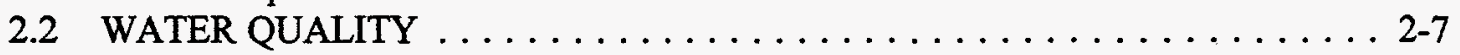

2.2.1 Description of the Oak Ridge

K-25 Site Discharges . . . . . . . . . . . . . . . 2-7

2.2.1.1 Mitchell Branch . . . . . . . . . . . . . . . 2-7

2.2.1.2 Poplar Creek . . . . . . . . . . . . . . . . . 2-8

2.2.2 NPDES Monitoring . . . . . . . . . . . . . . . . . 2-10

2.2.2.1 Mitchell Branch ..................... 2-10

2.2.2.2 Discharges to Poplar Creek ... . . . . . . . . . 2-11

2.2 .3 Temperature $(W . K$. Roy) . . . . . . . . . . . . . . . 2-11

2.3 BIOLOGICAL MONITORING SITES ................ 2-14

3. TOXICITY MONITORING $(L . A$. Kszos) $\ldots \ldots \ldots \ldots \ldots \ldots \ldots \ldots \ldots \ldots \ldots$

3.1 EFFLUENT TOXICITY AND STORM DRAIN TOXICITY . . . . . . . . 3-1

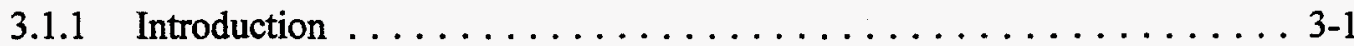

3.1.2 Materials and Methods .................... 3-2

3.1 .3 Results ......................... 3-3

3.1.3.1 CNF (K-1407-J, outfall 011) . . . . . . . . . . 3-3

3.1.3.2 K-1203 Treatment Facility . . . . . . . . . . . . 3-6

3.1.3.3 Storm drains 170,180 and $190 \ldots \ldots \ldots \ldots .6 \ldots$

3.1 .4 Discussion ......................... 3-11 


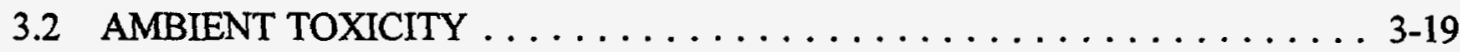

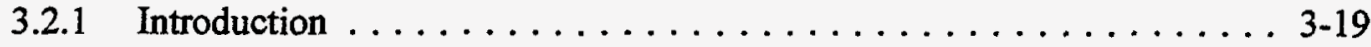

3.2.2 Materials and Methods $\ldots \ldots \ldots \ldots \ldots \ldots \ldots \ldots \ldots \ldots . . \ldots \ldots$

3.2.3 Results $\ldots \ldots \ldots \ldots \ldots \ldots \ldots \ldots \ldots \ldots \ldots \ldots \ldots \ldots \ldots \ldots \ldots \ldots, 21$

3.2.3.1 Water chemistry $\ldots \ldots \ldots \ldots \ldots \ldots \ldots \ldots \ldots \ldots, 3-21$

3.2.3.2 Fathead minnow tests $\ldots \ldots \ldots \ldots \ldots \ldots \ldots \ldots \ldots .3-22$

3.2.3.2 Ceriodaphnia tests . . . . . . . . . . . . . . . 3-28

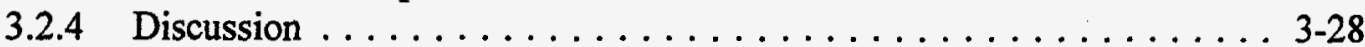

4. BIOACCUMULATION STUDIES (M. J. Peterson, G. R. Southworth

B. G. Blaylock, B. R. O'Neal, D. K. Cox, and T. L. Ashwood) . . . . . . . . . 4-1

4.1 CONTAMINANT ACCUMULATION IN AQUATIC BIOTA (SUBTASK 2a)

(M. J. Peterson and G. R. Southworth) ................... 4-1

4.1.1 Introduction $\ldots \ldots \ldots \ldots \ldots \ldots \ldots \ldots \ldots \ldots \ldots \ldots, 4-1$

4.1 .2 Methods $\ldots \ldots \ldots \ldots \ldots \ldots \ldots \ldots \ldots \ldots \ldots \ldots \ldots \ldots \ldots \ldots \ldots, 2$

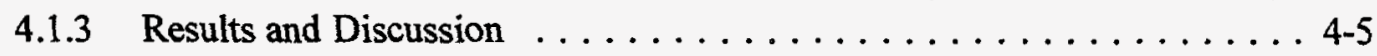

4.1.3.1 Mercury in Mitchell Branch fish ............. 4-5

4.1.3.2 Mercury in Poplar Creek fish $\ldots \ldots \ldots \ldots \ldots \ldots \ldots$ 4-10

4.1.3.3 Metals screening $\ldots \ldots \ldots \ldots \ldots \ldots \ldots \ldots \ldots$ 4-12

4.1.3.4 PCBs in Mitchell Branch fish . . . . . . . . . . . 4-16

4.1.3.5 PCBs in Poplar Creek fish $\ldots \ldots \ldots \ldots \ldots \ldots \ldots \ldots$ 4 $4-16$

4.1.3.6 PCB Screening in pond fish $\ldots \ldots \ldots \ldots \ldots \ldots \ldots$ 4-21

4.1.3.7 Organics in caged clams . . . . . . . . . . . . . . . 4-22

4.1 .4 Conclusions $\ldots \ldots \ldots \ldots \ldots \ldots \ldots \ldots \ldots \ldots \ldots \ldots \ldots, 25$

4.1.5 Future Studies ..................... 4-27

4.2 CONTAMINANT IN ACCUMULATION IN TERRESTRIAL BIOTA . . . . . 4 4-28

4.2.1 Waterfowl Monitoring (B. G. Blaylock, B. R. O'Neal, and D. K. Cox $\ldots \ldots \ldots \ldots \ldots \ldots \ldots \ldots \ldots \ldots \ldots, 4.28$

4.2.1.1Introduction $\ldots \ldots \ldots \ldots \ldots \ldots \ldots \ldots \ldots \ldots \ldots .4 .28$

4.2.1.2 Methods . . . . . . . . . . . . . . . . . 4 4-29

4.2.1.3 Results and discussions . . . . . . . . . . . . 4-30

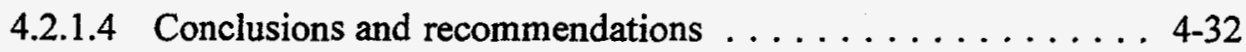

4.2.2 Raccoon Bioaccumulation Monitoring

(T. L. Ashwood) . . . . . . . . . . . . . . . . 4 4-32

4.2.2.1 Methods $\ldots \ldots \ldots \ldots \ldots \ldots \ldots \ldots \ldots \ldots \ldots \ldots, 4-33$

4.2.2.2 Results . . . . . . . . . . . . . . . 4 .33

4.2.3 Whole-Body Analyses of Representative Prey Fish $\ldots \ldots \ldots \ldots$ 4-34

4.2.3.1 Results . . . . . . . . . . . . . . . . . . 4 4-34 
5. ASSESSMENT OF FISH HEALTH (S. M. Adams, W. D. Crumby

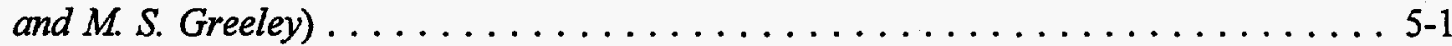

5.1 BIOINDICATORS SUBTASK $(S . M$. Adams and $W$. D. Crumby) $\ldots \ldots \ldots$. . 5-1

5.1 .1 Methods ......................... 5-2

5.1.1.1 Sampling procedures $\ldots \ldots \ldots \ldots \ldots \ldots \ldots \ldots$ 5-2

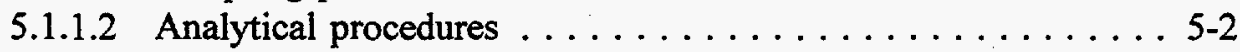

5.1.1.3 Statistical procedures $\ldots \ldots \ldots \ldots \ldots \ldots \ldots \ldots \ldots \ldots$

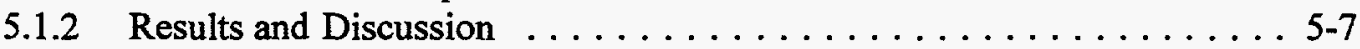

5.1.2.1 Integrated bioindicator analysis $\ldots \ldots \ldots \ldots \ldots \ldots \ldots$ 5-7

5.1.2.2 Health indicator responses . . . . . . . . . . . 5-13

5.1.2.3 Population-level analysis . . . . . . . . . . . . 5-16

5.2 REPRODUCTIVE EFFECTS SUBTASK ( $M . S$. Greeley, Jr.) . . . . . . . 5-23

5.2 .1 Introduction . . . . . . . . . . . . . . . . . . . 5 5-23

5.2 .2 Methods ......................... 5-23

5.2.2.1 Fish sampling and processing ............ 5-23

5.2 .2 .2 Gonadal assays . . . . . . . . . . . . . . . 5-24

5.2 .2 .3 Radioimmunoassays ... . . . . . . . . . . . . 5-24

5.2.2.4 Fish embryo-larval toxicity tests $\ldots \ldots \ldots \ldots \ldots \ldots \ldots 5-24$

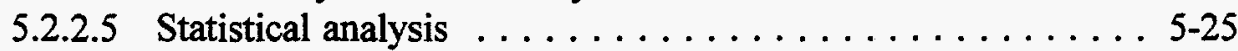

5.2 .3 Results and Discussions . . . . . . . . . . . . . . 5-26

5.2.3.1 Instream reproductive effects $\ldots \ldots \ldots \ldots \ldots \ldots \ldots \ldots$ 5-26

5.2.3.2 Embryo-larval tests for developmental toxicity ...... 5-28

5.2 .4 Conclusions . . . . . . . . . . . . . . . . . . . 5-31

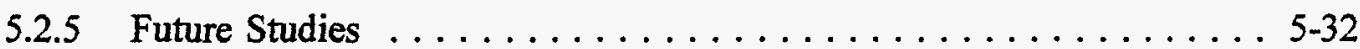

6. INSTREAM MONITORING (J. G. Smith and E. M. Schilling) . . . . . . . . 6-1

6.1 BENTHIC MACROINVERTEBRATES (J. G. Smith) . . . . . . . . . . . 6-1

6.1 .1 Introduction . . . . . . . . . . . . . . . . . . . . 6-1

6.1 .2 Materials and Methods ..................... 6-2

6.1 .3 Results ......................... 6-4

6.1.3.1 Taxonomic composition $\ldots \ldots \ldots \ldots \ldots \ldots \ldots \ldots$. $\ldots \ldots$

6.1.3.2 Abundance .....................6.5

6.1.3.3 Richness . . . . . . . . . . . . . . . . . . . . . . 6-9

6.1 .4 Discussion . . . . . . . . . . . . . . . . . . . . . 6-11

6.1.5 Summary and Conclusions/Recommendations ............. 6-14

6.1.6 Future Studies ... . . . . . . . . . . . . . . . . . 6 6-15

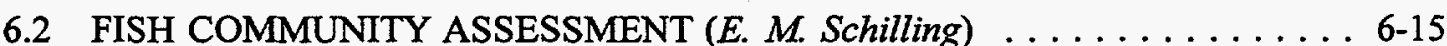

6.2 .1 Introduction . . . . . . . . . . . . . . . . . . 6-15

6.2 .2 Materials and Methods .................... 6-16

6.2 .2 .1 Field sampling procedures . . . . . . . . . . 6-16

6.2 .2 .2 Data analysis ... . . . . . . . . . . . . . 6-19

6.2.3 Results and Discussion .................... 6-19

6.2.3.1 Species richess and composition . . . . . . . . . . 6 6-19

6.2.3.2 Density and biomass . . . . . . . . . . . . . 6-30

6.2.3.3 Length-frequency . . . . . . . . . . . . . 6-31

6.2 .3 .4 Annual production .................. 6-33 
$6.2 .4 \quad$ Fish Kills $\ldots \ldots \ldots \ldots \ldots \ldots \ldots \ldots \ldots \ldots \ldots \ldots \ldots, 6,33$

6.2 .5 Conclusions $\ldots \ldots \ldots \ldots \ldots \ldots \ldots \ldots \ldots \ldots \ldots \ldots, 6,35$

6.2 .6 Future Studies $\ldots \ldots \ldots \ldots \ldots \ldots \ldots \ldots \ldots \ldots \ldots \ldots, 6-35$

7. SUMMARY OF STREAM HEALTH (L. A. Kszos and R. L. Hinzman) $\ldots \ldots \ldots 7-1$

8. REFERENCES $\ldots \ldots \ldots \ldots \ldots \ldots \ldots \ldots \ldots \ldots \ldots \ldots \ldots \ldots \ldots \ldots$ 8-1

Appendix A. WATER QUALITY DATA FOR MITCHELL BRANCH $\ldots \ldots \ldots \ldots$ A-1

Appendix B. RESULTS OF AMBIENT TOXICITY TESTS AND WATER QUALITY MEASUREMENTS, JANUARY 1990 THROUGH JANUARY 1994 . . . B-1

Appendix C. RESULTS OF QUALITY ASSURANCE/QUALITY CONTROL ANALYSES OF FISH SAMPLES $\ldots \ldots \ldots \ldots \ldots \ldots \mathrm{C}-1$

Appendix D. CHECKLIST OF BENTHIC MACROINVERTEBRATE TAXA FROM MITCHELL BRANCH, OCTOBER 1986 THROUGH

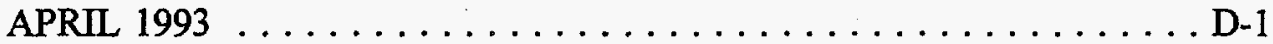

Appendix E. F-VALUES AND P-VALUES FOR NESTED ANOVAS AND REGRESSION ANALYSES $\ldots \ldots \ldots \ldots \ldots \ldots \ldots \ldots$ E-1

Appendix F. SEASONAL REGRESSION LINES FOR DENSITY, TOTAL RICHNESS AND EPT RICHNESS $\ldots \ldots \ldots \ldots \ldots \ldots \ldots$ F-1

Appendix G. LENGTH FREQUENCY DISTRIBUTION OF FISHES IN MITCHELL BRANCH G-1 


\section{FIGURES}

Figure

Page

2.1 Map of the Oak Ridge area showing locations of sampling sites on Poplar Creek . . . . . . . . . . . . . . . . . . . . . . . . . . . . 2-2

2.2 Map of Mitchell Branch and a portion of the Oak Ridge K-25 Site showing the locations of the biological monitoring sites in relation to selected storm drains and the K-1407-E/F ponds and the K-1407-J basin, which replaced the K-1407-B pond on November 1, 1988

2.3 Map of the Oak Ridge area showing locations of the reference (control) sites

2.4 Weekly mean temperatures for Mitchell Branch kilometer 0.5, 1987-1994, Grassy Creek kilometer 2.4, 1987-1991, and Scarboro Creek kilometer 2.2, 1991-1994

3.1 Annual mean conductivity, alkalinity, and hardness for each site in Mitchell Branch, 1990-1993

3.2 Multi-year mean conductivity, alkalinity, and hardness for each site in Mitchell Branch

3.3 Mean percentage survival and growth of fathead minnows in water for each site in Mitchell Branch, 1990-1993

3.4 Mean percentage survival and reproduction of Ceriodaphnia for each site in Mitchell Branch, 1990-1993

4.1 Mean concentrations of mercury in sunfish species from waters on the DOE Oak Ridge Reservation

4.2 Mean concentrations of PCBs in sunfish species (Lepomis auritus, L. macrochirus, Ambloploites rupestris) from waters on the DOE Oak Ridge Reservation

4.3 Number of Canada geese observed at the K-25 Site during June 1993March 1994 compared to June 1992-March 1993 
Figure

5.1 Segregation of integrated health responses for male redbreast sunfish collected in 1989 at Mitchell Branch and three reference streams $\ldots \ldots \ldots \ldots \ldots \ldots \ldots \ldots \ldots \ldots \ldots . \ldots \ldots$. . . . . . . . . . . . . . . .

5.2 Segregation of integrated health responses for male redbreast sunfish collected in 1990 at Mitchell Branch and three reference streams

5.3 Segregation of integrated health responses for male redbreast sunfish collected in 1991 at Mitchell Branch and three reference streams

5.4 Segregation of integrated health responses for male redbreast sunfish collected in 1992 at Mitchell Branch and three reference

5.5 Length frequency of redbreast sunfish collected in Mitchell Branch from 1989 to 1992

5.6 Age frequency of redbreast sunfish collected in Mitchell Branch from 1989 to 1992

5.7 Mean total length at capture (cm) for redbreast sunfish collected in Mitchell Branch from 1989 to 1992

5.8 Back-calculated length at age $(\mathrm{cm})$ for redbreast sunfish collected in Mitchell Branch from 1990 to 1992

5.9 Segregation of integrated reproductive responses of female redbreast sunfish collected in 1993 prior to the onset of the reproductive season

6.1 Mean total density, mean total richness and mean richness of the Ephemeroptera, Plecoptera and Trichoptera (EPT richness) of the benthic macroinvertebrate communities in Mitchell Branch, October 1986-April 1993

6.2 Mean percent composition (i.e., percentage of total density) of selected benthic macroinvertebrate taxonomic groups in Mitchell Branch, October 1986-April 1993 


\section{TABLES}

Table

2.1 Number of days of zero discharge in upper Melton Branch at kilometer 1.93 (USGS gaging station 03537100 ) . . . . . . . . . . 2-6

2.2 Partial list of events that may have affected water quality in Mitchell Branch, 1987 through 1994

2.3 Location of the biological monitoring sites on Mitchell Branch

Poplar Creek and unnamed tributaries

3.1 Toxicity test results for Central Neutralization Facility

(CNF; K-1407-J) and K-1203

3.2 Average water quality parameters measured during toxicity tests of Central Neutralization Facility (K-1407-J) and K-1203

3.3 Toxicity test results for storm drains 170,180 , and 190

3.4 Average water quality parameters measured during toxicity tests of storm drains 170,180 , and 190

3.5 Summary (mean and range) of total residual chlorine measured during toxicity tests of storm drains and ambient waters from Mitchell Branch

3.6 Tukey groupings for conductivity and hardness for tests completed during 1990-1994

3.7 Number of fathead minnow and Ceriodaphnia tests where no toxicity, acute toxicity, or chronic toxicity was observed for Mitchell Branch Sites

4.1 Mercury concentrations in bluegill (Lepomis macrochirus) and redbreast sunfish ( $L$. auritus) collected from Mitchell Branch, Poplar Creek and the Clinch River

4.2 Mean concentrations and condition factors in blacknose dace (Rhinichthys atratulus) 
4.3 Mean metal concentrations in redbreast sunfish from Mitchell

Branch, 1991-1993 . . . . . . . . . . . . . . . . . . . . . . . . . 4-14

4.4 Mean metal concentrations in sunfish collected in the

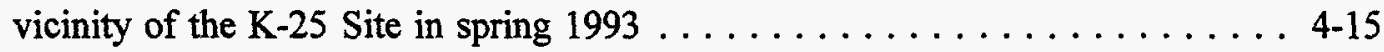

4.5 Polychlorinated biphenyl concentrations (Arochlor-1254 +1260 ) in redbreast sunfish (Lepomis auritus) and bluegill (L. macrochirus) collected from Mitchell Branch and Poplar Creek sites, 1987-1993

4.6 Average concentrations of polychlorinated biphenyls and fraction of fish exceeding the Food and Drug Administration limit, for channel catfish from White Oak Creek embayment, the Clinch River, lower Poplar Creek, and Melton Hill Reservoir 1986-1993 .

4.7 Polychlorinated biphenyl concentrations in fish from ponds near the K-25 Site in spring 1993

4.8 Mean concentrations of organic compounds detected in duplicate samples of caged clams (Corbicula fluminea) at sites near K-25, 1991-1993 . . . . . . . . . . . . . . . . . . . . . . . . 4-24

5.1 Statistical linear distances (Mahalanobis distances) between the integrated bioindicator responses of fish collected from Mitchell Branch and each reference from 1989 through 1992

5.2 Ranking of bioindicator response variables which were significant in discriminating among the four sample sites each year . . . . . . . . 5-14

5.3 Comparison of mean total length of redbreast sunfish at capture $\ldots \ldots \ldots . .5-21$

5.4 Comparison of reproductive bioindicators in female redbreast sunfish, Lepomis auritus, collected from Mitchell Branch and several reference streams at the beginning of the 1993 reproductive season

5.5 Mahalanobis distances and associated probability values for site-to-site comparisons of the integrated reproductive condition of female redbreast sunfish sampled from Mitchell Branch and various reference sites at the beginning of the 1993 reproductive season 
5.6 Results of quarterly medaka embryo-larval toxicity tests of ambient water samples from Mitchell Branch and Poplar Creek, 1993-1994

6.1 Length, mean width, mean depth, surface area, and pool-riffle ratio of fish sampling sites in Mitchell Branch and in two reference streams, Grassy Creek and Scarboro Creek, for each sampling date

6.2 Fish species composition in Mitchell Branch, Grassy Creek, and Scarboro Creek, fall 1990 through fall 1993

6.3 Total fish density, total biomass, and species richness in Mitchell Branch and in two reference streams; Grassy Creek and Scarboro Creek, for fall 1990-1993, and spring 1991-1993

6.4 Fish densities and biomass in Mitchell Branch, and in two reference streams, Grassy Creek and Scarboro Creek, for fall 1990

6.5 Fish densities and biomass in Mitchell Branch, and in two reference streams, Grassy Creek and Scarboro Creek, for spring 1991

6.6 Fish densities and biomass in Mitchell Branch, and in two reference streams, Grassy Creek and Scarboro Creek, for fall 1991

6.7 Fish densities and biomass in Mitchell Branch, and in two reference streams, Grassy Creek and Scarboro Creek, for spring 1992

6.8 Fish densities and biomass in Mitchell Branch, and in two reference streams, Grassy Creek and Scarboro Creek, for fall 1992

6.9 Fish densities and biomass in Mitchell Branch, and in two reference streams, Grassy Creek and Scarboro Creek, for spring 1993 
6.10 Fish densities and biomass in Mitchell Branch, and in two reference streams, Grassy Creek and Scarboro Creek, for fall 1993

6.11 Annual production rates in Mitchell Branch, Grassy Creek and Scarboro Creek, from spring 1990 to spring 1993 6-34 


\section{ACRONYMS AND INITIALISMS}

\begin{tabular}{|c|c|}
\hline ALT & alanine aminotransferase \\
\hline ANOVA & analysis of variance \\
\hline ASO & Analytical Services Organization \\
\hline $\mathrm{BCK}$ & Bear Creek kilometer \\
\hline BMAP & Biological Monitoring and Abatement Program \\
\hline BMP & best management plan \\
\hline BUN & blood urea nitrogen \\
\hline CDFC & condition factor \\
\hline CNF & Central Neutralization Facility \\
\hline CRK & Clinch River kilometer \\
\hline CRRI & Clinch River Remedial Investigation \\
\hline DDT & Dichlorodiphenyl-trichloroethone-a pesticide \\
\hline DO & dissolved oxygen \\
\hline DOE & U.S. Department of Energy \\
\hline EDTA & ethylenediaminetetracetic acid \\
\hline EFK & East Fork Poplar Creek kilometer \\
\hline EFPC & East Fork Poplar Creek \\
\hline EPA & U.S. Environmental Protection Agency . \\
\hline EPT & Ephemeroptera, Plecoptera, and Tricoptera \\
\hline EROD & 7-ethoxyresorufin 0-deethylase \\
\hline ESD & Environmental Sciences Division \\
\hline FDA & U.S. Department of Agriculture Food and Drug Administration \\
\hline GCK & Grassy Creek kilometer \\
\hline GC/ECD & gas chromatography/electron capture detector \\
\hline GC/MS & gas chromatography/mass spectrometry \\
\hline GLM & general linear model \\
\hline GSI & gonadal-somatic index \\
\hline $\mathrm{LC}_{50}$ & concentration level (of toxin) that kills $50 \%$ of test organisms \\
\hline LFPMA & functional parenchyma in liver \\
\hline LMACA & macrophage aggregates in liver \\
\hline LPARS & liver parasites \\
\hline LSI & liver-somatic index \\
\hline MAF & mean annual flow \\
\hline MEK & Melton Branch kilometer \\
\hline
\end{tabular}


MGD

MHR

MIK

$\mathrm{NAD}(\mathrm{H})$

$\mathrm{NADP}(\mathrm{H})$

NOEL

NPDES

NTK

ORGDP

ORNL

ORR

PAH

PCB

PCK

PHK

PGV

PPM

QA

RIA

SAS

SCK

SD

SE

STP

TDEC

TDS

TL

TRC

TRK

TSCA

TSS

TVA

USGS

VSI

WCK

WOC

WOL million gallons per day

Melton Hill Reservoir

Mitchell Branch kilometer

nicotinamide-adenine dinucleotide (reduced form)

nicotinamide-adenine dinucleotide phosphate (reduced form)

no observed-effect level

National Pollutant Discharge Elimination System

Northwest Tributary kilometer

Oak Ridge Gaseous Diffusion Plant

Oak Ridge National Laboratory

Oak Ridge Reservation

polycyclic aromatic hydrocarbons

polychlorinated biphenyl

Poplar Creek kilometer

Pinhook Branch kilometer

preliminary guidance values

parts per million

quality assurance

radioimmunoassay

Statistical Analysis System

Scarboro Creek kilometer

storm drain

standard error

sewage treatment plant

Tennessee Department of Environment and Conservation

total dissolved solids

total length

total residual chlorine

Tennessee River kilometer

Toxic Substances Control Act

total suspended solids

Tennessee Valley Authority

U.S. Geological Survey

visceral-somatic index

White Oak Creek kilometer

White Oak Creek

White Oak Lake 


\section{PREFACE}

On September 11, 1986, a modified National Pollutant Discharge Elimination System (NPDES) permit was issued for the Oak Ridge Gaseous Diffusion Plant (now referred to as the Oak Ridge K-25 Site), a former uranium-enrichment production facility operated by Martin Marietta Energy Systems, Inc., for the U.S. Department of Energy. As required in Part III (L) of the permit, a plan for the biological monitoring of Mitchell Branch (K-1700 stream) was prepared and submitted for approval to the U.S. Environmental Protection Agency and the Tennessee Department of Environment and Conservation (Loar et al. 1992a). The plan, referred to as the Oak Ridge K-25 Site Biological Monitoring and Abatement Program (BMAP), described biomonitoring activities that would be conducted over the duration of the permit.

On October 1, 1992, a renewed NPDES permit was issued for the K-25 Site. A biological monitoring plan was submitted and approved for Mitchell Branch, Poplar Creek, Poplar Creek embayment of the Clinch River and any unnamed tributaries of these streams (Kszos et al. 1993).

This document is the third in a series of reports presenting the results of the studies that were conducted from June 1990 through December 1993 for the Oak Ridge K-25 Site BMAP although studies conducted outside this time period are included as appropriate. This report also addresses any significant modifications in the scope of work outlined in Kszos et al. 1993, but does not address changes in the scope of the BMAP which were implemented in March of 1995. Thus, the "future studies" sections in this report, written in early 1994, do not accurately reflect work conducted in 1995. The most recent changes to BMAP were directed by the K-25 Site office and approved by the Tennessee Department of Conservation and will be outlined in a new biological monitoring plan for the K-25 Site. 


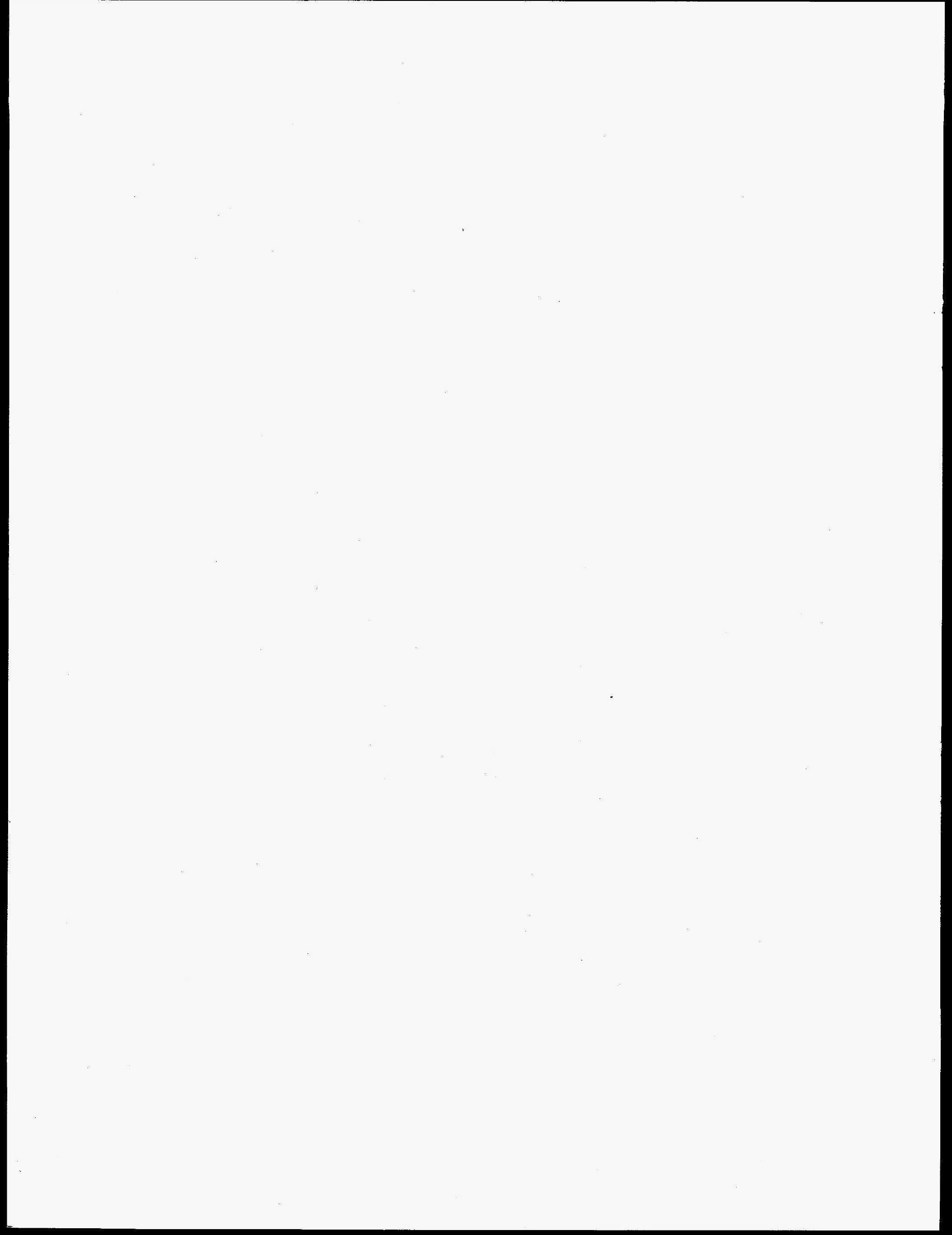




\section{ACKNOWLEDGMENTS}

We thank B. K. Beane, P. W. Braden, L. S. Ewald, K. J. McAfee, G. W. Morris, T. L. Phipps, J. R. Sumner, W. Session and L. F. Wicker for their assistance in the toxicology laboratory and/or field. We thank J. R. Sumner and L. F. Wicker for constructing figures and tables for the toxicology monitoring section. Thank you to T. L. Phipps for coordinating the quality assurance program. We thank Roger Petrie, JAYCOR Inc., who assisted with field collections, sample processing, and data tabulation for the bioaccumulation task. The assistance of the following contributors to the fish health task was invaluable and greatly

appreciated. L. J. Ivey, M. K. McCracken, C. Wilson and S. L. Nimela conducted the medaka embryo-larval tests described in this report. S. L. Nimela participated in the field sampling of redbreast sunfish, and supervised gonadal analyses. $M$. Wood, C. Wilson and B. Beech painstakingly picked apart ovarian tissues and counted oocytes in their sleep. We thank B. F. Clark, W. C. Dickinson, A. W. McWhorter, and J. A. Wojtowicz of JAYCOR, Inc., for processing benthic macroinvertebrate samples. We thank B. A. Carrico, B. F. Clark, R. P. Hoffmeister, W. C. Kyker, W. K. Roy, M. G. Ryon, L. M. Stubbs, and D. K. Weaver for assistance with field collections for the fish community studies. We are grateful to C. C. Coutant, R. M. Cushman, and G. K. Eddlemon, who reviewed a draft of this report and provided many helpful suggestions and comments. Finally, thanks to E. B. Bryant for editorial support and T. K. Sawyer for electronic publishing of this document. This work was funded by the Environmental Management Division of the Oak Ridge K-25 Site. The K-25 Site and ORNL are managed by Martin Marietta Energy Systems, Inc., under contract DE-AC05-84OR21400 with the U.S. Department of Energy. 



\section{EXECUTIVE SUMMARY}

As a condition of the modified National Pollutant Discharge Elimination System (NPDES) permit issued to the Oak Ridge Gaseous Diffusion Plant (ORGDP; now referred to as the Oak Ridge K-25 Site) on September 11, 1986, a Biological Monitoring and Abatement Program (BMAP) was developed for the receiving stream (Mitchell Branch or K-1700 stream).

On October 1, 1992, a renewed NPDES permit was issued for the K-25 Site. A biological monitoring plan was submitted for Mitchell Branch, Poplar Creek, Poplar Creek Embayment of the Clinch River and any unnamed tributaries of these streams. The objectives of BMAP are to (1) demonstrate that the effluent limitations established for the Oak Ridge K-25 Site protect and maintain the use of Mitchell Branch for growth and propagation of fish and other aquatic life and (2) document the effects on stream biota resulting from operation of major new pollution abatement facilities, including the Central Neutralization Facility (CNF) and the Toxic Substances Control Act (TSCA) incinerator. The BMAP consists of four tasks: (1) toxicity monitoring; (2) bioaccumulation monitoring; (3) assessment of fish health; and (4) instream monitoring of biological communities, including benthic macroinvertebrates and fish. This document, the third in a series, reports on the results of the Oak Ridge K-25 Site BMAP; it describes studies that were conducted over various periods of time between June 1990 and December 1993, although monitoring conducted outside this time period is included, as appropriate.

\section{Background}

Mitchell Branch is a small stream that originates near the northeast boundary of the Oak Ridge K-25 Site; it flows only $1.5 \mathrm{~km}$ from its headwaters to its mouth on Poplar Creek at kilometer 7.0. The water quality of Mitchell Branch is influenced by the geology of the drainage basin, effluents entering the stream via storm drains, leachate from waste disposal sites, and remediation projects. The water quality of lower Mitchell Branch was characterized by (1) moderate levels of dissolved solids and occasionally high total suspended solids; (2) relatively low levels of nutrients; (3) elevated levels of some metals and organics; and (4) 
elevated temperatures. The geology of Mitchell Branch watershed contributes to periods of no flow in its upper reaches, whereas flow in its lower reaches is augmented by as much as $10 \%$ by discharges from the Oak Ridge K-25 Site. Samples for BMAP were routinely collected from eight primary sites in Mitchell Branch. The site farthest upstream served as an undisturbed reference; the remaining sites were selected to coincide with the ambient NPDES monitoring station or to bracket known areas or sources of ecological disturbance. Additional reference sites on nearby streams were used for some tasks, depending on the specific objectives of the task.

\section{Toxicity Testing}

Tests were conducted bimonthly over the 1990 to 1994 sampling period with Ceriodaphnia dubia and fathead minnow larvae to assess the acute and chronic toxicity of (1) effluent from the CNF (K-1407-J) and the K-1203 Treatment Facility, (2) effluent from storm drains (SDs) 170, 180 and 190, and (3) ambient water from six sites on Mitchell Branch and five sites on Poplar Creek.

In February 1990 and April 1991 effluent from CNF would have exceeded the $2.11 \%$ no observed effect level (NOEL) in the new permit. However, the K-25 Site was operating under the old permit at that time, therefore, no violation occurred. CNF has not exceeded permit limits since the new permit became effective.

In July 1993 and March 1994, effluent from K-1203 exceeded the 4.2\% NOEL limit. Confirmatory tests were conducted within 2 weeks of each exceedance and no toxicity was observed.

Full strength effluent from SDs 170 and 190 has consistently reduced survival and/or reproduction of Ceriodaphnia. Effluent from SD 180 reduced Ceriodaphnia survival or reproduction in less than half of the tests conducted. Samples of water from Mitchell Branch collected downstream of the storm drains only occasionally reduced survival or reproduction of Ceriodaphnia. Following dechlorination of the storm drains in 1991, survival of the Ceriodaphnia in laboratory tests was high during the first 48 hours of the test, thus indicating an elimination of acute toxicity in the storm drain samples.

Although the majority of tests from ambient sites show no chronic toxicity, Ceriodaphnia reproduction has been reduced 15 times at Mitchell Branch kilometers (MIKs) 0.71, 0.54, 
0.45 , and 0.12 in 1992-93. Ceriodaphnia have been shown to been more sensitive than fathead minnows to ambient water from Mitchell Branch. In each case where fathead minnow toxicity was observed, toxicity to Ceriodaphnia was also observed. As in past years, fathead minnow survival at MIK 1.43 remains low, indicating that this site is an inappropriate reference site for toxicity tests. It remains our hypothesis that the low survival is due to a naturally occurring pathogen, rather than to anthropogenic effects.

\section{Bioaccumulation Studies}

Mercury and polychlorinated biphenyls (PCBs) in fish and clams at sites near the K-25 Site were higher than levels found in fish and clams at two reference streams. Mercury bioaccumulation was observed in fish in Mitchell Branch and nearby sites on Poplar Creek. Mercury concentrations did not exceed the U.S. Department of Agriculture Food and Drug Administration (FDA) limit (1 $\mu \mathrm{g} / \mathrm{g})$, but some fish did exceed more conservative screening thresholds (e.g., preliminary guidance value, $0.42 \mu \mathrm{g} / \mathrm{g}$ ). Experiments using caged and resident minnows suggests that the mercury contamination in Mitchell Branch fish arises from a source within that watershed, rather than being a consequence of contaminated fish immigrating from nearby Poplar Creek.

PCB concentrations were high in fish from two localized aquatic habitats at the K-25 Site (Mitchell Branch, K-1007-P1), but were much lower in fish from Poplar Creek in the vicinity of discharges from these sites. PCB screening of largemouth bass in the ponded tributaries at the K-25 site revealed significant contamination in fish from the K-1007-P1 pond, where the average concentration was $16 \mu \mathrm{g} / \mathrm{g}$. PCB concentrations in caged clams that sampled waterborne PCBs for a fixed time interval were used to infer relative fluxes of PCBs from specific sources. Channel catfish from Poplar Creek continue to contain PCB concentrations similar to other sites in the Clinch River/Watts Bar system, which has resulted in the present fish consumption advisory posted by the Tennessee Department of Environment and Conservation (TDEC).

Metals screening of fish from lower Poplar Creek, Mitchell Branch, and the pond sites revealed little evidence of this form of contamination. Concentrations were either below detection limits or not substantially higher than reference values. Screening for organics other than PCBs in caged clams detected only traces of other organic compounds at very low concentrations, in most cases below the quantification limit of the analytical method. 
Future studies will focus on documenting changes in mercury and PCB contamination in fish over time, improving estimates of the importance of K-25 PCB inputs to Poplar Creek relative to other sources, and assisting in locating the specific sources of PCB contamination at the K-25 Site.

Waterfowl were censused weekly at 13 locations on the K-25 Site. Because very low levels of PCBs and other contaminants occur in geese at the K-25 Site, and sufficient data have been collected to begin modeling of the Canada goose population, the census will be reduced to four sites: Oak Ridge National Laboratory (ORNL), the K-25 Site, the Y-12 Plant, and Melton Hill Dam. Contaminant levels will continue to be monitored by collecting geese and other waterfowl annually for radiological and nonradiological analyses. Where contaminants are known to exist (e.g., K-1007-B and K-901A ponds) additional samples will be taken and analyzed.

Twelve raccoons were trapped near Poplar Creek downstream of the K-25 Site in 1993. Fat and hair samples have been submitted for contaminant analyses.

Ten gizzard shad were collected from the K-1007-P1 pond and from Poplar Creek (near Mitchell Branch) for whole body contaminant analysis. Aliquots from homogenized samples were submitted for analysis of metals and PCBs.

\section{Fish Health Studies}

In all years (1988-1992) the integrated health responses (detoxification enzyme induction, organ dysfunction histopathology, overall health or condition, and nutritional or feeding status) for redbreast sunfish from Mitchell Branch were statistically distinct from those of sunfish collected from three reference sites, thus indicating that sunfish in Mitchell Branch ar in an unhealthy state. Although the difference in health response between sunfish from Mitchell Branch and the reference sites increased from 1989 to 1991 (suggesting a decline in health), it decreased in 1992 (suggesting an improvement in health). Dechlorination of the storm drain effluents may have accounted for part of this improvement. It was evident from the fish health response analysis that there was no consistent pattern among years in the importance of variables relative to intra-year site discrimination. This pattern suggests that fish health is influenced primarily by episodic events that occur in the system and that the primary stressors for these events may not be the same across time. 
Length-frequency distributions and growth analyses of redbreast sunfish have improved over time. The 1992 distribution of sizes was considered balanced and was similar to the size distribution of sunfish found in the reference stream, Paint Rock Creek. By 1992 there was also no significant difference in total length at capture (growth) between Mitchell Branch and the reference stream for any age group.

Redbreast sunfish in Mitchell Branch are reproductively competent, but are spending an abnormally high amount of resources on gamete production compared with fish from the reference stream. This enhanced gamete production may be a stress response to xenobiotics in the diet or water, a result of nutrient enrichment, the consequence of elevated temperatures, the result of lessened competition, or some combination of these or other factors.

Medaka-embryo tests were used to evaluate the effect of water from several sites along Poplar Creek and two sites in Mitchell Branch on fish developmental processes. In three of the four tests conducted during 1993 “94, medaka survival was significantly reduced in wateer from lower Mitchell Branch (MIK 0.12) compared with water from upper Mitchell Branch (MIK 1.43). The results of tests conducted on water from Poplar Creek were variable and suggest additional contaminant sources upstream of the K-25 Site and the ORR. Medaka studies in Mitchell Branch will be expanded to include additional reaches of stream closer to potential contaminant sources in Mitchell Branch (e.g., storm drains).

\section{Population and Community Studies}

The benthic macroinvertebrate community of Mitchell Branch within the main boundary of the K-25 Site continued to indicate the presence of poor water quality. Data collected through April 1993 showed a depression in total and EPT ${ }^{*}$ richness from MIK 0.86 downstream to MIK 0.45 when compared with the reference site. Sites below MIK 1.43 were characterized by substantial fluctuations in density, total richness, and EPT richness between sampling periods. In contrast, the reference site was characterized by a relatively stable and diverse macroinvertebrate community that exhibited small fluctuations in sample parameters. Changes in EPT richness and total richness after 1989 indicate some recovery at all four

\footnotetext{
Ephemeroptera, Plecoptera, and Tricoptera.
} 
downstream sites. The appearance of pollution-intolerant groups, such as mayflies and stoneflies, in 1990 was also indicative of improved conditions. The period of greatest ecological change coincided closely with an improvement in water quality that was documented by ambient toxicity tests after 1988 . Because recovery began prior to any significant operational changes at the K-25 Site, and soon after the end of a drought, the improvements may have been caused by increased dilution resulting from increased stream flows.

Fish population data from Mitchell Branch indicate that improvements in water quality have occurred. There has been an increase in the number of fish present in the fall 1990 through fall 1993 period. Length-frequency distributions indicate more stable populations of fish in Mitchell Branch in 1993 compared with earlier years. However, the species richness is still depressed compared with the reference stream. This lack of species may be due to past extermination and the prevention of recolonization from Poplar Creek and possibly by continued disturbances to the stream.

\section{Future Studies}

Routine sampling will continue for all tasks will the following changes. Because toxicity is rarely present at SD 180, monitoring of this storm drain will be eliminated. Due to the higher sensitivity of Ceriodaphnia and low minnow survival at MIK 1.43, subsequent ambient toxicity tests will be conducted with Ceriodaphnia only. These changes will allow us to concentrate on (1) investigating the source(s) of toxicity to SDs 170 and 190, (2) increasing the frequency of testing at Mitchell Branch sites from four times per year to six, (3) conducting tests of Mitchell Branch and the storm drains concurrently and (4) continuing to investigate potential sources of toxicity from other storm drains. Because no toxicity was observed in water from any site on Poplar Creek and the Clinch River, toxicity tests of these sites will be discontinued. Medaka embryo-larval tests will be expanded to include additional reaches of the stream closer to potential sources of toxic effects. A key objective of the biomonitoring efforts will be to identify and characterize PCB sources in Mitchell Branch and the $\mathrm{K}-1007$ ponds. In addition to fish sampling, caged clams will be used to help evaluate these sources. 


\section{INTRODUCTION \\ R. L. Hinzman and L. A. Kszos}

On September 11, 1986, a modified National Pollutant Discharge Elimination System (NPDES) permit was issued for the Oak Ridge Gaseous Diffusion Plant (ORGDP; now referred to as the Oak Ridge K-25 Site), a former enriched-uranium production facility currently operated by Martin Marietta Energy Systems, Inc., for the U.S. Department of Energy (DOE). As specified in Part III (L) of the permit, a plan for the biological monitoring of the receiving stream (K-1700 stream or Mitchell Branch) was submitted for approval to the U.S. Environmental Protection Agency (EPA) and the Tennessee Department of Environment and Conservation (TDEC) in December 1986. Because it was anticipated that the chemical composition of several effluents would be altered shortly after the permit modifications were issued, the Oak Ridge K-25 Site Biological Monitoring and Abatement Program (BMAP) was implemented in August 1986, before the plan had been formally approved by the regulatory agencies. On October 1, 1992, a renewed NPDES permit was issued for the K-25 Site. A biological monitoring plan was submitted for Mitchell Branch, Poplar Creek, Poplar Creek embayment of the Clinch River, and any unnamed tributaries of these streams as specified in Part III (F) (Kszos et al. 1993).

The initial BMAP for Mitchell Branch was developed to meet two major objectives. First, studies were designed to provide data sufficient to determine whether the interim effluent limits established for the K-25 Site protect and maintain the use of Mitchell Branch for growth and propagation of fish and other aquatic life. A second major objective was to document the effects on stream biota resulting from construction and operation of major new pollution abatement facilities, including the Central Neutralization Facility (CNF) and the Toxic Substances Control Act (TSCA) incinerator. The ecological effects of remedial actions (e.g., closure of the K-1407-B and K-1407-C holding ponds) can also be evaluated by this monitoring program.

The initial BMAP was modified based on results of the biological monitoring conducted since 1986 and discussion with the TDEC on November 12, 1992. The current objectives of BMAP place more emphasis on temporal than spatial trends, while continuing to identify and investigate contaminant sources associated with observed adverse effects. This change places 
more emphasis on monitoring recovery through time in order to assess the effects (and effectiveness) of remedial actions.

The effluents discharged to Mitchell Branch are chemically complex and contain various trace metals, organic chemicals, neutral salts, and radionuclides (Sect. 2.2). Moreover, the composition of these effluents will change as various pollution abatement measures are implemented over the next several years. Although many contaminant inputs to the stream originate primarily as point sources from existing plant operations, area or non-point sources such as the classified burial grounds cannot be eliminated as potential sources of contaminants. An integrated approach to biological monitoring was developed to address this complexity. The Mitchell Branch BMAP consists of four major tasks: (1) toxicity monitoring, (2) bioaccumulation monitoring, (3) assessment of fish health and (4) instream monitoring of biological communities (e.g., benthic macroinvertebrates and fish). 


\section{DESCRIPTION OF STUDY AREA}

R. L. Hinzman and W. K. Roy

Mitchell Branch is a small stream located near the northeast boundary of the Oak Ridge K-25 Site (Figs. 2.1 and 2.2). The stream has a drainage area of $1.78 \mathrm{~km}^{2}$. Mitchell Branch flows only $1.5 \mathrm{~km}$ from its headwaters to its mouth, where it drains into Poplar Creek about $150 \mathrm{~m}$ downstream of the Blair Road bridge. The confluence of the two streams is about $1.5 \mathrm{~km}$ below the mouth of East Fork Poplar Creek (EFPC) and $7 \mathrm{~km}$ above the confluence of Poplar Creek with the Clinch River (Fig. 2.1).

Poplar Creek, which has a drainage area of $352 \mathrm{~km}^{2}$, originates northeast of Oliver Springs, Tennessee, on the Cumberland Plateau (Figs. 2.1 and 2.3). The general direction of streamflow of Poplar Creek is southwesterly, entering the DOE Oak Ridge Reservation (ORR) upstream of the K-25 Site, and then flowing for a distance of $10 \mathrm{~km}$ through the plant area before entering the Clinch River near Clinch River kilometer (CRK) 19.3. EFPC, a major tributary of Poplar Creek, originates from springs on the northwest slope of Chestnut Ridge

within the boundaries of the Oak Ridge Y-12 Plant. Streamflow is controlled by Lake Reality, a 1.0-ha settling pond located $\sim 1.5 \mathrm{~km}$ below the spring. The creek flows for $\sim 24 \mathrm{~km}$ before joining the West Fork at Poplar Creek kilometer (PCK) 8.8.

\subsection{GEOHYDROLOGY ( $R$. L. Hinzman)}

\subsubsection{Mitchell Branch}

Mitchell Branch originates near the base of a small knoll southwest of McKinney Ridge. The knoll is underlain by the Conasauga Group, which consists of a calcareous shale interbedded with thinner layers of limestone and siltstone (DOE 1979). Streams such as Mitchell Branch, which are underlain by shale and sandstone, have a smaller low-flow discharge and greater range in flow than streams underlain by carbonate rocks such as Knox Dolomite (McMaster 1967).

Periods of zero discharge sometimes occur in portions of Mitchell Branch just upstream of the BMAP sampling site at Mitchell Branch kilometer (MIK) 0.86 [J. G. Smith, Environmental Sciences Division (ESD), Oak Ridge National Laboratory (ORNL), personal observation]. Periods of zero discharge are also characteristic of the upper reaches of Melton 


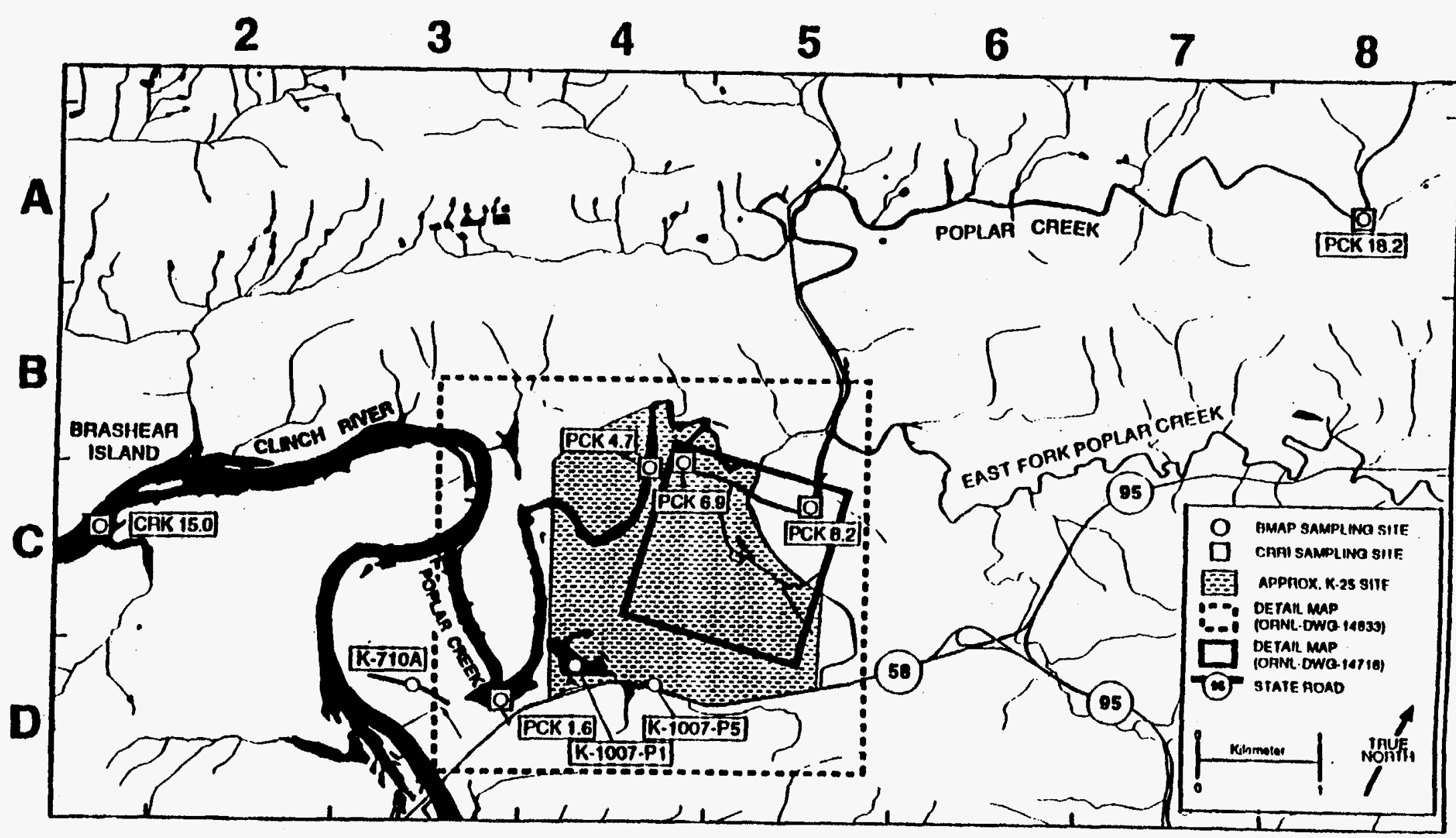

Fig. 2.1. Map of the Oak Ridge K-25 Site area showing the location of sampling sites on Poplar Creek. The drawing is based on a Geographic Information System data base of the 1969 S-15A map of the Oak Ridge, Tennessee, area. The area delineated as "detail map" is shown in Fig. 2.2. BMAP = Biological Monitoring and Abatement Program; CRRI = Clinch River Remedial Investigation; PCK = Poplar Creek kilometer; and CRK = Clinch River kilometer. 


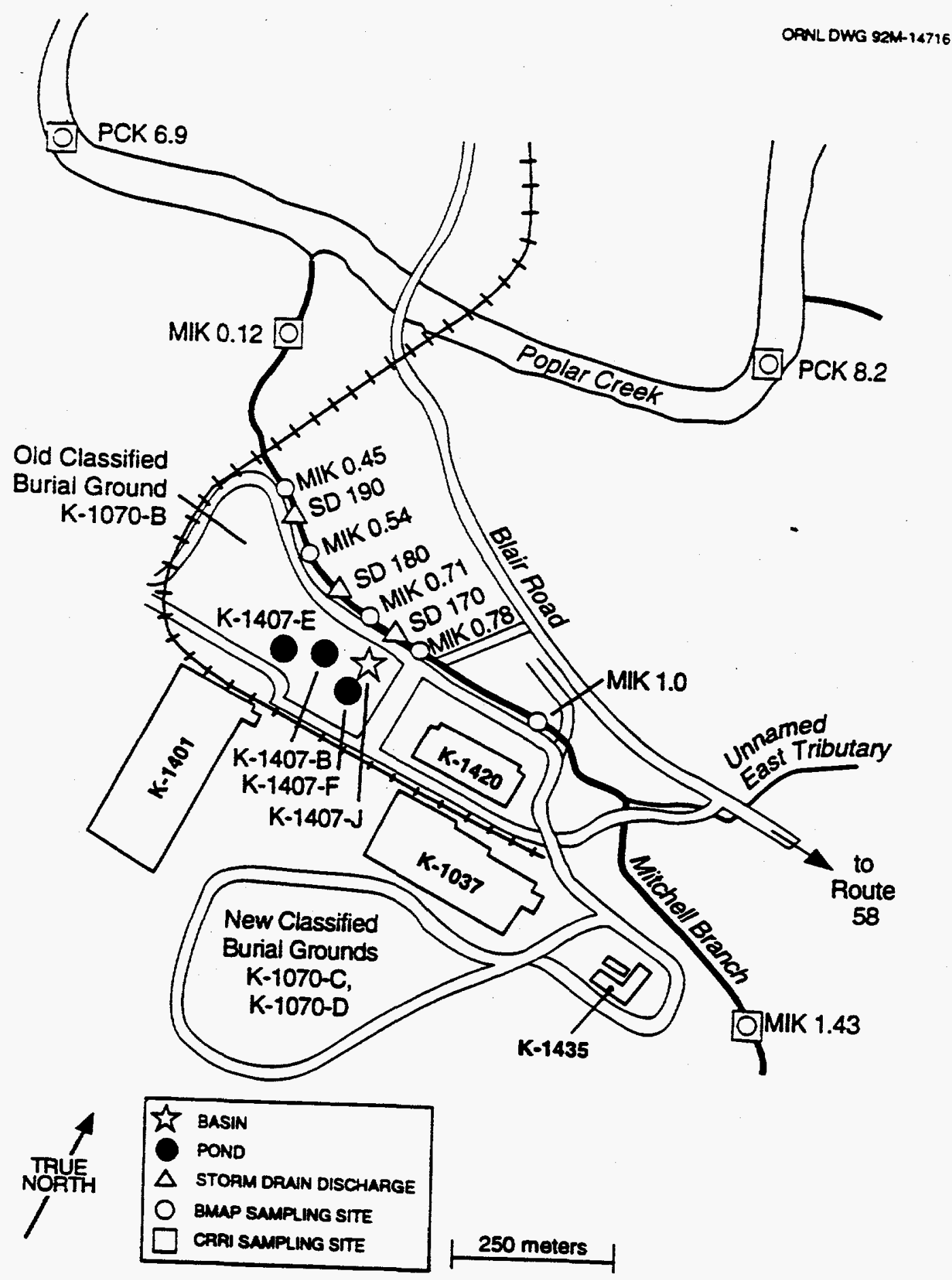

Fig. 2.2. Map of Mitchell Branch and a portion of the Oak Ridge K-25 Site showing the locations of biological monitoring sites $(O)$ in relation to selected storm drains $(\Delta)$ and the K-1407-E/F ponds and the K-1407-J basin, which replaced the K-1407-B pond on November 1, 1988. BMAP = Biological Monitoring and Abatement Program; CRRI = Clinch River Remedial Investigation; MIK = Mitchell Branch kilometer; PCK = Poplar Creek kilometer and $\mathrm{SD}=$ storm drain. 


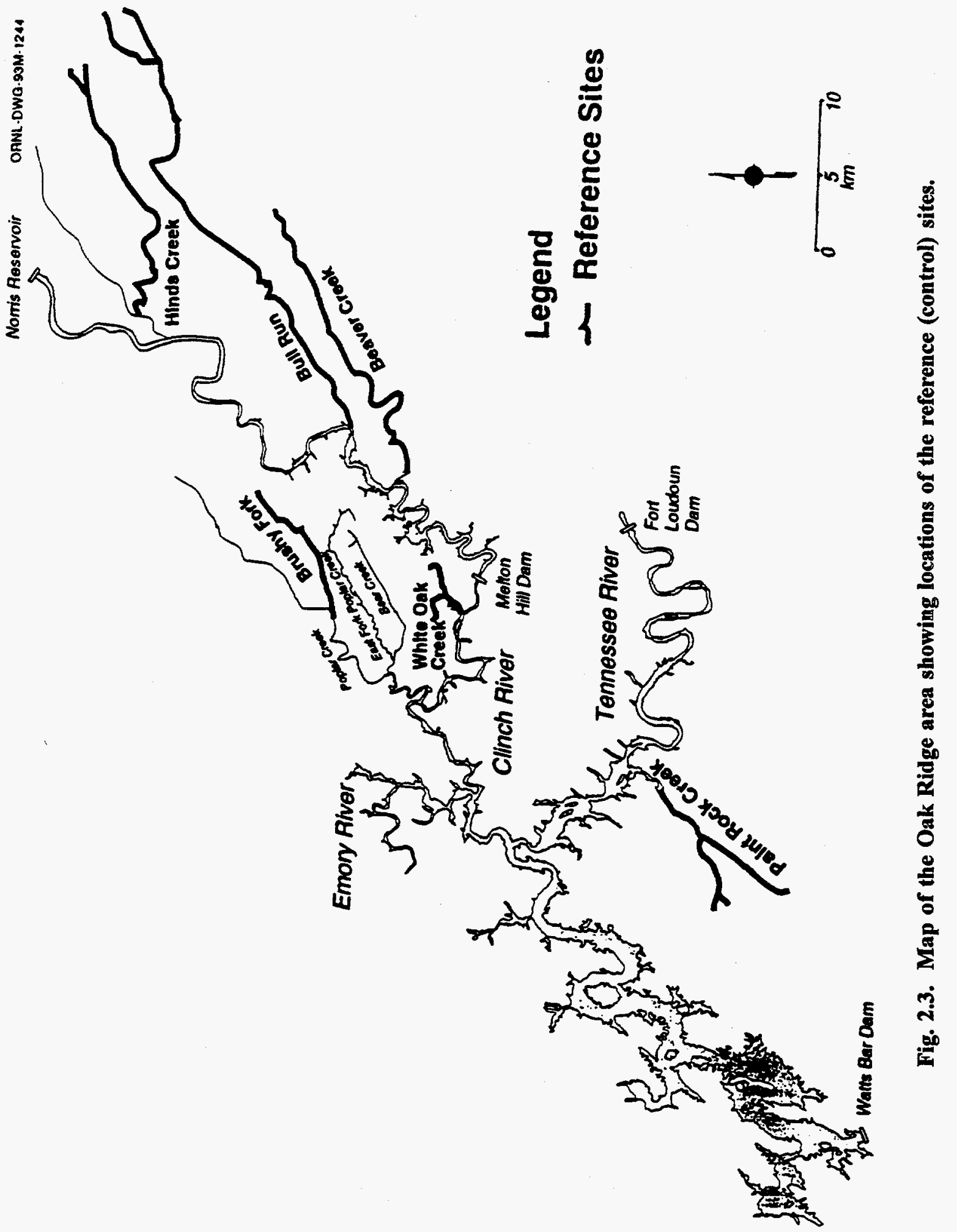


Branch near ORNL (Loar 1990, Table 2.1 in Smith et al. 1994), a small stream that is also underlain predominantly by shale and sandstone (Table 10 in McMaster 1967).

Discharges from the Oak Ridge K-25 Site augment the flow of Mitchell Branch downstream of MIK 0.78. Once-through cooling water and process water account for $<10 \%$ of the base streamflow at monitoring station K-1700 on lower Mitchell Branch at MIK 0.12. Surface run-off and groundwater probably account for most of the remaining flow. Based on these estimates, about $10 \%$ of the flow in lower Mitchell Branch can be attributed to discharges from the Oak Ridge K-25 Site (J. A. Kovacs, Environmental Management Division, personnel communication, 1994). However, in years of below-normal precipitation and minimal runoff, such as $1985-87$, nearly $100 \%$ of the flow in the stream could be plant effluent.

Mitchell Branch has a relatively low temporal variability in discharge volume compared with streams without flow augmentation (Table 2.1 in Smith et al. 1994). The variability in discharge in Mitchell Branch was higher than in EFPC at East Fork Poplar Creek kilometer (EFK) 5.3 , where flow is augmented by $\sim 50 \%$ in dry years. The effect of flow augmentation may be beneficial to some biota by reducing dewatering and thus minimizing the loss of habitat. For example, Horowitz (1978) found that greater numbers of fish species occurred in streams where flow was more constant. However, increased flow stability can reduce environmental heterogeneity (i.e., habitat diversity) which can adversely affect species richness and/or diversity.

Annual precipitation was $151.8 \mathrm{~cm}$ in $1990,152.8 \mathrm{~cm}$ in $1991,111.2 \mathrm{~cm}$ in 1992, and $124.5 \mathrm{~cm}$ in $1993(109 \%, 111 \%, 81 \%$, and $91 \%$ of normal respectively). There were four major storms ( $>5 \mathrm{~cm}$ in $24 \mathrm{~h}$ ) in 1990, six in 1991, zero in 1992, and one in 1993. Mean annual flow (MAF) in Mitchell Branch was $35.5 \mathrm{~L} / \mathrm{s}$ in 1990, 31.5 L/s in 1991, $25.8 \mathrm{~L} / \mathrm{s}$ in 1992, and 19.1 L/s (values for April through December, 1993, only) in 1993.

The number of days of zero discharge in upper Melton Branch also provides a relative measure of ecologically meaningful differences in the hydrographs of the past 4 years. For example, no flow was recorded for $39 \mathrm{~d}$ in 1990, $51 \mathrm{~d}$ in 1991, 42 days in 1992, and $137 \mathrm{~d}$ in 1993 (Table 2.1). The number of days with zero discharge in 1993 (137 d) approached those seen during the drought period of 1986-1988. These data indicate that any adverse ecological effects resulting from reduced streamflow may have been greater in 1993 because of belownormal precipitation in 1992 and 1993. 
Table 2.1. Number of days of zero discharge (number of consecutive days in parentheses) in upper Melton Branch at kilometer 1.93 (USGS gaging station 03537100)

\begin{tabular}{llllllllll}
\hline & May & June & July & August & September & October & November & December & Total \\
\hline 1985 & 0 & $4(2)$ & $8(6)$ & 0 & $2(2)$ & 0 & 0 & 0 & 14 \\
1986 & 0 & $10(10)$ & $15(15)$ & $31(31)$ & $27(24)$ & $20(12)$ & 0 & 0 & 103 \\
1987 & 0 & $11(8)$ & $21(19)$ & $21(31)$ & $30(30)$ & $31(31)$ & $30(30)$ & $18(14)$ & 172 \\
1988 & $2(2)$ & $30(30)$ & $21(12)$ & $30(26)$ & $25(11)$ & $31(31)$ & $3(3)$ & & 142 \\
1989 & 0 & 0 & $1(1)$ & $21(17)$ & $7(5)$ & 0 & 0 & 0 & 29 \\
1990 & 0 & $5(5)$ & $5(3)$ & $3(3)$ & $22(11)$ & $4(3)$ & 0 & 0 & 39 \\
1991 & 0 & 0 & $3(2)$ & $16(8)$ & $26(16)$ & $6(4)$ & 0 & 0 & 51 \\
1992 & 0 & $4(4)$ & $1(1)$ & $7(3)$ & $27(16)$ & $3(3)$ & 0 & 0 & 42 \\
1993 & 0 & $13(7)$ & $28(13)$ & $28(18)$ & $29(26)$ & $28(21)$ & $11(7)$ & 0 & 137 \\
\hline
\end{tabular}

Source: Lowery et al. $(1986,1987,1988,1989,1990)$ and USGS provisional data for 1990, 1991, 1992, and 1993 (L. D. Voorhees, ORNL, unpublished data). Full citations available in Chapter 8, this document.

\subsubsection{Poplar Creek}

Poplar Creek is the largest tributary of the Clinch River between Melton Hill Dam and the northwest boundary of ORR. It has an average annual discharge that is approximately ten times greater than the combined discharges of other tributaries in this $21-\mathrm{km}$ reach of the river (Loar et al. 1981). It flows from Poplar Creek Valley, which is underlain by the Conasauga shale, through a gap in Black Oak Ridge, which is underlain by the Knox Formation, and enters the Clinch River southwest of the Oak Ridge K-25 Site. With the exception of the silty shale and siltstone-sandstone members of the Rome Foundation adjacent to Route 58, southeast of the plant, most of the K-25 Site is underlain by Chickamauga Limestone (DOE 1979).

Poplar Creek exhibits seasonal fluctuations in discharge that, in general, reflect precipitation and runoff patterns typical of this region of East Tennessee. Maximum precipitation is in the winter (December-February), when $\sim 31 \%$ of the annual precipitation occurs; the wettest months being February and March (NOAA 1990). Maximum runoff is also likely to occur in January, February, or March, when rainfall is normally high and soil moisture and groundwater storage are highest (McMaster 1967). Discharge in Poplar Creek has historically been highest during the winter months and lowest in late summer, when rainfall is normally low and runoff is minimal (Fig. 2.4 in Smith et al. 1994). Water levels in lower Poplar Creek are also influenced by the operation of two Tennessee Valley Authority (TVA) dams: Melton Hill Dam at CRK 37.2 (completed in 1963) upstream of the confluence and Watts Bar Dam located at Tennessee River kilometer (TRK) 852 (completed in 1942) 
downstream of the confluence. Dam operations affect the magnitude and frequency of water level fluctuations in the Poplar Creek embayment as they influence the water level at the Clinch River, but they also influence stream velocities and flow direction in the lower reaches of Poplar Creek.

\subsection{WATER QUALITY}

Water quality of Mitchell Branch is influenced by the geology of the drainage basin (Sect. 2.1), point source discharges of effluents that enter the stream via storm drains, and leachate from waste disposal sites. The following characterizations of water quality are preceded by general descriptions of the sources of effluents discharged by the Oak Ridge K-25 Site. The characterizations of water quality are based on data from monitoring station K-1700 (Sect. 2.2.2.1), effluent data from the K-1407-J basin (Sect. 2.2.2.2), and BMAPrelated measurements of water temperatures (Sect. 2.2.3). Water quality characterizations of Mitchell Branch associated with toxicity testing are given in Sect. 3.2.3.1.

\subsubsection{Description of the Oak Ridge K-25 Site Discharges}

\subsubsection{Mitchell Branch}

Point-source discharges to Mitchell Branch from current Oak Ridge K-25 Site operations are generally from storm drain effluents. Prior to October 1988, wastes from the uranium recovery facility, the metals cleaning facility, the chemical process development facility, the steam plant, and the coal yard were neutralized in a $113,500-\mathrm{L}$ vat prior to discharge into the K-1407-B pond. Metal hydroxides were allowed to settle to the bottom of the pond, and the supernatant was conveyed, via a 1.6-km long ditch, to Mitchell Branch (Fig. 2.1).

Closure of the K-1407-B pond began on October 31,1988 , under the Resource Conservation and Recovery Act. The pond now receives rainwater and surface runoff, which is pumped to the CNF for treatment before being discharged to Poplar Creek. K-1407 B Pond is now in the process of being closed. The pond is being backfilled with an engineered rock fill and overlain with an engineered soil cover.

Many storm drains (SD) enter Mitchell Branch. Although some of these drains contribute only runoff water from roofs and parking lots to the stream during rainfall events, others may also convey groundwater. In the new NPDES permit, storm drains are classified according to their source and potential for contamination. Six storm drains are classified as Category IV 
outfalls (those outfalls that pose the risk of conveying pollutants that could be released to the waters of the state). Of these six, three discharge to Mitchell Branch through SDs 170, 180, or 190. The remaining Category IV outfalls discharge to Poplar Creek through the K-1007 ponds. There are 34 Category III outfalls that enter Mitchell Branch or Poplar Creek, 29 Category II and 66 Category I outfalls that enter Mitchell Branch, Poplar Creek, or Watts Bar Reservoir.

In March 1991, following verbal approval from TDEC, discharge from the K-1407-E/F ponds was ceased as a routine operation. Instead, the coal pile and steam plant wastewaters were routed through the CNF for additional treatment and discharged through the $\mathrm{K}-1407-\mathrm{J}$ basins to Poplar Creek (Kornegay et al. 1993).

Several abatement activities over the sampling period may have affected water quality in Mitchell Branch (Table 2.2). Chlorinated discharges to SD 190 from K-1401 were removed in 1992. In 1992, the K-25 Site began treating runoff from the Steam Plant coal pile at CNF. Prior to that time, acidic runoff was discharged to Mitchell Branch via SD 170. The coal pile was removed in winter 1993 and the area was reseeded. The Powerhouse coal pile was limed in summer 1993 to reduce acidic runoff through SD 992 . This coal pile is scheduled to be reclaimed (capped) by September 1994. Chlorinated discharges to storm drains were eliminated by October 1993. The process primarily involved discharges to SDs $100,124,170$, 180, and 190. Discharges were dechlorinated slowly, one by one, during 1993. A best management plan (BMP) was developed for the fire training facility in early 1993 that reduced the amount of petroleum products and water being discharged through SD 190. In May 1993, a procedure was initiated to drain a dike containing 600,000 gallons of diesel fuel at the Steam Plant, resulting in the elimination of discharges of small amounts of fiesel fuel to SD 170 .

The K-25 Site began collecting and treating effluent from the SW-31 Seep in January 1994, reducing discharges of organic compounds (especially trichloroethylene) through SDs 170 and 180. A BMP was developed for the K-1414 garage in March 1994 that eliminated almost all oil spills and discharges from that facility to SD 180. Erosion control measures were initiated in May 1994 at the soil disposal area north of Mitchell Branch across from SD 190.

\subsubsection{Poplar Creek}

The CNF (Building K-1407-H) went on-line in October 1987. The CNF can treat waste streams that require only neutralization and chemical precipitation. Filtration is also used at 
Table 2.2. Partial list of events that may have affected water quality in Mitchell Branch, 1987 through 1994

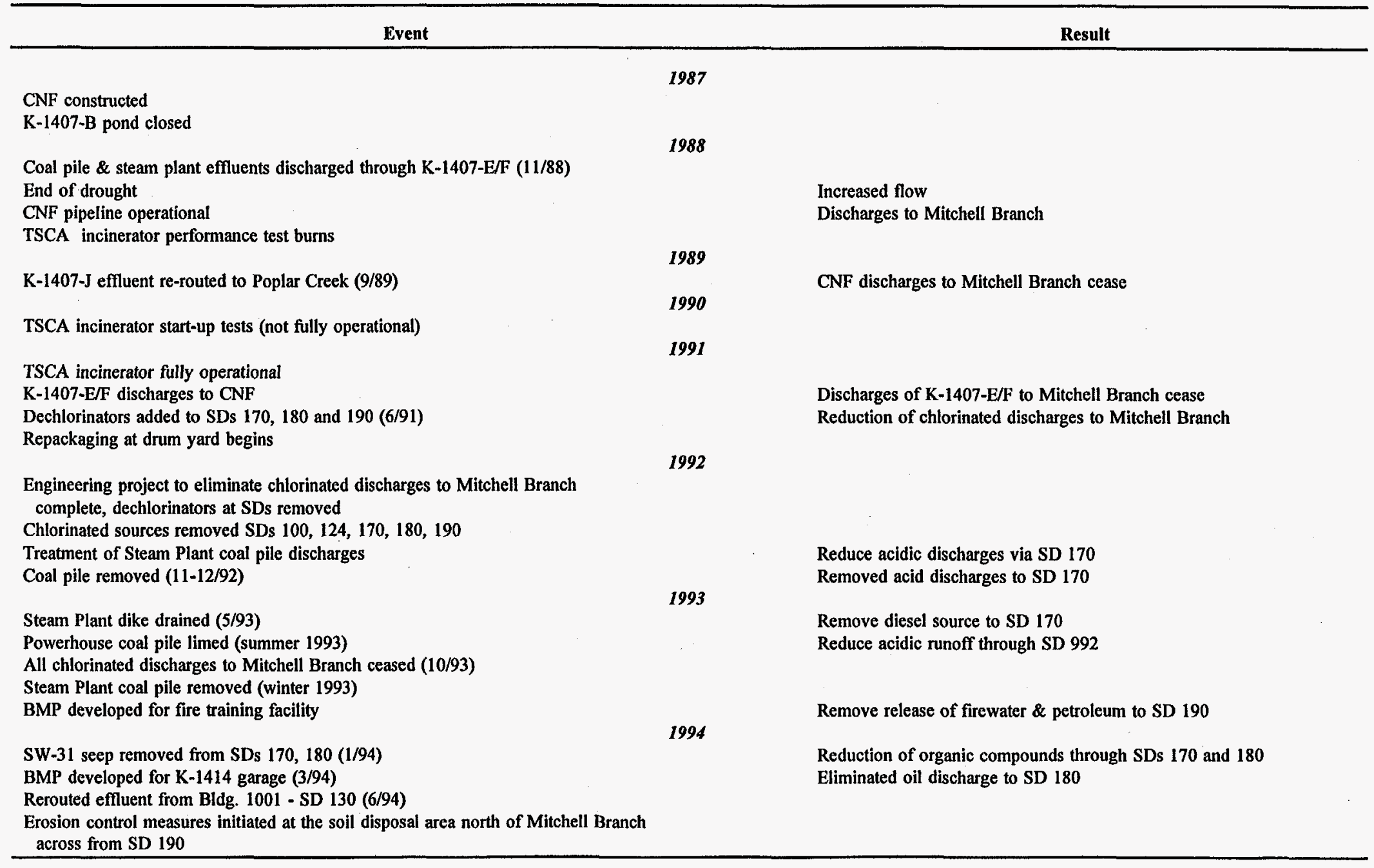

Note: $\mathrm{CNF}=$ Central Neutralization Facility. $\mathrm{TSCA}=$ Toxic Substances Control Act. $\mathrm{SD}=$ storm drain. $\mathrm{BMP}=$ Best Management Plan. 
the CNF for additional solids removal. At the CNF, both hazardous and nonhazardous waste streams are treated. The primary hazardous waste stream is wastewater from the TSCA incinerator. The principal nonhazardous waste stream is wastewater generated at the K-1501 steam plant. The waste streams from the TSCA incinerator and the steam plant contribute $>95 \%$ of the influent to the CNF. In addition to these primary waste streams, the CNF treats miscellaneous waste streams which meet the waste acceptance criteria for the CNF. The effluent from the CNF is currently discharged into Poplar Creek at kilometer 5.1.

\subsubsection{NPDES Monitoring}

\subsubsection{Mitchell Branch}

The following characterization of water quality in Mitchell Branch is based on routine monitoring of parameters at station K-1700. This site is located on lower Mitchell Branch (MIK 0.12) downstream of all point-source and most area-source discharges (Figs. 2.1 and 2.2).

From 1990 through 1993, water quality at MIK 0.12 was characterized by (1) moderate levels of dissolved solids and occasionally high levels of suspended solids, (2) relatively low levels of nutrients, (3) elevated levels of some metals (e.g., aluminum and iron) and some organics, and (4) high temperatures (discussed in Sect. 2.2.3). Mean concentrations for substances in water at K-1700 above detection limits are summarized in Table A.1. The effects of elevated concentrations of these substances on the aquatic community cannot be adequately addressed because of the uncertainty of magnitude and duration of the substances in the stream. Water samples were often one-time grab samples and therefore may not have been collected during the peak of a potential release.

Mean dissolved solids concentrations at K-1700 have decreased in the 1990-1993 sampling period. However, maximum recorded values exceeded the maximum drinking water contaminant level in 1990, 1991, and 1992 (Table A.1).

Concentrations of nitrogen in Mitchell Branch are low, whereas concentrations of phosphorus are high. Even though concentrations of nitrate nitrogen were higher than background ( $0.1 \mathrm{mg} / \mathrm{L}$; Boyle et al. 1982, Table 3.16), they averaged less than $1 \mathrm{mg} / \mathrm{L}$ and never exceeded $6 \mathrm{mg} / \mathrm{L}$ at MIK 0.12 (Appendix A, Tables A.1-A.4). Phosphorus is not monitored in Mitchell Branch, but water from the K-1407-J basin had a mean phosphorus 
concentration of $1.5 \mathrm{mg} / \mathrm{L}$ in 1990 and $<3.1 \mathrm{mg} / \mathrm{L}$ in 1991 , with a maximum recorded value of $3.7 \mathrm{mg} / \mathrm{L}$ in 1989 (Appendix A, Table A.3).

Many of the metals (Appendix A, Tables A.1-A.5) in Mitchell Branch exceeded concentrations that are typical of small, relatively undisturbed streams on the ORR (Boyle et al. 1982, Tables 3.16 and 4.16). Only manganese had a mean concentration above the reference value at K-1700 (Table A.1). Aluminum, iron, and manganese had maximum values that exceeded the reference limits at K-1700 (Tables A.I and A.5). Of the organics measured in Mitchell Branch, all were above detection limits at least some of the time (Table A.1). Except for the decrease in dissolved solids that has occurred in since 1990, the water quality of Mitchell Branch has remained relatively constant over the last 4 years (1990-93).

\subsubsection{Discharges to Poplar Creek}

Effluent from the K-1407-J basin was characterized by high concentrations of dissolved solids with mean values exceeding reference values from 1990-1992. (Table A.3).

Concentrations of nitrate, phosphorous, and sulfate were all elevated in K-1407-J. Although the mean value for nitrate in 1991 was lower than the reference, the maximum value exceeded the reference value (Table A.3). The mean concentration of phosphorous in 1990 was 1.5 , and the maximum concentration was $15.0 \mathrm{mg} / \mathrm{L}$. The mean concentration of sulfate was higher than $250 \mathrm{mg} / \mathrm{L}$ in 1991 and 1992; maximum values in these 2 years were 1500 and $1000 \mathrm{mg} / \mathrm{L}$ respectively.

Concentrations of all metals that were monitored from 1990-93 were elevated at some time during this period, and most had mean values above the detection limits (Table A.3). However, only manganese had mean concentrations above the reference values (1991, Table A.3).

Although most of the organics that were monitored had mean values at or below detection limits, many were detectable at some time during the sampling period (Table A.3).

\subsubsection{Temperature (W. K. Roy)}

Ryan Tempmentor digital temperature recorders were deployed on April 9, 1987, in Mitchell Branch at MIK 0.50 immediately below the outfall of SD 190 and in Grassy Creek, a nearby drainage with similar geology (Sect. 2.1; McMaster 1967, Table 10). Temperature values were obtained every $20 \mathrm{~min}$. until July 1, 1987, and every $60 \mathrm{~min}$. thereafter. The 
record is incomplete due to periodic equipment problems or recorders being out of water (either inadvertently or for data retrieval).

Grassy Creek kilometer (GCK) 2.4 site was dropped as a reference site in April 1991, in part due to its intermittent nature. It was also becoming increasingly difficult to access this site because it was situated within the boundaries of the newly created Surface Danger Zone for the Central Training Facility firing range on Bear Creek Road. Furthermore, the associated construction activity upstream of GCK 2.4 was causing increasing siltation at this site (M. G. Ryon, pers. comm., May 26, 1994). The site was replaced with one on Scarboro Creek, a reference stream located approximately $16 \mathrm{~km}$ northeast of Grassy Creek, in Anderson County. Temperature monitoring was initiated at Scarboro Creek kilometer (SCK) 2.2 on October 28, 1991.

Through the period of record, Mitchell Branch temperatures were high relative to unimpacted ORR streams. Mean weekly temperatures in Mitchell Branch sometimes exceeded $25^{\circ} \mathrm{C}$ but were generally below $20^{\circ} \mathrm{C}$ in Grassy Creek and always below $20^{\circ} \mathrm{C}$ in Scarboro Creek (Fig 2.4). Temperatures in Mitchell Branch averaged $\sim 4$ to $8^{\circ} \mathrm{C}$ higher than in Grassy Creek, and up to $7^{\circ} \mathrm{C}$ higher than in Scarboro Creek. Winter water temperatures in Scarboro Creek more closely approximate those found in Mitchell Branch than do those in Grassy Creek. In fact, mean monthly temperatures in Scarboro Creek were slightly higher than in Mitchell Branch during January, February, and March of 1994. Summer water temperatures, however, are often much higher in Mitchell Branch than in the reference streams. The maximum temperature at MIK 0.50 in June 1987 was $19^{\circ} \mathrm{C}$ higher than that at GCK 2.4 , and in August 1992 it surpassed the SCK 2.2 maximum temperature by more than $25^{\circ} \mathrm{C}$ (Table A.6).

The temperature of Mitchell Branch is influenced strongly by warm cooling-water discharges (via storm drains) and the discharge of effluent from open retention ponds (K-1407-B prior to October 1988 and $\mathrm{K}-1407-\mathrm{E} / \mathrm{F}$ after this period) prior to discharge just $130 \mathrm{~m}$ above the monitoring station at MIK 0.50. Furthermore, except for the headwaters, there is little canopy cover above MIK 0.50 to help moderate temperatures. 


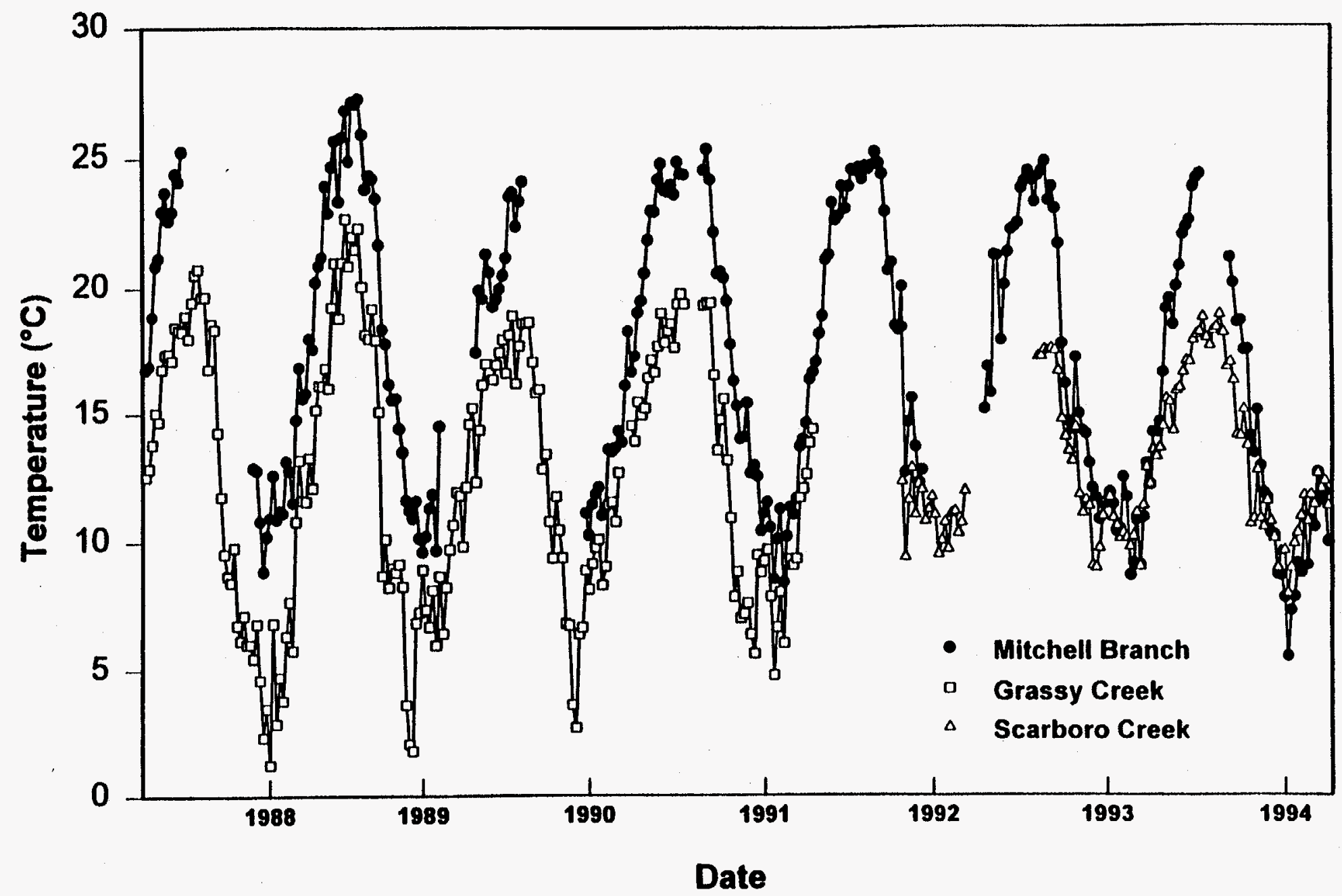

Fig. 2.4. Weekly mean temperatures for Mitchell Branch kilometer 0.50, 1987-1994, Grassy Creek kilometer 2.4, 1987-1991, and Scarboro Creek kilometer 2.2, 1991-1994. Temperature record is incomplete as a result of equipment failure. 


\subsection{BIOLOGICAL MONITORING SITES ( $R$. L. Hinzman)}

During the initial BMAP study, eight sites on Mitchell Branch (Figs. 2.1 and 2.2 and Table 2.3 ) were routinely sampled to assess ecological conditions in the stream. Although the upper site (MK 1.43) was the primary reference site, sites on other area streams were also used as reference stations (Fig. 2.3). The lowermost site at MIK 0.12 coincided with the location of the (then NPDES) K-1700 monitoring station. A sampling site for the bioaccumulation task was located at PCK 6.9, downstream of the mouth of Mitchell Branch. Four of the remaining six sites (MIKs $0.78,0.71,0.54$, and 0.45 ) were selected based on the location of the three most significant discharges to Mitchell Branch (SDs 170, 180, and 190); these monitoring sites were located above and below each of the outfalls respectively. The remaining two sites (MIK 0.86 and MIK 1.10) were selected to assess the potential for adverse impacts associated with (1) construction of a storage yard located immediately northeast of Mitchell Branch and (2) minor inputs from several storm drains located further upstream.

Sampling locations for the current BMAP are shown in Figs. 2.1 and 2.2 and are discussed in Table 2.3 and the description for each task. Many of the tasks share Poplar Creek and Clinch River sites with the Clinch River Remedial Investigation (CRRI). Task 1 (Toxicity Monitoring) maintained six sites in Mitchell Branch and added new sites in Poplar Creek and the Clinch River. Task 2a (Contaminant Accumulation in Aquatic Biota) maintained five sites (one each in Mitchell Branch and Clinch River and three in Poplar Creek) and added three new ones: Poplar Creek (one site) and two on unnamed tributaries. Task $2 b$ (Contaminant Accumulation in Terrestrial Biota) will consist of site-wide monitoring, including sites both within and adjacent to the K-25 Site. Task $3 a$ (Assessment of Fish health) maintained a site in Mitchell Branch and added sites in Poplar Creek, Clinch River, and an unnamed tributary. Task 3b (Reproductive Effects) is a new subtask and includes sites in Mitchell Branch, Poplar Creek, and the Clinch River. Task 4a (Instream Monitoring of Benthic Invertebrates) maintained four sites in Mitchell Branch and unnamed tributaries. Task $4 \mathrm{~b}$ (Instream Monitoring of Fish) maintained two sites in Mitchell Branch. 
Table 2.3. Location of the biological monitoring sites on Mitchell Branch, Poplar Creek, and unnamed tributaries

\begin{tabular}{|c|c|c|c|c|c|c|c|c|}
\hline \multirow[b]{2}{*}{ Site } & \multirow[b]{2}{*}{$\begin{array}{l}\text { Toxicity } \\
\text { Monitoring }\end{array}$} & \multicolumn{3}{|c|}{ Bioaccumulation monitoring } & \multicolumn{2}{|c|}{ Assessment of fish health } & \multicolumn{2}{|c|}{ Instream monitoring } \\
\hline & & $\begin{array}{l}\text { Aquatic } \\
\text { biota }\end{array}$ & $\begin{array}{l}\text { Food-chain } \\
\text { effects }^{a}\end{array}$ & Waterfowl ${ }^{b}$ & Bioindicators & $\begin{array}{l}\text { Reproductive } \\
\text { effects }\end{array}$ & $\begin{array}{c}\text { Benthic } \\
\text { invertebrates }\end{array}$ & Fish \\
\hline \multicolumn{9}{|l|}{ Mitchell Branch } \\
\hline MIK 0.12 & $X$ & $\mathrm{X}$ & & & $\mathbf{X}$ & $\mathrm{X}^{b}$ & & \\
\hline MIK 0.45 & $\mathrm{X}$ & & & & & & $X$ & $\mathbf{X}$ \\
\hline MIK 0.54 & $\mathrm{x}$ & & & & & & & \\
\hline MIK 0.71 & $\mathrm{x}$ & & & & & & $X$ & $\mathbf{X}$ \\
\hline MIK 0.78 & $\mathrm{X}$ & & & & & & $\mathbf{X}$ & \\
\hline MIK 1.0 & $X^{e}$ & & & & & & & \\
\hline MIK 1.43 (ref.) & $\mathrm{x}$ & & & & & $\mathbf{x}$ & $X$ & \\
\hline Others (ref.) & $\mathrm{X}^{d}$ & $\mathrm{X}$ & & & $\mathrm{X}^{c, d}$ & $\mathrm{X}^{d}$ & & $\mathbf{X}$ \\
\hline \multicolumn{9}{|l|}{ Poplar Creek } \\
\hline PCK 1.6 & $\mathrm{X}^{d}$ & $\mathrm{X}^{c}$ & & & $\mathrm{X}^{d}$ & $\mathrm{X}^{d}$ & & \\
\hline PCK 4.7 & $\mathrm{X}^{d}$ & & & & & $\mathrm{X}^{d}$ & & \\
\hline PCK 6.9 & $\mathrm{X}^{d}$ & $\mathrm{X}^{\epsilon}$ & & & $\mathrm{X}^{d}$ & $\mathrm{X}^{d}$ & & \\
\hline PCK 8.2 & $\mathrm{X}^{d}$ & $\mathrm{X}^{c}$ & & & $\mathrm{X}^{d}$ & $\mathrm{X}^{d}$ & & \\
\hline PCK 18.2 (ref.) & $\mathrm{X}^{d}$ & $\mathrm{x}$ & & & $\mathrm{x}$ & $\mathrm{x}$ & & \\
\hline \multicolumn{9}{|l|}{ Clinch River } \\
\hline CRK 15.0 & $\mathrm{X}^{d}$ & $\mathrm{X}^{c}$ & & & $\mathrm{X}^{d}$ & $\mathrm{X}^{d}$ & & \\
\hline \multicolumn{9}{|l|}{ Other sites } \\
\hline K-1007 (P1 \& P5) & & $\mathrm{X}$ & & & $\mathbf{X}$ & & & \\
\hline Tributary to K-1007-P5 & & & & & & & $\mathrm{x}$ & \\
\hline Unnamed East Tributary & & & & & & & $\mathbf{x}$ & \\
\hline $\mathrm{K}-710 \mathrm{~A}$ & & $\mathrm{X}$ & & & & & & \\
\hline
\end{tabular}

Note: Reference sites include designation "ref." following kilometer reading. MIK = Mitchell Branch kilometer, PCK = Poplar Creek kilometer, and CRK = Clinch River kilometer.

${ }^{a}$ Task consists of site-wide monitoring (see Sect. 2.2.3).

. ${ }^{b}$ Other sites on Mitchell Branch to be determined after initial tests are completed.

'Site not included in original Biological Monitoring and Abatement Program plan, but added later.

${ }^{d}$ Sites included in Sampling and Analysis Plan (Phase 2). of Clinch River Remedial Investigation (R. B. Cook, et al., unpublished data).

${ }^{\text {e}}$ This sampling site was moved to MIK 0.78 in April 1993 to coincide with benthic macroinvertebrate sampling. 


\title{
3. TOXICITY MONITORING (TASK 1)
}

\author{
L. A. Kszos
}

The toxicity monitoring task for the K-25 Site consists of three subtasks. The first subtask measures the toxicity of effluents as required by the NPDES permit. The second subtask monitors ambient water toxicity of six sites in Mitchell Branch, five sites in Poplar Creek, and one site in the Clinch River. The third subtask measures the toxicity of the three major storm drains that enter Mitchell Branch. The effluent and storm drain toxicity data are presented in Sect. 3.1; the ambient toxicity data are presented in Sect. 3.2.

\subsection{EFFLUENT AND STORM DRAIN TOXICITY}

\subsubsection{Introduction}

The EPA supports the use of aquatic test organisms to determine the chronic toxicity of a test water (Weber et al. 1989). Toxicity monitoring at the K-25 Site uses two tests concurrently to characterize the toxicity of effluents from two outfalls that discharge to Poplar Creek. They are the Cladoceran (Ceriodaphnia dubia) Survival and Reproduction Test (hereinafter referred to as the Ceriodaphnia test) and the Fathead Minnow (Pimephales promelas) Larval Survival and Growth Test (hereinafter referred to as the fathead minnow test, Weber et al. 1989). These two tests are EPA-approved for use in the NPDES program to estimate (1) the chronic toxicity of effluents collected at the end of the discharge pipe and tested with a standard dilution water, (2) the toxicity of receiving water downstream from or within the influence of the outfall and (3) the effects of multiple discharges on the quality of the receiving water (Weber et al. 1989). These tests are also part of the BMAPs at ORNL, the Oak Ridge Y-12 Plant, and the Biological Monitoring Program at the Paducah Gaseous Diffusion Plant.

The Toxicology Laboratory of ESD at ORNL began evaluating the toxicity of effluent from CNF (K-1407-J, Outfall 011) in February 1990. Tests of the K-1203 Treatment Facility (Outfall 005; primarily a sewage treatment facility) began in June 1991, but bimonthly testing was not implemented until after the renewed NPDES permit became final (October 1992). Under the renewed permit, toxicity tests of CNF and K-1203 were conducted bimonthly beginning in November 1992. According to the NPDES permit, the testing frequency can be 
reduced to twice per year if no toxicity is observed for six consecutive tests. Because this was the case at CNF, testing frequency was reduced to twice per year in November 1993.

The three major storm drains that discharge to Mitchell Branch were monitored under the BMAP because (1) they discharge into a reach of Mitchell Branch that is known to be stressed (Smith et al. 1993, 1994); (2) toxicity tests conducted during 1987-89 indicated that these effluents were toxic, and (3) when the pipeline to Poplar Creek was constructed for CNF, the storm drains became the major source of anthropogenic input to Mitchell Branch. During 1990-92, effluent from SDs 170, 180, and 190 was evaluated for toxicity to fathead minnows two or three times each year. As part of the revised BMAP (Kszos et al., 1993) Ceriodaphnia tests of the storm drains have been conducted every other month since April 1993.

\subsubsection{Materials and Methods}

This report includes tests conducted from January 1990 to April 1994. Effluent from K-1407-J (Outfall 011) was evaluated five to six times per year and effluent from K-1203 (Outfall 005) was evaluated twice in 1991, once in 1992, eight times in 1993, and three times in 1994. Effluent from SDs 170, 180, and 190 was evaluated eight times in 1990-92 and six times in 1993-94. Prior to November 1992, tests of CNF were conducted using seven consecutive daily grab samples collected at the NPDES discharge point. Subsequent tests used seven 24-h composite samples as required by the renewed NPDES permit. All tests of K-1203 were conducted using composite samples. All tests of storm drains were conducted using daily grab samples. Samples from CNF and K-1203 were collected by the K-25 Site personnel and delivered according to established chain-of-custody procedures (Kszos et al. 1989). Samples from storm drains were collected by ESD personnel.

Tests with Ceriodaphnia and fathead minnows were typically conducted concurrently following procedures outlined in Weber et al. (1989) and Kszos et al. (1989). These tests are static, renewal tests, meaning that test water is replaced daily for six or seven consecutive days. Animals are fed daily. The fathead minnow test consists of four replicates per test concentration with ten animals per replicate. Each day before the water was replaced, the number of surviving larvae was recorded. At the end of $7 \mathrm{~d}$, the larvae were dried and weighed to obtain an estimate of growth. The Ceriodaphnia test consists of ten replicates per test concentration with one animal per replicate. Each day, the animals were transferred from a beaker containing old test solution and placed in a beaker containing fresh test solution. At 
this time, survival and the number of offspring produced were recorded. A laboratory control consisting of dilute mineral water augmented with trace metals was included with each test. On each day of a test, subsamples of each effluent were routinely analyzed for $\mathrm{pH}$, conductivity, alkalinity, water hardness, and total residual and free chlorine (Kszos et al. 1989). In addition, $\mathrm{pH}$ and dissolved oxygen were measured in 24-h old samples.

For each toxicity test, the no-observed-effect level (NOEL) and the 96-h $\mathrm{LC}_{50}$ were determined using methods described in Weber et al. (1989). The NOEL is the highest concentration of effluent tested that does not reduce fathead minnow survival or growth or Ceriodaphnia survival or reproduction. The $96-\mathrm{h} \mathrm{LC}_{50}$ is the concentration that kills $50 \%$ of the test organisms in 96 hours. In the renewed permit, a NOEL for CNF of $\leq 2.11 \%$ effluent or a $96-\mathrm{h} \mathrm{LC}_{50}$ of $\leq 7.05 \%$ effluent constitutes a violation of levels required by the permit. At $\mathrm{K}-1203$, a NOEL of $\leq 4.2 \%$ effluent or a $96-\mathrm{h} \mathrm{LC}_{50}$ of $\leq 14.6 \%$ effluent constitutes a violation of permit levels. The compliance points were determined by the TDEC and were based upon the dilution of the effluents once they enter Poplar Creek. The results of each test are submitted to the K-25 Site and subsequently submitted to the TDEC. These reports contain daily survival and reproduction information, statistical results, water chemistry for at least three concentrations of effluent, quality assurance information, etc. In the following section, only the NOEL, 96-h $\mathrm{LC}_{50}$, and water chemistry for full-strength effluent are reported. Toxicity tests of the storm drains are not required in the NPDES permit and are conducted only as part of the BMAP.

\subsubsection{Results}

\subsubsection{CNF (K-1407-J, Outfall 011)}

A summary of the NOELs for all toxicity tests conducted from January 1990 to November 1993 are provided in Table 3.1. Results of tests conducted during 1988-1989 are in Kszos (1994). In February 1990 and April 1991, effluent from CNF would have exceeded the NOEL limit in the renewed permit (2.11\%) if it had been in effect. However, under the previous permit, which was in effect at that time, the exceedences were not violations of any toxicity limit. Since the renewed permit became effective, effluent from the CNF has not exceeded the permit limits. Thus, in November 1993, the test frequency was reduced to twice per year. 
Table 3.1. Toxicity test results for the Central Neutralization Facility (CNF; K-1407-J) and K-1203

\begin{tabular}{|c|c|c|c|c|}
\hline $\begin{array}{l}\text { K-25 Site } \\
\text { Outfall }\end{array}$ & Test Date & Species & $\begin{array}{l}\mathrm{NOEL}^{a} \\
(\%)\end{array}$ & $\begin{array}{r}\mathrm{LC}_{50}^{b} \\
(\%)\end{array}$ \\
\hline \multirow[t]{21}{*}{ CNF (Outfall 011) } & February 1990 & $\begin{array}{c}\text { Fathead minnows } \\
\text { Ceriodaphnia }\end{array}$ & $\begin{array}{c}100 \\
1\end{array}$ & $\begin{array}{r}>100 \\
17.3\end{array}$ \\
\hline & April 1990 & $\begin{array}{l}\text { Fathead minnows } \\
\text { Ceriodaphnia }\end{array}$ & $\begin{array}{c}50 \\
100\end{array}$ & $\begin{array}{l}>100 \\
>100\end{array}$ \\
\hline & June 1990 & $\begin{array}{l}\text { Fathead minnows } \\
\text { Ceriodpahnia }\end{array}$ & $\begin{array}{l}100 \\
100\end{array}$ & $\begin{array}{l}>100 \\
>100\end{array}$ \\
\hline & August 1990 & $\begin{array}{c}\text { Fathead minnows } \\
\text { Ceriodaphnia }\end{array}$ & $\begin{array}{l}100 \\
100\end{array}$ & $\begin{array}{l}>100 \\
>100\end{array}$ \\
\hline & October 1990 & $\begin{array}{l}\text { Fathead minnows } \\
\text { Ceriodaphnia }\end{array}$ & $\begin{array}{l}100 \\
100\end{array}$ & $\begin{array}{l}>100 \\
>100\end{array}$ \\
\hline & December 1990 & $\begin{array}{c}\text { Fathead minnows } \\
\text { Ceriodaphnia }\end{array}$ & $\begin{array}{l}100 \\
100\end{array}$ & $\begin{array}{l}>100 \\
>100\end{array}$ \\
\hline & February 1991 & $\begin{array}{c}\text { Fathead minnows } \\
\text { Ceriodaphnia }\end{array}$ & $\begin{array}{c}100 \\
50\end{array}$ & $\begin{array}{l}>100 \\
>100\end{array}$ \\
\hline & April 1991 & $\begin{array}{c}\text { Fathead minnows } \\
\text { Ceriodaphnia }\end{array}$ & $\begin{array}{l}100 \\
<1\end{array}$ & $\begin{array}{l}>100 \\
35.4\end{array}$ \\
\hline & May $1991^{c}$ & Ceriodaphnia & 50 & $>100$ \\
\hline & June 1991 & $\begin{array}{c}\text { Fathead minnows } \\
\text { Ceriodaphnia }\end{array}$ & $\begin{array}{c}100 \\
50\end{array}$ & $\begin{array}{l}>100 \\
>100\end{array}$ \\
\hline & August 1991 & $\begin{array}{l}\text { Fathead minnows } \\
\text { Ceriodaphnia }\end{array}$ & $\begin{array}{l}100 \\
100\end{array}$ & $\begin{array}{l}>100 \\
>100\end{array}$ \\
\hline & October 1991 & $\begin{array}{l}\text { Fathead minnows } \\
\text { Ceriodaphnia }\end{array}$ & $\begin{array}{c}100 \\
50\end{array}$ & $\begin{array}{l}>100 \\
>100\end{array}$ \\
\hline & December 1991 & $\begin{array}{c}\text { Fathead minnows } \\
\text { Ceriodaphnia }\end{array}$ & $\begin{array}{l}100 \\
100\end{array}$ & $\begin{array}{l}>100 \\
>100\end{array}$ \\
\hline & February 1992 & $\begin{array}{c}\text { Fathead minnows } \\
\text { Ceriodaphnia }\end{array}$ & $\begin{array}{c}100 \\
50\end{array}$ & $\begin{array}{l}>100 \\
>100\end{array}$ \\
\hline & April 1992 & $\begin{array}{c}\text { Fathead minnows } \\
\text { Ceriodaphnia }\end{array}$ & $\begin{array}{c}100 \\
25\end{array}$ & $\begin{array}{l}>100 \\
73.5\end{array}$ \\
\hline & June 1992 & $\begin{array}{c}\text { Fathead minnows } \\
\text { Ceriodaphnia }\end{array}$ & $\begin{array}{l}100 \\
100\end{array}$ & $\begin{array}{l}>100 \\
>100\end{array}$ \\
\hline & August 1992 & $\begin{array}{l}\text { Fathead minnows } \\
\text { Ceriodaphnia }\end{array}$ & $\begin{array}{l}100 \\
100\end{array}$ & $\begin{array}{l}>100 \\
>100\end{array}$ \\
\hline & November 1992 & $\begin{array}{c}\text { Fathead minnows } \\
\text { Ceriodaphnia }\end{array}$ & $\begin{array}{l}75 \\
75\end{array}$ & $\begin{array}{l}>75 \\
>75\end{array}$ \\
\hline & January 1993 & $\begin{array}{l}\text { Fathead minnows } \\
\text { Ceriodaphnia }\end{array}$ & $\begin{array}{l}75 \\
25\end{array}$ & $\begin{array}{l}>75 \\
>75\end{array}$ \\
\hline & March $1993^{d}$ & Fathead minnows & 25 & $>75$ \\
\hline & April 1993 & Ceriodaphnia & 75 & $>75$ \\
\hline
\end{tabular}


Table 3.1 (continued)

\begin{tabular}{|c|c|c|c|c|}
\hline $\begin{array}{l}\text { K-25 Site } \\
\text { Outfall }\end{array}$ & Test Date & Species & $\begin{array}{l}\text { NOEL }^{a} \\
(\%)\end{array}$ & $\begin{array}{l}\mathrm{LC}_{50}{ }^{b} \\
(\%)\end{array}$ \\
\hline & May 1993 & $\begin{array}{l}\text { Fathead minnows } \\
\text { Ceriodaphnia }\end{array}$ & $\begin{array}{l}75 \\
75\end{array}$ & $\begin{array}{l}>75 \\
>75\end{array}$ \\
\hline & July 1993 & $\begin{array}{l}\text { Fathead minnows } \\
\text { Ceriodaphnia }\end{array}$ & $\begin{array}{c}7.05 \\
25\end{array}$ & $\begin{array}{l}>7.05 \\
>25\end{array}$ \\
\hline & September 1993 & $\begin{array}{l}\text { Fathead minnows } \\
\text { Ceriodaphnia }\end{array}$ & $\begin{array}{l}75 \\
75\end{array}$ & $\begin{array}{l}>75 \\
>75\end{array}$ \\
\hline & November 1993 & $\begin{array}{l}\text { Fathead minnows } \\
\text { Ceriodaphnia }\end{array}$ & $\begin{array}{l}75 \\
25\end{array}$ & $\begin{array}{l}>75 \\
>75\end{array}$ \\
\hline \multirow[t]{14}{*}{ K-1203 (Outfall 005) } & June 1991 & $\begin{array}{l}\text { Fathead minnows } \\
\text { Ceriodaphnia }\end{array}$ & $\begin{array}{l}100 \\
100\end{array}$ & $\begin{array}{l}>100 \\
>100\end{array}$ \\
\hline & August 1991 & $\begin{array}{l}\text { Fathead minnows } \\
\text { Ceriodaphnia }\end{array}$ & $\begin{array}{l}100 \\
100\end{array}$ & $\begin{array}{l}>100 \\
>100\end{array}$ \\
\hline & November 1992 & $\begin{array}{l}\text { Fathead minnows } \\
\text { Ceriodaphnia }\end{array}$ & $\begin{array}{l}100 \\
100\end{array}$ & $\begin{array}{l}>100 \\
>100\end{array}$ \\
\hline & January 1993 & $\begin{array}{l}\text { Fathead minnows } \\
\text { Ceriodaphnia }\end{array}$ & $\begin{array}{l}100 \\
100\end{array}$ & $\begin{array}{l}>100 \\
>100\end{array}$ \\
\hline & March $1993^{d}$ & Fathead minnows & 100 & $>100$ \\
\hline & April 1993 & Ceriodaphnia & 100 & $>100$ \\
\hline & May 1993 & $\begin{array}{c}\text { Fathead minnows } \\
\text { Ceriodaphnia }\end{array}$ & $\begin{array}{l}100 \\
100\end{array}$ & $\begin{array}{l}>100 \\
>100\end{array}$ \\
\hline & July 1993 & $\begin{array}{l}\text { Fathead minnows } \\
\text { Ceriodaphnia }\end{array}$ & $\begin{array}{l}14.6 \\
<4.2\end{array}$ & $\begin{array}{l}>14.6 \\
>30\end{array}$ \\
\hline & August $1993^{d}$ & Ceriodaphnia & 30 & $>100$ \\
\hline & September 1993 & $\begin{array}{l}\text { Fathead minnows } \\
\text { Ceriodaphnia }\end{array}$ & $\begin{array}{l}100 \\
30\end{array}$ & $\begin{array}{l}>100 \\
>100\end{array}$ \\
\hline & November 1993 & $\begin{array}{l}\text { Fathead minnows } \\
\text { Ceriodaphnia }\end{array}$ & $\begin{array}{l}100 \\
14.6\end{array}$ & $\begin{array}{l}>100 \\
>100\end{array}$ \\
\hline & January 1994 & $\begin{array}{l}\text { Fathead minnows } \\
\text { Ceriodaphnia }\end{array}$ & $\begin{array}{l}100 \\
100\end{array}$ & $\begin{array}{l}>100 \\
>100\end{array}$ \\
\hline & March 1994 & $\begin{array}{l}\text { Fathead minnows } \\
\text { Ceriodaphnia }\end{array}$ & $\begin{array}{l}<4.2 \\
100\end{array}$ & $\begin{array}{l}>54.8 \\
>100\end{array}$ \\
\hline & March $1994^{\circ}$ & Fathead minnows & 30 & $>100$ \\
\hline
\end{tabular}

aNo-observed-effect level (the highest concentration of effluent tested that does not significantly reduce fathead minnow survival or growth or Ceriodaphnia survival or reproduction).

${ }^{b} 96-h$ lethal concentration for $50 \%$ of the test organisms.

${ }^{c}$ Confirmatory test.

${ }^{d}$ Invalid Ceriodaphnia test (unacceptable control survival); a retest was conducted in April 1993. 
A summary of water quality parameters for CNF is provided in Table 3.2. The chemical characteristics of the effluent have remained similar from 1990 to 1993 with the exception of one high mean conductivity value in April $1991(8663 \mu \mathrm{S} / \mathrm{cm})$ and lower mean alkalinity during 1993. Mean conductivity ranged from 800 to $8663 \mu \mathrm{S} / \mathrm{cm}$ with typical values around 1500 to $3000 \mu \mathrm{S} / \mathrm{cm}$. Mean alkalinity typically ranged from about 40 to $200 \mathrm{mg} / \mathrm{L}$ with one mean value equal to $462 \mathrm{mg} / \mathrm{L}$. Mean hardness ranged from 221 to $717 \mathrm{mg} / \mathrm{L}$.

\subsubsection{K-1203 Treatment Facility}

A summary of the NOELs for all toxicity tests conducted during January 1990 to March 1994 are provided in Table 3.1. In July 1993 and March 1994, effluent from K-1203 exceeded the NOEL limit in the renewed permit (4.2\%). Both of these exceedences were violations of the NPDES permit. Confirmatory tests were conducted within 2 weeks of the violation and no toxicity was observed (NOEL $=30 \%$ ).

A summary of water quality parameters for $\mathrm{K}-1203$ is provided in Table 3.2 . The chemical characteristics of the effluent have remained similar for 1991 to 1994 . Mean conductivity ranged from 326 to $435 \mu \mathrm{S} / \mathrm{cm}$, and mean alkalinity ranged from 81 to $109 \mathrm{mg} / \mathrm{L}$. Mean $\mathrm{pH}$ ranged from 7.61 to 8.09 .

\subsubsection{Storm drains 170,180 , and 190}

A summary of the NOELs and survival at 96 hours for toxicity tests conducted during January 1990 to April 1994, are provided in Table 3.3. Results of tests conducted during 1988-1989 are in Kszos (1994). During 1990-92, the NOEL for effluent from SDs 170, 180, and 190 was frequently, and for SD 170 and SD 190, Ceriodaphnia survival at $96 \mathrm{~h}$ was $0 \%$ for 3 to 5 tests. Because a complete dilution series was not used, the level of toxicity below full-strength could not be determined. Beginning in April 1993, test results were much more definitive. For SD 170, the NOEL for Ceriodaphnia was $\leq 50 \%$ in six of the seven tests conducted in 1993-94, and Ceriodaphnia survival at $96 \mathrm{~h}$ was $\geq 70 \%$. Full-strength effluent was non-toxic in only one test. After 1992, effluent from SD 180 was typically non-toxic to Ceriodaphnia: the NOEL was $100 \%$ in five of the seven tests conducted in 1993-94. Test results for SD 190 were similar to those for SD 170: full strength effluent was non-toxic in only one test in 1993-94. The NOEL was $\leq 50 \%$ effluent in six of the seven tests conducted 
Table 3.2. Average water quality parameters measured during toxicity tests of the Central Neutralization Facility

(CNF; K-1407-J) and K-1203

Values are averages of full-strength wastewater for each test $(n=7)$

\begin{tabular}{|c|c|c|c|c|c|}
\hline $\begin{array}{l}\text { Facility } \\
\text { (Outfall) }\end{array}$ & $\begin{array}{l}\text { Test } \\
\text { Date }\end{array}$ & $\begin{array}{c}\mathrm{pH} \\
\text { (standard units) }\end{array}$ & $\begin{array}{c}\text { Conductivity } \\
(\mu \mathrm{S} / \mathrm{cm})\end{array}$ & $\begin{array}{c}\text { Alkalinity } \\
\left(\mathrm{mg} / \mathrm{L} \mathrm{CaCO}_{3}\right)\end{array}$ & $\begin{array}{c}\text { Hardness } \\
\left(\mathrm{mg} / \mathrm{L} \mathrm{CaCO}_{3}\right)\end{array}$ \\
\hline \multirow[t]{26}{*}{ CNF (011) } & February 1990 & 7.82 & 1286 & 94 & 418 \\
\hline & April 1990 & 8.13 & 676 & 177 & 263 \\
\hline & June 1990 & 8.65 & 1927 & 462 & 197 \\
\hline & August 1990 & 8.54 & 952 & 151 & 244 \\
\hline & October 1990 & 8.31 & 1441 & 113 & 280 \\
\hline & December 1990 & 8.06 & 800 & 54 & 221 \\
\hline & February 1991 & 7.75 & 2979 & 61 & 596 \\
\hline & April 1991 & 7.84 & 8663 & 122 & 359 \\
\hline & May 1991 & 8.06 & 1886 & 120 & 431 \\
\hline & June 1991 & 7.87 & 1601 & 163 & 443 \\
\hline & August 1991 & 8.12 & 2187 & 224 & 456 \\
\hline & October 1991 & 7.90 & 3114 & 143 & 555 \\
\hline & December 1991 & 7.72 & 2249 & 126 & 611 \\
\hline & February 1992 & 8.10 & 2231 & 71 & 717 \\
\hline & April 1992 & 8.11 & 3206 & 113 & 677 \\
\hline & June 1992 & 7.97 & 1875 & 72 & 520 \\
\hline & August 1992 & 8.01 & 1454 & 85 & 424 \\
\hline & November 1992 & 7.81 & 1497 & 46 & 698 \\
\hline & January 1993 & 7.80 & 2831 & 52 & 594 \\
\hline & March 1993 & 7.69 & 1831 & 74 & 363 \\
\hline & April 1993 & 7.73 & 1484 & 41 & 568 \\
\hline & May 1993 & 7.76 & 1899 & 41 & 511 \\
\hline & July $1993^{a}$ & 7.92 & 3007 & 80 & 438 \\
\hline & July $1993^{b}$ & 7.57 & 4044 & 41 & 455 \\
\hline & September 1993 & 7.65 & 1808 & 54 & 639 \\
\hline & November 1993 & 7.63 & 1615 & 64 & 680 \\
\hline \multirow[t]{5}{*}{$\mathrm{K}-1203(005)$} & June 1991 & 7.64 & 326 & 87 & 131 \\
\hline & August 1991 & 7.61 & 350 & 85 & 142 \\
\hline & November 1992 & 8.03 & 384 & 107 & 161 \\
\hline & January 1993 & 7.97 & 390 & 101 & 149 \\
\hline & March 1993 & 8.09 & 380 & 101 & 172 \\
\hline
\end{tabular}


Table 3.2 (continued)

\begin{tabular}{|c|c|c|c|c|c|}
\hline $\begin{array}{l}\text { Facility } \\
\text { (Outfall) }\end{array}$ & $\begin{array}{l}\text { Test } \\
\text { Date }\end{array}$ & $\begin{array}{c}\text { pH } \\
\text { (standard units) }\end{array}$ & $\begin{array}{l}\text { Conductivity } \\
(\mu \mathrm{S} / \mathrm{cm})\end{array}$ & $\begin{array}{c}\text { Alkalinity } \\
\left.(\mathrm{mg} / \mathrm{L} \mathrm{CaCO})_{3}\right)\end{array}$ & $\begin{array}{c}\text { Hardness } \\
(\mathrm{mg} / \mathrm{L} \mathrm{CaCO})\end{array}$ \\
\hline \multirow{9}{*}{ - } & April 1993 & 8.02 & 390 & 96 & 158 \\
\hline & May 1993 & 7.93 & 402 & 85 & 147 \\
\hline & $\begin{array}{l}\text { July } 1993^{a} \\
\text { July } 1993^{b}\end{array}$ & $\begin{array}{l}7.71 \\
7.88\end{array}$ & $\begin{array}{l}400 \\
414\end{array}$ & $\begin{array}{l}86 \\
90\end{array}$ & $\begin{array}{l}155 \\
154\end{array}$ \\
\hline & August 1993 & 7.83 & 389 & 81 & 143 \\
\hline & September 1993 & 7.90 & 391 & 92 & 147 \\
\hline & November 1993 & 7.89 & 435 & 107 & 151 \\
\hline & January 1994 & 8.05 & 383 & 109 & 154 \\
\hline & March $1994^{c}$ & 8.01 & 373 & 108 & 151 \\
\hline & March $1994^{d}$ & 7.95 & 331 & 99 & 132 \\
\hline
\end{tabular}

${ }^{a}$ Data are for test conducted July 8-15, 1993.

${ }^{b}$ Data are for test conducted July 29-August 5, 1993.

'Data are for test conducted March 3-10, 1994.

${ }^{d}$ Data are for test conducted March 24-31, 1994. 
Table 3.3. Toxicity test results for storm drains 170, 180, and 190, 1990-1994

\begin{tabular}{|c|c|c|c|c|c|}
\hline \multirow[b]{2}{*}{$\begin{array}{l}\text { Storm } \\
\text { Drain }\end{array}$} & \multirow[b]{2}{*}{ Test Period } & \multicolumn{2}{|c|}{ Fathead Minnow } & \multicolumn{2}{|c|}{ Ceriodaphnia dubia } \\
\hline & & NOEL ${ }^{a}$ & Survival $^{b}$ at $96 \mathrm{~h}(\%)$ & NOEL ${ }^{a}$ & Survival $^{b}$ at $96 \mathrm{~h}(\%)$ \\
\hline \multirow[t]{21}{*}{170} & Jan. 1990 & $<100$ & 0 & $<100$ & 0 \\
\hline & dechlor. & 100 & 100 & $<100$ & 100 \\
\hline & May 1990 & $<100$ & 100 & 100 & 100 \\
\hline & dechlor. & 100 & 97.5 & 100 & 100 \\
\hline & Nov. 1990 & $<100$ & 0 & $<100$ & 0 \\
\hline & dechlor. & 100 & 95 & $<50$ & 0 \\
\hline & May 1991 & 100 & 85 & $<100$ & 0 \\
\hline & dechlor. & 100 & 90 & $<100$ & 0 \\
\hline & Nov. 1991 & NT & NT & $<75$ & $100(0)^{c}$ \\
\hline & Mar. 1992 & I & 1 & 75 & 100 \\
\hline & May 1992 & 100 & 97.5 & $<75$ & $80(40)^{d}$ \\
\hline & July 1992 & 100 & 95 & 50 & 90 \\
\hline & Sept. 1992 & 100 & $\mathrm{NT}$ & $<50$ & 20 \\
\hline & Nov. 1992 & NT & NT & $<50$ & 90 \\
\hline & Apr. 1993 & NT & NT & $<12$ & 100 \\
\hline & June 1993 & NT & NT & .100 & 100 \\
\hline & Aug. 1993 & NT & NT & 25 & 100 \\
\hline & Oct. 1993 & NT & NT & 25 & 100 \\
\hline & Dec. 1993 & NT & NT & 25 & 70 \\
\hline & Feb. 1994 & NT & NT & $<50$ & 100 \\
\hline & Apr. 1994 & NT & NT & 50 & 100 \\
\hline \multirow[t]{11}{*}{180} & Jan. 1990 & 100 & 95 & $<100$ & $80(30)^{e}$ \\
\hline & May 1990 & 100 & 100 & 100 & 100 \\
\hline & Nov. 1990 & $<100$ & 0 & $<100$ & 100 \\
\hline & May 1991 & $<100$ & 62.5 & 100 & 100 \\
\hline & dechlor. & $<100$ & 57.5 & 100 & 100 \\
\hline & Nov. 1991 & NT & NT & 100 & 100 \\
\hline & Mar. 1992 & I & I & 100 & 100 \\
\hline & May 1992 & $<100$ & 72.5 & $<75$ & 100 \\
\hline & July 1992 & 100 & 97.5 & 50 & 80 \\
\hline & Apr. 1993 & NT & NT & 50 & 60 \\
\hline & June 1993 & NT & NT & 100 & 100 \\
\hline
\end{tabular}


Table 3.3 (continued)

\begin{tabular}{|c|c|c|c|c|c|}
\hline \multirow{3}{*}{$\begin{array}{l}\text { Storm } \\
\text { Drain }\end{array}$} & \multirow[b]{3}{*}{ Test Period } & \multicolumn{2}{|c|}{ Fathead Minnow } & \multicolumn{2}{|c|}{ Ceriodaphnia dubia } \\
\hline & & & Survival $^{b}$ at $96 \mathrm{~h}(\%)$ & & Survival $^{b}$ at $96 \mathrm{~h}(\%)$ \\
\hline & & NOEL $L^{a}$ & & $\mathrm{NOEL}^{a}$ & \\
\hline \multirow{5}{*}{-} & Aug. 1993 & NT & NT & 100 & 100 \\
\hline & Oct. 1993 & NT & NT & 100 & 100 \\
\hline & Dec. 1993 & NT & NT & 50 & 100 \\
\hline & Feb. 1994 & NT & NT & 100 & 100 \\
\hline & Apr. 1994 & NT & NT & 100 & 100 \\
\hline \multirow[t]{19}{*}{ SD190 } & Jan. 1990 & 100 & 95 & $<100$ & 0 \\
\hline & dechlor. & 100 & 90 & 100 & 90 \\
\hline & May 1990 & 100 & 95 & 75 & 0 \\
\hline & Nov. 1990 & $<100$ & 0 & $<100$ & 0 \\
\hline & dechlor. & 100 & 100 & 100 & 100 \\
\hline & May 1991 & 100 & 92.5 & $<100$ & 0 \\
\hline & dechlor. & 100 & 92.5 & 100 & 100 \\
\hline & Nov. 1991 & NT & NT & $<100^{r}$ & $0^{f}$ \\
\hline & dechlor. & NT & NT & $<75$ & 90 \\
\hline & Mar. 1992 & 1 & I & 100 & 100 \\
\hline & May 1992 & 100 & 92.5 & $<75$ & 100 \\
\hline & July 1992 & 100 & 97.5 & 50 & 90 \\
\hline & Apr. 1993 & NT & NT & $<12$ & 0 \\
\hline & June 1993 & NT & NT & $<12$ & 0 \\
\hline & Aug. 1993 & $\mathrm{NT}$ & NT & 100 & 100 \\
\hline & Oct. 1993 & NT & NT & 50 & 90 \\
\hline & Dec. 1993 & NT & NT & 12 & 80 \\
\hline & Feb. 1994 & NT & NT & $<50$ & 0 \\
\hline & Apr. 1994 & NT & NT & $<50$ & 0 \\
\hline
\end{tabular}

Note: $\mathrm{I}=$ invalid test (unacceptable control survival); $\mathrm{NT}=$ not tested; dechlor. $=$ dechlorinated with sodium thiosulfate.

No-observed-effect level (the highest concentration of effluent tested that does not significantly reduce fathead minnow survival or growth or Ceriodaphnia survival or reproduction).

${ }^{b}$ Survival in full-strength effluent.

'Survival was $0 \%$ in $5 \mathrm{~d}$.

Survival was $40 \%$ in $7 \mathrm{~d}$.

'Survival was $30 \%$ in $7 \mathrm{~d}$.

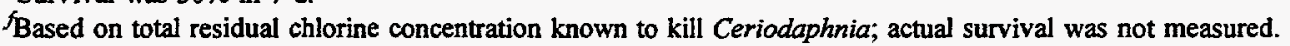


in 1993-94. Survival of Ceriodaphnia at $96 \mathrm{~h}$ remained low in 1993-94: survival was 0\% in 4 of the 7 tests.

A summary of water quality parameters for the storm drains is provided in Table 3.4, and mean and maximum concentrations of total residual chlorine (TRC) are given in Table 3.5. The chemical characteristics of each effluent have remained similar from 1991 to 1994 and are similar to each other. Mean conductivity at SDs 170,180 , and 190 ranged from $301-501 \mu \mathrm{S} / \mathrm{cm}, 358-572 \mu \mathrm{S} / \mathrm{cm}$, and 261-560 $\mu \mathrm{S} / \mathrm{cm}$ respectively. Mean hardness at SDs 170,180 , and 190 ranged from $135-286 \mathrm{mg} / \mathrm{L}, 175-207 \mathrm{mg} / \mathrm{L}$, and $135-250 \mathrm{mg} / \mathrm{L}$ respectively. Mean alkalinity at SDs 170,180 , and 190 ranged from $94-140 \mathrm{mg} / \mathrm{L}$, 129-162 mg/L, and 101-195 mg/L respectively. During 1990, TRC was always present in effluent from SDs 170 and 190; the maximum concentration measured in SDs 170 and 190 was $0.91 \mathrm{mg} / \mathrm{L}$ and $1.03 \mathrm{mg} / \mathrm{L}$ respectively. In 1991, the maximum TRC concentrations measured in SDs 170 and 190 were 0.02 and $0.21 \mathrm{mg} / \mathrm{L}$ respectively. Measurements taken after November 1991 are not shown because TRC was never greater than $0.03 \mathrm{mg} / \mathrm{L}$.

\subsubsection{Discussion}

Effluent from CNF has not exceeded the permit limits since the effective date of the renewed permit (October 1992). In February 1990 and April 1991, the effluent was highly toxic to Ceriodaphnia (NOEL $\leq 1$ ). Thus, effluent from CNF was toxic (as defined by the permit) in 2 of the past 47 tests. In terms of toxicity, it is very unlikely that there is any continuous impact on the aquatic biota of Poplar Creek. However, the two cases of toxicity at low concentrations of effluent indicate that an episodic event could have impacted the biota of Poplar Creek. The toxicity observed in April 1991 coincided with the highest mean conductivity ( $8663 \mu \mathrm{S} / \mathrm{cm}$ ) measured during 1990-93. Conductivity (from the presence of dissolved solids) does not really measure the toxicant, rather it is an indicator of the presence of a toxicant; a $1 \%$ concentration of effluent would contain very low dissolved solids, yet a $1 \%$ concentration of effluent was toxic to Ceriodaphnia. Water quality data collected in February 1990 did not provide any information concerning the source of the toxicant. The cause or the source of toxicity in the CNF effluent was not identified. Because there was no biotic sampling ongoing during either of the toxicity tests, the level of impact is unknown; however, no fish kills in Poplar Creek were reported to ESD during either toxicity test. 
Table 3.4. Average water quality parameters measured during toxicity tests of storm drains 170,180 and 190

Values are averages of full-strength wastewater for each test $(n=7)$

\begin{tabular}{|c|c|c|c|c|c|}
\hline $\begin{array}{l}\text { Storm } \\
\text { Drain }\end{array}$ & $\begin{array}{l}\text { Test } \\
\text { Date }\end{array}$ & $\begin{array}{c}\mathrm{pH} \\
\text { (standard units) }\end{array}$ & $\begin{array}{c}\text { Conductivity } \\
(\mu \mathrm{S} / \mathrm{cm})\end{array}$ & $\begin{array}{c}\text { Alkalinity } \\
(\mathrm{mg} / \mathrm{L} \mathrm{CaCO})_{3}\end{array}$ & $\begin{array}{c}\text { Hardness } \\
\left(\mathrm{mg} / \mathrm{L} \mathrm{CaCO}_{3}\right)\end{array}$ \\
\hline \multirow[t]{17}{*}{170} & January 1990 & 7.98 & 501 & 94 & 135 \\
\hline & May 1990 & 8.08 & 490 & 108 & 286 \\
\hline & November 1990 & 8.12 & 403 & 122 & 175 \\
\hline & May 1991 & 8.02 & 405 & 140 & 184 \\
\hline & November 1991 & 7.90 & 339 & 126 & 175 \\
\hline & March 1992 & 8.17 & 321 & 111 & 160 \\
\hline & May 1992 & 8.20 & 329 & 118 & 166 \\
\hline & July 1992 & 8.24 & 339 & 115 & 162 \\
\hline & September 1992 & 8.21 & 346 & 120 & 164 \\
\hline & November 1992 & 8.26 & 333 & 119 & 162 \\
\hline & April 1993 & 8.20 & 324 & 99 & 190 \\
\hline & June 1993 & 8.10 & 352 & 123 & 179 \\
\hline & August 1993 & 8.20 & 358 & 119 & 189 \\
\hline & October 1993 & 8.10 & 346 & 115 & 167 \\
\hline & December 1993 & 8.10 & 358 & 106 & 153 \\
\hline & February 1994 & 8.10 & 346 & $105^{\circ}$ & 169 \\
\hline & April 1994 & 8.20 & 301 & 99 & 151 \\
\hline \multirow[t]{12}{*}{180} & January 1990 & 8.05 & 572 & 109 & 203 \\
\hline & May 1990 & 8.19 & 358 & 131 & 175 \\
\hline & November 1990 & 8.15 & 407 & 153 & 195 \\
\hline & May 1991 & 8.05 & 456 & 162 & 207 \\
\hline & November 1991 & 7.96 & 367 & 137 & 192 \\
\hline & March 1992 & 8.12 & 415 & 153 & 203 \\
\hline & May 1992 & 8.20 & 364 & 142 & 189 \\
\hline & July 1992 & 8.31 & 365 & 141 & 180 \\
\hline & April 1993 & 8.30 & 377 & 146 & 207 \\
\hline & June 1993 & 8.10 & 380 & 141 & 204 \\
\hline & August 1993 & 8.20 & 379 & 139 & 199 \\
\hline & October 1993 & 8.10 & 389 & 137 & 186 \\
\hline
\end{tabular}


Table 3.4 (continued)

\begin{tabular}{|c|c|c|c|c|c|}
\hline $\begin{array}{l}\text { Storm } \\
\text { Drain }\end{array}$ & $\begin{array}{l}\text { Test } \\
\text { Date }\end{array}$ & $\begin{array}{c}\mathrm{pH} \\
\text { (standard units) }\end{array}$ & $\begin{array}{l}\text { Conductivity } \\
(\mu \mathrm{S} / \mathrm{cm})\end{array}$ & $\begin{array}{c}\text { Alkalinity } \\
\left.(\mathrm{mg} / \mathrm{L} \mathrm{CaCO})_{3}\right)\end{array}$ & $\begin{array}{c}\text { Hardness } \\
(\mathrm{mg} / \mathrm{L} \mathrm{CaCO} \text { ) }\end{array}$ \\
\hline \multirow{18}{*}{190} & December 1993 & 8.20 & 410 & 129 & 183 \\
\hline & February 1994 & 8.20 & 409 & 144 & 187 \\
\hline & April 1994 & 8.20 & 388 & 145 & 201 \\
\hline & January 1990 & 8.02 & 315 & 110 & 157 \\
\hline & May 1990 & 8.04 & 318 & 118 & 159 \\
\hline & November 1990 & 8.12 & 295 & 115 & 145 \\
\hline & May 1991 & 7.96 & 308 & 113 & 148 \\
\hline & November 1991 & 7.90 & 261 & 111 & 148 \\
\hline & March 1992 & 8.07 & 311 & 117 & 153 \\
\hline & May 1992 & 8.12 & 284 & 101 & 149 \\
\hline & July 1992 & 8.18 & 308 & 107 & 135 \\
\hline & April 1993 & 8.30 & 560 & 195 & 266 \\
\hline & June 1993 & 8.10 & 434 & 146 & 205 \\
\hline & August 1993 & 8.00 & 442 & 143 & 206 \\
\hline & October 1993 & 7.90 & 432 & 153 & 209 \\
\hline & December 1993 & 7.80 & 482 & 159 & 209 \\
\hline & February 1994 & 7.90 & 462 & 160 & 239 \\
\hline & April 1994 & 8.00 & 482 & 173 & 250 \\
\hline
\end{tabular}


Table 3.5. Summary (mean and range) of total residual chlorine measured during toxicity tests of storm drains and ambient waters from Mitchell Branch

\begin{tabular}{|c|c|c|c|}
\hline Sample & Date & $\begin{array}{c}\text { Total } \\
\text { Residual } \\
\text { Chlorine } \\
(\mathrm{mg} / \mathrm{L})\end{array}$ & Range \\
\hline MIK 0.71 & Jan. 1990 & 0.03 & $0.00-0.06$ \\
\hline MIK 0.54 & & 0.03 & $0.00-0.04$ \\
\hline MIK 0.45 & & 0.03 & $0.00-0.05$ \\
\hline MIK 0.12 & & 0.01 & $0.00-0.03$ \\
\hline SD 170 & & 0.37 & $0.00-0.64$ \\
\hline SD 180 & & 0.00 & $0.00-0.00$ \\
\hline SD 190 & & 0.17 & $0.00-0.26$ \\
\hline MIK 0.71 & March 1990 & 0.07 & $0.01-0.17$ \\
\hline MIK 0.54 & & 0.04 & $0.01-0.11$ \\
\hline MIK 0.45 & · & 0.04 & $0.02-0.08$ \\
\hline MIK 0.12 & & 0.02 & $0.00-0.06$ \\
\hline MIK 0.71 & May 1990 & 0.00 & $0.00-0.00$ \\
\hline MIK 0.54 & & 0.00 & $0.00-0.00$ \\
\hline MIK 0.45 & & 0.01 & $0.00-0.08$ \\
\hline MIK 0.12 & & 0.00 & $0.00-0.00$ \\
\hline SD 170 & & 0.11 & $0.00-0.69$ \\
\hline SD 180 & & 0.02 & $0.00-0.05$ \\
\hline SD 190 & & 0.03 & $0.00-0.06$ \\
\hline MIK 0.71 & July 1990 & 0.31 & $0.14-0.48$ \\
\hline MIK 0.54 & & 0.12 & $0.06-0.16$ \\
\hline MIK 0.45 & & 0.16 & $0.09-0.22$ \\
\hline MIK 0.12 & & 0.04 & $0.02-0.05$ \\
\hline MIK 1.00 & Sep. 1990 & 0.01 & $0.00-0.04$ \\
\hline MIK 0.71 & & 0.60 & $0.13-0.84$ \\
\hline MIK 0.54 & & 0.27 & $0.12-0.40$ \\
\hline MIK 0.45 & Sep. 1990 & 0.33 & $0.25-0.42$ \\
\hline MIK 0.12 & & 0.08 & $0.04-0.13$ \\
\hline MIK 0.71 & Nov. 1990 & 0.44 & $0.01-0.78$ \\
\hline MIK 0.54 & & 0.25 & $0.00-0.44$ \\
\hline MIK 0.45 & & 0.28 & $0.01-0.47$ \\
\hline MIK 0.12 & & 0.09 & $0.00-0.12$ \\
\hline
\end{tabular}


Table 3.5 (continued)

\begin{tabular}{|c|c|c|c|}
\hline Sample & Date & $\begin{array}{l}\text { Total } \\
\text { Residual } \\
\text { Chlorine } \\
\text { (mg/L) }\end{array}$ & Range \\
\hline SD 170 & & 0.56 & $0.05-0.91$ \\
\hline SD 180 & & 0.01 & $0.00-0.01$ \\
\hline SD 190 & & 0.75 & $0.17-1.03$ \\
\hline MIK 0.71 & Jan. 1991 & 0.04 & $0.02-0.05$ \\
\hline MIK 0.54 & & 0.03 & $0.02-0.04$ \\
\hline MIK 0.45 & & 0.03 & $0.02-0.06$ \\
\hline MIK 0.12 & & 0.01 & $0.00-0.01$ \\
\hline MIK 0.71 & March 1991 & 0.00 & $0.00-0.00$ \\
\hline MIK 0.54 & & 0.00 & $0.00-0.00$ \\
\hline MIK 0.45 & & 0.01 & $0.00-0.04$ \\
\hline MK 0.12 & & 0.00 & $0.00-0.00$ \\
\hline MIK 0.71 & May 1991 & 0.00 & $0.00-0.00$ \\
\hline MIK 0.54 & & 0.00 & $0.00-0.00$ \\
\hline MIK 0.45 & & 0.02 & $0.00-0.05$ \\
\hline MIK 0.12 & & 0.00 & $0.00-0.00$ \\
\hline SD 170 & & 0.00 & $0.00-0.02$ \\
\hline SD 180 & & 0.00 & $0.00-0.00$ \\
\hline SD 190 & & 0.13 & $0.11-0.21$ \\
\hline MIK 0.71 & July 1991 & 0.00 & $0.00-0.00$ \\
\hline MIK 0.54 & & 0.00 & $0.00-0.01$ \\
\hline MIK 0.45 & & 0.00 & $0.00-0.01$ \\
\hline MIK 0.12 & & 0.00 & $0.00-0.00$ \\
\hline MIK 0.71 & Sep. 1991 & 0.01 & $0.00-0.02$ \\
\hline MIK 0.54 & & 0.02 & $0.01-0.03$ \\
\hline MIK 0.45 & & 0.07 & $0.00-0.11$ \\
\hline MIK 0.12 & & 0.01 & $0.00-0.01$ \\
\hline MIK 0.71 & Nov. 1991 & 0.00 & $0.00-0.00$ \\
\hline MIK 0.54 & & 0.00 & $0.00-0.00$ \\
\hline MIK 0.45 & & 0.00 & $0.00-0.00$ \\
\hline MIK 0.12 & & 0.00 & $0.00-0.00$ \\
\hline SD 170 & & 0.00 & $0.00-0.00$ \\
\hline SD 180 & & 0.00 & $0.00-0.00$ \\
\hline
\end{tabular}


Table 3.5 (continued)

\begin{tabular}{|c|c|c|c|}
\hline Sample & Date & $\begin{array}{c}\text { Total } \\
\text { Residual } \\
\text { Chlorine } \\
\text { (mg/L) }\end{array}$ & Range \\
\hline SD 190 & & 0.66 & $0.18-0.98$ \\
\hline MIK 0.71 & Jan. 1992 & 0.00 & $0.00-0.00$ \\
\hline MIK 0.54 & & 0.00 & $0.00-0.00$ \\
\hline MIK 0.45 & & 0.00 & $0.00-0.00$ \\
\hline MIK 0.12 & & 0.00 & $0.00-0.00$ \\
\hline MIK 0.71 & March 1992 & 0.00 & $0.00-0.00$ \\
\hline MIK 0.54 & & 0.00 & $0.00-0.00$ \\
\hline MIK 0.45 & & 0.00 & $0.00-0.00$ \\
\hline MIK 0.12 & & 0.00 & $0.00-0.00$ \\
\hline SD 170 & & 0.00 & $0.00-0.01$ \\
\hline SD 180 & & 0.00 & $0.00-0.00$ \\
\hline SD 190 & & 0.00 & $0.00-0.00$ \\
\hline MIK 0.71 & May 1992 & 0.00 & $0.00-0.00$ \\
\hline MIK 0.54 & & 0.00 & $0.00-0.00$ \\
\hline MIK 0.45 & & 0.00 & $0.00-0.00$ \\
\hline MIK 0.12 & & 0.00 & $0.00-0.00$ \\
\hline SD 170 & May 1992 & 0.00 & $0.00-0.00$ \\
\hline SD 180 & & 0.00 & $0.00-0.01$ \\
\hline SD 190 & & 0.00 & $0.00-0.00$ \\
\hline MIK 0.71 & July 1992 & 0.00 & $0.00-0.01$ \\
\hline MK 0.54 & & 0.00 & $0.00-0.00$ \\
\hline MK 0.45 & & 0.00 & $0.00-0.00$ \\
\hline MIK 0.12 & & 0.00 & $0.00-0.00$ \\
\hline SD 170 & & 0.00 & $0.00-0.00$ \\
\hline SD 180 & & 0.00 & $0.00-0.00$ \\
\hline SD 190 & & 0.00 & $0.00-0.00$ \\
\hline MIK 0.71 & Sep. 1992 & 0.00 & $0.00-0.02$ \\
\hline MIK 0.54 & & 0.00 & $0.00-0.00$ \\
\hline MIK 0.45 & & 0.00 & $0.00-0.00$ \\
\hline MIK 0.12 & & 0.00 & $0.00-0.01$ \\
\hline SD 170 & & 0.01 & $0.01-0.02$ \\
\hline MIK 0.71 & Nov 1992 & 0.00 & $0.00-0.03$ \\
\hline
\end{tabular}


Table 3.5 (continued)

\begin{tabular}{|c|c|c|c|}
\hline Sample & Date & $\begin{array}{c}\text { Total } \\
\text { Residual } \\
\text { Chlorine } \\
(\mathrm{mg} / \mathrm{L})\end{array}$ & Range \\
\hline MIK 0.54 & & 0.00 & $0.00-0.00$ \\
\hline MIK 0.45 & & 0.00 & $0.00-0.00$ \\
\hline SD 170 & & 0.02 & $0.01-0.04$ \\
\hline MIK 0.71 & Feb. 1993 & 0.00 & $0.00-0.01$ \\
\hline MIK 0.54 & & 0.00 & $0.00-0.02$ \\
\hline MIK 0.45 & & 0.00 & $0.00-0.01$ \\
\hline MIK 0.12 & & 0.00 & $0.00-0.02$ \\
\hline MIK 0.71 & Apr. 1993 & 0.00 & $0.00-0.01$ \\
\hline MIK 0.54 & & 0.00 & $0.00-0.01$ \\
\hline MIK 0.45 & & 0.00 & $0.00-0.02$ \\
\hline MIK 0.12 & & 0.00 & $0.00-0.01$ \\
\hline SD 170 & Apr. 1993 & 0.01 & $0.00-0.03$ \\
\hline SD 180 & & 0.02 & $0.01-0.03$ \\
\hline SD 190 & & 0.00 & $0.00-0.01$ \\
\hline SD 170 & June 1993 & 0.00 & $0.00-0.00$ \\
\hline SD 180 & & 0.00 & $0.00-0.01$ \\
\hline SD 190 & & 0.00 & $0.00-0.00$ \\
\hline MK 0.71 & July 1993 & 0.00 & $0.00-0.00$ \\
\hline MIK 0.54 & & 0.00 & $0.00-0.00$ \\
\hline MIK 0.45 & & 0.00 & $0.00-0.00$ \\
\hline MIK 0.12 & & 0.00 & $0.00-0.00$ \\
\hline SD 170 & Aug. 1993 & 0.00 & $0.00-0.00$ \\
\hline SD 180 & & 0.00 & $0.00-0.00$ \\
\hline SD 190 & & 0.00 & $0.00-0.00$ \\
\hline MIK 0.71 & Oct. 1993 & 0.00 & $0.00-0.00$ \\
\hline MIK 0.54 & & 0.00 & $0.00-0.00$ \\
\hline MIK 0.45 & & 0.00 & $0.00-0.00$ \\
\hline MIK 0.12 & & 0.00 & $0.00-0.00$ \\
\hline SD 170 & & 0.00 & $0.00-0.00$ \\
\hline SD 180 & & 0.00 & $0.00-0.00$ \\
\hline SD 190 & & 0.00 & $0.00-0.00$ \\
\hline SD 170 & Dec. 1993 & 0.00 & $0.00-0.00$ \\
\hline
\end{tabular}


Table 3.5 (continued)

\begin{tabular}{lccc}
\hline Sample & Date & $\begin{array}{c}\text { Total } \\
\text { Residual } \\
\text { Chlorine } \\
(\mathrm{mg} / \mathrm{L})\end{array}$ & Range \\
\hline SD 180 & 0.00 & $0.00-0.00$ \\
SD 190 & 0.00 & $0.00-0.00$ \\
MIK 0.71 & Jan. 1994 & 0.00 & $0.00-0.00$ \\
MIK 0.54 & 0.00 & $0.00-0.00$ \\
MIK 0.45 & 0.00 & $0.00-0.00$ \\
MIK 0.12 & 0.00 & $0.00-0.00$ \\
\hline
\end{tabular}

Note: SD $=$ storm drain. MIK $=$ Mitchell Branch kilometer. 
Effluent from K-1203 has exceeded the permit limits twice since testing began. In July 1993, Ceriodaphnia reproduction was significantly reduced at $4.2 \%$, and in March 1994 , fathead minnow survival was significantly reduced at $4.2 \%$. In both cases, a test was conducted within 2 weeks and no effect on reproduction or survival was observed at $30 \%$ (the highest concentration tested). This lack of toxicity indicates that the toxicity observed in July 1993 and March 1994 was transient. At this time, the cause or source of the toxicity has not been identified. Although the effluent exceeded the permit limits twice, there have been 22 tests in which no toxicity (as defined by the permit) has been observed; thus, it is unlikely that there is any continuous impact on the biota. However, as was the case for CNF, the two cases of toxicity at low concentrations of effluent indicate that an episodic event could have impacted the biota of Poplar Creek. At this time, the cause or source of the toxicity has not been identified. No fish kills in Poplar Creek were reported to ESD during either toxicity test.

Effluent from SD 180 is typically non-toxic to Ceriodaphnia. Effluent from SDs 170 and 190 has consistently produced NOELs of $\leq 50 \%$. Previous to 1991 , much of the toxicity (but not all) was attributed to TRC (Kszos 1994). Dechlorination of the storm drains at the discharge point began in 1991 and removed some of the acute toxicity, as evidenced by the increase in survival at $96 \mathrm{~h}$ (Table 3.3). Dechlorination did not remove all the chronic or acute toxicity to Ceriodaphnia. In particular, effluent from SD 190 decreased Ceriodaphnia 96-h survival to $0 \%$ in 4 of the 7 tests conducted in 1993-94. The low survival is not due to total residual chlorine because concentrations have not been measured above $0.03 \mathrm{mg} / \mathrm{L}$ since 1991. During 1990-91, concentrations of TRC in effluent from SDs 170 and 190 frequently exceeded the EPA water quality criteria for chronic exposure (0.011 mg/L) (EPA 1986b). Since November 1991, TRC concentrations have typically been $0.0 \mathrm{mg} / \mathrm{L}$. See section 3.2 .4 for further discussion of the impact of storm drain effluents on Mitchell Branch.

\subsection{AMBIENT TOXICITY}

\subsubsection{Introduction}

Ambient toxicity monitoring at the K-25 Site employed the Ceriodaphnia and fathead minnow tests described in Sect. 3.1. Toxicity monitoring was incorporated into BMAP in order to (1) evaluate area source contributions to stream toxicity, (2) characterize patterns of toxicity in Mitchell Branch and Poplar Creek, (3) document changes in water quality attributable to changes in operations at the K-25 Site and (4) provide data demonstrating that the effluent 
limitations established for the K-25 Site protect and maintain the use of Mitchell Branch, Poplar Creek, and Clinch River for growth and propagation of fish and aquatic life. Sites in Poplar Creek and Clinch River were added in April 1993 when the revised BMAP (Kszos et al. 1993) was published. The sites chosen for testing on Mitchell Branch, Poplar Creek, and the Clinch River were selected to bracket area and point source discharges into the stream and to correspond closely to those selected as instream monitoring study sites. The Poplar Creek and Clinch River sites are shared with the CRRI (R. B. Cook et al., 1993).

\subsubsection{Materials and Methods}

Ambient toxicity was evaluated using the fathead minnow and Ceriodaphnia tests as described in Sect. 3.1 for effluents with the following exceptions: (1) no dilutions were tested, (2) each test of Mitchell Branch used seven consecutive, daily grab samples of stream water, and (3) each test of Poplar Creek and Clinch River used three grab samples collected over 6 days. Six ambient sites on Mitchell Branch (MIK 1.43, MIK 1.0 or MIK 0.78, MIK 0.71, MIK 0.54, MIK 0.45, and MIK 0.12; Fig. 2.2), five sites on Poplar Creek (PCK 18.2, PCK 8.2, PCK 6.9, PCK 4.7, and PCK 1.6, Fig. 2.1), and one site on the Clinch River (CRK 15.0; Fig. 2.1) were evaluated for toxicity. These Mitchell Branch sites are similar to those selected for the ecological monitoring component of BMAP (Sect. 5). The site at MIK 1.0 was moved to MIK 0.78 in April 1993 to coincide with the benthic macroinvertebrate sampling site. Testing of the Poplar Creek and Clinch River sites began in April 1993. Toxicity tests with Ceriodaphnia and fathead minnows were conducted approximately every other month from January 1990 to February 1993. Quarterly testing began with implementation of the new BMAP plan (Kszos et al. 1993) in April 1993. Water sampling and water chemistry analyses were conducted as described for the effluents in Sect. 3.1.2. Results of toxicity tests conducted in 1987-89 are presented in Kszos (1993 and 1994).

SAS statistical software (Statistical Analysis System for personal computers, release 6.03) was used to analyze all data. Survival percentages for fathead minnow larvae and for Ceriodaphnia were transformed (arcsine square root; Steel and Torrie 1960) before being analyzed. All fecundity values are for females that survived all 6 or $7 \mathrm{~d}$ of the test.

Differences in hardness, alkalinity, conductivity, fathead minnow survival and growth, and Ceriodaphnia reproduction between sites were evaluated with an analysis of variance (ANOVA) by using the SAS general linear models (GLM) procedure (SAS 1985a, 1985b); 
significant differences were then separated with Tukey's studentized range test. The Tukey test was selected because it accommodates unequal sample sizes. Because significant differences existed from test to test in Ceriodaphnia reproduction and fathead minnow survival and growth, the GLM procedure was inappropriate for separating differences among all sites and tests. Thus, separate GLM analyses were conducted for each test period. For each test period, significant reductions in Ceriodaphnia survival were determined by using Fisher's Exact Test (Weber et al. 1989). Significant reductions in Ceriodaphnia survival and reproduction in Mitchell Branch, Poplar Creek, and Clinch River sites are based on comparisons with the reference sites (MIK 1.43 for Mitchell Branch and PCK 18.2 for Poplar Creek and Clinch River). Fathead minnow survival at the reference site MIK 1.43 is typically low and is hypothesized to be due to a natural pathogen (Kszos 1993, 1994). Thus, significant reductions in minnow survival or growth at the sites were based on a comparison with survival and growth in a laboratory control water. Unless otherwise noted, statements of significance (probability) are based on $p=0.05$.

\subsubsection{Results}

\subsubsection{Water chemistry}

\section{Mitchell Branch}

Mean $\mathrm{pH}$, alkalinity, hardness, and conductivity for each site and test from 1990 through 94 are provided in Appendix B (Table B.1). Annual mean conductivity, alkalinity, and hardness are presented in Fig. 3.1. Chemistry measurements for 1990-94 are presented in Fig. 3.2.

Each year (Fig. 3.1), conductivity, alkalinity, and hardness were significantly lower at MIK 1.43 than at sites further downstream. Conductivity increased with distance downstream from approximately $180 \mu \mathrm{S} / \mathrm{cm}$ at MIK 1.43 to $350 \mu \mathrm{S} / \mathrm{cm}$ at MIK 0.12 (Figs. 3.1 and 3.2). In 1990,1991 , and 1992, conductivity at MIK 1.0 was significantly higher than at MIK 1.43 and significantly lower than at sites further downstream. In 1993, conductivity was not different from MIK 0.78 (which replaced MIK 1.0) downstream to MIK 0.12. Each year, conductivity at MIK 0.71 was significantly lower than at MIK 0.12 but not from MIK 0.71 downstream to MIK 0.45. The comparison of conductivity for all test dates (Table 3.6) showed that MIK 0.45 could be distinguished from MIK 0.71 and that adjacent sites were not different from each other. 

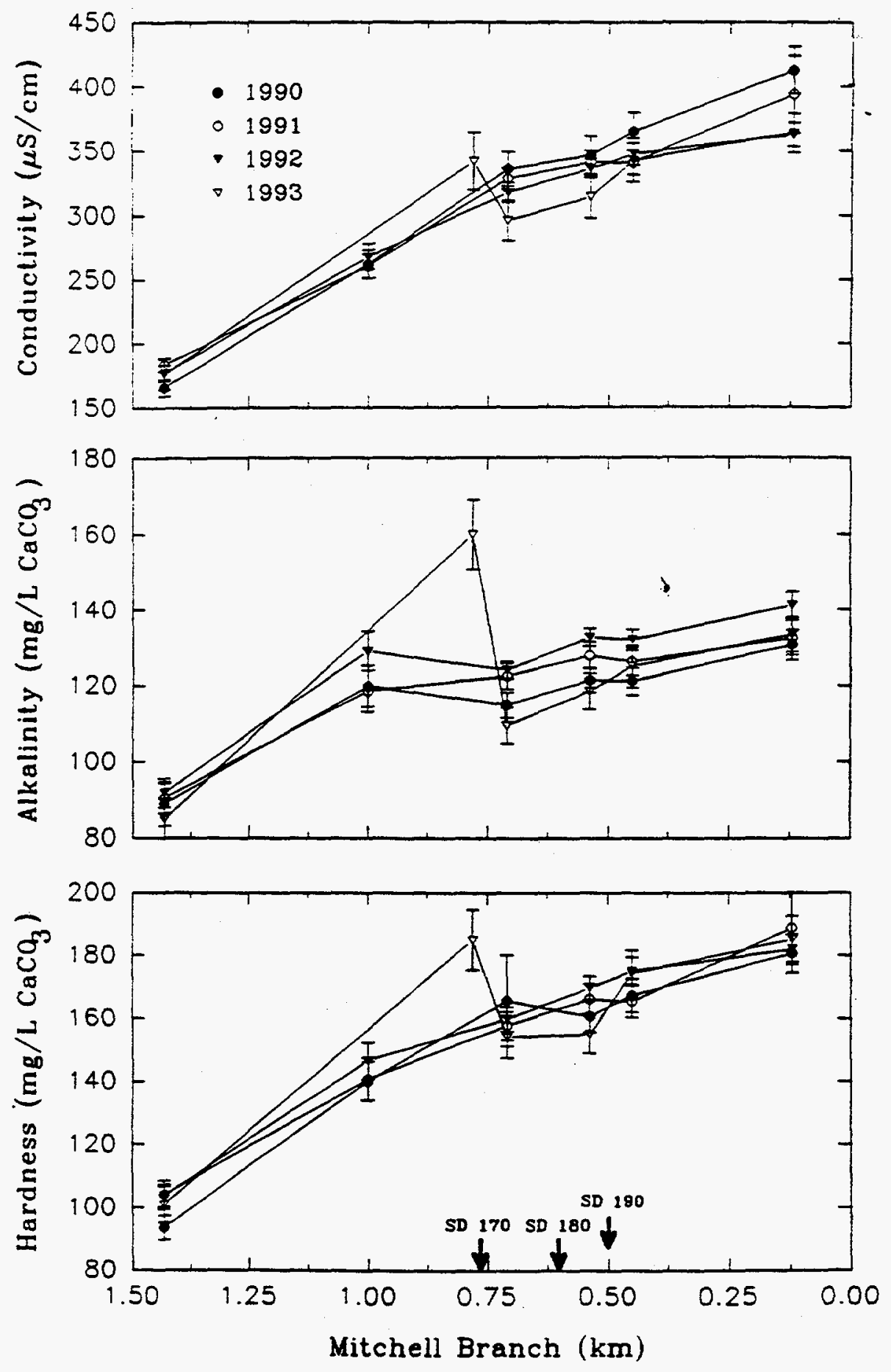

Fig. 3.1. Annual mean conductivity, alkalinity and hardness for each site in Mitchell Branch, 1990-1993. Vertical bars represent $\pm 1 \mathrm{SE}$. $\mathrm{SD}=$ storm drain. 

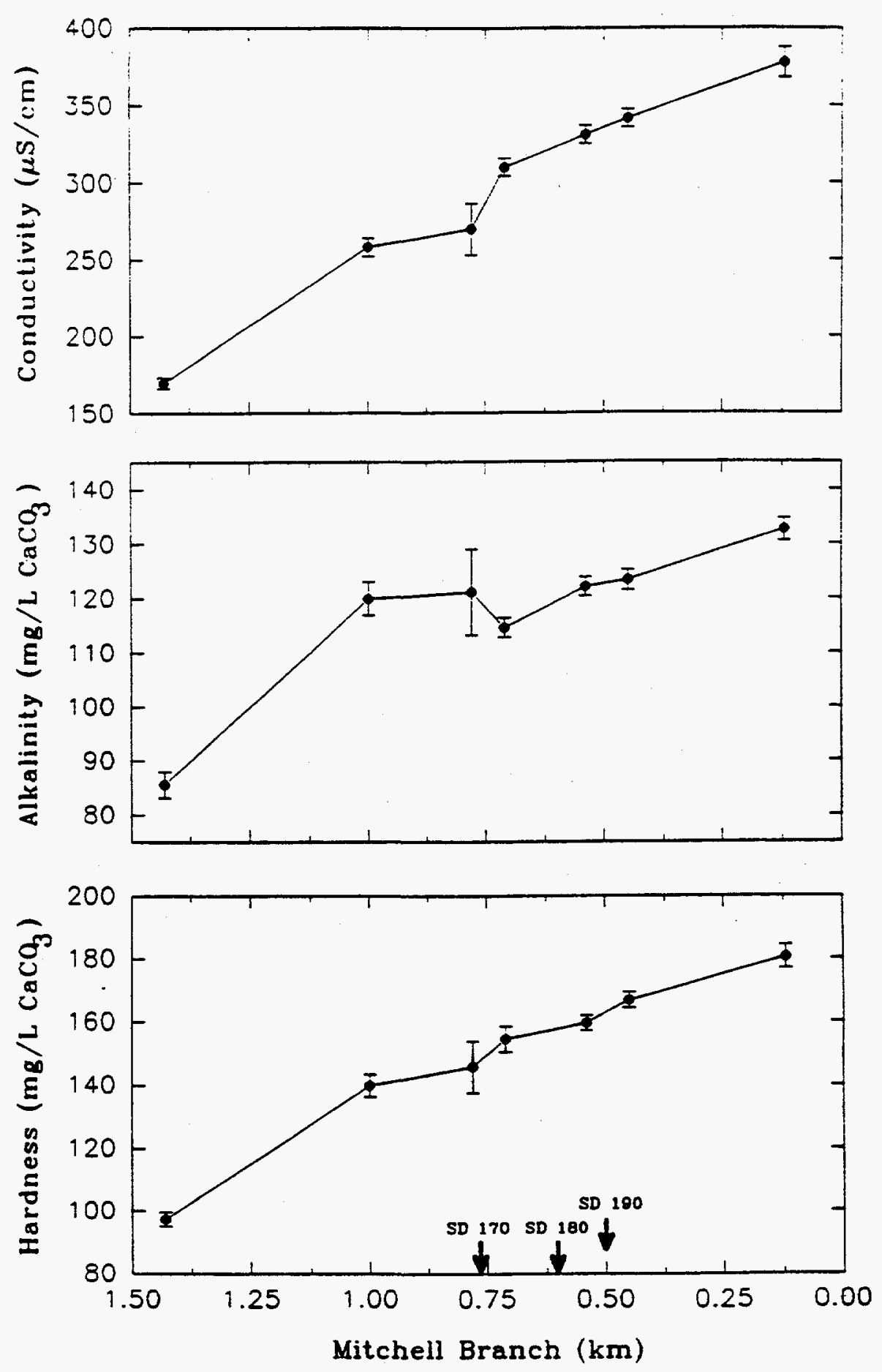

Fig. 3.2. Multi-year mean conductivity, alkalinity and hardness for each site in Mitchell Branch. Values are for tests conducted January 1990 to January 1994 . Vertical bars represent \pm 1 SE. $S D=$ storm drain. 
Alkalinity increased from approximately $90 \mathrm{mg} / \mathrm{L}$ at MK 1.43 to $120 \mathrm{mg} / \mathrm{L}$ at MIK 0.12 (Fig. 3.1 and 3.2). Alkalinity (each year and for all test dates combined; Table 3.6) was not different from MIK 1.0 downstream to MIK 0.12 with the exception of MIK 0.78 in 1993 (Figs. 3.1 and 3.2). Alkalinity at MIK 0.78 was significantly higher than at all sites except MIK 0.12 .

Table 3.6. Tukey groupings for conductivity and hardness for tests completed during 1990-1994

\begin{tabular}{|c|c|c|c|c|c|c|c|c|c|c|}
\hline Site & \multicolumn{5}{|c|}{ Conductivity } & \multicolumn{5}{|c|}{ Hardness } \\
\hline 1.43 & $A$ & & & & & A & & & & \\
\hline 1.00 & B & & & & & & B & & & \\
\hline 0.78 & B & C & & & & & B & C & & \\
\hline 0.71 & & C & $\mathrm{D}$ & & & & & C & D & \\
\hline 0.54 & & & D & $\mathrm{E}$ & & & & C & D & \\
\hline 0.45 & & & & E & & & & & $\mathrm{D}$ & \\
\hline 0.12 & & & & & $F$ & & & & & $\mathbf{E}$ \\
\hline
\end{tabular}

Note: Sides with the same letter are not significantly different. MIK = Mitchell Branch kilometer

Hardness increased from approximately $100 \mathrm{mg} / \mathrm{L}$ at MIK 1.43 to $170 \mathrm{mg} / \mathrm{L}$ at $\mathrm{MIK} 0.12$ (Figs 3.1 and 3.2). During 1990 and 1991, hardness at MIK 1.0 was significantly lower than at MIK 0.12 but not different from the remaining sites downstream (MIK 0.71 to MIK 0.45 ), and hardness at MIK 0.12 was not different from the three sites upstream (MIKs $0.45,0.54$, and 0.71). The comparison of hardness for all test dates (Table 3.6) showed that MTK 0.12 could be distinguished from all sites; however, differences in hardness were not significantly different from MIK 0.78 downstream to MIK 0.54 and from MIK 0.71 downstream to MIK 0.45. Hardness was not different between MIK 1.0 and MIK 0.78 .

TRC measured at each site is shown in Table 3.5. From January to November 1990, TRC was present at all sites from MIK 0.71 downstream to MIK 0.12. For example, maximum TRC at MIK 0.71 ranged from 0.00 to $0.78 \mathrm{mg} / \mathrm{L}$. Maximum TRC at MIK 0.45 ranged from 0.03 to $0.47 \mathrm{mg} / \mathrm{L}$. From January 1991 to November 1991, maximum TRC was 
above $0.06 \mathrm{mg} / \mathrm{L}$ only once at MIK 0.45 . Measurements taken after November 1991 are not shown in Table 3.5 because TRC was never greater than $0.03 \mathrm{mg} / \mathrm{L}$.

\section{Poplar Creek and Clinch River}

Mean $\mathrm{pH}$, alkalinity, hardness, and conductivity for each test and site from 1990 to 94 are provided in Appendix B (Table B.1). Mean water quality changed very little with distance downstream in Poplar Creek with the exception of the test conducted in April 1993. Mean alkalinity, hardness, and conductivity were lower at all sites in April 1993 and January 1994 as compared with July and October 1993. In April 1993 and January 1994, alkalinity ranged from about 40 to $70 \mathrm{mg} / \mathrm{L}$ for the Poplar Creek sites and averaged about $100 \mathrm{mg} / \mathrm{L}$ for the Clinch River site; hardness ranged from about 70 to $130 \mathrm{mg} / \mathrm{L}$ for the Poplar Creek sites and 125 to $150 \mathrm{mg} / \mathrm{L}$ for the Clinch River site; conductivity ranged from about 160 to $225 \mu \mathrm{S} / \mathrm{cm}$ for the Poplar Creek sites and about 255 to $260 \mu \mathrm{S} / \mathrm{cm}$ for the Clinch River site. In July and October 1993, alkalinity ranged from about 112 to $140 \mathrm{mg} / \mathrm{L}$ for the Poplar Creek and Clinch River sites; hardness ranged from about 150 to $190 \mathrm{mg} / \mathrm{L}$ for the Poplar Creek and Clinch River sites; conductivity ranged from about 250 to $375 \mu \mathrm{S} / \mathrm{cm}$ for the Poplar Creek and Clinch River sites.

\subsubsection{Fathead minnow tests}

\section{Mitchell Branch}

Survival and growth of fathead minnows in water from each site and each test are presented in Appendix B (Table B.2). Mean survival and growth in minnows in water from each site in each year are plotted in Fig. 3.3. Results for 1987-89 are presented in Kszos (1993, 1994). As in previous years, minnow survival in water from the reference site (MIK 1.43) was low (about 60\%) during each year. At MIK 1.0, mean survival was also low each year (about 60\%), compared with other sites and compared with 1987-89, when mean survival was about 80 to $90 \%$. Mean survival at MIKs $0.78,0.71,0.54,0.45$, and 0.12 was about $90 \%$ in each year with the exception of low mean survival (60\%) at MIK 0.45 in 1990. This low mean survival was because of two tests in which none of the minnows survived. Mean survival at MIK 0.71 and MIK 0.45 is artificially elevated because one test at each site was not conducted when TRC was high enough to have killed all the test organisms on the first day of the test. Thus, had the tests been conducted, mean survival at these sites would be 

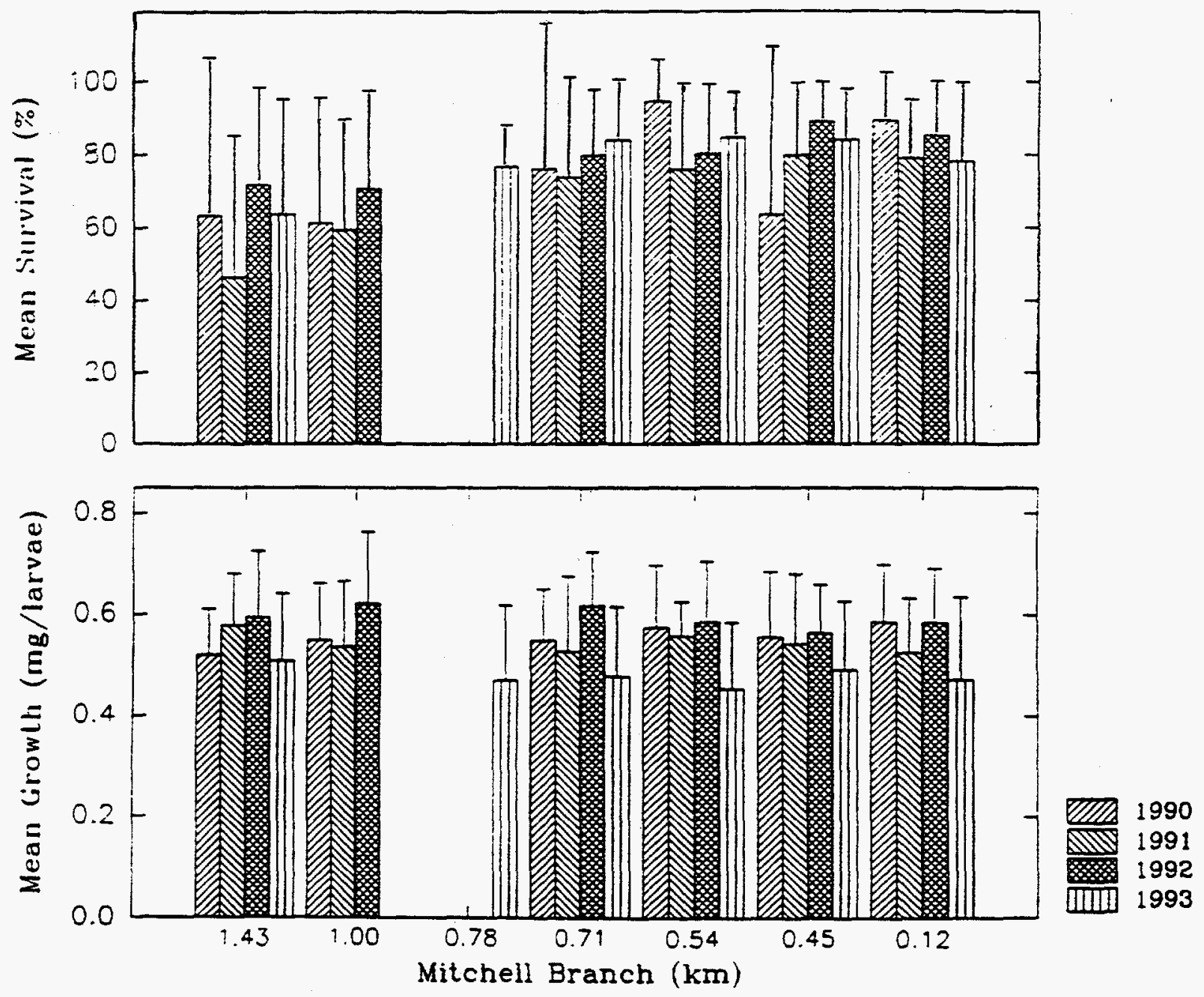

Fig. 3.3. Mean percentage survival (a) and growth (b) of fathead minnows in Mitchell Branch, 1990-1993. Vertical bars represent \pm SD. 
closer to $70 \%$. Mean growth between sites in each year was similar and was lower at all sites in 1993. Significant differences in survival and growth are presented in Table 3.7. No toxicity to fathead minnows occurred in 95 of 106 test/site combinations. Acute toxicity occurred once at MIK 0.71 and twice at MIK 0.45 in 1990. Chronic toxicity was found in 5 of 106 test/site combinations: 3 times at MIK 1.00 in 1990, 1 time at MIK 0.71 in 1993, and 1 time each at MIK 0.54 and MIK 0.45 in 1992.

\section{Poplar Creek and Clinch River}

Survival and growth of fathead minnows in water from each site and for each test are presented in Appendix B (Table B.2). Minnow survival and growth in water from each site were never significantly lower than that in the reference site (PCK 18.2).

\subsubsection{Ceriodaphnia tests}

\section{Mitchell Branch}

Survival and reproduction of Ceriodaphnia in water from each site and for each test are presented in Appendix B (Table B.2). Mean survival and reproduction in water from each site in each year are plotted in Fig. 3.4. Results for 1987-89 are presented in Kszos (1993, 1994). Mean survival and reproduction at MIKs 1.43 and 1.00 were consistently high. Mean survival at MIKs $0.71,0.54$, and 0.45 was the lowest (about 40\%) during 1990. From 1990 to 1993, survival at all sites was $\geq 70 \%$. Mean reproduction at all sites from MIK 0.71 downstream to MIK 0.12 was lower in 1990 and 1992 than in 1991 or 1993. Significant differences in survival and reproduction are presented in Table 3.7. No toxicity to Ceriodaphnia occurred in 78 of 108 test/site combinations. Acute toxicity occurred in 14 of 108 test/site combinations with 11 of the 18 occurring during 1990 (three times each at MIK 0.71 and MIK 0.54, four times at MIK 0.45 , and once at MIK 0.12). Chronic toxicity was found in 15 of 108 test/site combinations with 10 of the 15 occurring at MIKs $0.71,0.54$, and 0.45 during 1992 . The only incidence of chronic toxicity in 1993 occurred at MIK 0.71 .

\section{Poplar Creek and Clinch River}

Survival and reproduction of Ceriodaphnia in water from each site and for each test are presented in Appendix B (Table B.2). Ceriodaphnia survival and reproduction in water from each site were never significantly lower than the reference site (PCK 18.2). 
Table 3.7. Number of fathead minnow and Ceriodaphnia tests where no toxicity, acute toxicity or chronic toxicity was observed for Mitchell Branch sites

\begin{tabular}{|c|c|c|c|c|c|c|c|c|}
\hline \multirow[b]{2}{*}{ Site (MIK) } & \multirow[b]{2}{*}{ Year } & \multirow[b]{2}{*}{$n^{d}$} & \multicolumn{2}{|c|}{ No Toxicity ${ }^{a}$} & \multicolumn{2}{|c|}{ Acute Toxicity ${ }^{b}$} & \multicolumn{2}{|c|}{ Chronic Toxicity } \\
\hline & & & FHM & $\mathrm{CD}$ & FHM & $\mathrm{CD}$ & FHM & $\mathrm{CD}$ \\
\hline \multirow[t]{5}{*}{1.00} & 1990 & 6 & 3 & 6 & 0 & 0 & 3 & 0 \\
\hline & 1991 & $4 / 5$ & 3 & 5 & 0 & 0 & 1 & 0 \\
\hline & 1992 & 6 & 5 & 6 & 0 & 0 & 1 & 0 \\
\hline & 1993 & 1 & 1 & 1 & 0 & 0 & 0 & 0 \\
\hline & All & $17 / 18$ & 12 & 18 & 0 & 0 & 4 & 0 \\
\hline 0.78 & 1993 & 3 & 3 & 3 & 0 & 0 & 0 & 0 \\
\hline \multirow[t]{5}{*}{0.71} & 1990 & $5^{e}$ & 4 & 2 & 1 & 3 & 0 & 0 \\
\hline & 1991 & 6 & 6 & 5 & 0 & 0 & 0 & 1 \\
\hline & 1992 & 6 & 6 & 1 & 0 & 1 & 0 & 4 \\
\hline & 1993 & 4 & 4 & 2 & 0 & 1 & 0 & 1 \\
\hline & All & 21 & 20 & 10 & 1 & 5 & 0 & 6 \\
\hline \multirow[t]{5}{*}{0.54} & 1990 & $5^{e} / 6$ & 5 & 3 & 0 & 3 & 0 & 1 \\
\hline & 1991 & 6 & 6 & 6 & 0 & 0 & 0 & 0 \\
\hline & 1992 & 6 & 5 & 1 & 0 & 1 & 1 & 4 \\
\hline & 1993 & 4 & 4 & 4 & 0 & 0 & 0 & 0 \\
\hline & All & $21 / 22$ & 20 & 14 & 0 & 4 & 1 & 5 \\
\hline \multirow[t]{5}{*}{0.45} & 1990 & 6 & 4 & 2 & 2 & 4 & 0 & 0 \\
\hline & 1991 & 6 & 6 & 6 & 0 & 0 & 0 & 0 \\
\hline & 1992 & 6 & 6 & 4 & 0 & 0 & 0 & 2 \\
\hline & 1993 & 4 & 4 & 4 & 0 & 0 & 0 & 0 \\
\hline & All & 22 & 20 & 16 & 2 & 4 & 0 & 2 \\
\hline \multirow[t]{5}{*}{0.12} & 1990 & 6 & 6 & 5 & 0 & 1 & 0 & 0 \\
\hline & 1991 & 6 & 6 & 6 & 0 & 0 & 0 & 0 \\
\hline & 1992 & 6 & 6 & 4 & 0 & 0 & 0 & 2 \\
\hline & 1993 & 4 & 4 & 4 & 0 & 0 & 0 & 0 \\
\hline & All & 22 & 22 & 18 & 0 & 1 & 0 & 2 \\
\hline
\end{tabular}

Note: MIK $=$ Mitchell Branch kilometer; FHM = fathead minnow; $\mathrm{CD}=$ Ceriodaphnia dubia .

${ }^{a}$ There was no significant reduction in minnow survival or growth or Ceriodaphnia survival or reproduction.

${ }^{b}$ Survival $\leq 20 \%$ in $48 \mathrm{~h}$.

${ }^{c}$ Minnow survival or growth significantly reduced compared to laboratory control or Ceriodaphnia survival or reproduction significantly reduced compared to reference site.

${ }_{\mathrm{n}}=$ number of tests given for both species or as fathead minnow/Ceriodaphnia.

${ }^{e}$ Test was not completed because total residual chlorine would have killed all organisms on the first day of the test 

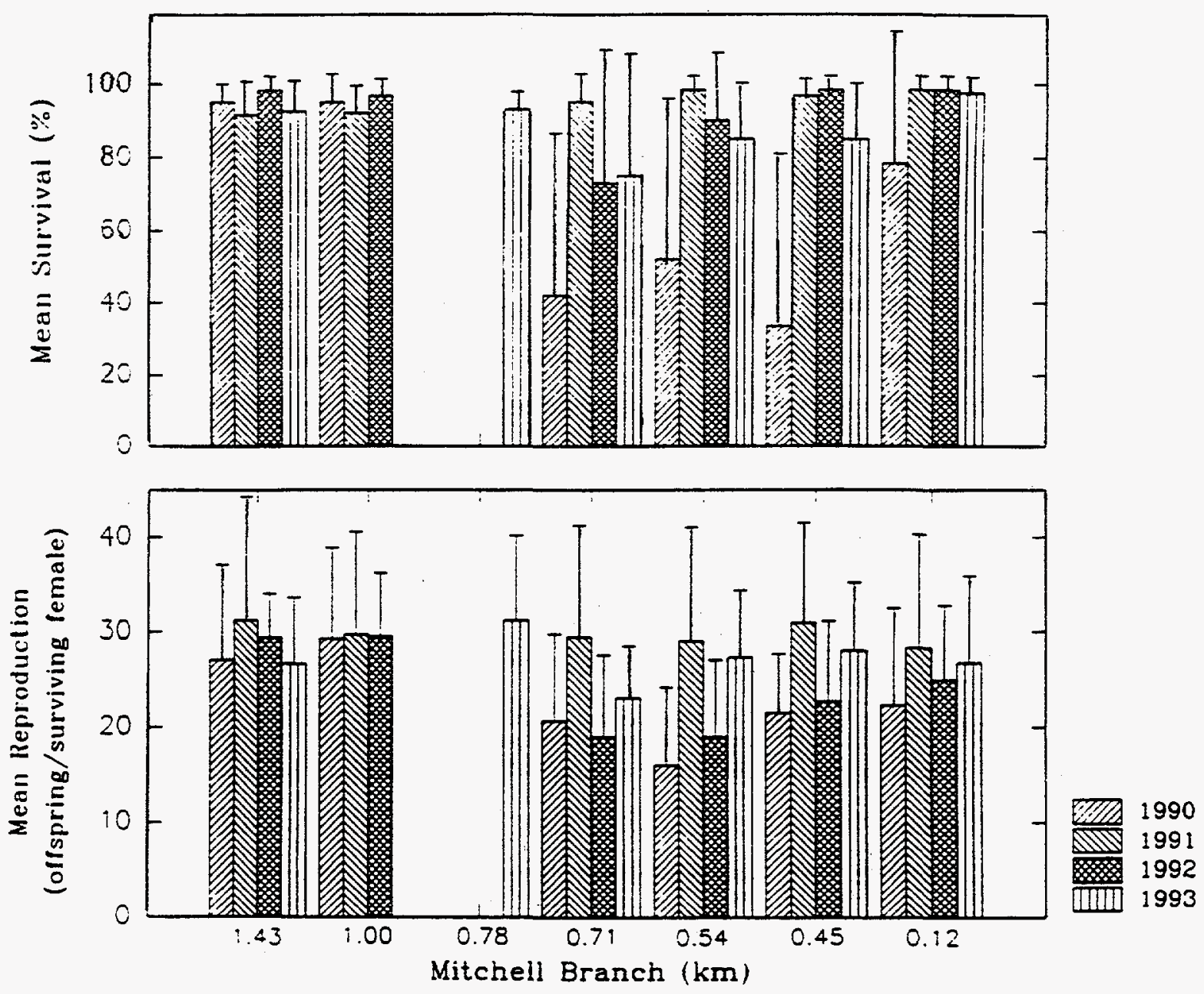

Fig. 3.4. Mean percentage survival (a) and reproduction (b) of Ceriodaphnia for each site in Mitchell Branch, 1990-1993. Vertical bars represent \pm SD. 


\subsubsection{Discussion}

The K-25 Site successfully eliminated the acute toxicity of water from Mitchell Branch to fathead minnows and Ceriodaphnia with the dechlorination of the storm drain effluents in 1991 at the NPDES discharge points. This is evidenced by the dramatic reduction in concentrations of TRC coincident with a near elimination of acute toxicity. However, the ambient toxicity test data and results of the storm drain toxicity tests indicate that the effluent from SDs 170 and 190 continues to adversely impact Mitchell Branch. Although the majority of tests for Mitchell Branch sites show no chronic toxicity, Ceriodaphnia reproduction has been reduced at MIKs 0.71 (below SD 170), 0.54 (below SD 180), 0.45 (below SD 190) and MIK 0.12 fifteen times in 1992-93. In addition, chronic toxicity at SDs 170 and 190 is the norm for tests conducted in 1993-94.

Ceriodaphnia have been shown to be more sensitive than fathead minnows to water from all of the ambient sites except MIK 1.0. In each case where toxicity to fathead minnows was observed, toxicity to Ceriodaphnia was also observed. In other cases, no toxicity to fathead minnows was observed but Ceriodaphnia survival and/or reproduction was reduced. As in previous years, minnow survival at MIK 1.43 remains low, indicating that this site is an inappropriate reference site for ambient toxicity tests with fathead minnows. It remains our hypothesis that the toxicity at MIK 1.43 is due to a natural pathogen rather than an anthropogenic input (cf. Kszos 1993, 1994; Stewart 1994). Evidence which supports this hypothesis includes (1) lack of toxicity in samples treated with ultraviolet light or filtration, (2) high beaker to beaker variability in minnow survival and (3) low mean survival and beaker to beaker variability in water from non-contaminated reference sites (Kszos and Stewart 1992). Due to the higher sensitivity of the Ceriodaphnia and the low minnow survival at MIK 1.43, subsequent ambient toxicity tests will be conducted with only Ceriodaphnia. Because toxicity is rarely present at SD 180 , testing at this storm drain will be reduced to several times per year. These changes will allow us to concentrate on (1) investigating the source(s) of toxicity in SDs 170 and 190, (2) increase the frequency of testing at Mitchell Branch sites from four times per year to six, (3) conduct tests of Mitchell Branch and the storm drains concurrently, and (4) continue to investigate potential sources of toxicity from other storm drains.

The magnitude of the increases in conductivity, alkalinity, and hardness with distance downstream in Mitchell Branch have remained the same during 1990-93. Analyses of water 
chemistry data indicates that the increase in conductivity and hardness is due to cumulative inputs from the K-25 Site rather than substantial input from one particular storm drain.

Chemically, MIKs 1.43 and 0.12 could be distinguished from all other sites but adjacent sites could not be distinguished from each other (e.g., MIK 0.45 and MIK 0.54). During 1990-91, concentrations of TRC in water from MIKs $0.71,0.54$, and 0.45 frequently exceeded the EPA water quality criteria for chronic exposure of $0.011 \mathrm{mg} / \mathrm{L}$ (EPA 1986b). Since November 1991, TRC concentrations have typically been $0.0 \mathrm{mg} / \mathrm{L}$.

Toxicity tests of water from Poplar Creek and Clinch River were conducted for the first time during 1993. Water quality data indicate that at least two different flow conditions were evaluated for Poplar Creek. In April 1993 and January 1994, mean alkalinity, hardness, and conductivity were lower at all sites than in July and October 1993. For all tests conducted, no toxicity was evident in water from any site. The water chemistry and toxicity data provide no evidence that effluents entering via Mitchell Branch (enters Poplar Creek above PCK 6.9) or CNF (enters Poplar Creek above PCK 4.7) impact Poplar Creek. In addition, the toxicity tests do not detect any impact from the Power House area (above PCK 1.6). Toxicity tests of water from Poplar Creek and Clinch River will therefore be discontinued. 


\section{BIOACCUMULATION STUDIES (TASK 2)}

M. J. Peterson, G. R. Southworth, B. G. Blaylock,

B. R. O'Neal, D. K. Cox, and T. L. Ashwood

During the period 1987-92, bioaccumulation monitoring for the K-25 Site BMAP focused on the extent of contamination in aquatic biota in Mitchell Branch and nearby waters of Poplar Creek. In 1993, to address modifications cited in the new (1992) NPDES permit, the bioaccumulation monitoring task increased in scope to evaluate potential biological contamination in other aquatic habitats associated with the K-25 Site and to assess contamination in the terrestrial environment.

The bioaccumulation studies task has four primary objectives: (1) identify contaminants that accumulate in biota, (2) determine the degree of contamination, (3) identify and evaluate contaminant sources and (4) evaluate spatial and temporal changes in biotic contamination as a measure of the success of remedial actions. This task has two components: contaminant accumulation in aquatic biota (subtask 2a), and contaminant accumulation in terrestrial biota (subtask 2b).

\subsection{CONTAMINANT ACCUMULATION IN AQUATIC BIOTA (SUBTASK 2a) (M. J. Peterson and G. R. Southworth)}

\subsubsection{Introduction}

The results presented in previous BMAP reports (Smith et al. 1993, 1994) encompassed monitoring activities at the K-25 site from 1987 to 1990 . Mercury and polychlorinated biphenyls (PCBs) in fish and clams at sites near the K-25 Site were higher than levels found in fish and clams at two reference streams. Although Mitchell Branch was a likely source of PCBs to biota in Poplar Creek, the PCB contribution from Mitchell Branch appeared to be small relative to other possible sources (i.e., East Fork Poplar Creek and Bear Creek inputs and Poplar Creek sediments).

Mercury was clearly elevated in Mitchell Branch fish; however, levels were below the FDA action level of $1.0 \mu \mathrm{g} / \mathrm{g}$ (FDA 1984b) and the EPA's interim recommended screening value of $0.6 \mu \mathrm{g} / \mathrm{g}$ (EPA 1993). The close proximity of the Mitchell Branch site to Poplar Creek, coupled with the similar mercury concentrations (after size adjustment) in fish from the two systems, suggested that fish collected from Mitchell Branch may have migrated from 
mercury-contaminated Poplar Creek. The significance of Mitchell Branch as a source of mercury contamination to its own biota, or to biota in downstream waters, was unresolved.

In 1991 and 1992, bioaccumulation monitoring efforts continued to focus on Mitchell Branch and nearby waters of Poplar Creek with little change from past years. The exception was a special study using caged dace in 1992 that attempted to evaluate the significance of Mitchell Branch as source of mercury contamination to its resident biota. In 1993, to address modifications cited in the new (1992) NPDES permit, monitoring increased in scope to evaluate potential biological contamination in other aquatic habitats associated with the K-25 Site. A contaminant screening study was implemented to assess the bioaccumulation of a wide range of contaminants at various locations, including at some ponds near the K-25 Site that had not been previously sampled. Resident fish and transplanted clams were the primary monitoring tools used to assess biotic contamination. In spring 1993, to monitor spatial and temporal trends in mercury and PCB contamination, sunfish were sampled at an expanded number of sites on Poplar Creek and the Clinch River.

\subsubsection{Methods}

Sunfish were collected by electrofishing from Mitchell Branch (MIK 0.2) and two nearby sites on Poplar Creek (PCKs 6.9 and 8.2) once yearly from 1987 to 1992 . For comparison, sunfish were also collected from an uncontaminated reference stream, Hinds Creek. Sunfish from additional sites on Poplar Creek (PCKs 10.4 and 1.6) and the Clinch River (CRK 15.0) were sampled during this time, but less frequently. For each monitoring period, fish from Mitchell Branch were also analyzed for a suite of other metals, and asiatic caged clams were placed in Mitchell Branch to monitor organic contaminants. Clams are used because they provide a time-averaged measure of current exposure, and because they have been shown to be effective monitors of organic compounds that are more readily metabolized and excreted (and therefore accumulated) by fish.

In 1993, monitoring of mercury and PCB contamination in sunfish continued at sites monitored in past years (CRK 15.0, MIK 0.2, PCK 1.6, PCK 6.9, and PCK 8.2), with the addition of a site upstream of any K-25 Site impacts (PCK 18.2). Fish were collected from PCK 1.6, PCK 18.2, MIK 0.2, and three ponded tributaries of Poplar Creek (K-1007-P1, $\mathrm{K}-1007-\mathrm{P5}$, and $\mathrm{K}-710 \mathrm{~A}$ ponds) to be analyzed for a variety of metals in addition to mercury and PCBs. To assess the presence of organic contaminants, caged asiatic clams were placed in 
Mitchell Branch (MIK 0.2), Poplar Creek (PCKs 18.2 and 1.6), and the K-1007-P1 and K-710A ponds.

Bluegill (Lepomis macrochirus) was the primary fish species utilized to track mercury and PCB contamination in Poplar Creek and the Clinch River. In Mitchell Branch, where bluegill were not abundant, redbreast sunfish were used. Eight sunfish were analyzed individually for mercury and PCBs at each site. At each site where fish were analyzed for metals other than mercury, four bluegill comprised the collection for metals analysis. Four largemouth bass (Micropterus salmoides) were collected from each pond site for PCB analysis, except at the K-1007-P5 pond where only two bass were available. (Four bluegill were used to supplement the collection.) Largemouth bass were chosen for screening PCB contamination in the ponds because this species is a lipid-rich game fish that is most likely to represent the maximum level of PCBs in pond fish. Eight channel catfish were collected from both PCK 6.9 and CRK 15.0 for PCB analysis as part of continued off-site monitoring conducted jointly by the Y-12, K-25, and ORNL BMAPs.

An attempt was made to restrict collections to individuals of a size likely to be taken by sport fisherman ( $>40 \mathrm{~g}$ for sunfish, $>400 \mathrm{~g}$ for largemouth bass and channel catfish).

Reference fish were obtained from Hinds Creek and from two sites upstream of DOE impacts: upper Poplar Creek (PCK 18.2) and Melton Hill Reservoir (MHR; catfish reference site).

Upon collection, sunfish from all sites were tagged with a unique four-digit tag wired to the lower jaw and placed on ice in a labelled ice chest; the chest was locked for transport to the laboratory. Upon return to the laboratory, each fish was weighed, measured (total length), skinned and fileted. For mercury determination, a $1-$ to $2-\mathrm{g}$ portion of the anterior dorsal axial muscle filet was excised. A 5-g portion of the remaining tissue was used for analysis of PCBs and/or other metals. Largemouth bass and channel catfish (Ictalurus punctatus) were handled and processed as sunfish were, except that fish filets were frozen and ground three times in a hand-powered meat grinder before a $10-$ to $20-\mathrm{g}$ sample was removed for PCB analysis. All samples were wrapped in heavy-duty aluminum foil, labelled and stored at $-20^{\circ} \mathrm{C}$ in a locked freezer in Building 1505 at ORNL until delivered to the Analytical Services Organization (ASO) laboratory at ORNL.

To evaluate Mitchell Branch as a source of mercury to its own biota (see Sect. 4.1.3.1), blacknose dace (Rhinichthys atratulus, a common minnow of small streams in eastern North America) collected from an uncontaminated reference stream (Hinds Creek) were stocked in 
cages and placed in Mitchell Branch (MIK 0.6). A similar evaluation of potential mercury sources was conducted concurrently at two sites on Bear Creek (BCK 4.5 and BCK 12.0). For comparison, caged blacknose dace were also placed in an uncontaminated tributary of the same Poplar Creek system [Pin Hook Creek (PHK 1.6)], in a known mercury-contaminated stream [East Fork Poplar Creek (EFK 23.4)], and in a laboratory tank with no food source.

Twelve blacknose dace $(6-8 \mathrm{~cm}$ total length) were divided among three cages (four fish per cage) and placed at each site beginning in May 1992. Damaged cages at EFK 23.4 and BCK 11.0 necessitated that the monitoring period begin in August 1992 at these two sites. At the end of a 12-week exposure period, the muscle tissue (including a small amount of bone) of two blacknose dace from each cage, if possible, was analyzed for total mercury ( $n=6$ for each site) by ASO. Six resident blacknose dace from each site were also analyzed, as well as 12 fish from the reference stream, to obtain baseline values. To help assess blacknose dace condition during confinement, mortality and growth in length and weight were measured in dace over the 12-week exposure periods.

Asiatic clams were obtained in May 1991 from Bull Run Creek in Union County, Tennessee, and in June 1992 and June 1993 from Little Sewee Creek in Meigs County, Tennessee. After the clams were held for $24 \mathrm{~h}$ in the laboratory in dechlorinated process water, they were put in polypropylene cages that were held securely at each monitoring site. One set of clams from the reference stream was frozen immediately for analysis as a control. Each cage held approximately 50 clams, each of which contained 0.5-2 g (wet wt) of soft tissue. The clams were suspended in the stream for four weeks, at which time they were removed, placed on ice in a locked cooler, transported to the laboratory and deposited in a locked freezer in Building 1505 at ORNL. After the clams were frozen, the shells were removed and the frozen soft tissue was placed in a 20-ml glass vial. Duplicate composite samples weighing approximately $20 \mathrm{~g}$ were taken for organic priority pollutant analyses. The samples were later delivered to the ORNL ASO for analysis.

Total mercury determinations were conducted by cold vapor atomic adsorption spectrometry as described in EPA (1991). Previous studies (Southworth et al. 1994, Bloom 1992, Huckabee et al. 1979) have shown that the mercury content in fish muscle generally is greater than $90 \%$ methylmercury (the most toxic mercury species). Other metals were determined using inductively-coupled argon plasma emission spectroscopy or inductively coupled plasma/mass spectroscopy (EPA 1980, 1991). Organic priority pollutants were 
analyzed by procedure PPB 12/83 (EPA 1984) in which the homogenized sample is extracted in methylene chloride, cleaned up using column chromatography, and analyzed by gas chromatography and mass spectrometry (GC/MS) or by gas chromatography with electron capture detectors (GC/ECD). Determinations of chlorinated pesticides were made by capillary column GC/ECD using a method based on EPA procedure PPB 12/83 (EPA 1984), which involves homogenization of the sample in anhydrous sodium sulfate, extraction with methylene chloride, cleanup using column chromatography, and GC/ECD.

Quality assurance was maintained using a combination of duplicate analyses (submission of two subsamples from the same individual fish); the analysis of biological reference standards; and the analysis of uncontaminated fish. Recoveries of representative organics were verified by spiking uncontaminated fish or clam samples with known amounts and analyzing them.

Statistical evaluations of data were made using SAS procedures and software (SAS 1985a, 1985b) for ANOVA, Tukey's multiple comparison test, and calculation of the mean, $\mathrm{SD}$, standard error (SE), and CV. Tests for homogeneity of variance among various data groups were conducted using Levene's test on untransformed and $\log _{\mathrm{e}}$-transformed variables (Sokal and Rohlf 1981). Comparisons were based on untransformed data unless Levene's test indicated that transformation was needed to meet assumptions of homogeneous variances. Dunnett's test was used to compare means of various groups with controls (Zar 1984). All comparisons were conducted using $p=0.05$.

\subsubsection{Results and Discussion}

\subsubsection{Mercury in Mitchell Branch fish}

\section{Sunfish}

Mercury was clearly elevated in fish from Mitchell Branch compared with fish from the reference stream, averaging two to three times higher than the reference stream in each year from 1991 to 1993 (Table 4.1; Table C.1). Concentrations in Mitchell Branch fish were below EPA's interim screening value of $0.6 \mu \mathrm{g} / \mathrm{g}$ for mercury in fish tissue (EPA 1993) and the FDA action level of $1.0 \mu \mathrm{g} / \mathrm{g}$ (FDA 1984b). However, five fish from Mitchell Branch exceeded the conservative Preliminary Guidance Value (PGV) for mercury of $0.42 \mu \mathrm{g} / \mathrm{g}$ (Travis et al. 1986).

Mean mercury concentrations in Mitchell Branch redbreast sunfish have remained stable $(0.25-0.33 \mu \mathrm{g} / \mathrm{g}$; Table 4.1$)$ over the $1990-93$ period. Average mercury concentration were 
Table 4.1. Mercury concentrations (in micrograms per gram, wet weight) in bluegill (Lepomis macrochirus) and redbreast sunfish ( $L$ auritus) collected from Mitchell Branch, Poplar Creek and the Clinch River, 1987-1993

\begin{tabular}{|c|c|c|c|c|c|}
\hline Site $^{a}$ & Species & Date & $\begin{array}{c}\mathrm{Hg} \\
\text { mean } \pm 1 \mathrm{SE}\end{array}$ & Range & $\begin{array}{c}\text { EPA } \\
\text { exceedences }^{b}\end{array}$ \\
\hline PCK 18.2 & Bluegill & March 1993 & $0.06 \pm 0.01$ & $0.04-0.12$ & $0 / 8$ \\
\hline PCK 10.4 & Bluegill & $\begin{array}{l}\text { November } 1987 \\
\text { November } 1988 \\
\text { December } 1989\end{array}$ & $\begin{array}{l}0.10 \pm 0.03 \\
0.08 \pm 0.03 \\
0.18 \pm 0.01\end{array}$ & $\begin{array}{l}0.05-0.16 \\
0.02-0.24 \\
0.04-0.62\end{array}$ & $\begin{array}{l}0 / 8 \\
0 / 8 \\
1 / 8\end{array}$ \\
\hline PCK 8.2 & Bluegill & $\begin{array}{l}\text { November } 1987 \\
\text { November } 1988 \\
\text { November } 1989 \\
\text { March } 1990 \\
\text { January } 1991 \\
\text { July } 1992 \\
\text { March } 1993\end{array}$ & $\begin{array}{l}0.43 \pm 0.06 \\
0.41 \pm 0.05 \\
0.57 \pm 0.07 \\
0.36 \pm 0.05 \\
0.40 \pm 0.08 \\
0.38 \pm 0.04 \\
0.34 \pm 0.05\end{array}$ & $\begin{array}{l}0.21-0.69 \\
0.23-0.59 \\
0.20-0.88 \\
0.14-0.65 \\
0.07-0.71 \\
0.24-0.49 \\
0.15-0.55\end{array}$ & $\begin{array}{l}2 / 8 \\
0 / 8 \\
4 / 8 \\
1 / 8 \\
1 / 8 \\
0 / 8 \\
0 / 8\end{array}$ \\
\hline MIK 0.2 & Redbreast & $\begin{array}{l}\text { May } 1987 \\
\text { March } 1988 \\
\text { March } 1989 \\
\text { January } 1990 \\
\text { January } 1991 \\
\text { January } 1992 \\
\text { March } 1993\end{array}$ & $\begin{array}{l}0.17 \pm 0.01 \\
0.12 \pm 0.01 \\
0.19 \pm 0.01 \\
0.27 \pm 0.03 \\
0.32 \pm 0.05 \\
0.25 \pm 0.03 \\
0.33 \pm 0.03\end{array}$ & $\begin{array}{l}0.15-0.18 \\
0.09-0.14 \\
0.12-0.22 \\
0.11-0.39 \\
0.18-0.56 \\
0.19-0.48 \\
0.16-0.46\end{array}$ & $\begin{array}{l}0 / 7 \\
0 / 5 \\
0 / 8 \\
0 / 8 \\
0 / 8 \\
0 / 8 \\
0 / 8\end{array}$ \\
\hline PCK 6.9 & Bluegill & $\begin{array}{l}\text { June } 1987 \\
\text { November } 1987 \\
\text { November } 1988 \\
\text { December } 1989 \\
\text { March } 1990 \\
\text { January } 1991 \\
\text { July } 1992 \\
\text { March } 1993\end{array}$ & $\begin{array}{l}0.42 \pm 0.05 \\
0.43 \pm 0.05 \\
0.29 \pm 0.05 \\
0.62 \pm 0.04 \\
0.43 \pm 0.04 \\
0.37 \pm 0.06 \\
0.40 \pm 0.07 \\
0.36 \pm 0.03\end{array}$ & $\begin{array}{l}0.24-0.65 \\
0.26-0.66 \\
0.09-0.54 \\
0.38-0.75 \\
0.30-0.68 \\
0.15-0.67 \\
0.27-0.69 \\
0.29-0.48\end{array}$ & $\begin{array}{l}1 / 8 \\
1 / 8 \\
0 / 8 \\
6 / 8 \\
1 / 8 \\
1 / 8 \\
2 / 8 \\
0 / 8\end{array}$ \\
\hline PCK 1.6 & Bluegill & $\begin{array}{l}\text { December } 1987 \\
\text { November } 1988 \\
\text { March } 1993\end{array}$ & $\begin{array}{l}0.16 \pm 0.04 \\
0.17 \pm 0.02 \\
0.25 \pm 0.05\end{array}$ & $\begin{array}{l}0.06-0.35 \\
0.06-0.24 \\
0.07-0.44\end{array}$ & $\begin{array}{l}0 / 8 \\
0 / 8 \\
0 / 8\end{array}$ \\
\hline CRK 15.0 & Bluegill & $\begin{array}{l}\text { November } 1987 \\
\text { November } 1988 \\
\text { February } 1991 \\
\text { May } 1992 \\
\text { March } 1993\end{array}$ & $\begin{array}{l}0.14 \pm 0.03 \\
0.14 \pm 0.03 \\
0.20 \pm 0.03 \\
0.20 \pm 0.07 \\
0.18 \pm 0.03\end{array}$ & $\begin{array}{l}0.06-0.31 \\
0.02-0.28 \\
0.11-0.42 \\
0.09-0.71 \\
0.09-0.36\end{array}$ & $\begin{array}{l}0 / 8 \\
0 / 8 \\
0 / 8 \\
1 / 8 \\
0 / 8\end{array}$ \\
\hline Hinds Creek & $\begin{array}{l}\text { Redbreast' } \\
\text { Bluegill }\end{array}$ & $1991-1993$ & $0.11 \pm 0.01$ & $0.04-0.24$ & $0 / 21$ \\
\hline
\end{tabular}

a $\mathrm{PCK}=$ Poplar Creek kilometer; MIK = Mitchell Branch kilometer; CRK = Clinch River kilometer.

${ }^{b}$ Number of samples exceeding the EPA screening value for $\mathrm{Hg}$ of $0.6 \mathrm{ppm}$ (EPA 1993, Guidance for Assessing Chemical Contaminant Data for Use in Fish Advisories, Vol. 1, Fish Sampling and Analysis, U.S. Environmental Protection Agency, Washington, D.C.) divided by the total number of samples. 
lower in fish collected prior to 1990; however, collections from 1987 through 1989 were of substantially smaller fish, averaging 5 and $26 \mathrm{~g}$ in each year respectively. Accumulation of mercury in fish tends to increase with body size, thus the larger fish obtained since 1990 (average weight greater than $40 \mathrm{~g}$ in all years) would be expected to contain higher concentrations of mercury than the extremely small fish collected in the previous years. When linear regression analysis of mercury vs weight for previously collected MIK 0.2 sunfish was used to estimate the concentration of mercury in a hypothetical 70-g fish from Mitchell Branch, a value of $0.33 \mu \mathrm{g} / \mathrm{g}$ was obtained (Smith et al. 1994). This value is very close to the average concentration in current collections, suggesting that mercury contamination has not changed substantially in Mitchell Branch from 1987 to 1993.

\section{Blacknose Dace}

Although sunfish collected from Mitchell Branch contained elevated concentrations of mercury, the proximity and accessibility of Poplar Creek, in which sunfish contained similar concentrations of mercury, made it uncertain that Mitchell Branch was the source of mercury to those fish. Placement of uncontaminated, caged sunfish into Mitchell Branch was considered as a means of determining the extent of biologically-available mercury within the system. However, past attempts at caging sunfish in streams on the Oak Ridge Reservation yielded limited success: sunfish were highly territorial and did not tolerate confinement, and the relatively large cages were susceptibable to damage and wash-out during storms.

Although monitoring sediment or water in such streams may give insight into the contamination problem, these components may not be reliable predictors of the extent of mercury contamination in biota in the system, hence the need for biological monitoring (Rada and Findley 1986, Phillips et al. 1987, Loar 1989, Suchanek et al. 1993). Blacknose dace $(R$. atratulus), were used as bioindicators of mercury contamination in Mitchell Branch and other nearby streams during the summer/fall of 1992 . This species was chosen because (1) blacknose dace are common inhabitants of small creeks in east Tennessee and were abundant at all monitoring sites, (2) blacknose dace are omnivorous and adaptable in a caged environment, (3) mercury concentrations in muscle tissue of "forage" species such as blacknose dace may be more comparable to "sport fish" muscle concentrations (best suited for human risk analysis) than other biota such as macroinvertebrates or periphyton and (4) caged 
blacknose dace rapidly accumulated mercury in upper East Fork Poplar Creek in previous studies (Loar 1993).

The mercury results from the caged dace experiment were analyzed by combining all individual fish data obtained for each site [ $n=6$ at all sites except EFK $23.4(n=3)]$. Cage-to-cage variation in mercury concentrations within each site was low (except at EFK 23.4 where variability could not be evaluated); there was no significant difference in mercury concentrations in dace between cages at each site. Survival of caged blacknose dace after a 12-week exposure was $\geq 75 \%$ at all but EFK $23.4(25 \%)$ and the laboratory tank (58\%). A significant decrease in mean condition factor (wt/lgth $\left.{ }^{3} \times 100\right)$ occurred in caged dace after a 12-week exposure at all sites except EFK 23.4 (Table 4.2). Although the mean condition factor of resident dace from the uncontaminated reference stream (Hinds Creek) was also significantly lower after the 12-week period, the magnitude of the decrease at some sites suggests that food availability may have been limited in the caged treatments.

Mean mercury concentrations in caged blacknose dace after 12 weeks' exposure were low $(<0.20 \mu \mathrm{g} / \mathrm{g})$ at all sites monitored; however, concentrations of mercury in dace from Mitchell Branch, Bear Creek, and EFPC significantly exceeded those in dace from Hinds Creek, the baseline reference stream (Table 4.2). Caged blacknose dace from MIK 0.6 and from EFK 23.4 were also significantly higher in mercury than caged blacknose dace from an unimpacted tributary in the same watershed (PHK 1.6).

Mean mercury concentrations in resident blacknose dace from all monitored sites, including the unimpacted tributary, were significantly higher than that in fish from the baseline reference stream (log-transformed data; Table 4.2). Mercury concentrations in resident blacknose dace showed a site-to-site pattern similar to that of caged blacknose dace, but concentrations were significantly higher in resident blacknose dace than caged blacknose dace at all sites. As was the case with caged blacknose dace, mean mercury concentrations in resident blacknose dace were highest in Mitchell Branch and EFPC, with little difference between concentrations in Bear Creek fish and those from Pinhook Branch. The similar siteto-site pattern between caged and resident blacknose dace suggests that resident represent mercury exposure at the collection site. The difference in accumulation between 
Table 4.2. Mean mercury concentrations and condition factors in blacknose dace (Rhinichthys atratulus)

\begin{tabular}{|c|c|c|c|c|}
\hline \multirow[b]{2}{*}{ Site } & \multicolumn{2}{|c|}{$\begin{array}{l}\text { Mercury concentrations } \\
(\mu \mathrm{g} / \mathrm{g} \text {, wet wt) }\end{array}$} & \multicolumn{2}{|c|}{$\begin{array}{l}\text { Condition factors } \\
\text { (wt/vol.) }\end{array}$} \\
\hline & Caged dace & Resident dace & $\begin{array}{l}\text { Before cage } \\
\text { placement }\end{array}$ & $\begin{array}{l}\text { After 12-week } \\
\text { exposure }\end{array}$ \\
\hline EFK 23.4 & $\begin{array}{c}0.189 \pm 0.029 * \\
\text { (3) }\end{array}$ & $\begin{array}{c}0.367 \pm 0.025^{*} \\
(6)\end{array}$ & $\begin{array}{l}0.92 \pm 0.02 \\
\quad(12)\end{array}$ & $\begin{array}{c}0.95 \pm 0.06 \\
(3)\end{array}$ \\
\hline MIK 0.6 & $\begin{array}{c}0.144 \pm 0.024^{*} \\
(6)\end{array}$ & $\begin{array}{c}0.224 \pm 0.022^{*} \\
(6)\end{array}$ & $\begin{array}{l}0.99 \pm 0.03 \\
\quad(12)\end{array}$ & $\begin{array}{l}0.82 \pm 0.02 \\
\quad(12)\end{array}$ \\
\hline BCK 12.0 & $\begin{array}{c}0.107 \pm 0.007^{*} \\
(6)\end{array}$ & $\begin{array}{c}0.190 \pm 0.015^{*} \\
(6)\end{array}$ & $\begin{array}{l}0.93 \pm 0.02 \\
\quad(12)\end{array}$ & $\begin{array}{l}0.67 \pm 0.04 \\
(10)\end{array}$ \\
\hline BCK 4.5 & $\begin{array}{c}0.104 \pm 0.008^{*} \\
(6)\end{array}$ & $\begin{array}{c}0.180 \pm 0.031^{*} \\
(6)\end{array}$ & $\begin{array}{l}1.02 \pm 0.02 \\
\quad(12)\end{array}$ & $\begin{array}{c}0.90 \pm 0.02 \\
(9)\end{array}$ \\
\hline PHK 1.6 & $\begin{array}{c}0.098 \pm 0.012 \\
(6)\end{array}$ & $\begin{array}{c}0.162 \pm 0.022^{*} \\
(6)\end{array}$ & $\begin{array}{l}1.01 \pm 0.03 \\
\quad(12)\end{array}$ & $\begin{array}{l}0.92 \pm 0.02 \\
\quad(12)\end{array}$ \\
\hline Lab Tank & $\begin{array}{c}0.080 \pm 0.008 \\
(6)\end{array}$ & - & $\begin{array}{l}1.01 \pm 0.02 \\
\quad(12)\end{array}$ & $\begin{array}{c}0.76 \pm 0.02 \\
(7)\end{array}$ \\
\hline $\begin{array}{l}\text { Hinds Creek } \\
\text { (reference stream) }\end{array}$ & -- & $\begin{array}{c}0.071 \pm 0.006 \\
(12)\end{array}$ & $\begin{array}{c}1.02 \pm 0.01^{a} \\
(82)\end{array}$ & $\begin{array}{c}0.93 \pm 0.01^{b} \\
(70)\end{array}$ \\
\hline
\end{tabular}

Note: Values are mean \pm SE (sample size in parenthesis). Mercury values with asterisks $\left({ }^{*}\right)$ are significantly higher $(\propto=0.05)$ than the value for Hinds Creek dace. EFK - East Fork Poplar Creek kilometer, $\mathrm{MIK}=$ Mitchell Branch kilometer, $\mathrm{BCK}=$ Bear Creek kilometer, PHK $=$ Pinhook Branch kilometer.

${ }^{a}$ Mean condition factor of all dace collected in May 1992 from Hinds Creek.

${ }^{b}$ Mean condition factor of uncaged dace (i.e. resident fish) collected in August 1992 from Hinds Creek.

caged and resident fish was an expected consequence of limited food availability in the caged treatments, differences in the type of food ingested, and the short duration of exposure relative to time needed to attain steady state.

Evidence from both caged and resident reblacknose dace suggests that Mitchell Branch water and/or sediments are sources of mercury contamination to resident aquatic life, although the degree of mercury contamination in dace is low relative to that ordinarily found in fish from the upper reaches of East Fork Poplar Creek. Based on the results of the dace experiment, it appears likely that mercury levels in sunfish collected from Mitchell Branch are representative of the amount of mercury exposure at the collection site. 


\subsubsection{Mercury in Poplar Creek fish}

Mercury concentrations were measured in bluegill from several sites in Poplar Creek and the Clinch River to assess the relative importance of various streams (Bear Creek, EFPC, Mitchell Branch, and White Oak Creek) to the system. Results for the Poplar Creek area are shown in Table 4.1; results for the entire reservation in winter 1992/1993 are shown in Fig. 4.1.

Bluegill were collected from a site upstream of DOE impacts on Poplar Creek (PCK 18.2) in 1993 as a comparison to the level of mercury contamination in fish downstream. This reference site is further upstream than a site used previously (PCK 10.4) for this purpose, and should be far enough upstream to not be influenced by water level changes in Watts Barr Reservoir. Mercury concentrations in bluegill from this site were typical of fish from reference streams (Table 4.1), indicating that neither upstream sources of mercury in Poplar Creek nor movement of fish between sites were probable explanations for the high mercury levels at PCKs 8.2 and 6.9, located just upstream (PCK 8.2) and downstream (PCK 6.9) of Mitchell Branch.

The highest mean mercury concentrations in sunfish from Poplar Creek continues to be from PCKs 8.2 and 6.9 (Table 4.1). During the 1991-93 period, no fish from these sites exceeded the FDA action level of $1 \mu \mathrm{g} / \mathrm{g}$; however, a small number of fish (4/48) exceeded EPA's screening value of $0.6 \mu \mathrm{g} / \mathrm{g}$, and 19 of 48 fish collected from PCKs 8.2 and 6.9 exceeded the more conservative PGV of $0.42 \mu \mathrm{g} / \mathrm{g}$ (Travis et al. 1986; Table C.1). Mean mercury concentrations in fish from these two sites has changed little between 1987 and 1993; mean values were approximately 0.3 to $0.5 \mu \mathrm{g} / \mathrm{g}$ at both sites in most years. There was, again, very little difference in mean mercury concentrations between the two sites (less than $0.03 \mu \mathrm{g} / \mathrm{g}$ difference in each year from 1991 to 1993). No increase in mercury concentrations in fish in Poplar Creek could be attributed to inputs from Mitchell Branch.

The high mercury levels in fish from PCKs 8.2 and 6.9 are not readily explainable by a one-source-hypothesis, such as input from EFPC only. Levels of mercury in sunfish from EFPC decreased in proportion to dilution of Oak Ridge Y-12 Plant discharges at sites along the length of EFPC (Loar 1993), yet mercury levels in fish from PCKs 8.2 and 6.9 were similar to those found in lower EFPC, despite an almost four-fold dilution of EFPC upon entering Poplar Creek. One potential source of this mercury is Bear Creek. Mercury contamination is evident in fish from lower Bear Creek, but the extent of contamination in fish 

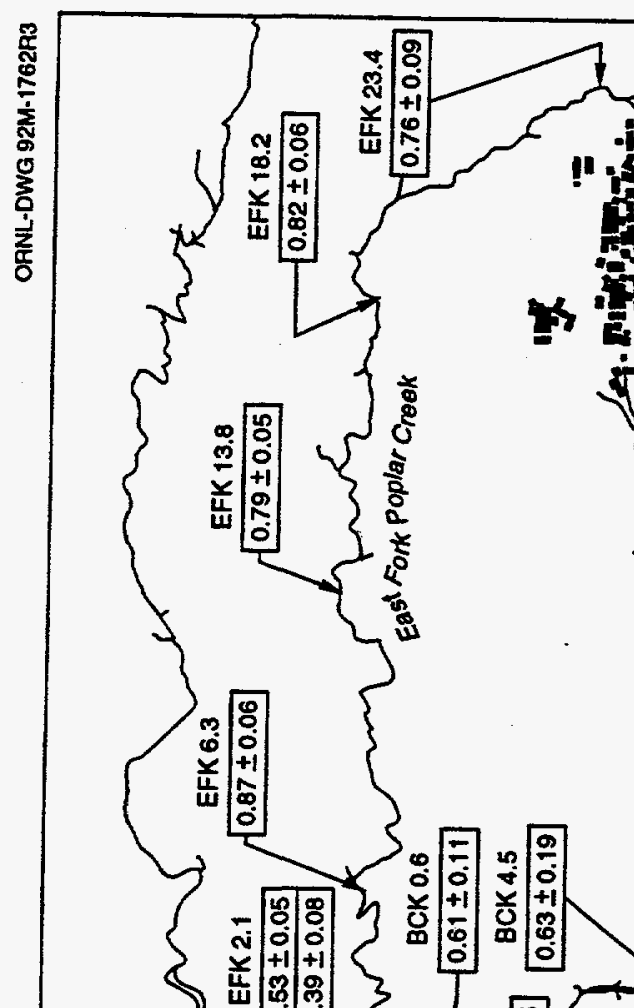

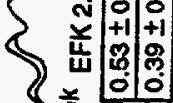
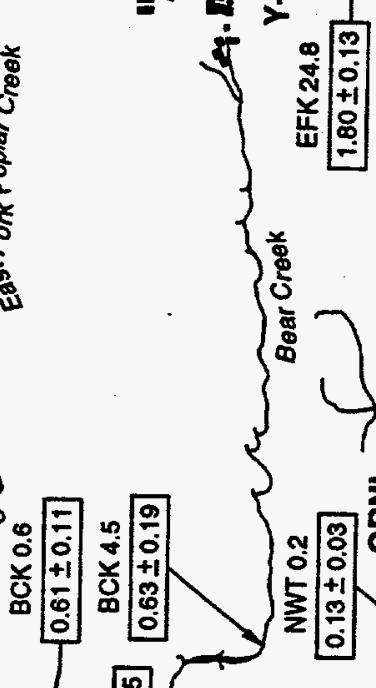

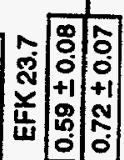
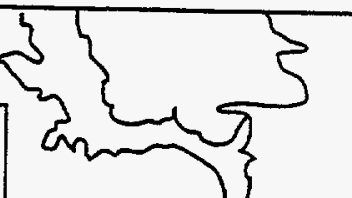

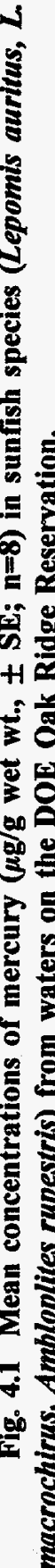


does not appear to be large enough to explain the high levels seen in Poplar Creek fish (Fig. 4.1). It is possible that either changes occur in the environmental chemistry of mercury in lower Poplar Creek, enhancing the biological availability of water-borne or sediment-associated mercury, or that additional sources of mercury (e.g., Poplar Creek sediments) occur in the reach of Poplar Creek near the Oak Ridge K-25 Site.

Mercury contamination in fish at the most downstream site on Poplar Creek (PCK 1.6) was lower than at PCKs 6.9 or 8.2. Low concentrations were also found in fish in the Clinch River (CRK 15.0) downstream of the mouth of Poplar Creek. Mercury concentrations in fish at CRK 15.0 were elevated over concentrations in fish at sites on the Clinch River upstream of the mouth of Poplar Creek (Fig. 4.1). Mercury concentrations in sunfish from the Clinch River upstream of the Poplar Creek mouth were typical of those found in fish from the uncontaminated reference stream, Hinds Creek, and other uncontaminated streams in east Tennessee (Southworth et al. 1994). Although mercury contamination from Oak Ridge operations within the Poplar Creek watershed is detectable in Clinch River fish downstream of the mouth of Poplar Creek, the degree of contamination, in comparison with human health threshold limits, appears to be minimal.

In 1992/1993, the level of mercury contamination in bluegill from Poplar Creek sites near the K-25 Site was generally $20-30 \%$ of the level in fish from the middle to upper reaches of EFPC, and about half the level in Bear Creek fish (Loar 1993; Fig. 4.1). The mean Hg concentrations in fish at these two sites were comparable to those from Mitchell Branch, lowermost EFPC (EFK 2.1), and the most mercury-contaminated site on White Oak Creek at kilometer (WCK) 2.9. Mean mercury concentrations in fish from lowermost Poplar Creek (PCK 1.6) were similar to those of fish from the other sites on White Oak Creek proper [WCK 3.5, WCK 2.3, White Oak Lake (WOL), and WCK 0.9]. The mean mercury concentration in bluegill from the Clinch River (CRK 15.0) was similar to fish concentrations in WOL, White Oak Creek Embayment (WCK 0.9), and in two locations on tributaries of White Oak Creek: Melton Branch kilometer (MEK) 0.2 and Northwest Tributary kilometer (NTK) 0.2 .

\subsubsection{Metals screening}

Despite abnormally high levels of some metals in Mitchell Branch water (Smith et al. 1993) and sediment (Ashwood et al. 1986), concentrations of metals (other than mercury) in 
Mitchell Branch fish in all three sampling years (1991-1993) were similar to those found in fish from the reference stream (Table 4.3; Table C.1). In 1991 and 1992, only selenium, thallium, and zinc were found above the analytical detection limit. The selenium and thallium detections were from only one fish, and at concentrations only slightly higher than the detection limit. Improved detection limits in the 1993 analyses allowed explicit comparison of concentrations of additional metals. Mean concentrations of chromium, copper, nickel, selenium, and zinc in Mitchell Branch sunfish were quite similar to those observed in Hinds Creek bluegill in 1993 by TVA at one of their reference sites (Melton Hill Reservoir) (TVA 1985,1986 ) and in fish in the National Contaminant Biomonitoring Program (Lowe et al. 1985).

Mean metal concentrations (other than mercury) in sunfish collected from sites in the vicinity of the K-25 Plant in 1993 were similar to those found in fish from Poplar Creek upstream of any DOE facilities (PCK 18.2) and to those in fish from Hinds Creek (HCK 12.7), the reference stream (Table 4.4). As with fish from Mitchell Branch, the concentrations of metals (Tables 4.3 and 4.4) in fish from near the K-25 Site were similar to other measures of local and national background concentrations (TVA 1985, 1986; Lowe et al. 1985). Mercury screening of fish from the three ponded tributaries of Poplar Creek (K-1007-P1, K-1007-P5, and K-710A) was conducted for the first time in spring 1993. Mercury concentrations in sunfish from the two $\mathrm{K}-1007$ ponds were very similar to concentrations in fish from reference sites (PCK 18.2 and HCK 12.7). Although the mean mercury concentration in fish from the $\mathrm{K}-710 \mathrm{~A}$ pond $(0.12 \mu \mathrm{g} / \mathrm{g})$ was about two times higher than found in fish from reference sites in the 1993 sampling year, past monitoring has shown that this level of mercury is within the range of reference site values (Ashwood et al. 1993, Southworth et al. in press).

A comparison of metal concentrations in fish from all K-25 sites with toxicological benchmarks or screening values indicates that fish from these sites pose little concern for use as human food (Tables 4.3, 4.4). The mean concentrations of all metals except arsenic and beryllium were at or below concentrations used by EPA and others to screen for levels of contamination that pose no threat for human consumption. EPA and PGV screening values for arsenic and beryllium are set below routine levels of detection due to the potential carcinogenity of these two contaminants; only arsenic was detected in these samples. Arsenic has a screening level lower than the concentration typical of fish from uncontaminated sites, 
Table 4.3. Mean ( \pm SE in parentheses) metal concentrations in redbreast sunfish (Lepomis auritus) from Mitchell Branch, 1991-1993

Reference and guidance values for these metals are given for comparison

\begin{tabular}{|c|c|c|c|c|c|c|c|c|}
\hline \multirow[b]{2}{*}{ Metal } & \multicolumn{3}{|c|}{ Mitchell Branch } & \multirow[b]{2}{*}{ Hinds Creek ${ }^{a}$} & \multirow[b]{2}{*}{$T_{V A}^{b}$} & \multirow[b]{2}{*}{ USFWS $^{c}$} & \multirow[b]{2}{*}{$\mathrm{PGV}^{d}$} & \multirow[b]{2}{*}{$\mathrm{EPA}^{e}$} \\
\hline & 1991 & 1992 & 1993 & & & & & \\
\hline Arsenic & $<0.05$ & $<0.05$ & $\begin{array}{c}0.05^{f} \\
(0.01)\end{array}$ & $<0.05$ & $<0.03$ & 0.16 & 0.0007 & 0.006 \\
\hline Beryllium & $<0.003$ & $<0.003$ & $<0.003$ & $<0.003$ & $<1$ & - & 0.004 & 0.0025 \\
\hline Cadmium & $<0.34$ & $<0.37$ & $<0.02$ & $<0.02$ & $\begin{array}{c}0.007 \\
(0.003)\end{array}$ & 0.04 & 1.0 & 10.8 \\
\hline Chromium & $<0.86$ & $<0.93$ & $\begin{array}{c}0.08^{g} \\
(0.02)\end{array}$ & $<0.05$ & 0.06 & - & 1.8 & 10,800 \\
\hline Copper & $<0.86$ & $<0.93$ & $\begin{array}{c}0.24 \\
(0.01)\end{array}$ & $\begin{array}{c}0.22 \\
(0.01)\end{array}$ & $\begin{array}{c}0.4 \\
(0.3)\end{array}$ & 0.86 & 36 & - \\
\hline Lead & $<0.86$ & $<0.93$ & $<0.02$ & $<0.02$ & $\begin{array}{c}0.21 \\
(0.33)\end{array}$ & 0.19 & 1.8 & - \\
\hline Mercury & $\begin{array}{c}0.32 \\
(0.05)\end{array}$ & $\begin{array}{c}0.25 \\
(0.03)\end{array}$ & $\begin{array}{c}0.33 \\
(0.03)\end{array}$ & $\begin{array}{c}0.06 \\
(0.01)\end{array}$ & $<0.1$ & 0.11 & 0.42 & 1.0 \\
\hline Nickel & $<0.86$ & $<0.93$ & $\begin{array}{c}0.06^{8} \\
(0.01)\end{array}$ & $<0.05$ & $<0.1$ & - & 5.2 & 2.15 \\
\hline Selenium & $\begin{array}{l}0.67^{f} \\
(0.08)\end{array}$ & $<0.93$ & $\begin{array}{c}0.41 \\
(0.05)\end{array}$ & $\begin{array}{c}0.25 \\
(0.01)\end{array}$ & $\begin{array}{l}0.7 \\
(0.2)\end{array}$ & 0.46 & 12 & 5.4 \\
\hline Silver & $<0.34$ & $<0.37$ & $<0.04$ & $<0.04$ & $<0.3$ & $\ldots$ & 0.29 & 2.48 \\
\hline Thallium & $0.02^{f}$ & $<0.02$ & $<0.02$ & $<0.02$ & $<1.0$ & - & 0.25 & 5.71 \\
\hline Uranium & $<0.02$ & $<0.003$ & $<0.003$ & $<0.003$ & - & - & - & - \\
\hline Zinc & $\begin{array}{c}5.8 \\
(0.22)\end{array}$ & $\begin{array}{l}5.7 \\
(0.19)\end{array}$ & $\begin{array}{c}5.2 \\
(0.2)\end{array}$ & $\begin{array}{l}5.8 \\
(0.07)\end{array}$ & $\begin{array}{l}8.4 \\
(2.6)\end{array}$ & 25.6 & 180 & - \\
\hline
\end{tabular}

Note: Values expressed as micrograms per pram, wet weight. The mean for nonmercurous metals is based on four individual fish except at HCK $12.7(n=3)$. For mercury, $n=8$ for Mitchell Branch in each year, $n=6$ for Hinds Creek. See Chapter 8 for full citations of references listed below.

aReference stream located in Anderson County, Tennessee.

${ }^{b}$ Mean concentrations of metals in fish collected by TVA from Melton Hill Reservoir ( $n=9$ for $\mathrm{As}, \mathrm{Cd}, \mathrm{Cr}, \mathrm{Ni}, \mathrm{Ag} ; n=2$ for others) TVA (1985). 1985).

Mean concentrations of metals in fish collected for the National Contaminant Biomonitoring Program (NCBP) (Lowe et al.

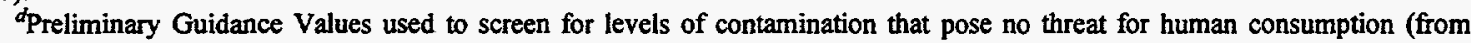
Hoffman et al. 1984; Travis et al. 1986).

'EPA fish tissue criteria in 1990 (EPA 1990).

One of four samples exceeded the detection limit.

${ }^{8}$ Three of four samples exceeded the detection limit. 
Table 4.4. Mean ( $\pm \mathrm{SE}$ in parentheses) metal concentrations in sunfish collected in the vicinity of the K-25 Site in spring 1993

Measurements expressed in micrograms per gram, wet weight

\begin{tabular}{|c|c|c|c|c|c|c|c|c|c|c|}
\hline \multirow[b]{3}{*}{ Metal } & \multicolumn{10}{|c|}{ Site } \\
\hline & \multicolumn{4}{|c|}{ Tributaries } & \multicolumn{4}{|c|}{ Poplar Creek } & \multirow{2}{*}{$\frac{\text { Clinch } \mathrm{R}^{a}}{\text { CRK15.0 }}$} & \multirow{2}{*}{$\frac{\text { Refer. Site }^{b}}{\text { HCK } 12.7}$} \\
\hline & K1007-P1 & K1007-P5 & K710A & MIK 0.2 & PCK 1.6 & PCK 6.9 & PCK 8.2 & PCK18.2 & & \\
\hline Arsenic & $\begin{array}{c}0.06^{c} \\
(0.01)\end{array}$ & $<0.05$ & $\begin{array}{c}0.06 \\
(0.01)\end{array}$ & $\begin{array}{c}0.05^{d} \\
(0.01)\end{array}$ & $\begin{array}{c}0.07^{*} \\
(0.01)\end{array}$ & .- & $\cdots$ & $<0.05$ & $\cdots$ & $<0.05$ \\
\hline Beryllium & $<0.003$ & $<0.003$ & $<0.003$ & $<0.003$ & $<0.003$ & - & -- & $<0.003$ & - & $<0.003$ \\
\hline Cadmium & $<0,02$ & $<0.02$ & $\begin{array}{l}0.02^{d} \\
(0.01)\end{array}$ & $<0.02$ & $<0.02$ & - &.- & $<0.02$ & -- & $<0.02$ \\
\hline Chromium & $<0.05$ & $\begin{array}{c}0.05^{d} \\
(0.01)\end{array}$ & $<0.05$ & $\begin{array}{c}0.08^{e} \\
(0.02)\end{array}$ & $<0.07$ & -- & -- & $<0.05$ & -- & $<0.05$ \\
\hline Copper & $\begin{array}{c}0.17 \\
(0.01)\end{array}$ & $\begin{array}{c}0.17 \\
(0.01)\end{array}$ & $\begin{array}{c}0.19 \\
(0.03)\end{array}$ & $\begin{array}{c}0.24 \\
(0.01)\end{array}$ & $\begin{array}{c}0.20 \\
(0.01)\end{array}$ & - & $\cdots$ & $\begin{array}{c}0.16 \\
(0.03)\end{array}$ & -- & $\begin{array}{c}0.22 \\
(0.01)\end{array}$ \\
\hline Lead & $<0.02$ & $<0.02$ & $<0.02$ & $<0.02$ & $<0.02$ & -- & -- & $<0.02$ &.- & $<0.02$ \\
\hline Mercury & $\begin{array}{c}0.09 \\
(0.01)\end{array}$ & $\begin{array}{c}0.05 \\
(0.01)\end{array}$ & $\begin{array}{c}0.12 \\
(0.01)\end{array}$ & $\begin{array}{c}0.33 \\
(0.03)\end{array}$ & $\begin{array}{c}0.25 \\
(0.05)\end{array}$ & $\begin{array}{c}0.36 \\
(0.03)\end{array}$ & $\begin{array}{c}0.34 \\
(0.05)\end{array}$ & $\begin{array}{c}0.06 \\
(0.01)\end{array}$ & $\begin{array}{c}0.18 \\
(0.03)\end{array}$ & $\begin{array}{c}0.06 \\
(0.01)\end{array}$ \\
\hline Nickel & $<0.05$ & $<0.05$ & $<0.05$ & $\begin{array}{c}0.06^{e} \\
(0.01)\end{array}$ & $\begin{array}{c}0.06^{d} \\
(0.01)\end{array}$ & -. & $\cdots$ & $<0.05$ & -- & $<0.05$ \\
\hline Selenium & $\begin{array}{c}0.35 \\
(0.01)\end{array}$ & $\begin{array}{c}0.30 \\
(0.03)\end{array}$ & $\begin{array}{c}0.54 \\
(0.04)\end{array}$ & $\begin{array}{c}0.41 \\
(0.05)\end{array}$ & $\begin{array}{c}0.45 \\
(0.03)\end{array}$ & - &.- & $\begin{array}{c}0.38 \\
(0.03)\end{array}$ & -- & $\begin{array}{c}0.25 \\
(0.01)\end{array}$ \\
\hline Silver & $<0.04$ & $<0.04$ & $<0.04$ & $<0.04$ & $<0.04$ & -- & -- & $<0.04$ & -- & $<0.04$ \\
\hline Thallium & $<0.02$ & $<0.02$ & $<0.02$ & $<0.02$ & $<0.02$ & -. & -- & $<0.02$ & -- & $<0.02$ \\
\hline Uranium & $<0.003$ & $<0.003$ & $<0.003$ & $<0.003$ & $<0.003$ & -. & - & $<0.003$ & -- & $<0.003$ \\
\hline Zinc & $\begin{array}{c}6.7 \\
(0.08)\end{array}$ & $\begin{array}{c}5.6 \\
(0.03)\end{array}$ & $\begin{array}{c}4.9 \\
(0.4)\end{array}$ & $\begin{array}{c}5.2 \\
(0.2)\end{array}$ & $\begin{array}{c}5.0 \\
(0.7)\end{array}$ & -- & -- & $\begin{array}{c}5.1 \\
(0.7)\end{array}$ & $\cdot$ & $\begin{array}{c}4.6 \\
(0.2)\end{array}$ \\
\hline
\end{tabular}

Note: Sunfish were bluegill (Lepomis macrochirus) at all sites except MIK 0.2 [redbreast sunfish (Lepomis auritus) were used at this site]. At each site where metals were analyzed, four individual fish comprise the mean, except at HCK $12.7(m=3)$. For mercury, eight individual fish were collected from each site except HCK $12.7(n=6)$.

MIK $=$ Mitchell Branch kilometer, PCK $=$ Poplar Creek kilometer, $\mathrm{CRK}=$ Clinch River kilometer and HCK $=$ Hinds Creek kilometer. Numbered designations refer to the kilometer distance above the stream mouth (e.g. site MIK 0.2 is on Mitchell Branch $0.2 \mathrm{~km}$ upstream of the mouth).

${ }^{a}$ Clinch River

${ }^{b}$ Reference Site

Two of four samples exceeded the detection limit. For samples reported below the detection limit, the detection limit value was used in calculating the mean.

${ }^{d}$ One of four samples exceeded the detection limit.

Three of four samples exceeded the detection limit. 
and also lower than the concentrations commonly found in other foodstuffs, such as fruits and vegetables (Bowen 1979).

\subsubsection{PCBs in Mitchell Branch fish}

Polychlorinated biphenyl concentrations were clearly elevated in fish from Mitchell Branch relative to fish from the reference stream, averaging at least an order of magnitude higher than the reference stream in each year from 1991 through 1993 (Table 4.5; Table C.2). A small number of individuals ( 3 of 40 redbreast sunfish) collected since 1989 contained PCB concentrations that exceeded the FDA tolerance level of $2.0 \mu \mathrm{g} / \mathrm{g}$ (FDA 1984a). The level of PCB contamination in Mitchell Branch fish is high for a relatively short-lived, low-lipid species such as redbreast sunfish; longer-lived older, fattier species such as channel catfish (Ictaurus punctatus), carp (Cyprinus carpio), or large-mouth bass (Micropterus salmoides), if present, would probably contain much higher levels. In general, the degree of PCB contamination in redbreast sunfish from Mitchell Branch was similar to the level of contamination found at the most highly contaminated sites on EFPC (EFKs 23.4, 23.7, 23.8) and Bear Creek (BCK 4.5) (Fig. 4.2).

Mean PCB concentrations in Mitchell Branch redbreast did not exhibit an increasing or decreasing trend over the 1989-1993 period. Average concentrations were highly variable temporally, ranging as low as $0.58 \mu \mathrm{g} / \mathrm{g}$ in 1991 to as high as $1.61 \mu \mathrm{g} / \mathrm{g}$ in 1989 . The significance of Mitchell Branch as a source of PCB contamination is evident when comparing the levels of contamination in fish collected in Poplar Creek upstream and downstream of the mouth of Mitchell Branch. Mean PCB concentrations in Mitchell Branch redbreast sunfish were typically an order of magnitude higher than mean PCB concentrations in bluegill at PCKs 6.9 and 8.2 in each year (Table 4.5), despite the close proximity of Poplar Creek sites to Mitchell Branch. These results suggest that Mitchell Branch is a substantial source of PCBs to its resident biota, and Mitchell Branch fish were not likely to have obtained such high PCB concentrations elsewhere.

\subsubsection{PCBs in Poplar Creek fish}

PCB concentrations were measured in bluegill from several sites in Poplar Creek to assess the relative importance of various inputs to the system. PCB results for the Poplar Creek area are shown in Table 4.5; results for the entire reservation are shown in 
Table 4.5. Polychlorinated biphenyl concentrations in redbreast sunfish (Lepomis auritus) and bluegill (L. macrochirus) collected from Mitchell Branch and Poplar Creek sites, 1987-1993

\begin{tabular}{|c|c|c|c|c|}
\hline Site $^{a}$ & Species & Date & $\begin{array}{c}\text { mean } \pm \mathrm{SE} \\
\text { (Arochlor- } 1254+ \\
1260, \mu \mathrm{g} / \mathrm{g} \text {, wet } \\
\text { wt.) }\end{array}$ & $\begin{array}{c}\text { Range } \\
\text { (Arochlor- } 1254+ \\
1260, \mu \mathrm{g} / \mathrm{g}, \text { wet } \\
\text { wt.) }\end{array}$ \\
\hline PCK 18.2 & Bluegill & Mar. 1993 & $0.08 \pm 0.02$ & $0.03-0.14$ \\
\hline PCK 10.4 & Bluegill & $\begin{array}{l}\text { Nov. } 1987 \\
\text { Nov. } 1988\end{array}$ & $\begin{array}{l}0.06 \pm 0.01 \\
0.05 \pm 0.03\end{array}$ & $\begin{array}{l}0.02-0.11 \\
0.01-0.26\end{array}$ \\
\hline PCK 8.2 & Bluegill & $\begin{array}{l}\text { Nov. } 1987 \\
\text { Nov. } 1988 \\
\text { Mar. } 1990 \\
\text { Feb. } 1991 \\
\text { Jul. } 1992 \\
\text { Mar. } 1993\end{array}$ & $\begin{array}{l}0.20 \pm 0.03 \\
0.31 \pm 0.07 \\
0.07 \pm 0.02 \\
0.05 \pm 0.02 \\
0.03 \pm 0.01 \\
0.03 \pm 0.01\end{array}$ & $\begin{array}{l}0.11-0.36 \\
0.08-0.59 \\
0.02-0.15 \\
0.01-0.10 \\
0.01-0.05 \\
0.01-0.05\end{array}$ \\
\hline MIK 0.2 & Redbreast & $\begin{array}{l}\text { Mar. } 1989 \\
\text { Jan. } 1990 \\
\text { Jan. } 1991 \\
\text { Jan. } 1992 \\
\text { Mar. } 1993\end{array}$ & $\begin{array}{l}1.61 \pm 0.32 \\
0.80 \pm 0.14 \\
0.58 \pm 0.15 \\
1.34 \pm 0.32 \\
0.76 \pm 0.15\end{array}$ & $\begin{array}{l}0.50-3.27 \\
0.23-1.55 \\
0.03-1.28 \\
0.40-3.05 \\
0.10-1.36\end{array}$ \\
\hline PCK 6.9 & Bluegill & $\begin{array}{l}\text { Jun. } 1987 \\
\text { Nov. } 1987 \\
\text { Nov. } 1988 \\
\text { Mar. } 1990 \\
\text { Feb. } 1991 \\
\text { Jul. } 1992 \\
\text { Mar. } 1993\end{array}$ & $\begin{array}{l}0.22 \pm 0.06 \\
0.26 \pm 0.04 \\
0.21 \pm 0.05 \\
0.12 \pm 0.01 \\
0.05 \pm 0.02 \\
0.03 \pm 0.01 \\
0.17 \pm 0.09\end{array}$ & $\begin{array}{l}0.05-0.53 \\
0.14-0.47 \\
0.08-0.40 \\
0.07-0.23 \\
0.01-0.10 \\
0.01-0.07 \\
0.03-0.81\end{array}$ \\
\hline PCK 1.6 & Bluegill & $\begin{array}{l}\text { Dec. } 1987 \\
\text { Nov. } 1988 \\
\text { Mar. } 1993\end{array}$ & $\begin{array}{c}0.17 \pm 0.03 \\
0.19 \pm 0.04 \\
0.11 \pm 0.02\end{array}$ & $\begin{array}{l}0.10-0.37 \\
0.06-0.39 \\
0.02-0.22\end{array}$ \\
\hline
\end{tabular}

Note: $n=8$ fish per site per year. The mean polychlorinated biphenyl (PCB) concentration in reference stream (Hinds Creek) sunfish, 1991-1992, was $0.03 \pm 0.01(n=40)$. In 1993, the mean PCB concentration in Hinds Creek sunfish was higher, averaging $0.11 \pm 0.04(n=4)$.

${ }^{a} \mathrm{PCK}=$ Poplar Creek kilometer, MIK = Mitchell Branch kilometer. 


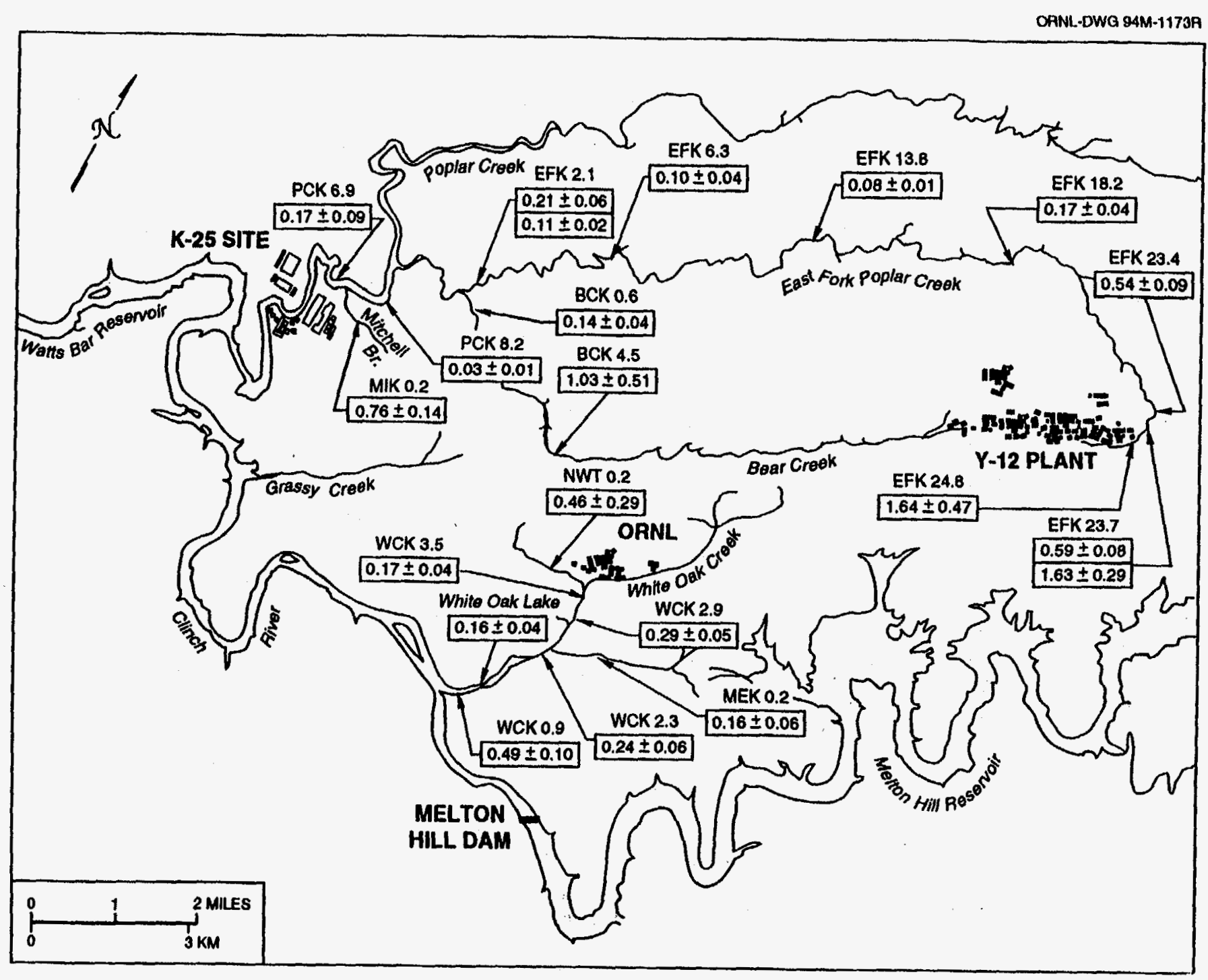
macrochirus, Ambloplites rupestris) from waters on the Department of Energy Oak Ridge Reservation. MIK = Mitchell Branch kilometer, PCK = Poplar Creek kilometer, EFK = East Fork Poplar Creek kilometer, BCK $=$ Bear Creek kilometer, WCK $=$ White Oak Creek kilometer, MEK $=$ Melton Branch kilometer, NWT $=$ Northwest Tributary, ORNL $=$ Oak Ridge National Laboratory. 
During the 1991-1992 period, PCB concentrations were near background in bluegill from PCK 6.9 and PCK 8.2 (Table 4.5). Prior to this period, PCB concentrations in Poplar Creek did not decline proportionally to the dilution of EFPC in Poplar Creek, but rather remained at levels typical of or higher than those of lower EFPC (Southworth 1990). Dilution or migration appeared to be more of a factor in 1991 and 1992, when PCB levels were substantially lower in Poplar Creek fish than in fish from the major PCB-contaminated tributaries to Poplar Creek (Mitchell Branch, Bear Creek, and EFPC).

In 1993, two additional sites on Poplar Creek were sampled, PCK 18.2 (upstream of all DOE impacts), and PCK 1.6 (downstream of all major K-25 Site discharges, including the 1007 ponds-see next section). The mean PCB concentration in PCK 18.2 fish was similar to reference stream concentrations reported in 1993 , although this level $(0.08 \mu \mathrm{g} / \mathrm{g})$ is slightly higher than typically observed in reference fish in past years $(0.03 \mu \mathrm{g} / \mathrm{g}$; Table 4.5$)$. Only the mean concentration in fish from PCK 6.9 (downstream of Mitchell Branch) was substantially higher than the PCK 18.2 reference site. Average PCB concentrations in fish at the two sites downstream of major K-25 Site inputs (PCKs 6.9 and 1.6) were higher (0.17 and 0.11 at PCK 6.9 and PCK 1.6 respectively) than upstream of the K-25 Site (PCK 8.2); however, the mean PCB concentration in 1993 at PCK 8.2 was anomalously low $(0.03 \mu \mathrm{g} / \mathrm{g})$. As has been the case previously (Smith et al. 1994), no relationship was obvious between PCB concentrations in fish in Poplar Creek and proximity to PCB-contaminated tributaries such as Mitchell Branch and K-1007 ponds outfall. Overall, the effect of the PCB-contaminated inputs from the K-25 Site to Poplar Creek appears to be undetectable in Poplar Creek sunfish.

In 1992-1993, the degree of PCB contamination in bluegill from the Poplar Creek sites near the Oak Ridge K-25 Site (PCKs 8.2, 6.9, and 1.6) was relatively low compared with other sites on the reservation (Fig. 4.2). The level of PCB contamination in Poplar Creek bluegill was most similar to levels in fish from lowermost EFPC, in rockbass from lower Bear Creek, and in fish from sites in the White Oak Creek drainage (MEK 0.2, WCK 3.5, and WOL).

Channel catfish have been collected annually since 1988 at PCK 6.9 and CRK 15.0 as part of an evaluation of the importance of inputs from DOE sources in contributing to PCB contamination in Watts Bar Reservoir. Results of this study are given in detail in Ashwood et al. 1994 and are only summarized here. In 1991 and 1992, PCB concentrations in catfish were, on average, higher at CRK 15.0 than in Poplar Creek-a change from previous 
years and in 1993 (Table 4.6). Mean PCB concentrations in catfish at sites in Poplar Creek (PCK 6.9), the Clinch River near ORNL (CRK 32.2), and the K-25 Site (CRK 15.0) and did not differ significantly ( $p>0.05$, ANOVA) in 1993. The results are consistent with the pattern seen in previous years. It is likely that movements of channel catfish and forage fish act to spread PCB contamination away from point sources; this results in a rather uniform distribution of PCB contamination in catfish throughout Watts Bar Reservoir. The mean PCB concentrations in channel catfish continue to justify the precautionary fish consumption advisory issued by the TDEC.

\subsubsection{PCB Screening in pond fish}

PCB screening of largemouth bass (Micropterus salmoides) was conducted in March and April 1993 from three ponded tributaries of Poplar Creek (K-1007-P1, K-1007-P5, and K-710A ponds; Fig. 2.1). Largemouth bass were chosen for PCB screening because they likely represent the worst-case level of PCB contamination in fish from the ponds. The mean PCB concentration (Arochlor $1254+1260$ ) of four individually analyzed bass from the $\mathrm{K}-1007-\mathrm{P} 1$ pond was $16.1 \pm 9.0 \mu \mathrm{g} / \mathrm{g}$, wet wt (mean $\pm \mathrm{SE}$ ) (Table 4.7). The high variability about the mean was due in large part to one very highly contaminated fish ( $42.9 \mu \mathrm{g} / \mathrm{g})$. An independent reanalysis of archived muscle tissue from the same fish by Southwest Research Institute in San Antonio, Texas, confirmed the presence of high PCB concentrations. The mean $\mathrm{PCB}$ concentration for K-1007-P1 bass upon reanalysis (which included detectable concentrations of Arochlor-1248 as well as Arochlor-1254 and 1260) was $33.7 \pm 5.6$ SE. The mean PCB concentration in K-1007-P1 largemouth bass was higher than previously found in fish from the most PCB-contaminated sites on the ORR and is substantially higher than the FDA $2-\mu \mathrm{g} / \mathrm{g}$ tolerance level for PCBs of (FDA 1984a).

PCB concentrations in fish from the K-1007-P5 pond (located upstream of the P1 pond) were far lower (Table 4.7), suggesting that the source(s) to the $\mathrm{P} 1$ pond is not from the P5 vicinity. The mean $\mathrm{PCB}$ concentration of $0.03 \pm 0.01 \mu \mathrm{g} / \mathrm{g}$ in four bluegill (Lepomis macrochirus) from the P5 pond was near background levels, and PCB concentrations in the two largemouth bass collected from the P5 pond were $0.13 \mu \mathrm{g} / \mathrm{g}$ and $1.21 \mu \mathrm{g} / \mathrm{g}$. The mean $\mathrm{PCB}$ concentration in four largemouth bass from the $\mathrm{K}-710 \mathrm{~A}$ pond was $0.36 \pm 0.13 \mu \mathrm{g} / \mathrm{g}$. The culvert at the downstream end of $\mathrm{K}-710 \mathrm{~A}$ pond does not appear to be an effective barrier to water and/or fish exchanges, since water levels in the pond change with water level changes in 
Table 4.6. Average concentrations of polychlorinated biphenyls and fraction of fish exceeding

the FDA limit, for channel catfish from White Oak Creek embayment, the Clinch River, lower Poplar Creek (PCK), and Melton Hill Reservoir, 1986-1993

Measured in micrograms per gram, wet weight

\begin{tabular}{|c|c|c|c|c|c|c|c|c|c|c|c|c|c|c|c|c|}
\hline \multirow[b]{2}{*}{ Site } & \multicolumn{8}{|c|}{ PCBs } & \multicolumn{8}{|c|}{ Fraction over FDA limit } \\
\hline & 1986 & 1987 & 1988 & 1989 & 1990 & 1991 & 1992 & 1993 & 1986 & 1987 & 1988 & 1989 & 1990 & 1991 & 1992 & 1993 \\
\hline WCK 0.3 & 1.30 & 1.59 & 0.96 & 1.54 & 3.56 & 3.60 & 3.29 & 8.40 & $3 / 12$ & $2 / 8$ & $2 / 8$ & $4 / 8$ & $4 / 8$ & $6 / 8$ & $5 / 8$ & $4 / 4$ \\
\hline CRK 32.2 & 1.01 & 1.61 & 0.58 & 1.20 & 0.31 & 1.38 & 0.36 & 0.67 & $0 / 8$ & $2 / 8$ & $1 / 8$ & $1 / 8$ & $0 / 8$ & $1 / 8$ & $0 / 8$ & $0 / 8$ \\
\hline MHR & 0.46 & 0.81 & 0.52 & 0.28 & 0.41 & 0.29 & 0.34 & 0.62 & $0 / 6$ & $1 / 7$ & $0 / 10$ & $0 / 8$ & $0 / 8$ & $0 / 8$ & $0 / 8$ & $0 / 8$ \\
\hline PCK 6.9 & NS & NS & 0.71 & 1.07 & 0.92 & 0.68 & 0.54 & 0.92 & NS & NS & $0 / 8$ & $1 / 8$ & $1 / 8$ & $0 / 8$ & $0 / 8$ & $0 / 8$ \\
\hline CRK 15.0 & NS & NS & 0.50 & 0.79 & 0.88 & 1.08 & 1.27 & 0.63 & NS & NS & $0 / 9$ & $1 / 8$ & $1 / 8$ & $1 / 8$ & $2 / 8$ & $0 / 8$ \\
\hline
\end{tabular}

Note: $\mathrm{NS}=$ not sampled. WOK $=$ White Oak Creek kilometer, CRK $=$ Clinch River kilometer, $\mathrm{MHR}=$ Melton Hill Reservoir, PCK $=$ Poplar Creek kilometer. 
Table 4.7. Polychlorinated biphenyl concentrations $(\mu \mathrm{g} / \mathrm{g}$, wet wt.) in fish from ponds near the K-25 Site in spring 1993

\begin{tabular}{lcccc}
\hline & & & \multicolumn{2}{c}{ FDA $^{a}$ exceedences } \\
Site & Species & Mean \pm S.E. & Range & $0 / 4$ \\
K-1007-P5 & $\begin{array}{c}\text { Bluegill } \\
\text { Largemouth bass }\end{array}$ & $0.03 \pm 0.01$ & $0.01-0.04$ & $0 / 2$ \\
& $0.67 \pm 0.54$ & $0.13-1.21$ & \\
K-1007-P1 & & & $4 / 4$ \\
(Independent Reanalysis) & & & $4 / 4$ \\
& & $16.1 \pm 9.0$ & $20.5-47.8$ & \\
K-710A & $33.7 \pm 5.6$ & & $0 / 4$ \\
\hline
\end{tabular}

Number of samples exceeding the Food and Drug Administration threshold limit for polychlorinated biphenyls of $2.0 \mu \mathrm{g} / \mathrm{g}$ divided by the total number of samples $(n)$.

Poplar Creek. Bass movement into the pond from the PCB-contaminated Poplar Creek seems likely.

The 1993 results of PCB tracking studies using bluegill in Poplar Creek suggest that the K-1007-P1 outfall to Poplar Creek is no greater a contributor of PCBs to fish in Poplar Creek than any of the upstream DOE inputs (see previous section). The mean PCB concentration in bluegill collected downstream of the K-1007-P1 discharge to Poplar Creek (PCK 1.6) was no higher than the mean PCB concentration in bluegill upstream of the discharge (PCK 6.9) (Table 4.5). Similar results were evident in bluegill collected in 1987 and 1988 (Table 4.5). Interpretation of such patterns is complicated by the unusual hydrodynamics of lower Poplar Creek (upstream hydroelectric generation causes daily flow reversals and flushing with Clinch River water) and the similarity of the lower creek to a reservoir, rather than a stream, habitat. If sunfish in lower Poplar Creek range more widely than typical stream sunfish, that, in combination with the complex hydrodynamic mixing, may tend to make the PCB contamination pattern in sunfish relatively homogeneous throughout the embayment, obfuscating any relationship to specific point sources.

\subsubsection{Organics in caged clams}

Caged clams held in Mitchell Branch for 4 weeks accumulated substantial concentrations of PCBs in all exposure periods from 1991 to 1993 (Table 4.8). Mean concentrations ranged from $1.4 \mu \mathrm{g} / \mathrm{g}$ in 1991 to $0.35 \mu \mathrm{g} / \mathrm{g}$ in 1993. Previous clam exposures in Mitchell Branch also resulted in substantial PCB accumulation (Smith et al. 1993, 1994). The degree of PCB 
accumulation noted in clams was consistent with the high concentrations of PCBs found in redbreast sunfish over this period (Table 4.5).

PCB concentrations in clams decreased over the 3-year period; however, a similar decrease was not apparent in sunfish (Tables 4.5 and 4.8). PCB concentrations in sunfish represent a time integrated exposure of several months to more than a year, while the introduced clams only monitor a 1-month period. Concentrations in fish thus provide a more reliable indicator of temporal trends. The data collected to date show that Mitchell Branch contains significant PCB contamination, that is not rapidly increasing or decreasing.

Screening for organic contamination in clams placed at two pond sites (K-1007-P1 and K710A) and at lower Poplar Creek (PCK 1.6) detected elevated concentrations of PCBs. The high PCB concentrations in clams at K-1007-P1 $(0.49 \mu \mathrm{g} / \mathrm{g})$ corroborates the conclusions based on data from bass at this site. The average PCB concentration in clams from $\mathrm{K}-710 \mathrm{~A}$ $(0.26 \mu \mathrm{g} / \mathrm{g})$ indicates that the pond is PCB contaminated; however, the free exchange of Poplar Creek water that occurs with water level changes in Watts Bar reservoir makes decoupling the two systems difficult. PCB contamination in the pond may be due to retention and resuspension of Poplar Creek sediment. The mean PCB concentration in four very large bass from $710 \mathrm{~A}$ (a relatively low $0.36 \mu \mathrm{g} / \mathrm{g}$ ) likely represents the maximum level of PCBs in fish from this system, and further monitoring of PCBs in this pond does not appear to be warranted. A slightly elevated average concentration of PCBs $(0.09 \mu \mathrm{g} / \mathrm{g})$ was found in clams placed at PCK 1.6 in comparison to the concentration in clams placed upstream of DOE discharges (PCK 18.2). This was consistent with fish data that indicated the presence of PCB contamination in Poplar Creek downstream from the mouth of EFPC.

Although the accumulation of PCBs by caged clams can be influenced by the presence of toxicants such as residual chlorine and by the abundance of particulate food in the water, the concentrations in clams can be viewed as providing an index of the concentration of waterborne PCBs (which is generally below the detection limit of analytical procedures routinely used to monitor PCBs in water at the DOE Oak Ridge facilities). A rough comparison of the mass flux of PCBs from Mitchell Branch and the K-1007-P1 discharges to the mass flux from upper EFPC can be made by comparing the products of PCB concentrations in clams times average flow at the site. Although only data from upper EFPC is available, the mass flux of PCBs in lower EFPC (with much greater flow) would be expected to be even greater than upper EFPC (despite expected lower PCB concentrations in 
Table 4.8. Mean concentrations of organic compounds detected in duplicate samples of caged clams (Corbicula fluminea) at sites near the K-25 Site, 1991-1993

Measurements in micrograms per gram, wet weight

\begin{tabular}{|c|c|c|c|c|c|c|c|}
\hline \multirow[b]{2}{*}{ Sites by year } & \multicolumn{7}{|c|}{ Analytes $^{a}$} \\
\hline & $\begin{array}{l}\text { Total } \\
\text { PCBs }\end{array}$ & DDT & $\begin{array}{c}\text { Total } \\
\text { chlordane }\end{array}$ & aldrin & $\begin{array}{l}\text { Benzoic } \\
\text { acid }\end{array}$ & $\begin{array}{l}\text { Di-n-octyl } \\
\text { phthalate }\end{array}$ & $\begin{array}{c}\text { Bis(2-ethylhexyl) } \\
\text { phthalate }\end{array}$ \\
\hline \multicolumn{8}{|l|}{1991} \\
\hline MIK $0.2^{b}$ & 1.4 & 0.1 & 0.01 & 0.01 & - & - & - \\
\hline \multicolumn{8}{|l|}{1992} \\
\hline MIK 0.2 & 0.52 & 0.05 & - & 0.02 & $4.8^{c}$ & - & - \\
\hline \multicolumn{8}{|l|}{1993} \\
\hline MIK 0.2 & 0.35 & - & 0.006 & - & - & - & $20.4^{d}$ \\
\hline $\mathrm{K}-1007-\mathrm{P} 1$ & 0.49 & - & - & - & - & - & - \\
\hline $\mathrm{K}-710 \mathrm{~A}$ & 0.26 & - & 0.004 & - & - & $2.0^{d}$ & - \\
\hline PCK 1.6 & 0.09 & - & 0.003 & - & - & - & - \\
\hline PCK 18.2 & $<0.04$ & - & 0.002 & - & - & - & $5.4^{d}$ \\
\hline
\end{tabular}

Note: Organic compounds not noted were below detection limits (see Appendix). DDT - dichlorodiphenyltrichloroethane; $\mathrm{PCB}=$ polychlorinated biphenyls; $\mathrm{MKK}=$ Mitchell Branch kilometer; $\mathrm{PCK}=$ Poplar Creek kilometer.

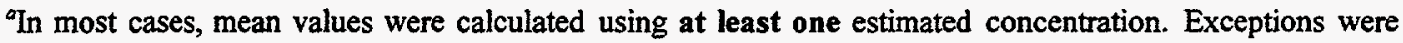
values cited at MK 0.2 in 1991 and the two bis(2-ethylhexyl) phthalate detections. Estimated concentrations were reported by the analytical laboratory when compounds were detected, but below the range of reliable quantitation. $\mathrm{n}=2$ clam composite samples for each site in each year unless otherwise noted.

${ }^{b}$ Only one clam composite sample was analyzed in 1991 at this site.

Benzoic acid was detected in reference samples with this submission. Benzoic acid concentrations are likely to be an artifact of the analytical procedures.

${ }^{d}$ Compound was not detected in one of two duplicate samples. The detection limit value was used to calculate the mean. 
clams downstream). A mass flux comparison yields values of $0.29(0.49 \mu \mathrm{g} / \mathrm{g} \times 26 \mathrm{~L} / \mathrm{s})$ for $\mathrm{K}-1007-\mathrm{P} 1,0.36(0.35 \mu \mathrm{g} / \mathrm{g} \times 46 \mathrm{~L} / \mathrm{s})$ for Mitchell Branch, and $3.45(0.69 \mu \mathrm{g} / \mathrm{g} \times 219 \mathrm{~L} / \mathrm{s})$ for EFPC at the Y-12 Plant. PCB inputs to Poplar Creek from Mitchell Branch and the K-1007-P1 ponds, while not inconsequential, appear to be a small percentage of the total inputs from sources upstream from the K-25 Site.

Very low concentrations of other organic compounds were detected in clams placed in Poplar Creek and associated tributaries near the K-25 Site (Table C.3). With the exception of the K-1007-P1 site, chlordane was detected at all sites, including the reference site, but at concentrations far below EPA screening levels (EPA 1990) and near the limit of routine analytical detection. Two other pesticides, dichlorodiphenyl-trichloroethane (DDT) and aldrin, were also detected at levels near the detection limit in Mitchell Branch in 1991 and 1992 (Table 4.8). Aldrin was detected previously in Mitchell Branch (Smith et al. 1994). Benzoic acid, a common artifact of the analytical procedures, was detected in Mitchell Branch and in reference samples.

Two phthalate compounds were detected in clams from Mitchell Branch and the K-710A pond, but the detections should be considered non-confirmatory. $\mathrm{Di}-N$-octyl phthalate was reported below the range of reliable quantitation in one of two clam samples from K-710A. Bis (2-ethylhexyl) phthalate was detected in one of two duplicate clam samples from Mitchell Branch, and in one of two duplicate samples from a reference site (PCK 18.2). Phthalates have been detected in clam samples previously placed in Mitchell Branch (Smith et al. 1993); however, these data must be regarded with caution since phthalates are common laboratory and sample contaminants.

\subsubsection{Conclusions}

Mercury and PCBs are the only contaminants that accumulate to above background levels in fish and clams at sites near the K-25 Site. Mercury bioaccumulation was observed in fish in-Mitchell Branch and nearby sites on Poplar Creek. Mercury concentrations did not exceed the FDA limit, but some fish did exceed more conservative screening thresholds (EPA 1993). Evidence from the caged and resident blacknose dace experiment suggests that the mercury contamination in Mitchell Branch fish arises from a source within that watershed, rather than being a consequence of contaminated fish immigrating from nearby Poplar Creek. Based on the results of the blacknose dace experiment, it appears likely that the sunfish collected from 
Mitchell Branch are representative of the degree of contaminant exposure at the collection site.

PCB concentrations were high in fish from two localized aquatic habitats at the K-25 Site (Mitchell Branch, K-1007-P1), but were much lower in fish from Poplar Creek in the vicinity of discharges from these sites. Some fish in Mitchell Branch contained PCB concentrations in excess of the 2- $\mu \mathrm{g} / \mathrm{g}$ FDA action level. PCB screening of largemouth bass in the ponded tributaries at the K-25 Site revealed significant contamination in fish from the K-1007-P1 pond. Mitchell Branch and K-1007-P1 undoubtedly are sources of PCB contamination to Poplar Creek, but their significance as a source of PCB contamination to the biota in Poplar Creek and the Clinch River relative to other known sources (EFPC, White Oak Creek, Bear Creek, and Poplar Creek sediment) cannot be ascertained from a comparison of concentrations of PCBs in different species of fish from different habitats. Channel catfish from Poplar Creek continue to contain PCB concentrations similar to other sites in the Clinch River/Watts Bar system. PCB concentrations in caged clams that sample waterborne PCBs for a fixed time interval can be used to infer relative fluxes of PCBs from specific sources. Results of such a comparison indicate that chronic PCB fluxes to Poplar Creek from known K-25 Site sources are significant but are probably a small percentage of the total input from sources upstream from the K-25 Site.

Metals screening of fish from lower Poplar Creek, Mitchell Branch, and the pond sites revealed little evidence of contamination. Concentrations were either below detection limits or not substantially higher than reference values. Screening for organics in caged clams detected PCBs at high concentrations in Mitchell Branch and the K-1007-P1 pond consistent with the results of PCB monitoring in fish at those sites. Other organic compounds were detected at very low concentrations; most values were estimated concentrations below the quantification limit of the analytical method. An exception is the very high concentration of bis(2ethylhexyl) phthalate detected in clams from Mitchell Branch. These data should be viewed with skepticism, however, since the compound was detected in only one of the two duplicates and was also detected at a substantial concentration in one reference site (PCK 18.2) sample but not its duplicate. 


\subsubsection{Future Studies}

The most significant contaminant bioaccumulation problems near the $\mathrm{K}-25$ Site are the high concentration of PCBs in fish in Mitchell Branch and K-1007-P1 and the possible export of PCBs from these two systems to Poplar Creek and Watts Bar Reservoir. A key objective of future studies will be to identify and characterize the PCB source(s) in Mitchell Branch and the K-1007 pond series. The results of the screening study in 1993 indicate that fish contaminant concentrations in the K-1007 pond approach or exceed commonly cited human health threshold limits; thus, monitoring will be initiated to more thoroughly track spatial and temporal changes in those contaminant levels. Caged clams will again be used to estimate the importance of Mitchell Branch and K-1007 inputs of PCBs to Poplar Creek relative to other sources.

In 1994, a survey of PCB contamination in fish in the remaining unsampled ponds in the $\mathrm{K}-1007$ series will be initiated. In addition to routine sampling of sunfish in Mitchell Branch, caged clams may be tried in upper Mitchell Branch (upstream and downstream of SDs 170, 180 , and 190) in an attempt to evaluate possible PCB source(s) in that system. Staff in the K-25 BMAP bioaccumulation task will continue to work closely with Y-12 BMAP staff in the development and application of passive monitors of PCB contamination in aquatic systems, which may eventually prove valuable in locating PCB sources within the K-25 Site storm sewer network.

Routine tracking of mercury and PCB contamination using sunfish will continue at sites on Poplar Creek to evaluate the changes over time in inputs of those contaminants to that system. Metals screening of fish from lower Poplar Creek, Mitchell Branch, and the pond sites revealed no evidence of contamination and no concerns with respect to human consumption of fish. Metals other than mercury will not be analyzed in fish filets in 1994. Whole body or specific tissue (liver, kidney) analyses for metals in fish may be needed in the future to address specific ecotoxicological questions at specific sites. Such future studies will be planned in response to a demonstrated need for such data.

Screening for organics in caged clams detected a very high concentration of bis (2-ethylhexyl) phthalate in Mitchell Branch, as well as low concentrations of aldrin over a 3-year period. Routine monitoring of organics will continue at this site. Only trace concentrations (below method quantitation limits) of a few organic compounds were detected 
at the other sites monitored in the screening study; future monitoring, therefore, is not warranted.

\subsection{CONTAMINANT ACCUMULATION IN TERRESTRIAL BIOTA}

Biological monitoring programs typically focus on aquatic organisms because these organisms are directly exposed to waterborne contaminants. However, many terrestrial species obtain a substantial portion of their diet from aquatic sources; and some terrestrial species, especially waterfowl, spend a significant portion of their lifetime in the water.

Of contaminants that bioaccumulate and are concentrated as they pass up the foodchain, terrestrial predators, especially piscivorous animals, may receive a higher dose than would be predicted solely by measuring bioaccumulation in the aquatic system. Previous K-25 BMAP data indicate that two contaminants with a high bioaccumulation potential-mercury and PCBs-are found at elevated levels in Mitchell Branch and Poplar Creek. Thus, sensitive terrestrial organisms may be receiving a significant dose of these contaminants from K-25 Site sources.

In order to assess the potential magnitude of exposure within the terrestrial ecosystem, this task evaluated two terrestrial species known to bioaccumulate contaminants from the aquatic system. Three subtasks, two of which are extensions of reservation-wide monitoring efforts, were begun as 1-year trials to determine whether sufficient exposure exists to warrant further study.

\subsubsection{Waterfowl Monitoring (B. G. Blaylock, B. R. O'Neal and D. K. Cox)}

\subsubsection{Introduction}

Streams and ponds located on the ORR are used as resting areas for migrant waterfowl and as nesting sites for resident populations. Waterfowl using waste disposal ponds can accumulate contaminants by ingesting food or water. The accumulation of contaminants is greatly influenced by the feeding habits of the different species of waterfowl. Because of the mobility of waterfowl, they can be direct vectors of contaminants from aquatic systems on the ORR to humans off-site when they are harvested by hunters for food. As part of the ORNL BMAP, a study was initiated in 1987 to assess the waterfowl uptake of radionuclides and other contaminants from White Oak Lake and other waste disposal areas at ORNL. 
The study was extended to include sites near the K-25 Site in late 1987. Because the resident Canada goose population has become well established on the ORR and geese have been found nesting at waste disposal ponds, the study was extended to monitor the local population and use these data to estimate the probability of a hunter harvesting a bird that had resided on the ORR. An annual leg-banding study, initiated in 1988, included placing throat collars with visible identification numbers on geese during the molting season. A census of the population is conducted on a weekly basis to estimate the population size and monitor the movement of individual geese.

\subsubsection{Methods}

\section{Waterfowl census and Canada goose banding}

Thirteen sites, including some inside the security area, are monitored on a weekly basis at the K-25 Site. During June 1993, in cooperation with the Tennessee Wildlife Resources Agency and the University of Tennessee Wildlife Society, adult and juvenile geese were rounded up to be fitted with leg bands. Adult geese were fitted with leg bands and white throat collars displaying black identification codes, and young birds (juveniles) were fitted with leg bands only. Codes on the throat collars are recorded each week during the waterfowl census to track the movement of individual geese.

\section{Contaminants in Canada Geese}

Waterfowl are collected periodically on the ORR for radiological and nonradiological analyses. In August 1993, fish collected from pond K-1007B at the K-25 Site were found to have high concentrations of PCBs. Concerns arose that Canada geese, which have been known to frequent the pond, may also have high concentrations of PCBs.

Five Canada geese, which had been banded and collared in 1989-1993 were collected near the K-1007B pond. Data from the waterfowl study showed that these geese had been observed at the K-25 Site for 1 to 5 years; although they were also observed at other areas. For example, one goose (C19T), which was collared in 1989 at the K-25 Site, was observed 41 times at the K-25 Site, 2 times at the Y-12 Plant, 1 time at the Oak Ridge Marina, and 1 time at the ORNL Swan Pond. The waterfowl data confirmed that these were resident geese. Five Canada geese were also collected below Norris dam. Breast and liver tissue were analyzed for PCBs. Breast, liver, and bone samples were analyzed for gamma-emitting 
radionuclides $\left({ }^{60} \mathrm{Co},{ }^{137} \mathrm{Cs}\right.$, etc. $)$. Selected samples will be analyzed for ${ }^{99} \mathrm{Tc},{ }^{239} \mathrm{Pu},{ }^{240} \mathrm{Pu},{ }^{90} \mathrm{Sr}$, ${ }^{235} \mathrm{U}$, and ${ }^{238} \mathrm{U}$. Breast and liver will also be analyzed for cadmium, chromium, mercury, lead, and selenium.

\subsubsection{Results and Discussion}

\section{Waterfowl census and Canada goose banding}

The total number of Canada geese sighted at the K-25 Site from June 1993 to March 1994 is depicted in Fig. 4.3. For comparative purposes, the data for June 1992 to March 1993 are also given in Fig. 4.3. The population trends are generally the same, except during October-January 1993-1994, when an increase in the population occurred. The largest number of birds is usually seen during December when the local population is supplemented by migrants from the north. However, during February when the geese are seeking nesting sites, the birds are scattered, and the number of geese sighted at the K-25 Site decreases through the end of March, when the parents with their broods are evident and begin congregating near the ponds and streams associated with the K-25 Site.

During the June 1993 round up of Canada geese on the ORR and adjacent areas, 540 geese were captured. Many of the geese were recaptures and had leg bands and throat collars from previous years. Of the total geese captured, 273 were fitted with leg bands and throat collars. This is far fewer than the 500 geese that received throat collars and leg bands in 1992. During the round up, 43 geese were captured at the K-25 Site, 25 were recaptures and the remainder were fitted with throat collars and leg bands. This number, too, was smaller than the number usually captured at the K-25 Site; however, a large flock was on Poplar Creek and could not be captured. Data collected from the weekly census of geese are being used in a population model to estimate the probability that a hunter will harvest a goose that has lived on the ORR.

\section{Contaminants in Canada geese}

The five Canada geese collected near the K-1007B pond had been observed at the K-25 Site for 1 to 5 years. During this period, these geese were also observed at other areas. By having the census data we were able to establish the long term association of individual geese with the pond ecosystem. 


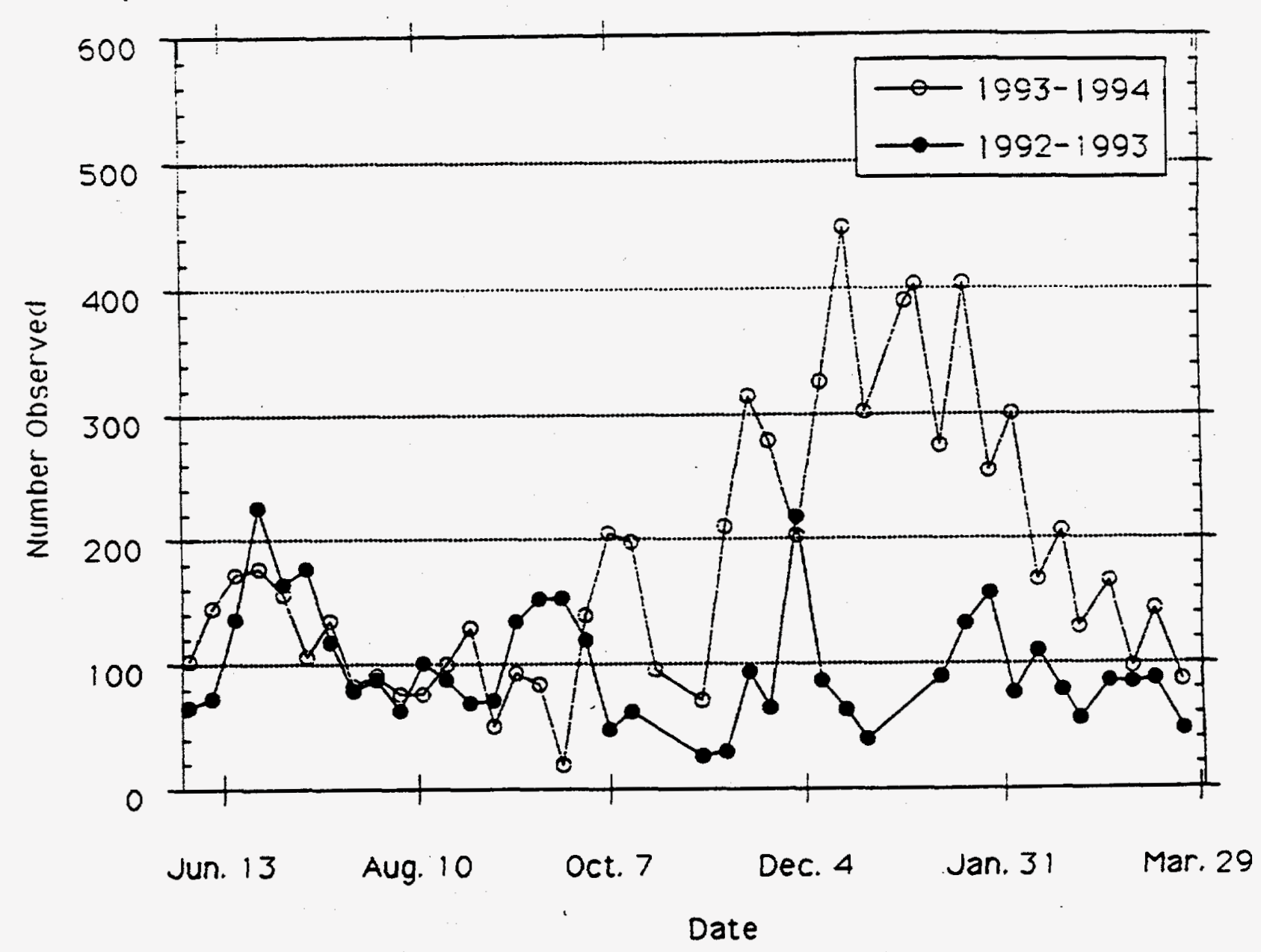

Fig. 4.3. Number of Canada geese observed at the K-25 Site during June 1993-March 1994, compared with numbers observed June 1992-March 1993. 
Breast and liver tissue from these ten geese were analyzed for PCBs. All samples were below the PCB limits of detection $(0.34 \mu \mathrm{g} / \mathrm{g})$. Tissues from these geese were also counted for ${ }^{137} \mathrm{Cs}$ and other radionuclides by a germanium detector. Of the 20 samples examined, measurable quantities were found in only 2 liver samples $(0.1$ and $0.2 \mathrm{pCi} / \mathrm{g})$ and $1 \mathrm{muscle}$ sample $(0.1 \mathrm{pCi} / \mathrm{g})$ from the Clinch River and 1 liver sample $(0.1 \mathrm{pCi} / \mathrm{g})$ from the $\mathrm{K}-25$ Site. Tissues from these geese are also being analyzed for other radionuclides and nonradiological contaminants.

\subsubsection{Conclusions and recommendations}

Very low to undetectable levels of PCBs and other contaminants occur in geese at the K-25 Site. Sufficient data have been collected to begin modeling of the Canada goose population. The census will be reduced to four sites (ORNL, the K-25 Site, the Y-12 Plant, and Melton Hill Dam). The Canada goose population at the K-25 Site will continue to be censused weekly. Contaminant levels will be monitored by collecting geese and other waterfowl annually for radiological and nonradiological analyses. Where contaminants are known to exist (ponds K-1007B and K-901A), additional samples will be taken and analyzed.

\subsubsection{Raccoon Bioaccumulation Monitoring (T. L. Ashwood)}

Raccoons consume a wide variety of prey and vegetation, some of which is from aquatic systems. Studies throughout North America have demonstrated the potential for raccoons to serve as indicator species for a wide range of contaminants including heavy metals, PCBs, organochlorine pesticides, and radionuclides (Ashwood 1993). During 1991, limited sampling of raccoons from the lower White Oak Creek watershed suggested that these animals could be used to monitor the bioavailability of ${ }^{137} \mathrm{Cs}$ to biota in the terrestrial ecosystem (Ashwood 1992). Based on this evidence, a long-term monitoring program was initiated using raccoons as ecological indicators of biologically available contamination-especially mercury and ${ }^{137} \mathrm{Cs}$ - in the terrestrial ecosystem.

This report presents data from the 1993 trapping of raccoons in the vicinity of the K-25 Site. 


\subsubsection{Methods}

Raccoons were trapped using cage traps baited with sardines or canned cat food. Animals caught during the spring generally had little, if any, fat, so sampling was continued during the fall, when raccoons are building up fat reserves.

In all trapping operations, raccoons were anesthetized with Ketaset (ketamine hydrochloride solution) prior to handling. Weight, gender, and some physical dimensions were determined, and as much fur as possible (typically $0.5-2 \mathrm{~g}$ ) was removed from the raccoon's tail. A biopsy sample of fat from the thigh area was removed for PCB analysis. Three raccoons in the K-25 Site area were fitted with radio collars for radiotracking to determine home range size and whether there was movement between areas upstream and downstream of the K-25 Site.

Fur samples were placed in plastic bags that were labeled with the sample identifier and collection date. Sample bags were generally kept frozen until rinsing or washing took place. Fat samples were placed in $20 \mathrm{~mL}$ scintillation vials and frozen immediately after collection.

Fur samples were washed using a 20-min mechanical agitation in a dilute solution of Prell $^{\circledast}$ shampoo in deionized water $(\sim 250 \mathrm{~mL})$ followed by three rinses in $\sim 250 \mathrm{~mL}$ of deionized water. During each rinse, the hair and water were mechanically agitated for $20 \mathrm{~min}$. A different, acid-cleaned bottle and fresh deionized water were used for each rinse. After the final rinse, each fur sample was air dried at $60^{\circ} \mathrm{C}$ for $\geq 16 \mathrm{~h}$ and then immediately sealed hermetically in a 93-cc plastic-lined aluminum can that had been previously labeled and tared. The sealed can was cooled for $\geq 30 \mathrm{~min}$ in a desiccator prior to the final weighing.

Samples were submitted to an external laboratory for trace metal ( $\mathrm{As}, \mathrm{Cd}, \mathrm{Hg}, \mathrm{Pb}, \mathrm{Se}$ ) and PCB analyses. Trace metals were analyzed by graphite furnace atomic absorption spectrometry (except $\mathrm{Hg}$, which was analyzed by cold vapor atomic absorption). Preparation blanks of deionized water and shampoo were also analyzed for metals. Fat samples were extracted with methylene chloride, dried, and cleaned up using alumina and silica gel and gel permeation chromatography, and analyzed by a capillary column gas chromatograph coupled to an electron capture detector.

\subsubsection{Results}

In May 1993, seven raccoons were captured along the reach of East Fork Poplar Creek between Lambert Quarry and the confluence with Poplar Creek. During this period only two 
raccoons were captured downstream of the K-25 Site along Poplar Creek. During September and October, an additional five raccoons were captured in each area.

No results of metals or PCB analyses were available at report time and will be presented in the quarterly report(s) following receipt and analysis of the data.

\subsubsection{Whole-Body Analyses of Representative Prey Fish}

Other K-25 bioaccumulation studies focus on bioaccumulation of mercury and PCBs in filets of sunfish because such samples are representative of human exposure to the contaminants and because sunfish can be used to assess differences in contaminant bioaccumulation among different sites. However, terrestrial predators tend to consume the entire fish rather than just the filet, so the whole-body burden of the fish is more representative of the dose received by these animals.

The purpose of this task is to determine whether representative prey fish from the K-25 Site are contaminated with PCBs and trace metals at levels of concentration that may be toxic to sensitive, piscivorous wildlife (e.g., mink). The original BMAP plan called for collection of stonerollers (Campostoma anomalum) from the K-1007-P1 pond and from Poplar Creek downstream from Mitchell Branch (Sect. 2.2.3.4 in Kszos et al. 1993). However, field researchers from other BMAP tasks discovered that stonerollers were not present at these sites in sufficient quantities to provide an adequate sample size. Therefore, gizzard shad (Dorosoma cepedianum) were selected as the representative prey species. Gizzard shad have relatively high concentrations of lipids, so they should accumulate PCBs, and they are an abundant prey fish.

Ten gizzard shad were collected by electrofishing at the K-1007-P1 pond (where largemouth bass contained high levels of PCBs) and near Mitchell Branch on Poplar Creek. The fish were frozen and homogenized. Representative aliquots were submitted to the Analytical Services Organization at ORNL for metals and PCB analyses. See Sect 4.1.2 for further details on methodology.

\subsubsection{Results}

Analytical results were not available at report time and will be presented in the quarterly report(s) following receipt and analysis of the data. 


\section{ASSESSMENT OF FISH HEALTH (TASK 3) \\ S. M. Adams, W. D. Crumby, and M. S. Greeley, Jr.}

\subsection{BIOINDICATORS SUBTASK (S. M. Adams and W.D. Crumby)}

This report presents the results of the 1989-1992 bioindicator studies conducted in Mitchell Branch and three reference streams and also evaluates temporal changes in the health of fish populations in Mitchell Branch from 1989 to 1992. As a representative indicator of the health of the Mitchell Branch system, redbreast sunfish (Lepomis auritus) has been the single target fish species for this BMAP task since 1989. The redbreast sunfish is especially suited for assessing the ecological health of Mitchell Branch because of its relative abundance and position at the top of the food chain in this stream. Because of their position in the food chain, these fish are integrators of environmental conditions and may reflect, therefore, the overall health of the stream ecosystem.

In this study, an integrative approach has been taken to investigate holistic responses of fish to environmental stressors and to aid in the identification of causative agents or mechanisms that may be affecting the health of fish populations in Mitchell Branch.

Many ecotoxicological studies dealing with the biological effects of environmental stressors, such as contaminants, use measurements of one or more variables to evaluate the response of organisms to these stressors. Whereas single variable responses may reflect specific structural or functional attributes of an organism, usually at a particular level of biological organization, these single responses do not provide an integrated measure of the effects of stressors on organism health (Adams and Ryon, in press). If single variable measurements are analyzed separately, then the interrelationships among the observed variables are not considered in evaluating an organism's response to stress. Although the complexity of analysis and interpretation may be greater in multivariate analysis, statistical approaches that use integrated multivariate analysis take into account the interrelationships and associations that exist among variables. Therefore, multivariate approaches more accurately reflect the myriad of interactions that occur between the organism and the environment than do single variate approaches (Cairns and van der Schalie 1980, Capuzzo 1985, Heath 1987). The complexity of ecological systems, such as Mitchell Branch, dictate that a holistic approach be taken in evaluating the effects of environmental stressors in these systems. 


\subsubsection{Methods}

\subsubsection{Sampling procedures}

Sampling was conducted during spring-summer periods of 1989-1992 in Mitchell Branch (above weir) and three reference streams, including Brushy Fork, located between Oliver Springs and Clinton (Anderson County, Tennessee); Hinds Creek, between Clinton and Norris (Anderson County); and Paint Rock Creek (Loudon County, Tennessee). At each site, redbreast sunfish ( $L$. auritus) of all sizes and age groups were collected by electroshocking. Blood samples were taken from 12 to 15 of the larger male fish within 2 min after collection by puncturing the caudal vessels with a 20 -gauge needle. Blood samples of $\sim 0.7 \mathrm{~mL}$ were obtained from all fish by using unheparinized 3-mL vacutainers (Becton, Dickson, \& Co.). Each tube was labeled with a fish identification number and placed on ice for transport to the laboratory. All fish were processed for population-level analysis by recording their lengths and weights and removing a sample of scales for age and growth information. Fish not used for the blood and bioindicator analysis were returned to the stream alive.

\subsubsection{Analytical procedures}

Total lengths and weights were recorded for fish transported from the field, and observations were also made on the general condition of the fish, such as presence or absence of disease, body and/or mouth sores, external parasites, and general appearance. Following sacrifice, the liver and spleen were removed from each fish for further analysis. A $100-\mathrm{mg}$ section of liver was placed in a $20-\mathrm{mL}$ scintillation vial with $5-\mathrm{mL}$ of Bouin's fixative for histopathological analysis. The remaining viscera (minus liver and spleen) were excised from the body cavity, and their total weight was recorded after all food material was removed from the stomach and intestine. The liver- and visceral-somatic indices were calculated by dividing their respective weights by total body weight. The condition factor $(K)$ of each fish was calculated as $K=10^{5} W / L^{3}$, where $W$ is body weight (in grams) and $L$ is total length (in centimeters).

\section{Serum analysis}

Blood collected in the unheparinized tubes was allowed to clot, transferred with Pasteur pipettes to $1.5-\mathrm{mL}$ conical micro-centrifuge tubes labeled with the fish identification number, 
and centrifuged for $3 \mathrm{~min}$ in a Beckman Microfuge. The clear supernatant (serum) was drawn off with clean pipettes and transferred to labeled $1-\mathrm{mL}$ conical plastic tubes.

Indicators of organ dysfunction [creatinine, alanine aminotransferase (ALT), serum albumin, and blood urea nitrogen (BUN)] were analyzed following the methods described by Henry et al. (1974), Bergmeyer et al. (1978), Doumas et al. (1972), and Tiffany et al. (1972) respectively. Cholesterol was analyzed by the method of Allain et al. (1974), and triglycerides were analyzed by the procedure of Bucolo and David (1973). Total serum proteins were measured by the Biuret method (NCCLS 1979); the procedures for this assay are described in the Roche Diagnostic Systems (1986) information package. All of these methods are enzymatic assays; the reagents for each assay were obtained from Roche Diagnostic Systems.

All serum assays were performed with an automated Centrifugal Fast Analyzer System (CobasFara, Hoffman La Roche Instruments, Inc.). Calibrations were made by using the Roche serum calibrator as the standard and Moni-Trol-ES Level 1 and 2 (American Dade, Miami, Florida) as internal standards.

\section{Histopathological analysis}

The following histopathological analyses were performed by Dr. David Hinton of the School of Veterinary Medicine, University of California-Davis: (1) percentage of tissue occupied by parasites, (2) percentage of liver composed of necrotic parenchyma, (3) percentage of tissue composed of macrophage aggregates and (4) percentage of liver occupied by functional parenchyma. These analyses were performed by using methods described by Hinton and Couch (1984).

\section{Detoxification Enzymes}

Microsome isolation. Fish hepatic microsomes were prepared by differential centrifugation (McKee et al. 1983) with several modifications. Fish were sacrificed by severing the spinal cord, and the livers were immediately removed and blotted dry. Each liver sample was placed in ice-cold buffer (0.25 $\mathrm{m} M$ sucrose, $0.1 M$ tris, $\mathrm{pH} 7.4)$. The tissues were minced and then homogenized in 5 volumes of buffer with a motor-driven Potter-Elvehjem glass and Teflon homogenizer. The homogenates were centrifuged in a J-21B Beckman 
centrifuge at $3000 \mathrm{~g}^{*}$ for $10 \mathrm{~min}$ and at $10,000 \mathrm{~g}$ for $20 \mathrm{~min}$. The resulting supernatants were then centrifuged at $105,000 \mathrm{~g}$ for $60 \mathrm{~min}$ in a Beckman L3-50 ultracentrifuge. Microsomal pellets were resuspended in $0.1 \mathrm{M}$ tris buffer, $1 \mathrm{mM}$ EDTA**, and $20 \%$ glycerol at $\mathrm{pH} 7.4$ by sonication for 10-15 s with a Braun Sonic 1510 at $50 \mathrm{~W}$. All operations were performed at 0 to $4^{\circ} \mathrm{C}$. The microsomes were frozen with liquid nitrogen and stored at $-120^{\circ} \mathrm{C}$; no significant change in 7-ethoxyresorufin O-deethylase (EROD) activity was detected after 6 months of storage at this temperature. The activity of fish microsomes stored under these conditions has been reported to be stable for 1 year (Forlin and Anderson 1985).

Enzyme assays. The activity of EROD was measured fluorimetrically at $30^{\circ} \mathrm{C}$ (Burke and Mayer 1974) and expressed as moles of resorufin per minute per milligram of microsomal protein. The final reaction buffer contained $80 \mathrm{~m} M$ HEPES buffer (pH 7.8), $5 \mathrm{mM}$ magnesium acetate, $1.0 \mu M$ 7-ethoxyresorufin, $250 \mu M$ of reduced nicotinamide adenine dinucleotide phosphate (NADPH), and $100 \mu M$ EDTA. The concentration of total protein used in the enzyme assay ranged from 0.2 to $1.0 \mathrm{mg} / \mathrm{mL}$, depending on the activity of the sample. Proteins were measured by the Bio-Rad (Richmond, California) reagent method (Bradford 1976) with a Centrifugal Fast Analyzer System in which bovine serum albumin was used as a standard. Cytochrome P-450 and cytochrome $b_{s}$ content were each measured by their characteristic oxidized and reduced spectra. Cytochrome P-450 samples were oxidized with carbon monoxide and reduced with sodium dithionite (Johannesen and DePierre 1978). Cytochrome $b_{5}$ was reduced with $\mathrm{NADH}$, and the $b_{5}$ assays were conducted prior to the P-450 analysis (Stegeman et al. 1979). NADPH-cytochrome $c$ reductase was assayed spectrophotometrically by the reduction of cytochrome $c$ using an extinction coefficient of $21.1 \mathrm{~cm} / \mathrm{m} M$.

\section{Population Evaluation}

Scale samples were used to determine the age and to estimate the growth of redbreast sunfish in Mitchell Branch and the three reference streams. Approximately ten scales were removed from each fish using small metal forceps. Scales were taken from the left side of the

"An italic, lowercase " $g$ " denotes the standard acceleration due to gravity ( $9.8 \mathrm{~m} / \mathrm{s})$.

${ }^{* *} E D T A=$ ethylene diaminetetrasetic acid. 
body near the tip of the pectoral fin and stored in $5.7 \times 8.9 \mathrm{~cm}$ coin envelopes. Total length (in centimeters), weight (in grams), species, sampling site, date, and tag number (if applicable) were recorded on each envelope. Fish were returned to the stream alive after scales were obtained and the length and weight were recorded.

In the laboratory, scales from each fish were arranged in rows between two cellulose acetate slides. The slides were pressed together using a hand-cranked laboratory press (Wildlife Supply Co.), which left an impression of each scale on one of the slides. Scale impressions were stored with scale samples in corresponding coin envelopes.

Scales were analyzed using a video image digitizing system. This system includes a dissecting microscope with video camera attachment, a $25.4 \mathrm{~cm}$ black and white video monitor, and the video digitizer. The digitizer was connected to a personal computer to allow data transfer to the growth analysis program, Disbcal (Missouri Department of Conservation 1989).

At the beginning of each scale analysis session, a file was opened in the Disbcal program to store new scale data. Scale impressions were placed on the microscope stage and viewed on the video monitor. For each scale impression, the tag number, total length, weight, age, and sex (if known), were entered into Disbcal. The distance from the focus to each annulus and to the scale edge was transmitted using the digitizer. Annuli were identified using the techniques outlined by Jearld (1983). A sample was excluded from analysis if scales exhibited abnormal form or if a large number of the scales had been lost and regenerated by the fish. Twenty percent of the scale samples from each site were read by a second individual for QA (verification) purposes.

Growth data were then analyzed using the files created during scale measurement. All back-calculations of fish length were made using the Fraser-Lee method (Fraser 1916 and Lee 1920), as follows:

$$
L_{i}=a+\frac{\left(L_{c}-a\right)}{S_{c}} S_{i} \text {, where }
$$

$\mathrm{L}_{\mathrm{i}}=$ calculated length at age $\mathrm{i}$;

$=$ intercept of seale radius vs fish length regression;

$L_{c}=$ length of fish at capture;

$S_{c}=$ radius of scale at capture; and

$S_{i}=$ scale measurement to annulus $i$. 
Fish were divided into $1-\mathrm{cm}$ size groups based on total length. Length frequency and age frequency histograms were developed for each population. Growth trends (based on total length at capture) were compared among sites for the years 1989-1992. For fish captured in 1992, a Tukey test (Zar 1984), was used to test for significant differences among sites in mean total length at capture $(p=0.05)$. Back-calculated length at age was also compared among sites for fish captured from 1990 to 1992.

\subsubsection{Statistical procedures}

To determine the integrated response of fish to the environmental conditions at each sampling site, bioindicator variables representative of five functional response groups were entered into a canonical discriminant analysis procedure (PROC CANDISC, SAS 1985b). Individual bioindicators were grouped into five functional categories representing indicators of (1) detoxification enzyme induction, (2) organ dysfunction, (3) histopathology, (4) overall fish health or condition, and (5) nutritional or feeding status. These functional groups reflect gradients of both ecological relevance and the time-course of a response to a stressor such as a contaminant (Adams 1990). Those variables in categories (1) and (2) are primarily short-term response indicators and have relatively low ecological relevance, whereas those in groups (3) through (5) are longer-term response indicators and are characterized by low toxicological but high ecological relevance (Adams 1990).

The canonical discriminant analysis procedure provides a two-dimensional graphic representation of the positions and orientations of the various responses of fish from each site relative to each other. In addition, this method derives a linear ranking of combinations of all variables and can identify statistically significant differences among treatment means even when single variables may not indicate such differences. A selection procedure for variables available in SAS (PROC STEPWISE, SAS 1985b) was used to identify the indicators that contributed most to the discrimination of fish health status among sites, based on the integrated parameters. This selection procedure for variables considered all possible combinations of the observed values and, for any specified subset size, selected those variables having the best discriminating power.

Procedures for canonical variate analysis are derived under the assumption that observations come from multivariate normal distributions with equal covariance matrices. 
Using the Shapiro-Wilk statistic (Conover, 1980), the normality assumption was evaluated by testing (for each sample population) the marginal univariate normality of the distribution for each variable. Because of the large number of tests involved, the level of significance of each test was adjusted using a Bonferroni modification, to control the overall level of significance (Johnson and Wichern, 1992). If marginal abnormality was indicated for a variable, then it was transformed (usually with the log transformation) to achieve a more nearly normal marginal distribution. Although marginal normality does not guarantee multivariate normality, the abnormality of the marginal distribution frequently reflects multivariate abnormality. The homogeneity of the covariance matrices was tested using Bartlett's test for equal covariance matrices (Seal, 1964). This test is very sensitive to the normality of the variable distributions for each population (Johnson and Wichern, 1992).

Two levels of analyses were conducted to evaluate the effects of water quality and other environmental stressors on the health of fish in Mitchell Branch. The integrated bioindicator analysis was used to determine the overall health response of fish at both impacted and reference sites, and age and growth analyses were used to compare fish population health among streams.

\subsubsection{Results and Discussion}

\subsubsection{Integrated bioindicator analysis}

The integrated response of fish to the environmental conditions at each study site was evaluated by incorporating bioindicators representing five functional response categories in the multivariate analysis. This multivariate approach allows the health of fish populations at each sample site to be evaluated within a holistic or integrated framework. In addition, this is a useful approach for determining the effectiveness of remedial actions on aquatic ecosystem health.

Results of the canonical discriminant analysis procedure revealed several patterns relative to the health of the redbreast sunfish population in Mitchell Branch compared to the health of fish at the three reference sites. In all years (1989-1992) the integrated health response of fish collected from Mitchell Branch was distinct from that of sunfish collected from the reference sites (Figs. 5.1-5.4). The integrated response of Mitchell Branch fish for each year always 


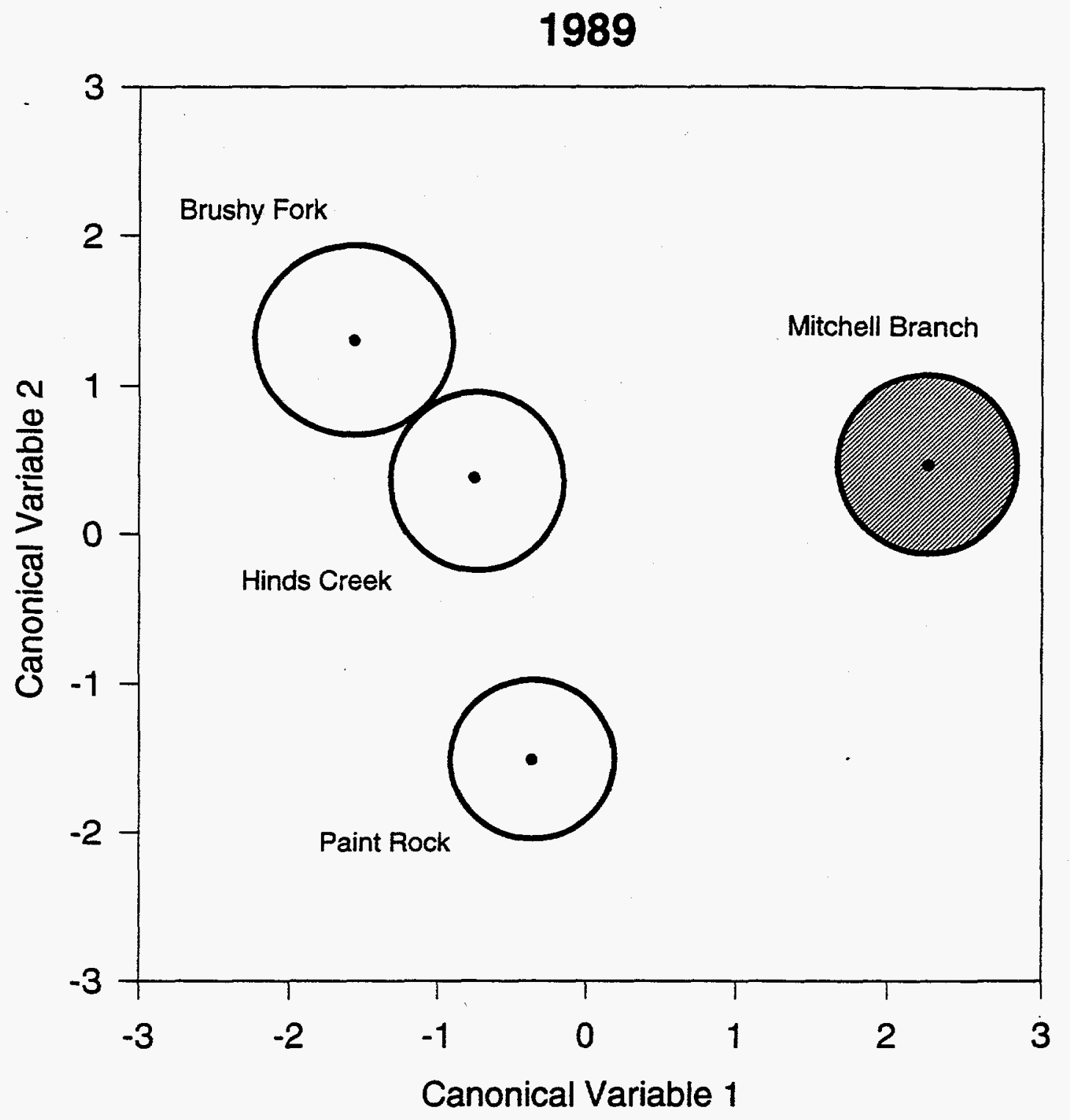

Fig. 5.1. Segregation of integrated health responses for male redbreast sunfish collected in 1989 at Mitchell Branch and three reference streams. Circles represent site means and the $95 \%$ confidence radii of the site-year means. 
1990

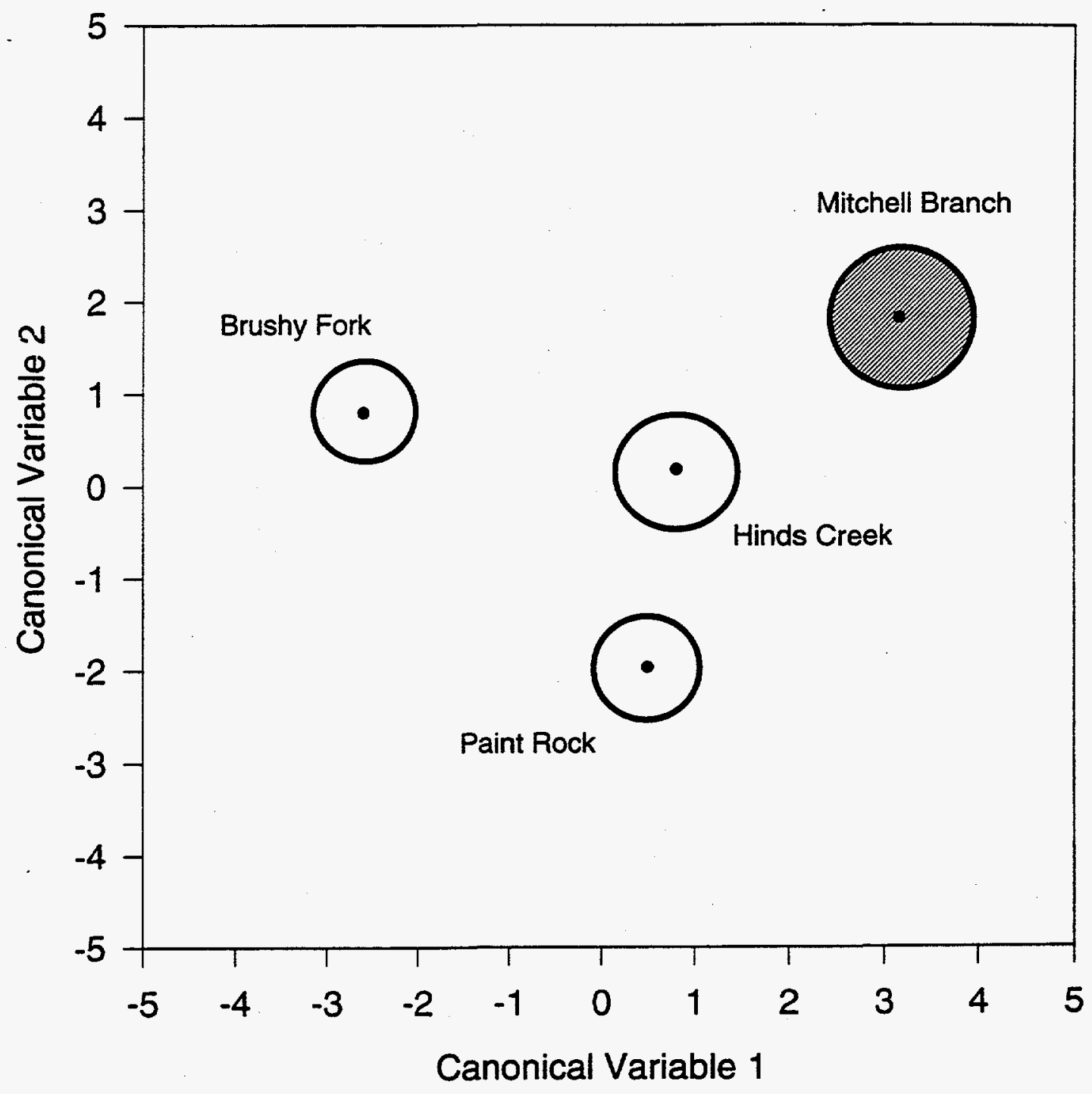

Fig. 5.2. Segregation of integrated health responses for male redbreast sunfish collected in 1990 at Mitchell Branch and three reference streams. Circles represent site means and the $95 \%$ confidence radii of the site-year means. 


\section{1}

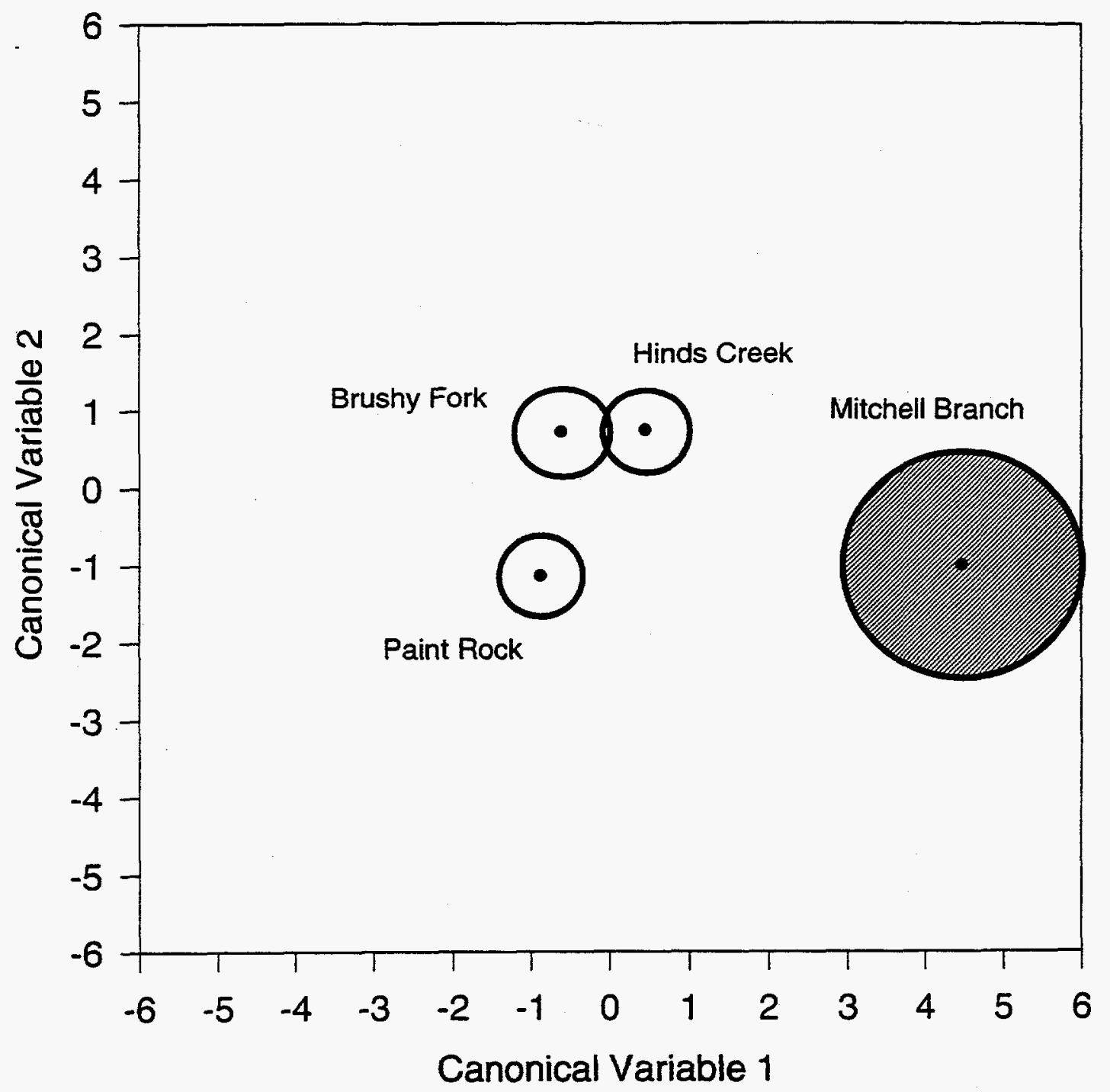

Fig. 5.3. Segregation of integrated health responses for male redbreast sunfish collected in 1991 at Mitchell Branch and three reference streams. Circles represent site means and the $95 \%$ confidence radii of the site-year means. 


\section{2}

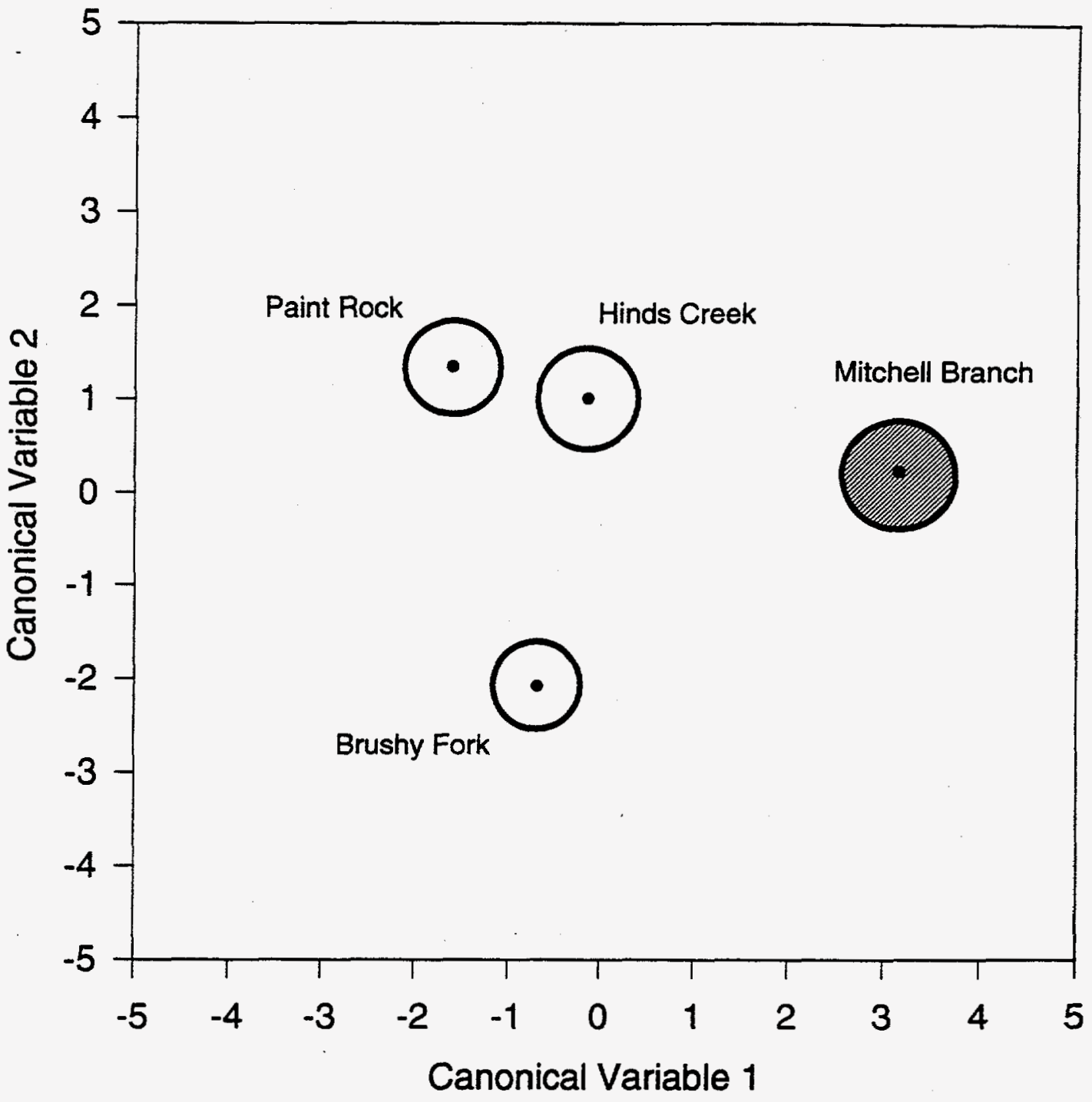

Fig. 5.4. Segregation of integrated health responses for male redbreast sunfish collected in 1992 at Mitchell Branch and three reference streams. Circles represent site means and the $95 \%$ confidence radii of the site-year means. 
occurred on the right side of the discriminant function plot, while the reference site responses cluster at the middle on the left side of the discriminant plot (Figs. 5.1-5.4).

In general, there is a higher similarity in integrated responses among reference sites within each year than there is between the reference sites as a group and Mitchell Branch. In fact in 1989 and 1991, Brushy Fork and Hinds Creek were very similar in their overall response as indicated by the close proximity of the $95 \%$ confidence radii of the site means (Figs. 5.1 and 5.3). In all years except 1992, Paint Rock Creek tended to be rather dissimilar from the other two reference sites even though it still maintained its distinct dissimilarity to Mitchell Branch.

The fact that all three reference sites were relatively similar to each other in at least two of the study years (1989 and 1991) and fish from Mitchell Branch were consistently segregated from the reference groups for each of the 4 years provides convincing evidence that the Mitchell Branch fish are being differentially affected by environmental stressors in that system. As long as the integrated response of fish from Mitchell Branch can be distinguished statistically (see Table 5.1) from the reference site response group, this would indicate that fish in Mitchell Branch are in an unhealthy state compared with fish from the reference streams.

Table 5.1. Statistical linear distances (Mahalanobis distances) between the integrated bioindicator responses of fish collected from Mitchell Branch and each reference from 1989 to 1992

\begin{tabular}{ccccc}
\hline & \multicolumn{4}{c}{ Reference Sites } \\
\cline { 2 - 4 } 1989 & Brushy Fork & Hinds Creek & Paint Rock Creek & Mean \\
\cline { 2 - 4 } 1990 & 13 & 15.5 & 10.8 & 11.9 \\
1991 & 20 & 34 & 22 & 18.7 \\
1992 & 15 & 29 & 29 & 26 \\
\hline Mean & 14.4 & 20 & 24 & 14.7 \\
\hline
\end{tabular}

Based on the relative positions of the integrated responses of Mitchell branch fish to the reference site fish over all years studied, there is little evidence to indicate that the health of Mitchell Branch fish has improved over this period (Figs. 5.1-5.4). Quantitative relationships between integrated site means can be demonstrated statistically with a measure of the 
differences between the midpoints of these site means. The Mahalanobis statistic is a measure of the linear difference in the distances between site means. Table 5.1 shows the statistical distances between Mitchell Branch and each reference site and illustrates that since 1989 no clear pattern has emerged relative to the temporal change in health of Mitchell Branch fish. For sunfish from Brushy Fork and Paint Rock Creek, the statistical distance between their integrated site means and that of Mitchell Branch increased from 1989 to 1991 then declined in 1992. This pattern demonstrated that from 1989 to 1991 the health of sunfish from Mitchell Branch became increasingly different from that of fish from these two reference areas. In 1992, however, the linear distance decreased, indicating increasing similarity in health between the reference sites and Mitchell Branch from 1991 to 1992 . When the mean for each year is calculated across all three reference sites, a similar pattern is noted; namely a progressive decrease in health of Mitchell Branch sunfish from 1989 to 1991 and an increased health status in 1992.

Activities to remediate the quality of surface waters at the K-25 Site have been ongoing since 1991. For example, since 1991 dechlorination of the major storm drains has occurred, which may account for the improved fish health seen in 1992. This action may explain, in part, the improvement in fish health observed after 1991.

\subsubsection{Health indicator responses}

For each year, the individual response variables that best discriminated among the health status of fish from the four sample sites were identified by a multivariate selection procedure. These variables were used to generate the integrated responses at sites shown in Figs. 5.1-5.4. Over all 4 years, a total of ten bioindicators were identified as being important in discriminating among site responses. Indicators from three of the functional response groups are represented, including those from the detoxification enzyme group (EROD, NADPH, and microsomal protein), organ dysfunction group (albumin, serum protein, blood urea nitrogen, and creatinine), and the condition indices (the visceral- and liver-somatic indices) (Table 5.2). In 1989, EROD, an indicator of contaminant exposure, was the variable most responsible for discriminating among sites, followed by two organ dysfunction indicators (albumin and blood urea nitrogen) and the liver somatic index. 
Table 5.2. Ranking of bioindicator response variables that were significant in discriminating among the four sample sites each year

\begin{tabular}{lcccc}
\hline Bioindicator & 1989 & 1990 & 1991 & 1992 \\
\hline EROD & 1 & 3 & 1 & 6 \\
NADPH & 2 & 2 & & 5 \\
Albumin & & 1 & 2 & \\
Serum Protein & & 3 & 3 \\
Microsomal Protein & & 4 & & 4 \\
Visceral Somatic Index & 5 & 5 & & 2 \\
Liver-Somatic Index & 3 & 6 & & 1 \\
Blood Urea Nitrogen & & & 4 & 7 \\
Condition Factor & & & \\
Creatinine & & & \\
\hline
\end{tabular}

The activities or levels of liver detoxification enzymes are used to indicate exposure to various xenobiotics, such as polycyclic aromatic hydrocarbons (PAHs), polychlorinated biphenyls (PCBs), and pesticides (Payne and Penrose 1975). Many of these compounds commonly occur in industrial and municipal effluents and are accumulated within living tissues (Ahokas et al. 1976, Neff 1978, Brown et al. 1986). Of the detoxification enzymes measured, EROD has been shown to be the best indicator of toxicant exposure in fish collected from other contaminated systems (Adams et al. 1992a; Adams et al. 1992b). Serum albumin promotes the transport of insoluble or sparingly soluble compounds, such as fatty acids, bilirubin, and hormones, across the cell membranes. This protein is also involved with osmotic regulation and can be used as a reserve source of protein and amino acids. Blood urea nitrogen (BUN) is the major end product of protein nitrogen metabolism in mammals and is generally used in the medical profession to diagnose renal disorders. Fish, however, produce a more diverse array of compounds as nitrogenous waste including, but not limited to, ammonia and urea. In addition to being excreted by the kidneys, some ammonia and urea is also excreted through the gills. In diagnosing, therefore, the effects of stress on fish, abnormal levels of urea in the blood may serve as an important indicator of gill dysfunction. The liversomatic index (LSI) reflects both short-term nutritional status and metabolic energy demands (Heidinger and Crawford 1977, Adams and McLean 1985). The LSI is also sensitive to 
toxicant stress, and liver enlargement resulting from hyperplasia (increase in cell number), and hypertrophy (increase in cell size) has been reported in fish exposed to toxic compounds (Fletcher et al. 1982, Heath 1987, Addison 1984).

A different set of indicators were important, however, in 1990 for among-site discrimination. Surprisingly, EROD was not an important distinguishing variable in 1990. However, two organ dysfunction indicators, serum protein and albumin, were the most influential variables. After these two variables, a detoxification enzyme, NADPH, entered into the discrimination process followed by two condition indices, the visceral- and liver-somatic indices. The visceral-somatic index (VSI) provides information on energy stored as lipids in the mesenteries of the viscera. These lipids are important for long-term energy use and gonad maturation (Adams and McLean 1985). Additionally, the VSI generally reflects the level of total body lipids, which is used to indicate overall fat storage and general nutritional status of the fish.

Again, in 1991, a detoxification enzyme was the most influential discriminating variable followed in order by serum protein (which was the first most important variable in 1990), microsomal protein, and the condition factor. Microsomal protein is another indicator of detoxification enzyme induction in the organism and the condition factor is important for reflecting the overall condition of the organism. The condition factor (CDFC) is a generalized indicator of the overall health or plumpness of a fish and can reflect the integrated effect of both nutritional status and metabolic impairment caused by stress.

In 1992, as in 1990, detoxification enzymes played a reduced role in discrimination among sites. Even though microsomal protein, NADPH and EROD were ranked 3rd, 5th, and 6 th, respectively, in importance, organ dysfunction and condition index variables were the most influential discrimitory variables.

It is evident from this analysis of health response indicators that there is no apparent consistency among years in the importance of variables relative to intra-year site discrimination (Table 5.2). Each year was characterized by a unique set of site discriminatory variables. In 1989 and 1991, EROD was the most important variable, but in 1990 and 1992 organ dysfunction variables headed the list. Albumin was important in 1989 and 1990 but not in 1991 and 1992. Serum protein was a significant variable in 1990 and 1991 but not in 1989 and 1992. Similarly, the condition indices were somewhat important in 1992 but not in 1989. 
A reasonable interpretation of this inconsistent pattern in the importance of health response variables among years is that Mitchell Branch has been subjected to not only a variety of stressors over time but that the action of these stressors on the system may be episodic or periodic in nature. If, in fact, organisms in Mitchell branch are exposed to chronic consistent levels of the same contaminant or groups of contaminants, then we would expect to see a relatively consistent pattern in response variables across years. For example, relatively consistent patterns in bioindicator response variables have been observed in both East Fork Poplar Creek and White Oak Creek over the past several years even though the magnitude of the responses has declined somewhat over time (Hinzman et al. 1993; Ashwood et al. 1994). We might conclude, therefore, that the health of the fish populations in Mitchell Branch may be influenced primarily by episodic events that occur in that system, either by periodic releases of contaminants or by other unknown activities or events that occur within the Mitchell Branch watershed. In addition, the primary stressors involved in these episodic events may not be the same across time. Future studies should identify and confirm not only the effects of continued remedial activities on fish population health in Mitchell Branch but also the relative importance of episodic events in influencing the health status of important aquatic organisms.

\subsubsection{Population-level analysis}

Length-frequency histograms were used to evaluate the size distribution of redbreast sunfish in Mitchell Branch from 1989-1992 (Fig. 5.5). The structure and size of the redbreast sunfish population in Mitchell Branch has changed over the last several years. Only 25 redbreast sunfish were collected in 1989. All of these fish were larger than $11.0 \mathrm{~cm}$, indicating an imbalance in the population. Reproductive impairment, recruitment failure and inadequate spawning substrate were suggested as possible reasons for the small number of redbreast sunfish present in 1989 (Smith et al. 1994). However, in subsequent years, the number of fish collected has increased and the size structure has become more evenly distributed. In 1992, 130 redbreast sunfish were collected, ranging in size from 6 to $22 \mathrm{~cm}$. This distribution of sizes was considered balanced and was similar to the size distributions of redbreast sunfish found in the reference streams.

Age-frequency histograms were used to aid in the evaluation of year class strength (Fig. 5.6). The age structure of the population has remained relatively stable, with fish up to 5 years of age collected each year since 1989. However, fish older than age 3 seem to be less 


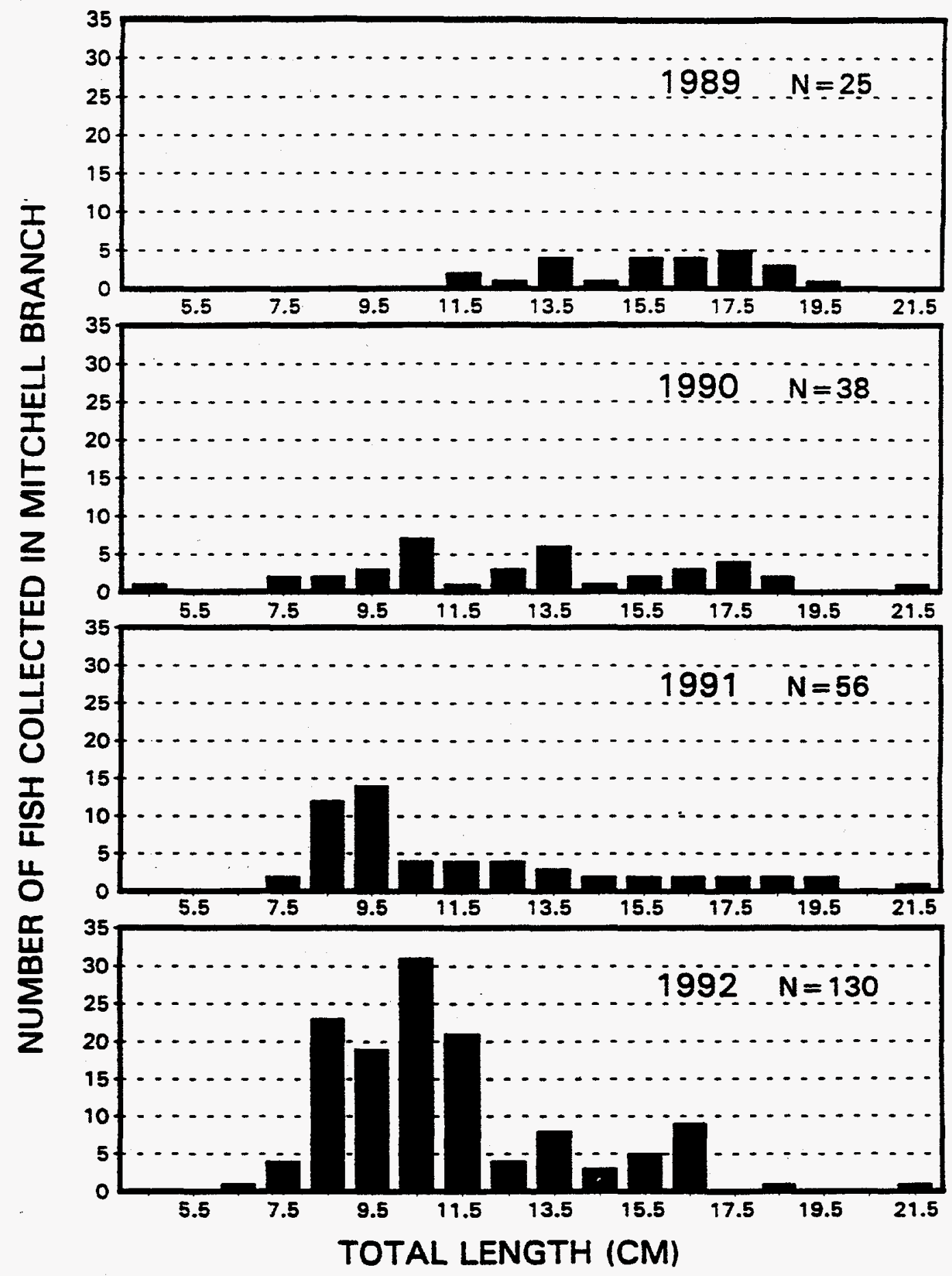

Fig. 5.5. Length frequency of redbreast sunfish collected in Mitchell Branch from 1989 to 1992. 


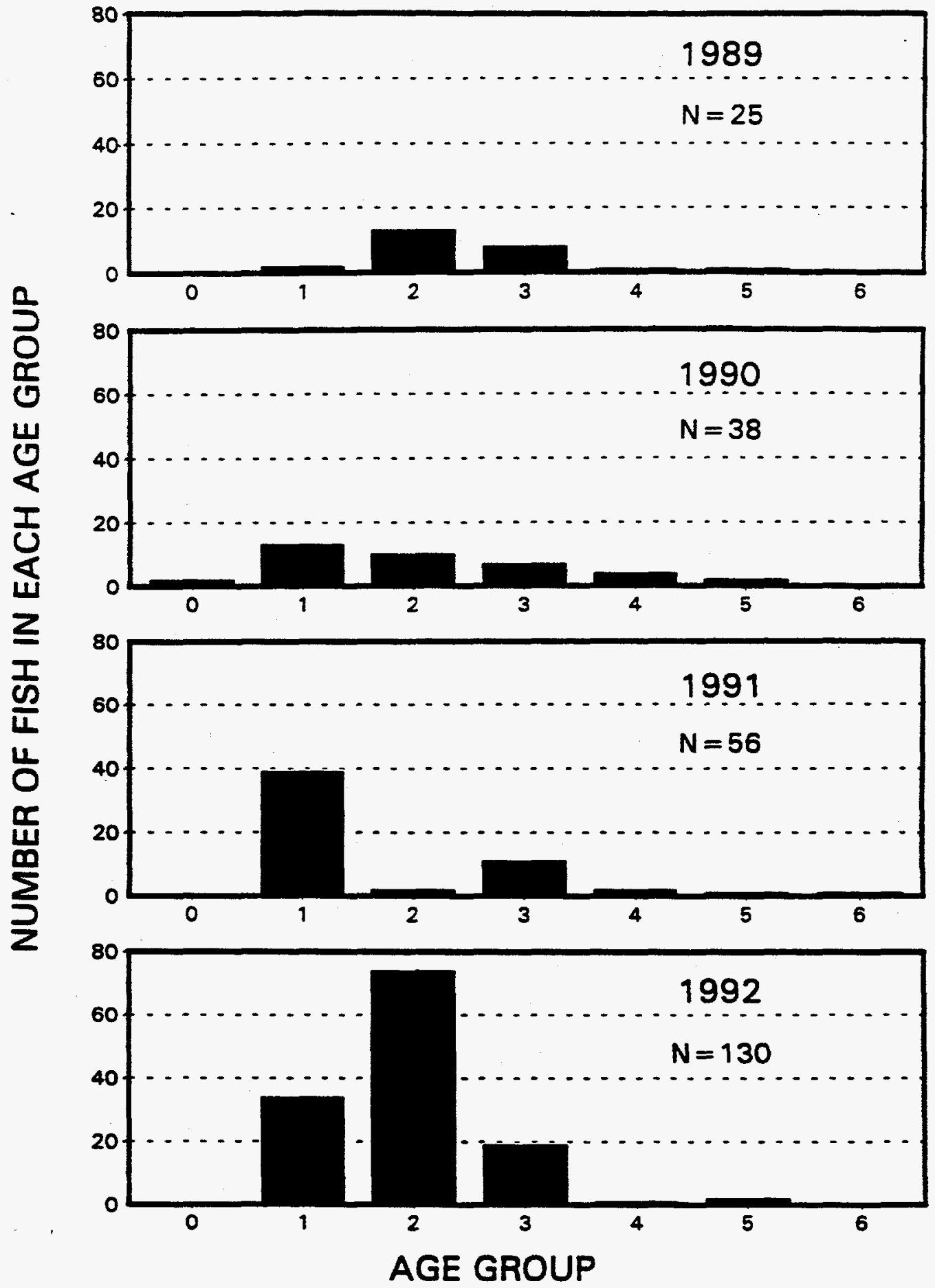

Fig. 5.6. Age frequency of redbreast sunfish collected in Mitchell Branch from 1989 to 1992. 
common in Mitchell Branch than in the reference sites. In 1992, only 3 fish >age 3 were found in Mitchell Branch. In contrast, fish from the 1990 year class (age 2) made up $57 \%$ of the population, indicating an exceptionally successful spawning season in 1990 . The silt and mud substrate of Mitchell Branch is apparently adequate for successful nesting of redbreast sunfish. Fluctuations in year class strength are more likely related to changes in seasonal flow patterns. Fluctuations in stream discharge can have a major effect on recruitment, growth, and survival of redbreast sunfish (Aho et al. 1986).

\section{Growth Analysis}

Total length (TL) of a particular age class at capture was used as an indicator of the cumulative growth history of redbreast sunfish from each site. Because fish at all sites were collected over a short period of time (7-10 days), any differences in mean TL at capture indicated differences in growth rates among sites. In 1989, redbreast sunfish in Mitchell Branch were exceptionally large when compared with reference site fish of the same age (Fig. 5.7). In each subsequent year, TL at capture decreased for Mitchell Branch redbreast sunfish, and size differences at age diminished relative to the reference sites. In 1992, there was no significant difference in TL at capture between fish from Mitchell Branch and Paint Rock Creek for any age group (Table 5.3).

Back-calculation of TL at annulus formation was also used to characterize growth trends from previous years. Sample sizes are increased in each age group when using this method because data from each sampling year are combined to calculate mean TL at age. The value of the intercept " $a$ " that was used in back-calculations of fish length gave the best straight-line relationship for the regression of fish TL and scale radius (Carlander 1982). An intercept value of $24 \mathrm{~mm}$ was used in these calculations based on body-scale relationships from previous studies (Loar et al. 1993). The "a" of $24 \mathrm{~mm}$ was determined to be a good standard for use in growth analysis of redbreast sunfish populations in Mitchell Branch and the reference sites. Back-calculated lengths at age were generally larger for Mitchell Branch fish compared with reference site fish (Fig. 5.8). This was due to the higher growth rates that occurred before the fish population density increased in Mitchell Branch. In future years, back-calculated lengths for Mitchell Branch fish should decrease to reflect current growth rates, which are more similar to the reference sites. 


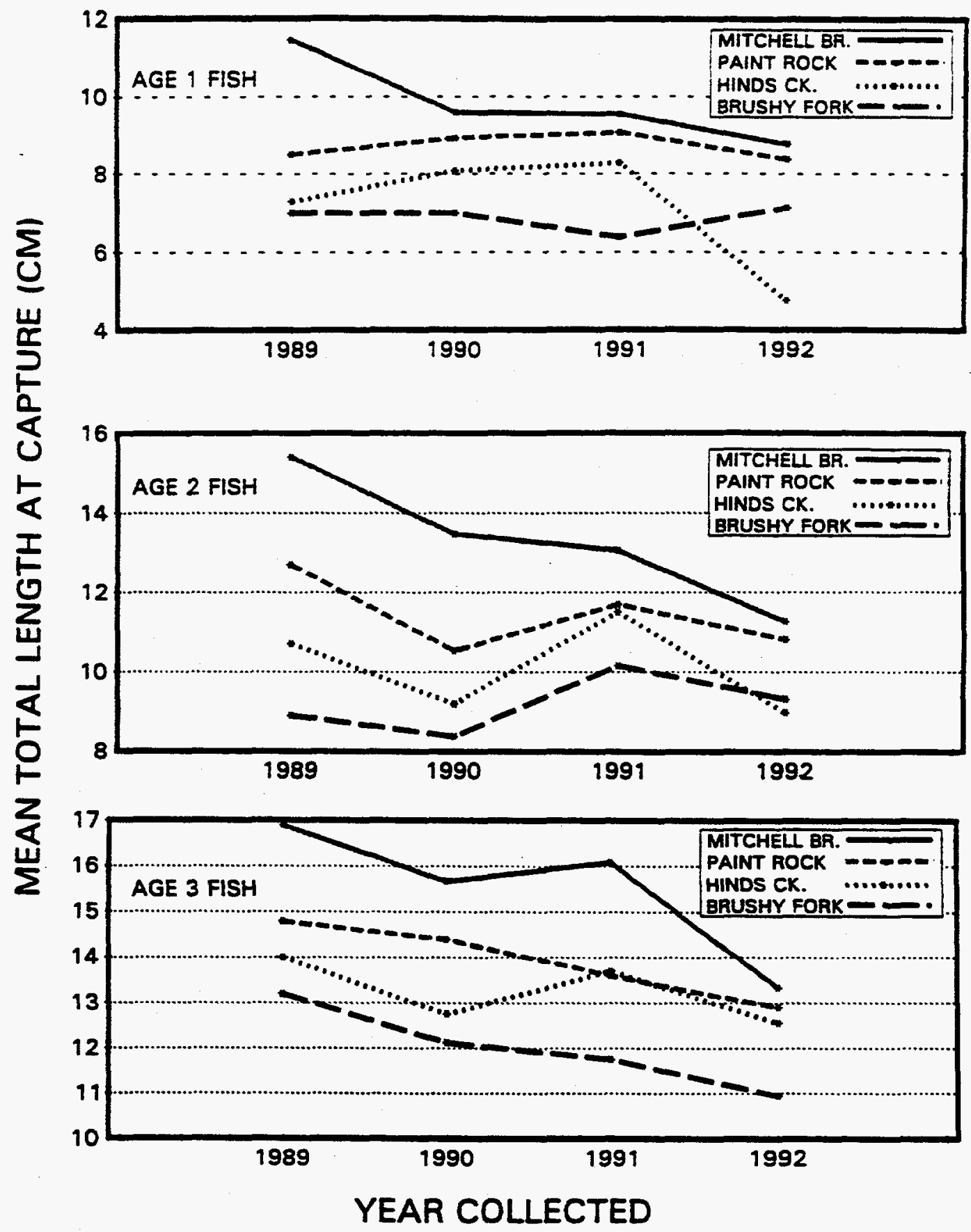

Fig. 5.7. Mean total length at capture (in centimeters) for redbreast sunfish collected in Mitchell Branch from 1989 to 1992. 
Table 5.3. Comparison of mean total length of redbreast sunfish at capture

Means with different alphabetical characters are significantly different from each other $(p=0.05)$

\begin{tabular}{|c|c|c|c|}
\hline Site & $\mathbf{N}$ & Mean & $\begin{array}{c}\text { Tukey test } \\
\text { result }\end{array}$ \\
\hline \multicolumn{4}{|c|}{ Age 1} \\
\hline Mitchell Branch & 34 & 8.76 & $\mathrm{a}$ \\
\hline Paint Rock Creek & 19 & 8.37 & $\mathrm{a}$ \\
\hline Hinds Creek & 5 & 4.76 & $\mathrm{~b}$ \\
\hline Brushy Fork & 3 & 7.13 & a \\
\hline \multicolumn{4}{|c|}{ Age 2} \\
\hline Mitchell Branch & 74 & 11.26 & a \\
\hline Paint Rock Creek & 40 & 10.81 & $\mathrm{a}$ \\
\hline Hinds Creek & 22 & 8.97 & $b$ \\
\hline Brushy Fork & 14 & 9.30 & $\mathrm{~b}$ \\
\hline \multicolumn{4}{|c|}{ Age 3} \\
\hline Mitchell Branch & 19 & 13.34 & a \\
\hline Paint Rock Creek & 22 & 12.91 & a \\
\hline Hinds Creek & 9 & 12.57 & $a b$ \\
\hline Brushy Fork & 48 & 10.94 & $b$ \\
\hline
\end{tabular}




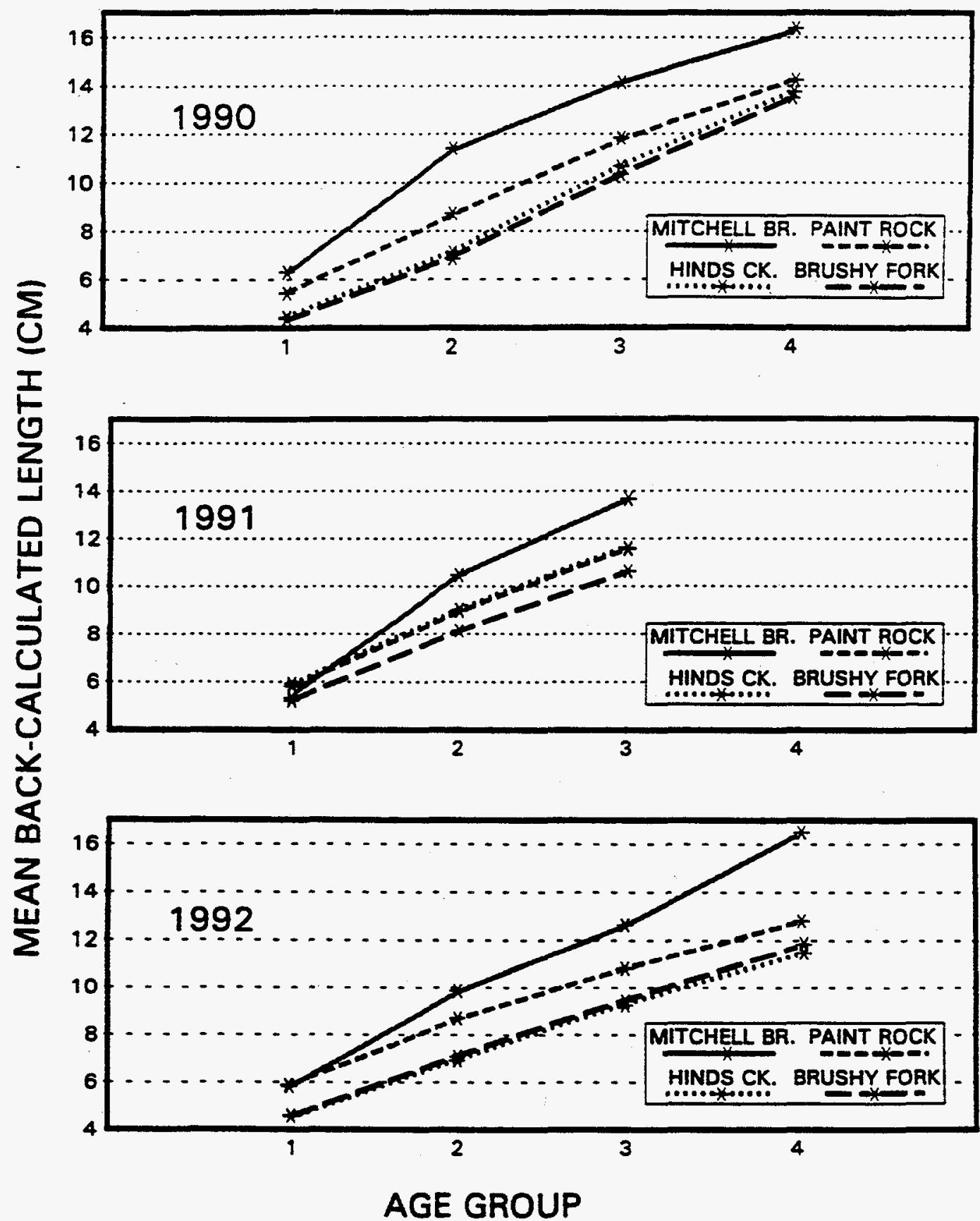

Fig. 5.8. Back-calculated length (in centimeters) at age for redbreast sunfish collected in Mitchell Branch from 1990 to 1992. 
Growth is known to be affected by population density, food availability, habitat quantity and quality, or stream productivity. The interactions of these factors, among others, are the principal determinants of growth rates. The decline in TL at capture of Mitchell Branch redbreast sunfish from 1989 to 1992 was probably due to several variables. In 1989 fish abundance was low, resulting in decreased intra- and inter-specific competition for food and habitat. Growth rates were probably enhanced during this period of decreased competition. Adams et al. (1992a) found a similar pattern in growth of fish in the Pigeon River where competition was low. As the population density increased in Mitchell Branch, competition was probably increased, resulting in slower growth. Unlike the reference sites, Mitchell Branch may lack the necessary flow and substrate for good production of aquatic invertebrates. Studies by Smith (1994) in sections further upstream in Mitchell Branch indicate that the macroinvertebrate fauna is degraded in these areas. Instream conditions such as flow, food production and water quality may also have affected the growth of redbreast sunfish in Mitchell Branch as population numbers increased in later years.

\subsection{REPRODUCTIVE EFFECTS SUBTASK (MS. Greeley, Jr.)}

\subsubsection{Introduction}

A major objective of the K-25 Site BMAP is to demonstrate that the NDPES effluent limitations for the site protect and maintain the classified use of Mitchell Branch for the growth and propagation of fish and other aquatic life. To directly examine the effects of K-25 Site activities on fish propagation in Mitchell Branch and Poplar Creek, a reproductive effects subtask was initiated in 1993 as part of the Fish Health Assessment Task of the new

\section{K-25 Site BMAP.}

Fish reproduction involves a complex series of processes including gamete production, spawning and fertilization, and embryonic development and larval survival. This subtask assesses fish reproductive competence at a number of biological levels, including internal regulatory mechanisms (serum reproductive steroid concentrations), gamete quantity and quality (fecundity, oocyte atresia or death) and embryonic and early larval development (fish embryo-larval toxicity tests). 


\subsubsection{Methods}

\subsubsection{Fish sampling and processing}

As with the bioindicator subtask, the redbreast sunfish is the primary sentinel species for the instream monitoring of fish reproductive competence in Mitchell Branch. Detailed descriptions of the study sites and basic fish processing procedures for the entire Fish Health Assessment Task are provided elsewhere in this report (Sect. 5.1). Female sunfish were collected by electroshocking from lower Mitchell Branch and three reference streams in spring 1993 immediately prior to the breeding season. Fish were bled for the measurement of circulating concentrations of reproductive hormones. Total body lengths and weights were recorded, and following sacrifice of the fish by spinal ligation, gonads were removed and weighed. A gonadal-somatic index (GSI) was determined for each fish: GSI = [gonad weight $(\mathrm{g}) /$ total body weight $(\mathrm{g})] \times 100$. Weighed pieces of ovarian tissue were transferred to $20-\mathrm{mL}$ glass scintillation vials containing 10-mL Karnovsky's fixative for quantitative analysis of ovarian condition and fecundity.

\subsubsection{Gonadal assays}

Morphometric reproductive analyses were conducted on the weighed subsamples of sunfish ovarian tissue by methods described in Hinzman et al. (1992). The developmental stages of oocytes were recorded, and the presence of any atretic (dead or nonviable) oocytes noted. Results were expressed as the number of oocytes of a certain size-class or stage per gram of fish body weight. The "batch" fecundity, or number of eggs to be released during the first spawn of the breeding season, was calculated from the number of oocytes present in the leading clutch of synchronously developing oocytes.

\subsubsection{Radioimmunoassays}

Radioimmunoassay (RIA) is a procedure for measuring minute amounts of a substance in biological samples. Radioimmunoassay techniques for measuring $17 \beta$-estradiol (E2) and testosterone $(\mathrm{T})$ in redbreast sunfish plasma and serum were modified from Greeley et al. (1988). A detailed description of the RIA as conducted in this laboratory can be found in Hinzman et al. (1992). For quality control purposes, aliquots of plasma from previously assayed pools were run with each set of samples. Within-assay variation and between-assay variation were consistently less than $20 \%$. 


\subsubsection{Fish embryo-larval toxicity tests}

The Japanese medaka (Oryzias latipes), a small fish native to southeastern Asia, was employed to examine the effects of water from Mitchell Branch and Poplar Creek on fish embryo-larval development. This species has several advantages for use in laboratory developmental toxicity testing, including ease of maintenance in the laboratory, year-round availability of eggs, a long embryonic period with a resultant increase in sensitivity to many xenobiotics, and a clear embryo which facilitates observations of developmental abnormalities prior to hatching. Medaka are currently being employed in the BMAP for examining the effects on fish embryo-larval development of water from EFPC and WOC on the ORR, and in the Clinch River Environmental Restoration Program for examining the developmental toxicity of water from Poplar Creek and the Clinch River.

Procedures associated with the medaka embryo-larval test are described in detail elsewhere (Ashwood et al. 1993). Briefly, recently fertilized eggs from 20 to 30 female medaka were pooled, randomized, and then assigned to treatment groups that included grab samples of ambient water sources or laboratory controls. Embryos were examined daily under a dissecting microscope for developmental abnormalities and scored for survival. Water renewal and changes through the first 7 days of a test followed the protocol of the ESD Toxicology Laboratory (see Sec.3.1.2); thereafter, water changes were conducted every other day using water from the final grab sample that was stored and refrigerated in the dark. All embryos were monitored until death, to 48 hours post-hatch, or through 21 days postfertilization. Study sites for medaka embryo-larval testing included several locations along Poplar Creek (see Sec. 3.1.2), as well as sites along Mitchell Branch upstream (MIK 1.43) and downstream (MIK 0.12) of the major K-25 Site discharges into this stream.

\subsubsection{Statistical analysis}

ANOVA was used to test for site effects related to the various reproductive parameters. If the ANOVA rejected a multisample null hypothesis of equal means, then Tukey's test (Zar 1984) was used to test for significant differences in response parameters at sites. The significance level for rejecting the hypothesis of equal means between sites was set at $p=0.05$. Tests for homogeneity of variance of individual response variables between sites were conducted using Levene's test (Sokal and Rohlf 1981), an F-distribution test that compares the ratios of the variances from two independent sample populations. Results of the 
medaka embryo-larval tests were examined by Chi-square analysis, with significant differences $(p=0.05)$ between sites determined by comparison of sample proportions as described in Daniel (1987).

\subsubsection{Results and Discussion}

\subsubsection{Instream reproductive effects}

Six reproductive indicators, representing several different levels of reproductive organization, were examined in female redbreast sunfish sampled from Mitchell Branch and three reference sites prior to the beginning of the 1993 breeding season (Table 5.4). The first of these parameters, the GSI, is a measure of the size of the sunfish ovary relative to body size and an indirect indicator of gamete quantity. The GSI indicated that the ovaries in sunfish from Mitchell Branch were significantly $(p<0.05)$ larger than the ovaries of fish from each of the three reference sites. Along with the GSI, determinations of fecundity and the abundance of vitellogenic or yolk-laden oocytes in ovaries serve as indicators of relative reproductive effort. Both fecundity and vitellogenic oocyte abundance were also significantly higher in fish from Mitchell Branch.

Atretic oocytes are indicators of gamete quality rather than quantity and may be one of the better reproductive indicators of an actual pathological condition. Many potential environmental contaminants, including PAHs (Krarup 1969, Mattison et al. 1983, Takizawa et al. 1984) and metals such as cadmium (Mattison et al. 1983), are known to damage developing oocytes. Relatively high incidences of oocyte atresia have been observed in redbreast sunfish from both upper EFPC below the Oak Ridge Y-12 Plant (Hinzman et al. 1992) and the Pigeon River, a stream heavily impacted by effluents from a paper and pulp mill (Adams et al. 1992). Abnormally high numbers of atretic oocytes have also been observed in fish undergoing acidinduced stress (McCormick et al. 1987). The incidence of oocyte atresia were only marginally higher in Mitchell Branch than in the reference sites (Table 5.4).

Two reproductive hormones, estradiol and testosterone, were measured in prespawning fish sampled from the study sites. The first of these two steroidal compounds, $17 \beta$-estradiol, has the critical function in female fish of regulating the production of yolk proteins by the liver for incorporation into vitellogenic oocytes. The primary role of testosterone in female fish is less clear, although it serves as a precursor in the production of $17 \beta$-estradiol and may also function in regulating spawning behavior (Greeley et al. 1988). The serum levels of one 
Table 5.4. Comparision of reproductive bioindicators in female redbreast sunfish, Lepomis auritus, collected from Mitchell Branch and several reference streams at the beginning of the 1993 reproductive season.

Asterisks identify values at the reference sites which differ significantly $(\alpha=0.05)$ from Mitchell Branch

\begin{tabular}{llccccccc}
\hline Site & Date & $\mathrm{n}$ & GSI $^{\circ}$ & $\begin{array}{l}\text { Atretic } \\
\text { oocytes }\end{array}$ & $\begin{array}{l}\text { Vitellogenic } \\
\text { oocytes }\end{array}$ & Fecundity $^{\mathrm{b}}$ & Testosterone $^{\mathrm{e}}$ & Estradiol $^{\circ}$ \\
\hline Mitchell Branch & $5 / 26 / 93$ & 16 & $17.0 \pm 0.4$ & $0.4 \pm 0.1$ & $113.0 \pm 3.3$ & $75.5 \pm 3.4$ & $4.91 \pm 10.06$ & $1.76 \pm 0.41$ \\
Hinds Creek & $6 / 8 / 93$ & 12 & $12.9 \pm 0.9^{*}$ & $0.2 \pm 0.2$ & $77.7 \pm 5.0^{*}$ & $47.5 \pm 3.4^{*}$ & $6.59 \pm 2.52$ & $4.13 \pm 0.71$ \\
Brushy Fork & $6 / 7 / 93$ & 16 & $9.9 \pm 0.6^{*}$ & $0.0 \pm 0.0^{*}$ & $63.6 \pm 3.9^{*}$ & $45.0 \pm 3.1^{*}$ & $8.00 \pm 1.65$ & $6.12 \pm 1.39^{*}$ \\
Paint Rock Creek & $5 / 27 / 93$ & 10 & $7.9 \pm 0.5^{*}$ & $0.3 \pm 0.1$ & $59.5 \pm 3.1^{*}$ & $39.0 \pm 2.8^{*}$ & $2.88 \pm 0.85$ & $2.63 \pm 0.40$ \\
\hline
\end{tabular}

GSI = gonadal-somatic index

- Oocytes or eggs per gram of body weight

' Steroid concentration in $\mathrm{ng}$ per $\mathrm{ml}$ of serum 
or both of these steroids have been shown to decrease in fish following laboratory or environmental exposure to a number of potential environmental pollutants, including PCBs (Sivarajah et al. 1978, Thomas 1990), aromatic hydrocarbons (Johnson et al. 1988), paper and pulp mill effluents (McMaster et al. 1991, Munkittrick et al. 1992), lead (Thomas 1990), cyanide (Ruby et al. 1993), organochlorine or organophosphorus pesticides (Singh and Singh 1987), and crude petroleum (Truscott et al. 1983). Plasma levels of both steroids tended to be lower at Mitchell Branch than the reference sites (Table 5.4), although only in the case of Brushy Fork and estradiol was there a significant difference between Mitchell Branch and any of the sites.

The integrated responses of the various reproductive indicators were examined by canonical discriminant analysis (Fig. 5.9). The overall reproductive condition of the redbreast sunfish population in Mitchell Branch was observed to differ significantly from the reproductive conditions of populations in each of the three reference sites, as shown both graphically (Fig. 5.9) and statistically (Table 5.5). Collectively, the results of both the integrative analysis and the individual reproductive responses, particularly the increased fecundity and abundance of vitellogenic oocytes in fish from Mitchell Branch, clearly demonstrate that, in the spring of 1993, redbreast sunfish in Mitchell Branch expended significantly more energy for reproduction than did the reference populations.

\subsubsection{Embryo-larval tests for developmental toxicity}

The successful propagation of fish populations requires that adults be capable of producing viable gametes and successfully completing the mating or spawning act and that offspring be able to develop and grow normally into subsequent reproductive cohorts. Beginning in the summer of 1993, water samples from several sites along Poplar Creek and two sites in Mitchell Branch were tested for their effects on fish developmental processes with a quarterly series of medaka embryo-larval tests (Table 5.6).

Embryos raised in control solutions had a suitably high survival rate during this series of toxicity tests (Table 5.6). Water samples from the headwaters of Mitchell Branch, upstream of any waste discharges from the K-25 Site, consistently yielded similarly benign results in the medaka embryo-larval tests. In contrast, water samples from lower Mitchell Branch (MIK 0.12) were nearly as consistent in their lethal effects on medaka embryos. In three out of the four tests conducted to date on water from these sites, embryo survival was significantly 


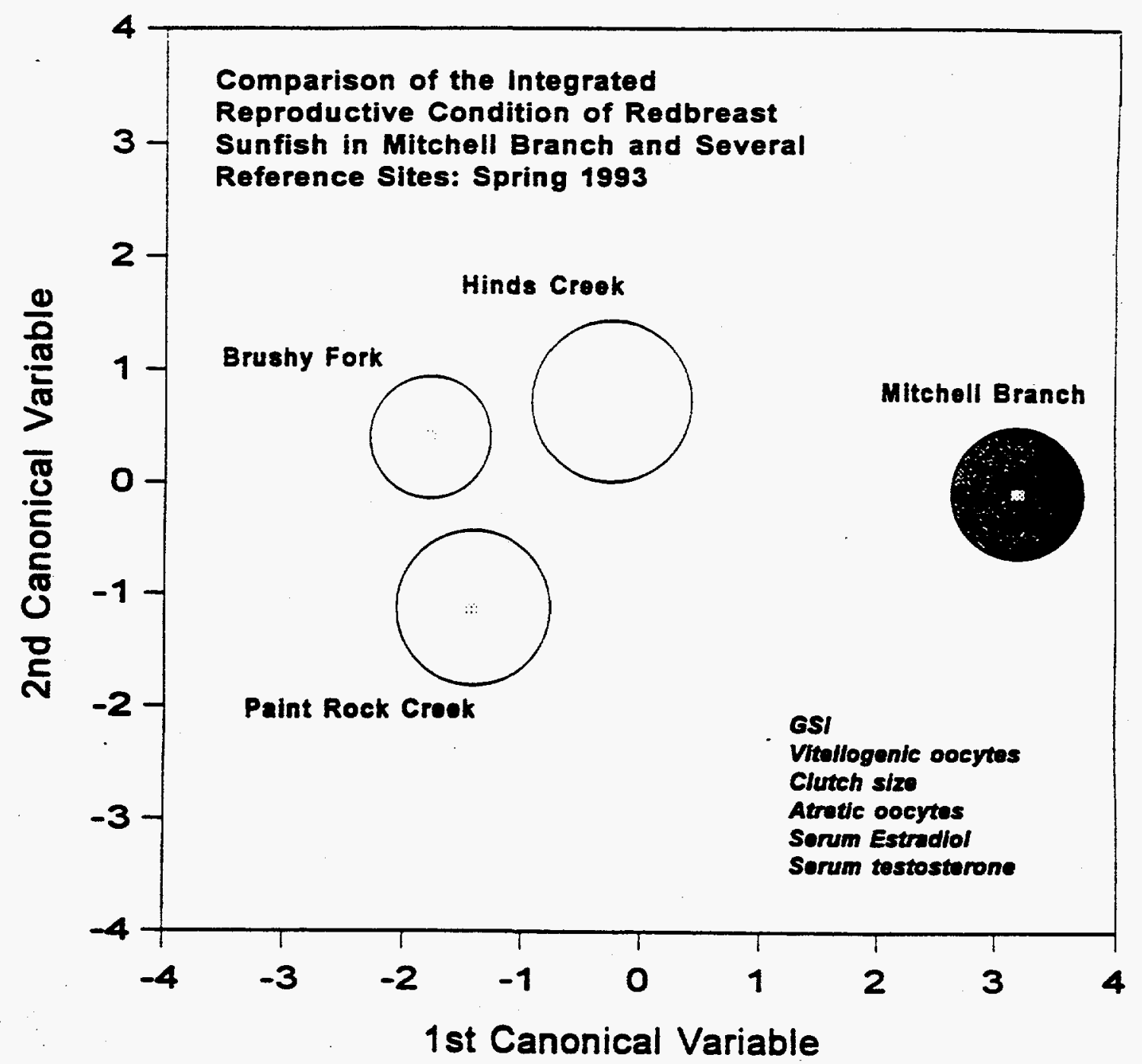

Fig. 5.9. Segregation of integrated reproductive responses of female redbreast sunfish collected in 1993 prior to the onset of the reproductive season. Circles represent site means and the reproductive approximate $95 \%$ confidence radii of that site-year means. Parameters contributing to the analysis are listed in the lower right portion of the figure. GSI = Gonadal-somatic index. 
Table 5.5. Mahalanobis' distances and associated probability values for site-to-site comparisions of the integrated reproductive condition of female redbreast sunfish sampled from Mitchell Branch and various reference sites at the beginning of the 1993 reproductive season

\begin{tabular}{lllll}
\hline Sites & Mitchell Branch & Hinds Creek & Brushy Fork & Paint Rock Creek \\
\hline Mitchell Branch & 0 & 13.05 & 24.97 & 22.39 \\
& $p<1.0000$ & $p<0.0001$ & $p<0.0001$ & $p<0.0001$ \\
& & & \\
Hinds Creek & 13.05 & 0 & 3.34 & 4.99 \\
& $p<0.0001$ & $p<1.000$ & $p<0.0290$ & $p<0.0080$ \\
Brushy Fork & 24.97 & 3.34 & 0 & 2.81 \\
& $p<0.0001$ & $p<0.0290$ & $p<1.000$ & $p<0.0461$ \\
Paint Rock Creek & 22.39 & 4.99 & 2.81 & 0 \\
& $p<0.0001$ & $p<0.0080$ & $p<0.0461$ & $p<1.000$ \\
\hline
\end{tabular}

Table 5.6. Results of quarterly medaka embryo-larval toxicity tests of ambient water samples from Mitchell Branch and Poplar Creek, 1993-1994

\begin{tabular}{lccccc}
\hline & & \multicolumn{5}{c}{ Survival (\%) } \\
\cline { 3 - 6 } Sample & Conc. (\%) & July 1993 & October 1993 & January 1994 & April 1994 \\
\hline Control 1 $\left(\mathrm{dH}_{2} \mathrm{O}\right)$ & 100 & 91 & 83 & 92 & 96 \\
Control 2 (ERM) & 100 & 86 & - & - & - \\
Control 3 (DMW) & 100 & - & - & 96 & 87 \\
& & & & & \\
MIK 1.43 & 100 & 96 & 100 & 100 & 100 \\
MIK 0.12 & 100 & $23^{*}$ & $9 *$ & 72 & $28^{*}$ \\
& & & & & \\
PCK 18.2 & 100 & $4^{*}$ & $40^{*}$ & 100 & 92 \\
PCK 8.2 & 100 & $0^{*}$ & $20^{*}$ & 92 & 92 \\
PCK 6.3 & 100 & $4^{*}$ & $8^{*}$ & 80 & 84 \\
PCK 4.7 & 100 & $9^{*}$ & $20^{*}$ & $63^{*}$ & 92 \\
PCK 1.6 & 100 & 76 & $12^{*}$ & $36^{*}$ & 84 \\
\hline
\end{tabular}

Note: $\mathrm{dH} 2 \mathrm{O}=$ distilled water, $\mathrm{ERM}=$ Medaka Embryo Rearing Medium, DMW $=$ degassed mineral water, $\mathrm{MIK}=$ Mitchell Branch kilometer and PCK $=$ Poplar Creek kilometer. Asterisks identify results that are significantly different from control $1(p=0.05)$ 
$(p<0.05)$ reduced as a result of exposure during development to water from this location. During the course of the fourth test, survival was also reduced, but not to the extent seen in other tests. These results clearly indicate that Mitchell Branch becomes toxic to the embryos of at least certain fish species during its passage through the K-25 Site.

The results of the medaka embryo-larval tests conducted on Poplar Creek are less consistent and more difficult to explain (Table 5.6). In the first test conducted for this project (in July 1993), embryo survival was extremely poor in water from all Poplar Creek sites, with the exception of PCK 1.6 near the confluence of Poplar Creek and the Clinch River. The extent to which activities at the K-25 Site contributed to the embryotoxic effects of water in lower Poplar Creek cannot be determined from this data, because water from the Poplar Creek reference site (PCK 18.2) located well upstream of any influences from either the K-25 Site or any other DOE facility proved in this test to be as or more toxic than water from sites closer to ORR. Potential upstream sources for toxic substances in the Poplar Creek system include wastes from a sewage treatment plant in Oliver Springs, Tennessee (which was undergoing major renovation and construction activities during the time period of these investigations), agricultural activities, domestic wastes, and urban runoff.

Similar results were obtained from a medaka embryo-larval test conducted in October 1993 (Table 5.6). In this instance, embryo survival was somewhat better at the instream reference site than during the previous July test and was further reduced at the study sites adjacent to or downstream of ORR. By January there was $100 \%$ survival of embryos raised in water from the upstream reference site, with significant toxicity developing only at the furthermost downstream study sites. The results of the latest medaka embryo-larval test, conducted in April 1994, indicate a near total absence of a toxic effect at any of the lower Poplar Creek study sites. Potential explanations for the highly variable results of medaka embryo-larval tests on water from Poplar Creek include intermittent toxic inputs from upstream sources such as farms, seasonal and weather-related climatic effects on water quality in the stream, and the complicating effects of irregular water flow into and out of Poplar Creek due to TVA practices for managing water levels in their reservoirs (including Watts Bar Lake) and generating electricity at nearby Melton Hill Dam. 


\subsubsection{Conclusions}

Redbreast sunfish in Mitchell Branch appear to be reproductively competent, producing an over-abundance of apparently viable gametes and having a very high relative fecundity. However, it is this abnormally high expenditure of resources for gamete production that distinguishes the reproduction characteristics of the sunfish population in Mitchell Branch from reference populations (Fig. 5.9). The enhancement of gamete production in Mitchell Branch sunfish could be a stress response to xenobiotics in the diet or water, a result of nutrient enrichment in the stream, the consequence of altered temperature regimes, or the result of lessened competition from the absence of pollutant sensitive fish species. Most likely, a combination of several factors shares responsibility for the observed deviations from the apparent reproductive norm for this species.

The current results of an ongoing quarterly series of medaka embryo-larval tests of water from Mitchell Branch and Poplar Creek clearly indicate that lower Mitchell Branch is often very toxic to medaka embryos. This observation may well explain, at least in part, why fish species known to be relatively sensitive to pollutants have so far failed to establish breeding populations in the lower reaches of this stream. The results of embryo-larval tests conducted on water from Poplar Creek have been more variable and suggest additional sources of toxic inputs into the creek well upstream of the ORR.

\subsubsection{Future Studies}

Redbreast sunfish will continue to be sampled annually from lower Mitchell Branch to monitor the relative reproductive health of this population. Future studies along these lines will expand to include a closer analysis of the reproductive condition of male sunfish in this location and possibly include a reproductive examination of other fish species in the stream.

As a consequence of consistent findings of significant embryotoxic effects in water samples from the lower reaches of Mitchell Branch, medaka studies will be expanded to include additional reaches of the stream closer to the potential sources of the toxic effect. Similar experiments will also be conducted intermittently with the embryos of other fish species to address questions concerning the ecological relevance and applicability to other species of the medaka embryo-larval tests. In addition, studies are planned to identify the substance(s) in the stream water that are responsible for the observed embryotoxic effect. 


\section{INSTREAM MONITORING (TASK 4) \\ J.G. Smith and E. M. Schilling}

The objectives of the instream ecological monitoring task are to (1) characterize spatial and temporal patterns in the distribution and abundance of the benthic macroinvertebrate and fish populations in Mitchell Branch and (2) document the effects of new pollution abatement facilities on community structure and function. This task consists of two components: (1) benthic macroinvertebrate community studies (Subtask 4a) and (2) fish population studies (Subtask 4b); results to date for these studies are presented in Sects. 6.1 and 6.2 respectively.

\subsection{BENTHIC MACROINVERTEBRATES ( $J$. G. Smith)}

\subsubsection{Introduction}

During the initial 18 months (August 1986-January 1988) of the K-25 Site BMAP, results of the benthic macroinvertebrate community studies showed that, relative to the upstream reference site (MIK 1.43), the portion of Mitchell Branch immediately adjacent to the main K-25 Site was significantly impacted (Smith 1993; Smith 1994). Greatest impact was evident at the site (MIK 0.71) just downstream of SD 170 where several major taxonomic groups of invertebrates were conspicuously absent [e.g., Ephemeroptera, Plecoptera, Trichoptera (EPT)]. Some improvement in the condition of the macroinvertebrate community was evident at the two sites located downstream of MIK 0.71 (sites MIK 0.54 and MIK 0.45 located below SD 180 and SD 190 respectively), but major taxonomic groups were absent from these sites as well, thus, indicating these two sites were also impacted.

Studies of the benthic macroinvertebrate community continued after January 1988 with the specific objectives of (1) spatially evaluating the benthic macroinvertebrate community of Mitchell Branch for evidence of impacts associated with operations at the K-25 Site, (2) continuing efforts to help identify causal factors responsible for any observed adverse impacts and (3) documenting the response of the macroinvertebrate community to any new pollution abatement activities or remedial actions. This report summarizes the results obtained through April 1993. 


\subsubsection{Materials and Methods}

The monthly sampling regime initiated in August 1986 continued through July 1988; after July 1988, the sampling frequency was reduced to once per quarter. Benthic macroinvertebrate samples were collected from six sites in Mitchell Branch through July 1992 (Fig. 2.1); then, beginning in October 1992, two sites were dropped (MIK 0.54 and MIK 0.86). Because of the close proximity of MIK 0.86 to MIK 0.78 and of MIK 0.54 to MIK 0.45 , as well as the relative similarities of the benthic communities at these site-pairs, it was felt that any major changes in the invertebrate community should be detectable at the retained sites. Dropping MIK 0.54 is further justified because the effluent from SD 180 , which is just upstream of MIK 0.54, is toxic less frequently than the effluent from SD 190, which is just upstream of MIK 0.45 (Sect. 3.2). With continued toxicity testing of effluents from SD 180 and SD 190, the retention of a benthic macroinvertebrate monitoring site at MIK 0.45 , which is downstream of both storm drains, will allow the detection of major changes in Mitchell Branch that may be associated with discharges from either storm drain. Likewise, dropping MIK 0.86 is supported by the fact that there are no major effluent discharges upstream of MIK 0.78; thus, the existence of a single site between MIK 1.43 and SD 170 should allow the detention of any major changes should they occur in this portion of the stream. Also, although samples were collected monthly during the first 2 years of the BMAP and quarterly after the second year, only the samples collected during the spring (April) and fall (October) sampling periods after January 1988 were processed. The samples collected during the other sampling periods were archived and will be processed only if further resolution of the data is needed for future reports. Following this plan of action ensures the sample processing remains up to date without compromising the results from this task.

During each sampling period, three random benthic macroinvertebrate samples were collected from a riffle at each site with a Surber stream bottom sampler $\left(0.09 \mathrm{~m}^{2}\right.$ or $1 \mathrm{ft}^{2}$; $363-\mu \mathrm{m}$-mesh net). Samples were placed into pre-labeled, glass jars and preserved in $80 \%$ ethanol; the ethanol was replaced with fresh ethanol within 1 week. Additional details of the field and associated quality assurance (QA) procedures followed in the collection and maintenance of these samples are given in Smith (1992).

Supplemental data on water quality and physical characteristics of each site were recorded at the time of sampling. Temperature, conductivity, dissolved oxygen, and $\mathrm{pH}$ were measured with an Horiba Model U-7 Water Quality Checker. Water depth, location within the riffle 
area (distance from permanent headstakes on the stream bank), visual determination of relative current velocity (very slow, slow, moderate, or fast), and substrate type (visual determination), based on a modified Wentworth particle size scale (Loar et al. 1985), were recorded for each sample. All measurements/data for water quality and stream characteristics were obtained in accordance with established QA procedures (Smith 1992). The supplemental data were used only if needed for observational support.

Benthos samples were washed in the laboratory after being placed into a U. S. Standard No. 60-mesh (250- $\mu \mathrm{m}$-mesh) sieve. Small aliquots of the sample were removed from the sieve, placed into a white tray containing water, and then the organisms were removed from the sample debris with forceps. This was repeated until the entire sample was sorted. Finally, the removed organisms were identified to the lowest practical taxon and enumerated. Further details of the laboratory procedures followed in order to process benthos samples may be found in Wojtowicz and Smith (1992).

Data were managed and analyzed on computer primarily with SAS software and procedures (SAS 1985a; SAS 1985b). Statistical analysis included both descriptive and parametric statistical techniques. Parametric procedures included ANOVA models on three responses: density (total number of organisms $/ 0.1 \mathrm{~m}^{2}$ ), total richness (total number of taxa/sample) and the total combined number of the EPT taxa (total number of EPT taxa/sample or EPT richness). These responses (density and total richness) were selected because they are a good, general indicator of the overall condition of a macroinvertebrate community and a more specific indication (EPT richness) of the condition of a macroinvertebrate community based on taxa that are generally intolerant of most types of pollution (Lenat 1988). Prior to performing the ANOVAs, observed values for each response were appropriately transformed [i.e., $\log _{10}(X+1)$ for density values, and the square root of $\mathrm{X}$ for total and EPT richness values, where $X=$ the individual observed values for density, taxonomic richness, and EPT richness; Elliott 1977]. Statistical analysis with the ANOVAs ineluded two approaches that provided a step-wise evaluation of the data to try to detect temporal changes at sites previously identified as impacted (relative to MIK 1.43, the reference site), which may have been indicative of eithe improvements or further degradation. For each approach, a significance level of $p<0.05$ was used. Although monthly data were available from the first 18 months of the BMAP, only the April (spring) and October (fall) data were used from this time period in order to provide a data set that was uniform with the data 
available after this time period. Additionally, because MIK 0.54 and MIK 0.86 were limited to only 6 years of data (October 1986 through April 1992), all analyses that included these two sites were limited to data from the first 6 years only.

The first approach was a nested ANOVA model that analyzed the data for site differences (fixed effect) among the sampling years (fixed effect) with seasonal (i.e., April = spring and October $=$ fall; random effect) differences nested within sampling year. This approach provided (1) an overall evaluation of the differences in mean responses across the sampled sites and sampling years, (2) an evaluation of the interaction between the site and sampling year effects, (3) an overall evaluation of the variation in the response from the spring to fall sampling period within a sampling year, and (4) a test of whether the variation in (3) changed significantly from site to site.

For the second approach, a simple linear regression was used to estimate site-specific linear trends for each response over the study period on season-specific data. For this approach, the slopes of the regression lines for all sites were compared by season for parallelism with an ANOVA. This allowed the data for the potentially impacted sites to be evaluated, relative to MIK 1.43 , with respect to linear trends within each season that may have been indicative of persistent improvement (i.e., increasing values through time) or degradation (i.e., decreasing values through time). In addition, because the variability around the regression lines was not the same for all sites (an assumption of this technique), which reduced the ability to detect significant trends, the analysis was repeated for all possible pairwise comparisons of each downstream site with MIK 1.43 .

\subsubsection{Results}

\subsubsection{Taxonomic composition}

A checklist of the benthic macroinvertebrates collected from each site on Mitchell Branch is presented in Appendix D, Table D.1. The collection of macroinvertebrates during only two seasons within each year over a 7-year period does not allow the compilation of a complete list of taxa from each site because the occurrence of many other taxa is limited to seasons of the year that were not sampled. However, the presence or absence of common taxa or major taxonomic groups from this limited number of sampling periods does provide useful information for assessing the overall well-being of the benthic macroinvertebrate community. Most major groups of macroinvertebrates typical of streams (e.g., Hynes 1970) were 
represented in Mitchell Branch by one or several taxa during the 7 years of study, including the Oligochaeta (aquatic worms), Amphipoda (sideswimmers/scuds), Decapoda (crayfish), Hydracarina (mites), Bivalvia (mussels/clams), Ephemeroptera (mayflies), Plecoptera (stoneflies), Trichoptera (caddisflies), Odonata (dragonflies/damselflies), Megaloptera (dobsonfiles/fishflies), Coleoptera (beetles), and Diptera (true flies). Not only were spatial trends obvious in the occurrences of taxa within each of these major groups, temporal trends were obvious as well. Particularly notable was the absence or sporadic appearance of many of the taxa within certain groups at some sites downstream of MIK 1.43, especially from within groups such as the EPT (mayflies, stoneflies and caddisflies respectively). No ephemeropterans were collected at the three sites downstream of MIK 0.78 prior to the fifth year of sampling (i.e., October 1990), and the number of epemeropteran taxa present at MIK 0.78 and MIK 0.86 was considerably limited prior to the third year (i.e., October 1988). Plecopterans were not collected downstream of MIK 0.78 prior to the fifth year, and none were collected from MIK 0.54 during the entire study. At MIK 0.78 and MIK 0.86, most plecopteran taxa did not appear in samples until the second or third years. The few trichopterans sporadically collected from the three sites downstream of MIK 0.78 did not appear in the samples until after the third year, and most of the trichoptera taxa collected from MIK 0.78 and MIK 0.86 were not collected until the fourth year.

\subsubsection{Abundance}

Density. Total community density changed considerably through time at all sites (Fig. 6.1). Density at MIK 1.43 changed least during the study, with the highest (April 1989) and lowest (October 1986) values differing by a factor of $7.2 \times$; a distinct pattern of seasonal changes was not obvious at this site. In contrast, densities at the five other sites exhibited much greater fluctuations during the study. The magnitude of changes occurring during the study at MIK 0.45 and MIK 0.54 were similar, where the highest (April 1990, both sites) and lowest (October 1990, both sites) density values differed by a factor of approximately $85 \times$. Seasonal changes between these two sites, however, were different. At MIK 0.54 after April 1988 , spring highs were generally followed by fall lows, while at MIK 0.45 no consistent seasonal pattern was evident. The magnitude of changes that occurred at MIKs 0.78 and 0.86 were also similar, with the highest (April 1989, both sites) and lowest (October 1986, both sites) density values differing by a factor of about $250 \times$. These two sites showed distinct 

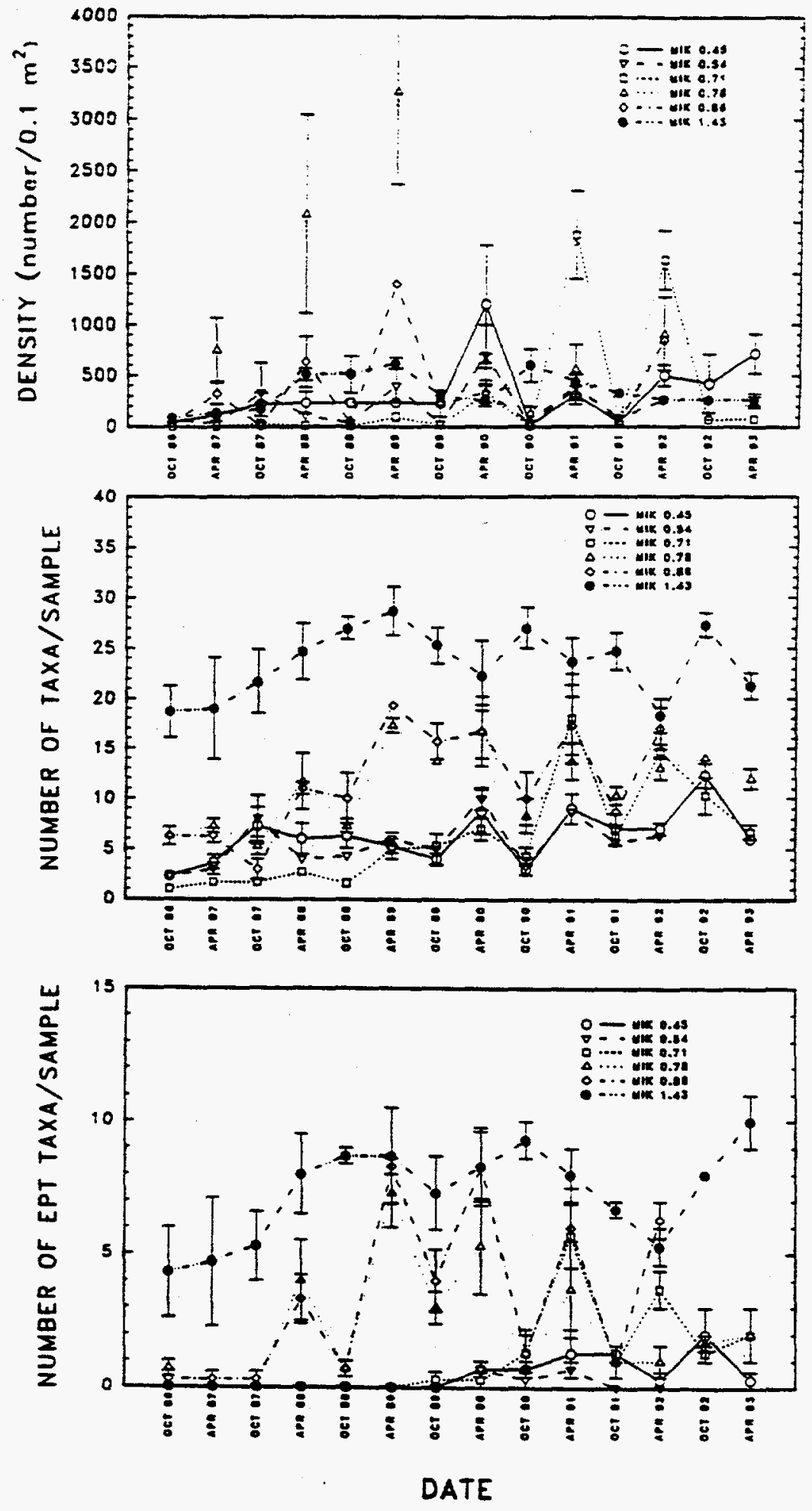

Fig. 6.1. Mean total density, mean total richness, and mean richness of the Ephemeroptera, Plecoptera, and Trichoptera (EPT richness) of the benthic macroinvertebrate communities in Mitchell Branch, October 1986-April 1993. Vertical bars represent \pm SE. MIK $=$ Mitchell Branch kilometer. 
seasonal patterns in density, with spring highs followed by fall lows. The greatest change occurred at MIK 0.71 where the lowest (October 1986) and highest (April 1991) density values differed by a factor of $1338 \times$. Density values at MIK 0.71 were generally highest during the spring sampling periods, although this pattern did not consistently hold.

Considerable spatial differences in mean density were also evident during each sampling period (Fig. 6.1). The lowest densities were most frequently observed at MIK 0.71 ( 9 of 14 sampling periods); however, densities were also higher at MIK 0.71 than at ather sites during 2 of the sampling periods (April 1991 and April 1992). The greatest difference (301.6x) among the sites between the highest (MIK 0.78) and lowest (MIK 0.71) values occurred in April 1987, and the least difference among the sites occurred in April 1990 when the factor of difference between the lowest (MIK 1.43) and highest (MIK 0.45) values was only $4.7 \times$.

Seasonal changes among two or more of the sites were significantly different across 2 or more years whether the data were analyzed for all six sites from the first 6 years only or only 4 sites from all 7 years (Table E.1, Appendix E). The regression analyses further demonstrated that the long term trends of change occurring between two or more sites were different in both seasons (Table E.2). Pairwise comparisons of regression slopes indicated that only the patterns of change that occurred at MIK 0.54 and MIK 0.71 were significantly different from the pattern of change at MIK 1.43 (Table E.2; Figs. F.1 and F.2). The regression lines for MIK 0.54 and MIK 1.43 exhibited opposite trends in each season (Fig. F.1), while the regression lines for MIK 0.71 and MIK 1.43 exhibited opposite trends in the spring only (Fig. F.2).

Relative abundance. In general, the macroinvertebrate community at each site was composed predominantly of chironomids, oligochaetes, ephemeropterans, plecopterans, and/or trichopterans (Fig. 6.2). The chironomids were consistently one of the most abundant groups at all sites. Although considerable temporal fluctuations occurred in their relative abundances, they generally accounted for $20 \%$ or more of the total density at most sites during most sampling periods. A slight yet notable deviation from this trend occurred at MIK 0.71 where chironomids were absent from samples collected during two of the first three sampling periods. After the October 1988 sampling period, they accounted for at least $30 \%$ of the total density during the remainder of the study at MIK 0.71 . 
PEncent conpostion
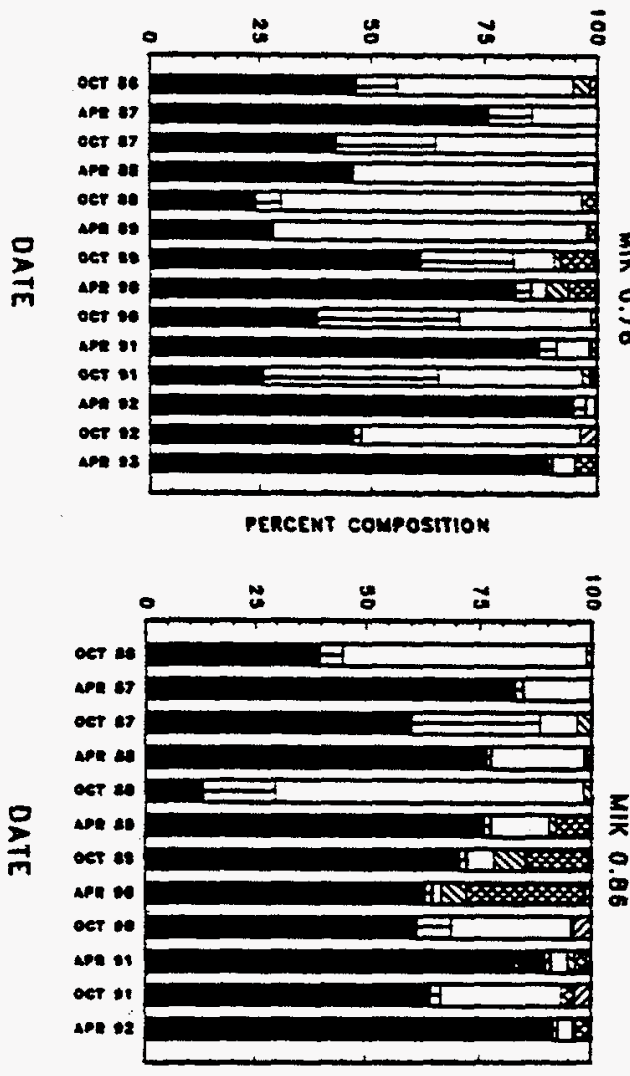

PEACENT COMPOSITION

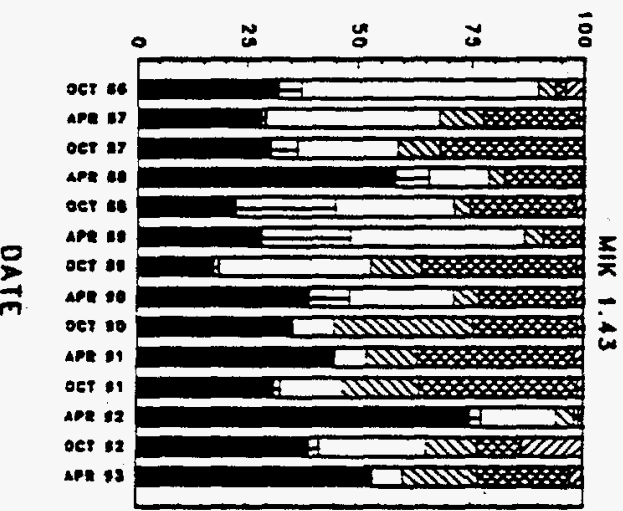

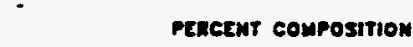
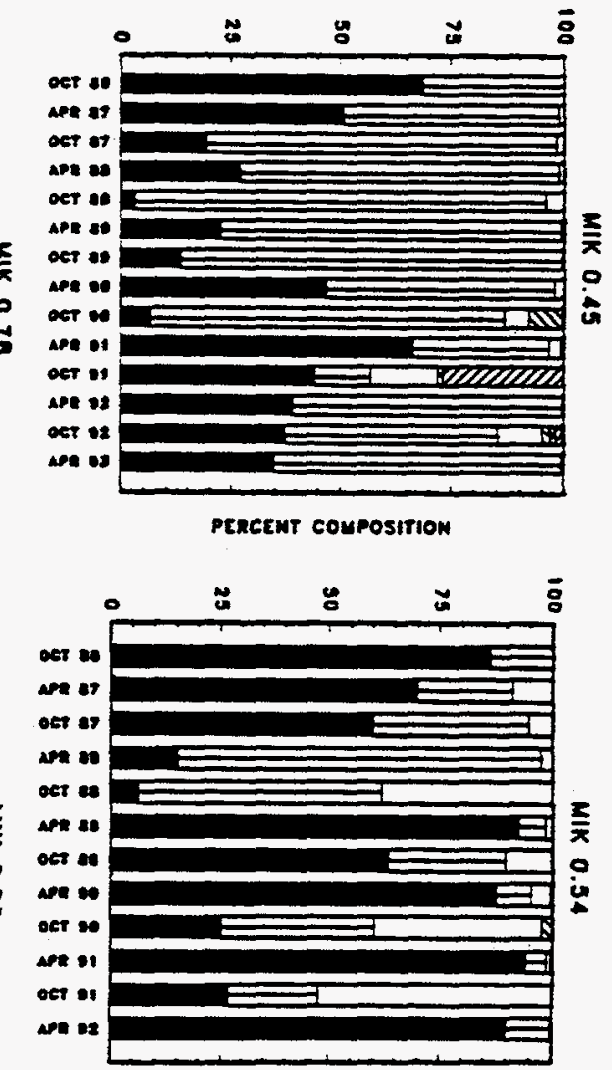

PERCENT COMPOSITIOM

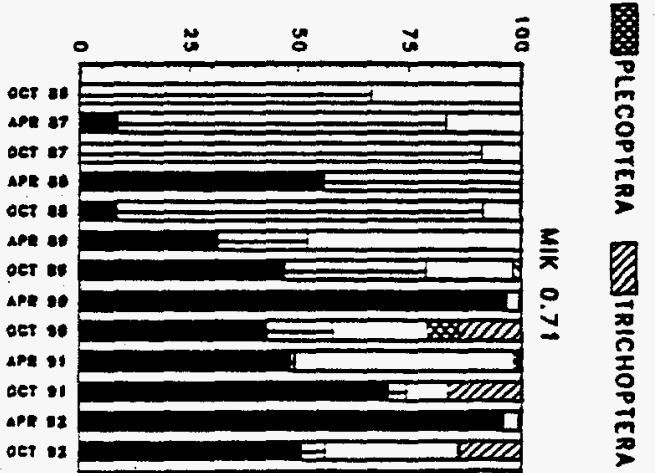


The Oligochaeta were most prominent downstream of MIK 0.78 , particularly at MIK 0.45 where they accounted for over $30 \%$ of the total density during almost every sampling period (Fig. 6.2). The relative abundances of the oligochaetes at MIK 0.54 were generally much less than at MIK 0.45 but they still usually accounted for more than $10 \%$ of the total density. At MIK 0.71 the oligochaetes constituted over $45 \%$ of the total density during the first five sampling periods; but after October 1988, they generally made up much less than $25 \%$ of the total density. At MIKs $0.78,0.86$, and 1.43 , the relative abundance of the oligochaetes was highly variable, but they usually accounted for $<10 \%$ of the total density.

Except at MIK 1.43, collections of Ephemeroptera, Plecoptera, and Trichoptera were sporadic, particularly downstream of MIK 0.78 where their individual or combined relative abundances rarely exceeded $1 \%$ of the total density (Fig. 6.2). Even though they were collected more frequently at MIK 0.78 and MIK 0.86 than at the three downstream most sites, the individual relative abundances of the ephemeropterans, plecopterans, and trichopterans usually did not exceed $5 \%$ of the total density, and their combined relative abundances usually did not exceed $10 \%$. In contrast, the relative abundances of the Ephemeroptera and Plecoptera at MIK 1.43 usually exceeded $5 \%$ and often exceeded 20\%. Furthermore, the combined relative abundance of the ephemeropterans, plecopterans, and trichopterans usually exceeded $30 \%$ of the total density at MIK 1.43 .

\subsubsection{Richness}

Total richness. Total richness (i.e., total number of taxa/sample), like density, changed considerably through time at each site, although the magnitude of change was much less (Fig. 6.1). Also as for density, the greatest and least change in total richness occurred during the study at MIK 0.71 and MIK 1.43 respectively; the magnitude of difference between the highest (April 1991) and lowest (October 1986) values at MIK 0.71 was 18.0x, while the magnitude of difference between the highest (April 1989) and lowest (April 1992) values at MIK 1.43 was only $1.5 \times$. The magnitude of differences between the highest and lowest total richness values during the study at the other four sites ranged from $2.7 \times$ at MIK 0.78 to $6.4 \times$ at MIK 0.86 . Only MIK 0.78 and MIK 0.86 exhibited consistent and distinct seasonal patterns of change, with spring increases followed by declines in the fall.

Total richness remained distinctly higher at MIK 1.43 than at all other sites during all sampling periods (Fig. 6.1). The greatest difference between the highest and lowest values 
occurred in October 1986 when total richness at MIK 1.43 was $18.7 \times$ higher than at MIK 0.71. The least difference among the sites occurred in April 1991 when the difference between the highest (MIK 1.43) and lowest (MIK 0.54) values was only 2.7×. A notable trend occurred in spatial differences after October 1988. Prior to April 1989, the difference between the highest and lowest values was never less than a factor of $9 \times$, but after October 1988, the difference between the highest and lowest values never exceeded $9 \times$ and exceeded $5 \times$ only three times. Similarly, prior to April 1989 total richness at MIK 1.43 was more than $2 \times$ higher than at all other sites in all sampling periods, but after October 1988, the difference between MIK 1.43 and the sites with the next highest values exceeded $2 \times$ during only two sampling periods.

As was seen for density, the pattern of seasonal change in total richness exhibited among two or more sites was not the same across all years whether the data were analyzed for all six sites for the first 6 years only, or for only four sites for all 7 years (Table E.1). The regression analysis indicated that total richness changed differently at two or more sites during the spring sampling periods in the first 6 years and during all 7 years (Table E.2). In contrast, changes in total richness across all sites during the fall sampling periods were not different in the first 6 years, but over all 7 years a significant difference existed. Changes at MIK 0.71 were significantly different from those at MIK 1.43 over the entire 7-year study period in both the spring and fall, while those at MIK 0.45 or MIK 0.78 were not (Table E.2). Changes at MIK 0.54 and MIK 0.86 were significantly different from those at MIK 1.43 during the spring only; during this season, their regression lines indicated that richness increased, while at MIK 1.43 richness exhibited a slight decline (Table E.2; Fig. F.2).

EPT richness. The amount of temporal change exhibited in the combined EPT richness of the in Mitchell Branch during the study was substantial, particularly at the sites from MIK 0.86 downstream to MIK 0.45 (Fig. 6.1). EPT taxa were not collected from MIK 0.78 during two sampling periods (April 1987 and October 1987); from MIK 0.71 during all sampling periods from October 1986 through April 1989; from MIK 0.45 during all sampling periods from October 1986 through October 1989; and from MIK 0.54 during all sampling periods except April and October 1987. EPT taxa were collected in all sampling periods from MIK 0.86 and MIK 1.43; however, mean EPT richness at MIK 0.86 was much less than 1.0 during the first three sampling periods and frequently $<2.0$ during the remainder of the study. 
Except in April 1992, EPT richness was higher at MIK 1.43 than at all other sites throughout the study (Fig. 6.1). Following the October 1987 sampling period, the amount of difference between MIK 1.43 and MIK 0.86 and MIK 0.78 followed a strong seasonal trend, with the largest differences generally occurring during the October sampling periods. At the remaining three sites, even after EPT taxa began to consistently occur, large differences (at least $4 \times$ ) generally persisted between them and MIK 1.43 .

As was seen for density and total richness, the pattern of seasonal change in EPT richness exhibited among two or more sites was not the same across all years whether the data were analyzed for the first 6 years only, or only four sites were analyzed for all 7 years (Table E.1). Analyses of the regression slopes indicated that no statistically significant differences existed in the pattern of change across all sites during the fall, whether evaluated for six sites during the first 6 years only, or for only four sites for all 7 years (Table E.2; Figs F.1 and F.2). Except for a marginally significant difference between MIK 1.43 and MIK 0.45 , all pairwise comparisons supported the overall site analyses (Table E.2). These results suggest that none of the changes that occurred in EPT richness at MIK 1.43 differed markedly from those at the other five sites. During the spring however, analyses of the slopes across all sites indicated that significant differences existed (Table E.2; Figs. F.1 and F.2). Pairwise comparisons of the spring data indicated that the only site that changed differently from MIK 1.43 was MIK 0.71 (Table F.2; Fig. F.1). Although the regression lines suggest that there was an overall increase in EPT richness at both sites during the spring, the increase appeared to be more substantial at MIK 0.71 over the course of the study.

\subsubsection{Discussion}

The benthic macroinvertebrate community of Mitchell Branch within the main boundary of the K-25 Site continued to indicate the presence of degraded water quality through April 1993. Relative to the reference site, both total and EPT richness were clearly and persistently depressed at all sites from MIK 0.86 downstream to MIK 0.45 . Furthermore, the macroinvertebrate community at these sites was predominantly composed of chironomids and/or oligochaetes; and the relative abundances of the Ephemeroptera and Plecoptera, and to a lessor extent the Trichoptera, were clearly depressed, a pattern often associated with streams having degraded water quality (e.g., Hynes 1960; Wiederholm 1984). 
As observed during the first 18 months of the K-25 BMAP (Smith 1993, 1994), the macroinvertebrate community of Mitchell Branch appeared to be most severely impacted at the three sites downstream of MIK 0.78. This was particularly notable prior to the April 1990 sampling period when taxa within the Ephemeroptera, Plecoptera, and Trichoptera were virtually absent from these three sites. After October 1989, the differences in the invertebrate community among the five sites downstream of MIK 1.43 became less distinct, especially at MIKs $0.71,0.78$, and 0.86 .

In addition to evaluating the condition of the macroinvertebrate community in Mitchell Branch spatially for evidence of area-specific impacts, the community at the impacted sites was also evaluated for evidence of temporal changes that might indicate recovery associated with improvements in water quality. The reference site was characterized by a relatively stable and diverse macroinvertebrate community that exhibited small fluctuations in density, total richness, and EPT richness between sampling periods as well as over the entire study, a characteristic of other reference sites on the DOE ORR as well (J. G. Smith, ESD/ORNL, unpublished data). Thus, although changes did occur at MIK 1.43 during the study, they were within a normal range.

In contrast, the impacted sites were characterized by substantial fluctuations in density, total richness, and EPT richness between most sampling periods and over the course of the study; this pattern has also been observed at other impacted stream sites on the ORR (J. G. Smith, ESD/ORNL, unpublished data). The most substantial change was observed at MIK 0.71, where, with the exception of EPT richness in the fall sampling periods, changes in density, total richness, and EPT richness were significantly different from those at MIK 1.43. Substantial and persistent increases in density, total richness, and EPT richness occurred at this site, particularly between October 1988 and October 1989, although total and EPT richness remained considerably depressed relative to MIK 1.43 . Thus, although some recovery appeared to have occurred at this site, impacts were still evident.

- At the other four sites as at MIK 0.71 , the extent of fluctuations in density between sampling periods was substantial, but only the changes at MIK 0.54 were statistically significant from those at MIK 1.43. However, the existence of opposite trends of change at MIK 0.54 over the spring (i.e., density increased) and fall (i.e., density decreased) sampling periods, in addition to the large fluctuations between sampling periods, suggests that no persistent and marked changes occurred in density at this site during the study. Similarly, the 
absence of trends of change at the other three sites that were significantly different from those of MIK 1.43, as well as the large fluctuations between sampling periods, suggests that densities at these three sites made no marked and persistent changes either.

Even though the only significant trends of change exhibited in total richness were at MIK 0.54 and MIK 0.86 vs MIK 1.43 during the spring, and changes in EPT richness were at MIK 0.45 vs MIK 1.43 during the fall; MIK 0.78 exhibited persistent and substantial changes in these two parameters as well. Most changes were evident in total richness by April 1988 or April 1989 and in EPT richness by October 1989. The most notable changes among these four sites occurred in EPT richness at MIKs 0.54 and 0.45. Prior to October 1989, EPT taxa were virtually absent from these two sites; after this period these taxa were usually represented by at least a few individuals during the remaining sampling periods, although their densities remained low. These changes suggest that some recovery occurred at all four sites, with the greatest amount of recovery occurring at MIKs 0.45 and 0.54 . However, as at MIK 0.71 , persistently low values for total and EPT richness along with continued low relative abundances of the generally pollution intolerant EPT taxa (e.g., Lenat 1988), suggests that impact was continuing at these sites.

The period of greatest change observed at the three sites downstream of MIK 0.78 coincided closely with an improvement in water quality that was demonstrated by ambient toxicity tests after 1988 (Kszos 1994). A delayed response in the invertebrate community following the apparent improvements in water quality in Mitchell Branch would be expected, because the rate of recolonization of a depauperate community would depend primarily upon drift of organisms from unimpacted or lesser impacted areas further upstream (Williams and Hynes 1976, 1977).

Because no major operational changes occurred at the K-25 Site prior to the end of 1988 that would have affected any site upstream of MIK 0.54 , and because some recovery appeared to occur at MIKs 0.78 and 0.86 after this period, the most likely explanation for the apparent improvement in lower Mitchell Branch after 1988 would be that of increased flow and dilution in the stream as a result of increased rainfall (Table 2.1; Hinzman and Loar 1994). The lack of a more significant response at MIKs 0.54 and 0.45 may be due to one or more of the following factors. (1) Prior to mid-1988, the invertebrate community at MIK 0.71 was considerably more degraded than at either MIK 0.54 or MIK 0.45 (Smith 1993, Smith 1994). Equal improvements in water quality would allow some recovery to occur at all affected sites, 
but since greater degradation originally existed at MIK 0.71 , the magnitude of recovery would be greater at this site. (2) Impacts as a result of discharges from SDs 180 and 190 may have suppressed recovery at MIKs 0.45 and 0.54 . (3) Habitat (i.e., substrate for attachment) at MIKs 0.45 and 0.54 was less suitable than at MIK 0.71 . The substrate at MIK 0.71 was generally composed of a mixture of gravel, sand, and silt with some rubble, while the substrate at MIKs 0.45 and 0.54 was generally composed of a mixture of small gravel, sand, and silt (J. G. Smith, ESD/ORNL, personal observation). In general, a mixture of rubble, gravel, and sand serves as a more suitable substrate for a greater variety of invertebrates, while small gravel, sand, and silt are preferred more by oligochaetes and some chironomids (Hynes 1970). This may partially explain the predominance of oligochaetes and chironomids at MIKs 0.45 and 0.54 , but excessive amounts of organic matter may favor these taxa as well (e.g., Hynes 1960).

Several potential factors contributing to the degraded macroinvertebrate community downstream of MIK 1.43 were previously identified and discussed by Smith (1994). These will likely continue to be important factors: siltation/sedimentation (J. G. Smith, ESD/ORNL, personal observation), elevated temperatures (Section 2.2.3), and the presence of at least periodically toxic conditions (Kszos 1993, 1994; Section 3), as suggested by the frequently low density values at some sites, particularly during the fall. The presence of periodically toxic conditions (or the episodic release of toxicants) is also suggested by the predominance of taxa (e.g., Chirononidae, Oligochaeta) that have short generation times; are capable of producing several generations each year; and/or always have a reproducing population present, thus increasing the probability that a resistent or unaffected stage will be present during a toxic excursion. Potential toxicants included chlorine (downstream of MIK 0.78) and possibly one or more metals or organic compounds. Flows were augmented from effluent discharges and flow regimes were altered by effluent discharges and changes in surface water runoff due to the lack of riparian vegetation in the vicinity of the stream. In addition to altering the flow regime, the lack of riparian vegetation also contributes to alterations of the stream's thermal regime by greater solar heating. The presence of enriched conditions was suggested by the periodically high macroinvertebrate densities at most of the impacted sites. 


\subsubsection{Summary and Conclusions/Recommendations}

Further studies of the benthic macroinvertebrate community after January 1988 indicated that the water quality of Mitchell Branch within the main K-25 Site boundary continued to be significantly degraded. However, some recovery in the macroinvertebrate community was evident at all impacted sites, most notably after 1988, indicating that some improvement has occurred in water quality. Recovery was greatest at MIK 0.71 , the site previously identified as the most severely degraded. Because recovery began prior to any significant operational changes at the K-25 Site and soon after the end of a drought (i.e., after the end of 1988), the improvements observed in the macroinvertebrate community may be caused by increased dilution of toxicants from associated increased instream flows and an increase in minimal flows, both of which are associated with the increase in rainfall. Continued impacts were most likely associated with operations of the K-25 Site that include a combination of factors such as siltation/sedimentation, elevated temperatures, the presence of at least periodically toxic conditions, altered stream flow and thermal regimes, and nutrient enrichment.

As a means of potentially increasing the amount and rate of recovery of the benthic macroinvertebrate community in Mitchell Branch, it is recommended that the riparian zone be expanded as much as feasible. It is also recommended that the strategic placement of rubble in the stream be considered as a means of habitat improvement and stability downstream of SD 170.

\subsubsection{Future Studies}

Monitoring of the benthic macroinvertebrate community in Mitchell Branch will continue as described in the BMAP Plan for the K-25 Site (Kszos et al. 1993). This will include the quarterly collection of samples from only four sites (MIKs $0.45,0.71,0.78$, and 1.43). Only the samples collected during the spring and fall sampling periods will be processed, while those collected during the summer and winter will be stored and processed only if necessary (Kszos et al. 1993). In addition to the use of MIK 1.43 as a reference site, other appropriate reference sites used for other biological monitoring programs on the ORR will also be incorporated into future data analyses. This will provide a more accurate assessment of the expected range of reference conditions in the Oak Ridge area.

Because similar perturbations affect Mitchell Branch and streams near ORNL and the Y-12 Plant, studies will be conducted over the next 5 years in conjunction with these other 
BMAPs to try to more accurately identify the causal factors associated with the degraded biotic communities in these streams. These studies may include but not necessarily be limited to a determination of the importance of elevated temperatures and excessive sedimentation to macroinvertebrates.

\subsection{FISH COMMUNITY ASSESSMENT (E. M. Schilling)}

\subsubsection{Introduction}

Fish population and community studies can also be used to assess the ecological effects of changes in water quality and habitat. These studies offer several advantages over other indicators of environmental quality (see Karr et al. 1986 and Karr 1987, 1991) and are relevant to assessment of the biotic integrity of streams such as Mitchell Branch. For example, fish communities include several trophic levels and species that are at or near the end of food chains. Consequently, they potentially integrate the direct effects of water quality and habitat changes on primary producers (periphyton) and consumers (benthic invertebrates) that are utilized for food. Because of these trophic interrelationships, the well-being of fish populations has often been used as an index of water quality (e.g., Weber 1973; Greeson et al. 1977; Karr et al. 1986). Statements about the condition of the fish community are often better understood by the general public than statements about the condition of diatoms or benthic macroinvertebrates (Karr 1981).

The initial objectives of the instream fish monitoring task (Subtask $4 \mathrm{~b}$ of the BMAP, as described in Loar et al. 1992a) were (1) to characterize spatial and temporal patterns in the distribution and abundance of fishes in Mitchell Branch and (2) to document any possible effects of new pollution abatement facilities on fish community structure and function.

\subsubsection{Materials and Methods}

Quantitative sampling of the fish population was conducted in Mitchell Branch by electrofishing biannually in fall 1990 through fall 1993. Four sites in Mitchell Branch [MIKs 0.45, 0.54, 0.71 and 0.78] were sampled from fall 1990 through fall 1992 (Fig. 2.2). Beginning spring 1993, only MIKs 0.45 and 0.71 were sampled. Similar quantitative samples were made at two nearby reference sites (GCK 2.4 and SCK 2.2) for comparisons of population parameters. Grassy Creek was sampled in fall 1990 through fall 1992 and Scarboro Creek was sampled spring 1991 through fall 1993. Stream conditions have declined 
at Grassy Creek and, therefore, Scarboro Creek was added as a new reference site beginning in spring 1991. The resulting data were used to (1) determine species composition, (2) estimate population size (numbers and biomass per unit area), (3) determine length-frequency, and (4) determine annual production. The lengths of the sampling reaches ranged from 30 to $54 \mathrm{~m}$ at Mitchell Branch and from 36 to $60 \mathrm{~m}$ at the reference sites (Table 6.1). Lengths of the sampling reaches in Mitchell Branch and Grassy Creek were similar to those in 1988 through spring 1990. (Ryon 1994b).

\subsubsection{Field sampling procedures}

All stream sampling was conducted using one Smith-Root Model 15A backpack electrofisher. The unit has a self-contained, gasoline-powered generator capable of delivering up to $1200 \mathrm{~V}$ of pulsed direct current. A pulse frequency of 90 to $120 \mathrm{~Hz}$ was used, and the output voltage was adjusted to the optimal value (generally $300-500 \mathrm{~V}$ ) based on the specific conductance of the water. A circular (ring) electrode at the end of a fiberglass anode pole was fitted with a nylon net $(0.64-\mathrm{cm}$ mesh) to allow the electrofisher operator to collect stunned fish.

After 0.64-cm-mesh seines were placed across the upper and lower boundaries of the fish sampling site to restrict fish movement, a two- to five-person sampling team electrofished the site in an upstream direction on three consecutive passes. Depending upon the turbidity of the water, consecutive passes could not always be made immediately. Rather, fish were processed after each pass to allow sufficient time for the water to clear before another pass was initiated. Stunned fish were collected and stored, by pass, in buckets with small holes to allow fresh water to pass through the buckets during further sampling. When possible, aerators were used in buckets to reduce mortality.

Following electrofishing, fish were anesthetized with MS-222 (tricaine methanesulfonate), identified, measured to the nearest $0.1 \mathrm{~cm}$ (total length) and weighed on Pesola spring scales to the nearest $0.1 \mathrm{~g}$ (for fish less than $100 \mathrm{~g}$ ) or gram (for fish greater than $100 \mathrm{~g}$ ). Individuals were recorded by $1-\mathrm{cm}$ size classes and species. For the fall 1990 and spring 1991 sampling, after 25 individuals of a species-size class were measured and weighed, additional members of that size class were only measured. Beginning in fall 1991,10 individuals of a species-size class were measured and weighed, and additional members of that size class were only measured. Later, length-weight regressions were determined using Railsback et al. (1989) 
Table 6.1. Length, mean width, mean depth, surface area, and pool to riffle ratio of fish sampling sites in Mitchell Branch and in two reference streams,

Grassy Creek and Scarboro Creek, for each sampling date

\begin{tabular}{|c|c|c|c|c|c|c|}
\hline $\begin{array}{l}\text { Site }^{a} \\
(\mathrm{~km})\end{array}$ & Date & $\begin{array}{l}\text { Length } \\
\text { (m) }\end{array}$ & $\begin{array}{c}\text { Mean } \\
\text { width (m) }\end{array}$ & $\begin{array}{c}\text { Mean } \\
\text { Depth }(\mathrm{cm})\end{array}$ & $\begin{array}{c}\text { Surface } \\
\text { area }\left(\mathrm{m}^{2}\right)\end{array}$ & $\begin{array}{l}\text { Pool-riffle } \\
\text { ratio }\end{array}$ \\
\hline MIK 0.45 & $09 / 25 / 90$ & 35 & 1.9 & 12.0 & 67 & 1.9 \\
\hline MIK 0.45 & $04 / 29 / 91$ & 30 & 1.8 & 10.7 & 54 & 14.0 \\
\hline MIK 0.45 & $11 / 04 / 91$ & 30 & 1.5 & 9.8 & 45 & 14.0 \\
\hline MIK 0.45 & $05 / 13 / 92$ & 31 & 1.8 & 14.0 & 56 & $\mathrm{p}^{b}$ \\
\hline MIK 0.45 & $11 / 10 / 92$ & 30 & 1.8 & 14.3 & 54 & 14.0 \\
\hline MIK 0.45 & $04 / 19 / 93$ & 31 & 1.8 & 11.3 & 56 & 2.1 \\
\hline MIK 0.45 & $10 / 15 / 93$ & 33 & 1.5 & 7.3 & 50 & 3.1 \\
\hline MaK 0.54 & $09 / 25 / 90$ & 40 & 1.5 & 9.3 & 60 & 2.1 \\
\hline MIK 0.54 & $04 / 29 / 91$ & 39 & 1.2 & 8.2 & 47 & 0.5 \\
\hline MIK 0.54 & $11 / 04 / 91$ & 38 & 1.0 & 8.4 & 38 & 2.5 \\
\hline MIK 0.54 & $05 / 12 / 92$ & 39 & 1.2 & 8.1 & 47 & 1.3 \\
\hline MIK 0.54 & $11 / 10 / 92$ & 39 & 1.2 & 8.9 & 47 & 1.6 \\
\hline MIK 0.71 & $09 / 25 / 90$ & 50 & 1.3 & 10.3 & 65 & 1.0 \\
\hline MIK 0.71 & $05 / 01 / 91$ & 54 & 1.0 & 8.7 & 54 & 0.9 \\
\hline MIK 0.71 & $11 / 05 / 91$ & 34 & 0.9 & 4.8 & 31 & 1.1 \\
\hline MIK 0.71 & $05 / 13 / 92$ & 39 & 1.0 & 6.2 & 39 & 0.6 \\
\hline MIK 0.71 & $11 / 10 / 92$ & 38 & 1.1 & 6.8 & 42 & 0.7 \\
\hline MIK 0.71 & $04 / 19 / 93$ & 38 & 1.6 & 12.5 & 61 & 0.7 \\
\hline MIK 0.71 & $10 / 15 / 93$ & 38 & 1.2 & 9.4 & 46 & 1.7 \\
\hline MIK 0.78 & $09 / 25 / 90$ & 45 & 1.0 & 9.0 & 45 & 1.4 \\
\hline MIK 0.78 & $05 / 01 / 91$ & 44 & 1.0 & 11.3 & 44 & 2.1 \\
\hline MIK 0.78 & $11 / 05 / 91$ & 47 & 1.0 & 8.0 & 47 & 4.9 \\
\hline MIK 0.78 & $05 / 13 / 92$ & 48 & 1.1 & 9.9 & 53 & 1.4 \\
\hline MIK 0.78 & $11 / 10 / 92$ & 47 & 1.1 & 7.6 & 52 & 1.2 \\
\hline GCK 2.4 & $10 / 25 / 90$ & 36 & 1.5 & 8.5 & 54 & $\mathbf{P}$ \\
\hline GCK 2.4 & $03 / 28 / 91$ & 60 & 2.1 & 13.0 & 126 & 0.8 \\
\hline GCK 2.4 & $11 / 01 / 91$ & 42 & 1.6 & 10.0 & 67 & $\mathbf{P}$ \\
\hline GCK 2.4 & $04 / 08 / 92$ & 57 & 1.7 & 7.3 & 97 & 0.6 \\
\hline GCK 2.4 & $12 / 09 / 92$ & 59 & 1.1 & 8.0 & 65 & 0.6 \\
\hline SCK 2.2 & $05 / 08 / 91$ & 38 & 2.2 & 15.1 & 84 & 0.5 \\
\hline SCK 2.2 & $11 / 18 / 91$ & 36 & 2.0 & 16.0 & 72 & 2.0 \\
\hline SCK 2.2 & $04 / 23 / 92$ & 34 & 2.1 & 17.7 & 71 & 2.4 \\
\hline SCK 2.2 & $12 / 14 / 92$ & 41 & 1.8 & 15.8 & 74 & 1.1 \\
\hline SCK 2.2 & $05 / 18 / 93$ & 40 & 1.9 & 13.8 & 76 & 1.0 \\
\hline SCK 2.2 & $10 / 28 / 93$ & 40 & 1.7 & 14.5 & 68 & 1.0 \\
\hline
\end{tabular}

${ }^{a} \mathrm{MIK}=$ Mitchell Branch kilometer; GCK = Grassy Creek kilometer; SCK $=$ Scarboro Creek kilometer.

${ }^{b} \mathrm{P}=$ Stream was a continuous pool; no riffle present. 
to estimate weights of unweighed fish. Other data recorded (if possible to determine) included sex, reproductive state, whether the fish was unusually plump or emaciated, deposition (i.e., dead, or retained for laboratory identification and reference collection), and presence of any abnormalities (e.g., external parasites, skeletal deformities, etc.). After processing fish from all passes, the fish were allowed to recover fully from the anesthesia and were returned to the stream. Any additional mortality that occurred as a result of processing was noted at that time.

In addition to data on individual fish, selected physical and chemical parameters were measured, and sampling effort was recorded. An Horiba Model U-7 battery-powered field sampler was used to measure conductivity, $\mathrm{pH}$, water temperature, and dissolved oxygen content. An HF Instruments Model DRT-15 turbidimeter was used to measure turbidity. The duration of the electrofishing effort was recorded and a visual estimate was made of percentage cloud cover. Following completion of fish sampling, the length, width, and depth of the sampling reach were measured at each site.

\subsubsection{Data analysis}

\section{Population size}

Species population estimates were obtained using the three-pass removal method of Carle and Strub (1978). Biomass was estimated by multiplying the population estimate by the mean weight of the individuals. To calculate density and biomass per unit area, total numbers and biomass were divided by the water surface area (in square meters) of the study reach. For each sampling date, surface area was estimated by multiplying the length of the sampling reach by the mean width based on measurements taken at 5-m intervals (Table 6.1). These data were compiled and analyzed by a comprehensive Fortran 77 program developed by Railsback et al. (1989).

\section{Length-frequency analyses}

The population structures of the most abundant species were examined by length frequencies generated by the Fortran program. Length data for the selected species were separated into 1- or 2-cm size classes, depending on the maximum size of the species. These frequencies indicated whether the population included young and adult individuals and if any unusual mortality had affected a size class (Anderson and Gutreuter 1983). 


\section{Annual production}

Annual production was estimated using a size-frequency method (Garman and Waters 1983). Production was calculated for each site (where data was available) from spring 1990 to spring 1991, spring 1991 to spring 1992, and spring 1992 to spring 1993. Production values were calculated from estimated biomass and population estimates. Annual production estimates for Mitchell Branch were compared with published values and those calculated for other streams on the ORR.

\subsubsection{Results and Discussion}

\subsubsection{Species richness and composition}

A total of eight species were collected in the quantitative surveys of the four sites in Mitchell Branch from fall 1990 through fall 1993 (Table 6.2). In comparison, a total of 6 species were found at Grassy Creek in 5 surveys from fall 1990 through fall 1992; and a total of 16 species were found in 6 surveys of Scarboro Creek from spring 1991 through fall 1993. Species richness ranged from 0 to 6 species at Mitchell Branch, 3 to 5 species at Grassy Creek, and from 7 to 13 species at Scarboro Creek for the sampling periods (Table 6.3).

The fish community in Mitchell Branch in fall 1990 and spring 1991 (Tables 6.4 and 6.5) consisted of five species, central stoneroller (Campostoma anomalum), blacknose dace (Rhinichthys atratulus), creek chub (Semotilus atromaculatus), redbreast sunfish (Lepomis auritus), and green sunfish ( $L$. cyanellus). The blacknose dace, creek chub, and redbreast sunfish are species that appear to be insensitive to many habitat and water quality stresses and would be considered tolerant species in an impact assessment methodology such as the Index of Biotic Integrity (Karr et al. 1986). Sampling in January 1988 through fall 1989 revealed the absence of fish at MIKs $0.45,0.54$, and 0.71 (Ryon 1994b). There were no fish collected in fall 1990 from MIKs $0.45,0.54$, or 0.71 . The fish community at MIK 0.78 in fall 1990 and spring 1991 was similar to the fish community in January 1988 through April/May 1989 (Ryon 1994b) with the exception of the presence of the central stoneroller and green sunfish.

Three additional species, banded sculpin (Cottus carolinae), green sunfish (Lepomis cyanellus), and bluegill ( $L$. macrochirus), were found infrequently during sampling from fall 1991 through fall 1993 (Tables 6.6 through 6.10) at MIK 0.78. These species had not previously been collected in Mitchell Branch since sampling began in September 1986 (Ryon 1993 and 1994b). 
Table 6.2. Fish species composition and occurrence (number of sampling periods when found) in Mitchell Branch, Grassy Creek, and Scarboro Creek, fall 1990 through fall 1993

\begin{tabular}{|c|c|c|c|c|c|c|}
\hline \multirow[b]{2}{*}{ Species } & \multicolumn{6}{|c|}{ Sitese } \\
\hline & $\begin{array}{c}\text { MIK } 0.45 \\
\left(7^{6}\right)\end{array}$ & $\begin{array}{c}\text { MIK } 0.54 \\
(5)\end{array}$ & $\begin{array}{c}\text { MIK } 0.71 \\
(7)\end{array}$ & $\begin{array}{c}\text { MIK } 0.78 \\
(5) \\
\end{array}$ & $\begin{array}{c}\text { GCK } 2.4 \\
(5)\end{array}$ & $\begin{array}{c}\text { SCK } 2.2 \\
(6)\end{array}$ \\
\hline \multicolumn{7}{|l|}{ Cyprinidae } \\
\hline $\begin{array}{l}\text { Central stoneroller } \\
\text { (Campostoma anomalum) }\end{array}$ & $2^{c}$ & 1 & 4 & 2 & - & 6 \\
\hline $\begin{array}{l}\text { Spotfin shiner } \\
\text { (Cyprinella spiloptera) }\end{array}$ & - & - & - & - & - & 3 \\
\hline $\begin{array}{l}\text { Striped shiner } \\
\text { (Luxilus chrysocephalus) }\end{array}$ & - & - & 1 & 1 & 1 & - \\
\hline $\begin{array}{l}\text { Bluntnose minnow } \\
\text { (Pimephales notatus) }\end{array}$ & - & - & - & - & - & 4 \\
\hline $\begin{array}{l}\text { Fathead minnow } \\
\text { (Pimephales promelas) }\end{array}$ & - & - & - & - & - & 1 \\
\hline $\begin{array}{l}\text { Blacknose dace } \\
\text { (Rhinichthys atratulus) }\end{array}$ & 5 & 3 & 6 & 5 & 5 & 6 \\
\hline $\begin{array}{l}\text { Creek chub } \\
\text { (Semotilus atromaculatus) }\end{array}$ & 6 & 4 & 6 & - & 5 & 4 \\
\hline Catostomidae & & & & & & \\
\hline $\begin{array}{l}\text { White sucker } \\
\text { (Catostomus commersoni) }\end{array}$ & - & - & - & - & 4 & - \\
\hline $\begin{array}{l}\text { Northern hogsucker } \\
\text { (Hypentelium nigricans) }\end{array}$ & - & - & - & - & - & 2 \\
\hline $\begin{array}{l}\text { Ictaluridae } \\
\text { Yellow bullhead } \\
\text { (Ameiurus natalis) }\end{array}$ & - & - & - & - & - & 4 \\
\hline $\begin{array}{l}\text { Poeciliidae } \\
\text { Western mosquitofish } \\
\text { (Gambusia affinis) }\end{array}$ & - & - & - & - & - & 1 \\
\hline $\begin{array}{l}\text { Cottidae } \\
\text { Banded sculpin } \\
\text { (Cottus carolinae) }\end{array}$ & - & - & - & 3 & 2 & 6 \\
\hline Centrarchidae & & & & & & \\
\hline $\begin{array}{l}\text { Redbreast sunfish } \\
\text { (Lepomis auritus) }\end{array}$ & 1 & - & 2 & 4 & - & 4 \\
\hline $\begin{array}{l}\text { Green sunfish } \\
\text { (Lepomis cyanellus) }\end{array}$ & - & - & - & 1 & 2 & 6 \\
\hline $\begin{array}{l}\text { Bluegill } \\
\text { (Lepomis macrochirus) }\end{array}$ & - & - & - & 1 & - & 4 \\
\hline $\begin{array}{l}\text { Hybrid sunfish } \\
\text { (Lepomis spp.) }\end{array}$ & - & - & - & - & - & 1 \\
\hline $\begin{array}{l}\text { Largemouth bass } \\
\text { (Micropterus salmoides) }\end{array}$ & - & - & - & - & - & 2 \\
\hline $\begin{array}{l}\text { Percidae } \\
\text { Logperch } \\
\text { (Percina caprodes) }\end{array}$ & - & - & - & - & - & 4 \\
\hline Number of species $(\mathrm{N})$ & 4 & 3 & 5 & 7 & 6 & 16 \\
\hline
\end{tabular}

${ }^{a}$ MCK = Mitchell Branch kilometer; GCK = Grassy Creek kilometer; SCK = Scarboro Creek kilometer.

Sumbers represent the number of sampling periods for each site.

'Numbers represent the number of sampling periods that a given species was collected at the site and a 'hyphen' indicates that the species was not collected. 
Table 6.3. Total fish density, total biomass, and species richness in Mitchell Branch and two reference streams; Grassy Creek and Scarboro Creek, for fall 1990-1993 and spring 1991-1993

\begin{tabular}{|c|c|c|c|c|c|c|}
\hline \multirow[b]{2}{*}{ Sampling periods ${ }^{a}$} & \multicolumn{6}{|c|}{ Sites $^{b}$} \\
\hline & $\begin{array}{c}\text { MIK } \\
0.45\end{array}$ & $\begin{array}{c}\text { MIK } \\
0.54\end{array}$ & $\begin{array}{c}\text { MIK } \\
0.71\end{array}$ & $\begin{array}{c}\text { MIK } \\
0.78\end{array}$ & $\begin{array}{c}\text { GCK } \\
2.4\end{array}$ & $\begin{array}{c}\text { SCK } \\
2.2\end{array}$ \\
\hline \multicolumn{7}{|l|}{ Fall 1990} \\
\hline $\begin{array}{l}\text { Total density (individuals } / \mathrm{m}^{2} \text { ) } \\
\text { Total biomass }\left(\mathrm{g} / \mathrm{m}^{2}\right) \\
\text { Species richness }\end{array}$ & $\mathrm{NF}^{c}$ & $\mathrm{NF}$ & NF & $\begin{array}{c}4.20 \\
6.00 \\
3\end{array}$ & $\begin{array}{c}3.41 \\
5.80 \\
3\end{array}$ & $\mathrm{NS}^{d}$ \\
\hline \multicolumn{7}{|l|}{ Spring 1991} \\
\hline $\begin{array}{l}\text { Total density } \\
\text { Total biomass } \\
\text { Species richness }\end{array}$ & $\begin{array}{c}0.04 \\
0.22 \\
1\end{array}$ & $\begin{array}{c}0.02 \\
0.36 \\
1\end{array}$ & $\begin{array}{c}0.35 \\
2.30 \\
2\end{array}$ & $\begin{array}{c}2.09 \\
6.77 \\
4\end{array}$ & $\begin{array}{c}0.41 \\
1.84 \\
4\end{array}$ & $\begin{array}{c}2.15 \\
11.41 \\
7\end{array}$ \\
\hline \multicolumn{7}{|l|}{ Fall 1991} \\
\hline $\begin{array}{l}\text { Total density } \\
\text { Total biomass } \\
\text { Species richness }\end{array}$ & $\begin{array}{c}6.00 \\
12.35 \\
2\end{array}$ & $\begin{array}{c}5.00 \\
11.40 \\
2\end{array}$ & $\begin{array}{c}3.71 \\
5.82 \\
2\end{array}$ & $\begin{array}{c}7.10 \\
14.50 \\
4\end{array}$ & $\begin{array}{c}4.35 \\
5.63 \\
4\end{array}$ & $\begin{array}{c}6.19 \\
26.55 \\
13\end{array}$ \\
\hline \multicolumn{7}{|l|}{ Spring 1992} \\
\hline $\begin{array}{l}\text { Total density } \\
\text { Total biomass } \\
\text { Species richness }\end{array}$ & $\begin{array}{c}0.59 \\
3.00 \\
3\end{array}$ & $\begin{array}{c}0.38 \\
0.89 \\
2\end{array}$ & $\begin{array}{c}2.62 \\
8.34 \\
3\end{array}$ & $\begin{array}{c}2.99 \\
10.35 \\
5\end{array}$ & $\begin{array}{c}1.51 \\
2.31 \\
3\end{array}$ & $\begin{array}{c}2.75 \\
25.60 \\
11\end{array}$ \\
\hline \multicolumn{7}{|l|}{ Fall 1992} \\
\hline $\begin{array}{l}\text { Total density } \\
\text { Total biomass } \\
\text { Species richness }\end{array}$ & $\begin{array}{c}3.43 \\
5.53 \\
3\end{array}$ & $\begin{array}{c}3.77 \\
7.94 \\
3\end{array}$ & $\begin{array}{c}4.07 \\
9.97 \\
3\end{array}$ & $\begin{array}{c}8.89 \\
23.93 \\
6\end{array}$ & $\begin{array}{c}4.37 \\
4.00 \\
5\end{array}$ & $\begin{array}{c}4.91 \\
32.21 \\
9\end{array}$ \\
\hline \multicolumn{7}{|l|}{ Spring 1993} \\
\hline $\begin{array}{l}\text { Total density } \\
\text { Total biomass } \\
\text { Species richness }\end{array}$ & $\begin{array}{c}2.41 \\
7.38 \\
2\end{array}$ & NS & $\begin{array}{c}4.53 \\
40.37 \\
5\end{array}$ & NS & NS & $\begin{array}{c}4.04 \\
42.23 \\
7\end{array}$ \\
\hline \multicolumn{7}{|l|}{ Fall 1993} \\
\hline $\begin{array}{l}\text { Total density } \\
\text { Total biomass } \\
\text { Species richness }\end{array}$ & $\begin{array}{c}4.48 \\
4.83 \\
3\end{array}$ & NS & $\begin{array}{c}6.29 \\
22.58 \\
4\end{array}$ & NS & NS & $\begin{array}{c}7.56 \\
48.33 \\
11\end{array}$ \\
\hline
\end{tabular}

${ }^{a}$ The months sampled in the spring and fall were: September 1990 for Mitchell Branch; October 1990 for Grassy Creek; April and May 1991 for Mitchell Branch; May 1991 for Scarboro Creek; March 1991 for Grassy Creek; November 1991 for Mitchell Branch, Grassy Creek, and Scarboro Creek; May 1992 for Mitchell Branch; April 1992 for Grassy Creek and Scarboro Creek; November 1992 for Mitchell Branch; December 1992 for Grassy Creek and Scarboro Creek; April 1993 for Mitchell Branch; May 1993 for Scarboro Creek; October 1993 for Mitchell Branch and Scarboro Creek.

${ }^{b} \mathrm{MCK}=$ =Mitchell Branch kilometer; GCK=Grassy Creek kilometer; SCK=Scarboro Creek kilometer.

$\mathrm{NF}=$ No fish taken in sample.

NS=Not sampled. 
Table 6.4. Fish densities (number of individuals per square meter) and biomass (grams per square meter) in Mitchell Branch and in two reference streams, Grassy Creek and Scarboro Creek, for fall 1990

\begin{tabular}{|c|c|c|c|c|c|c|}
\hline \multirow[b]{3}{*}{ Species } & \multicolumn{6}{|c|}{$\begin{array}{c}\text { Density } \\
\text { (Biomass) }\end{array}$} \\
\hline & \multicolumn{6}{|c|}{ Sites $^{a}$} \\
\hline & $\begin{array}{l}\text { MIK } \\
0.45\end{array}$ & $\begin{array}{l}\text { MIK } \\
0.54\end{array}$ & $\begin{array}{l}\text { MIK } \\
0.71\end{array}$ & $\begin{array}{l}\text { MIK } \\
0.78\end{array}$ & $\begin{array}{c}\text { GCK } \\
2.4\end{array}$ & $\begin{array}{c}\text { SCK } \\
2.2\end{array}$ \\
\hline $\begin{array}{l}\text { Cyprinidae } \\
\text { Central stoneroller }\end{array}$ & $\begin{array}{c}\mathrm{NF}^{b} \\
-\end{array}$ & NF & NF & $\begin{array}{c}- \\
0.18 \\
(1.45)\end{array}$ & $\begin{array}{l}- \\
-\end{array}$ & $\begin{array}{c}\mathrm{NS}^{c} \\
-\end{array}$ \\
\hline Blacknose dace & - & - & - & $\begin{array}{c}2.58 \\
(1.50)\end{array}$ & $\begin{array}{c}2.54 \\
(2.11)\end{array}$ & - \\
\hline Creek chub & - & - & - & $\begin{array}{c}1.44 \\
(3.05)\end{array}$ & $\begin{array}{c}0.83 \\
(3.25)\end{array}$ & - \\
\hline $\begin{array}{l}\text { Cottidae } \\
\text { Banded sculpin }\end{array}$ & - & - & - & - & $\begin{array}{c}0.04 \\
(0.44) \\
\end{array}$ & - \\
\hline Number of species & 0 & 0 & 0 & 3 & 3 & NS \\
\hline Total density & 0 & 0 & 0 & 4.20 & 3.41 & - \\
\hline Total biomass & 0 & 0 & 0 & 6.00 & 5.80 & - \\
\hline
\end{tabular}

${ }^{a} \mathrm{MIK}=$ Mitchel Branch kilometer; GCK $=$ Grassy Creek kilometer; SCK $=$ Scarboro Creek kilometer.

${ }^{b} \mathrm{NF}=$ No fish taken in sample.

QNS $=$ Not sampled. 
Table 6.5. Fish densities and biomass in Mitchell Branch and in two reference streams, Grassy Creek and Scarboro Creek, for spring 1991

\begin{tabular}{|c|c|c|c|c|c|c|}
\hline \multirow[b]{3}{*}{ Species } & \multicolumn{6}{|c|}{$\begin{array}{l}\left.\text { Density (number of individuals } / \mathrm{m}^{2}\right) \\
\text { (Biomass) }\left(\mathrm{g} / \mathrm{m}^{2}\right)\end{array}$} \\
\hline & \multicolumn{6}{|c|}{ Sites $^{a}$} \\
\hline & $\begin{array}{l}\text { MIK } \\
0.45\end{array}$ & $\begin{array}{l}\text { MIK } \\
0.54\end{array}$ & $\begin{array}{l}\mathrm{MIK} \\
0.71\end{array}$ & $\begin{array}{l}\text { MIK } \\
0.78\end{array}$ & $\begin{array}{c}\mathrm{GCK} \\
2.4\end{array}$ & $\begin{array}{r}\text { SCK } \\
2.2\end{array}$ \\
\hline \multicolumn{7}{|l|}{ Cyprinidae } \\
\hline Central stoneroller & - & - & - & - & - & $\begin{array}{c}0.16 \\
(2.00)\end{array}$ \\
\hline Blacknose dace & - & - & $\begin{array}{c}0.11 \\
(0.43)\end{array}$ & $\begin{array}{c}1.16 \\
(1.57)\end{array}$ & $\begin{array}{c}0.20 \\
(0.19)\end{array}$ & $\begin{array}{c}0.52 \\
(1.92)\end{array}$ \\
\hline Creek chub & $\begin{array}{c}0.04 \\
(0.22)\end{array}$ & $\begin{array}{c}0.02 \\
(0.36)\end{array}$ & $\begin{array}{c}0.24 \\
(1.87)\end{array}$ & $\begin{array}{c}0.86 \\
(4.26)\end{array}$ & $\begin{array}{c}0.18 \\
(1.10)\end{array}$ & $\begin{array}{c}0.04 \\
(0.08)\end{array}$ \\
\hline \multicolumn{7}{|l|}{ Catostomidae } \\
\hline White sucker & - & - & - & - & $\begin{array}{c}0.01 \\
(0.36)\end{array}$ & $\overline{0.02}$ \\
\hline Northern hogsucker & - & - & - & - & - & $(0.69)$ \\
\hline \multicolumn{7}{|l|}{ Cottidae } \\
\hline Banded sculpin & - & - & - & - & $\begin{array}{c}0.02 \\
(0.19)\end{array}$ & $\begin{array}{c}1.25 \\
(5.68)\end{array}$ \\
\hline \multicolumn{7}{|l|}{ Centrarchidae } \\
\hline Redbreast sunfish & - & - & - & $\begin{array}{c}0.02 \\
(0.12)\end{array}$ & - & - \\
\hline Green sunfish & - & - & - & $\begin{array}{c}0.05 \\
(0.82)\end{array}$ & - & $\begin{array}{c}0.12 \\
(0.66)\end{array}$ \\
\hline \multicolumn{7}{|l|}{ Percidae } \\
\hline Logperch & - & - & - & - & - & $\begin{array}{c}0.04 \\
(0.38)\end{array}$ \\
\hline Number of species & 1 & 1 & 2 & 4 & 4 & 7 \\
\hline Total density & 0.04 & 0.02 & 0.35 & 2.09 & 0.41 & 2.15 \\
\hline Total biomass & 0.22 & 0.36 & 2.30 & 6.77 & 1.84 & 11.41 \\
\hline
\end{tabular}

${ }^{a} \mathrm{MIK}=$ Mitchell Branch kilometer; $\mathrm{GCK}=$ Grassy Creek kilometer; $\mathrm{SCK}=$ Scarboro Creek kilometer. 
Table 6.6. Fish densities and biomass in Mitchell Branch and in two reference streams, Grassy Creek and Scarboro Creek, for fall 1991

\begin{tabular}{|c|c|c|c|c|c|c|}
\hline \multirow[b]{3}{*}{ Species } & \multicolumn{6}{|c|}{$\begin{array}{l}\text { Density (as number of individuals } / \mathrm{m}^{2} \text { ) } \\
\text { (Biomass) (as } \mathrm{g} / \mathrm{m}^{2} \text { ) }\end{array}$} \\
\hline & \multicolumn{6}{|c|}{ Sites $^{a}$} \\
\hline & $\underset{0.45}{\mathrm{MIK}}$ & $\begin{array}{c}\text { MIK } \\
0.54\end{array}$ & $\begin{array}{r}\text { MIK } \\
0.71\end{array}$ & $\begin{array}{c}\text { MIK } \\
0.78\end{array}$ & $\begin{array}{c}\text { GCK } \\
2.4\end{array}$ & $\begin{array}{c}\text { SCK } \\
2.2\end{array}$ \\
\hline \multicolumn{7}{|l|}{ Cyprinidae } \\
\hline Central stoneroller & - & - & - & - & - & $\begin{array}{c}1.53 \\
(8.65)\end{array}$ \\
\hline Spotfin shiner & - & - & - & - & - & $\begin{array}{c}0.69 \\
(1.70)\end{array}$ \\
\hline Bluntnose minnow & - & - & - & - & - & $\begin{array}{r}0.71 \\
(0.89)\end{array}$ \\
\hline Blacknose dace & $\begin{array}{c}1.84 \\
(2.73)\end{array}$ & $\begin{array}{c}1.55 \\
(1.67)\end{array}$ & $\begin{array}{c}1.58 \\
(1.24)\end{array}$ & $\begin{array}{c}3.60 \\
(3.63)\end{array}$ & $\begin{array}{c}3.24 \\
(2.15)\end{array}$ & $\begin{array}{c}0.61 \\
(2.59)\end{array}$ \\
\hline Creek chub & $\begin{array}{c}4.16 \\
(9.62)\end{array}$ & $\begin{array}{c}3.45 \\
(9.73)\end{array}$ & $\begin{array}{c}2.13 \\
(4.58)\end{array}$ & $\begin{array}{c}3.40 \\
(10.03)\end{array}$ & $\begin{array}{c}0.72 \\
(2.54)\end{array}$ & $\begin{array}{r}0.06 \\
(0.41)\end{array}$ \\
\hline $\begin{array}{l}\text { Catostomidae } \\
\text { White sucker }\end{array}$ & - & $\cdot$ & - & - & $\begin{array}{c}0.37 \\
(0.77)\end{array}$ & - \\
\hline $\begin{array}{l}\text { Poeciliidae } \\
\text { Western mosquitofish }\end{array}$ & - & - & - & - & - & $\begin{array}{c}0.01 \\
(0.01)\end{array}$ \\
\hline $\begin{array}{l}\text { Cottidae } \\
\text { Banded sculpin }\end{array}$ & - & - & - & $\begin{array}{c}0.04 \\
(0.16)\end{array}$ & - & $\begin{array}{r}1.58 \\
(5.98)\end{array}$ \\
\hline \multicolumn{7}{|l|}{ Centrarchidae } \\
\hline Redbreast sunfish & - & - & - & $\begin{array}{c}0.06 \\
(0.68)\end{array}$ & - & $\begin{array}{c}0.17 \\
(0.85)\end{array}$ \\
\hline Green sunfish & - & - & - & - & $\begin{array}{c}0.02 \\
(0.17)\end{array}$ & $\begin{array}{c}0.46 \\
(3.91)\end{array}$ \\
\hline Bluegill & - & - & - & - & - & $\begin{array}{c}0.29 \\
(1.00)\end{array}$ \\
\hline Hybrid sunfish & - & - & - & - & - & $\begin{array}{c}0.01 \\
(0.10)\end{array}$ \\
\hline Largemouth bass & - & - & - & - & - & $\begin{array}{c}0.01 \\
(0.06)\end{array}$ \\
\hline $\begin{array}{l}\text { Percidae } \\
\text { Logperch }\end{array}$ & - & - & - & - & - & $\begin{array}{r}0.06 \\
(0.40)\end{array}$ \\
\hline Number of species & 2 & 2 & 2 & 4 & 4 & 13 \\
\hline Total density & 6.00 & 5.00 & 3.71 & 7.10 & 4.35 & 6.19 \\
\hline Total biomass & 12.35 & 11.40 & 5.82 & 14.50 & 5.63 & 26.55 \\
\hline
\end{tabular}

${ }^{a} \mathrm{MIK}=$ Mitchell Branch kilometer; $\mathrm{GCK}=$ Grassy Creek kilometer; SCK $=$ Scarboro Creek kilometer. 
Table 6.7. Fish densities and biomass in Mitchell Branch and in two reference streams, Grassy Creek and Scarboro Creek, for spring 1992

\begin{tabular}{|c|c|c|c|c|c|c|}
\hline \multirow[b]{3}{*}{ Species } & \multicolumn{6}{|c|}{$\begin{array}{l}\text { Density (as number of individuals } / \mathrm{m}^{2} \text { ) } \\
\text { (Biomass) (as } \mathrm{g} / \mathrm{m}^{2} \text { ) }\end{array}$} \\
\hline & \multicolumn{6}{|c|}{ Sites $^{a}$} \\
\hline & $\begin{array}{c}\text { MIK } \\
0.45\end{array}$ & $\underset{0.54}{\operatorname{MIK}}$ & $\underset{0.71}{\mathrm{MIK}}$ & $\begin{array}{l}\text { MIK } \\
0.78\end{array}$ & $\begin{array}{c}\text { GCK } \\
2.4\end{array}$ & $\begin{array}{c}\mathrm{SCK} \\
2.2\end{array}$ \\
\hline \multicolumn{7}{|l|}{ Cyprinidae } \\
\hline Central stoneroller & - & - & $\begin{array}{c}0.03 \\
(0.58)\end{array}$ & - & - & $\begin{array}{c}0.87 \\
(10.00)\end{array}$ \\
\hline Striped shiner & - & - & - & $\begin{array}{c}0.04 \\
(0.15)\end{array}$ & - & - \\
\hline Bluntnose minnow & - & - & - & - & - & $\begin{array}{c}0.04 \\
(0.10)\end{array}$ \\
\hline Blacknose dace & $\begin{array}{c}0.23 \\
(0.67)\end{array}$ & $\begin{array}{c}0.34 \\
(0.83)\end{array}$ & $\begin{array}{c}2.23 \\
(6.06)\end{array}$ & $\begin{array}{c}1.38 \\
(2.88)\end{array}$ & $\begin{array}{c}1.01 \\
(0.94)\end{array}$ & $\begin{array}{c}0.37 \\
(1.21)\end{array}$ \\
\hline Creek chub & $\begin{array}{c}0.34 \\
(1.95)\end{array}$ & $\begin{array}{l}0.04 \\
(0.06)\end{array}$ & $\begin{array}{c}0.36 \\
(1.70)\end{array}$ & $\begin{array}{c}1.51 \\
(6.96)\end{array}$ & $\begin{array}{c}0.39 \\
(1.08)\end{array}$ & $\begin{array}{c}0.01 \\
(0.10)\end{array}$ \\
\hline \multicolumn{7}{|l|}{ Catostomidae } \\
\hline White sucker & - & - & - & - & $\begin{array}{c}0.11 \\
(0.29)\end{array}$ & - \\
\hline Northern hogsucker & - & - & - & - & - & $\begin{array}{c}0.07 \\
(4.96)\end{array}$ \\
\hline \multicolumn{7}{|l|}{ Ictaluridae } \\
\hline Yellow bullhead & - & - & - & - & - & $\begin{array}{c}0.01 \\
(0.18)\end{array}$ \\
\hline \multicolumn{7}{|l|}{ Cottidae } \\
\hline Banded sculpin & - & - & - & $\begin{array}{c}0.04 \\
(0.24)\end{array}$ & - & $\begin{array}{c}1.00 \\
(5.36)\end{array}$ \\
\hline \multicolumn{7}{|l|}{ Centrarchidae } \\
\hline Redbreast sunfish & $\begin{array}{c}0.02 \\
(0.38)\end{array}$ & - & - & $\begin{array}{c}0.02 \\
(0.12)\end{array}$ & - & $\begin{array}{c}0.03 \\
(0.19)\end{array}$ \\
\hline Green sunfish & - & - & - & - & - & $\begin{array}{c}0.30 \\
(3.10)\end{array}$ \\
\hline Bluegill & - & - & - & - & - & $\begin{array}{c}0.04 \\
(0.25)\end{array}$ \\
\hline \multicolumn{7}{|l|}{ Percidae } \\
\hline Logperch & - & - & - & - & - & $\begin{array}{c}0.01 \\
(0.15)\end{array}$ \\
\hline Number of species & 3 & 2 & 3 & 5 & 3 & 11 \\
\hline Total density & 0.59 & 0.38 & 2.62 & 2.99 & 1.51 & 2.75 \\
\hline Total biomass & 3.00 & 0.89 & 8.34 & 10.35 & 2.31 & 25.60 \\
\hline
\end{tabular}

${ }^{a} \mathrm{MIK}=$ Mitchell Branch kilometer; GCK = Grassy Creek kilometer; SCK = Scarboro Creek kilometer. 
Table 6.8. Fish densities and biomass in Mitchell Branch and in two reference streams, Grassy Creek and Scarboro Creek, for fall 1992

\begin{tabular}{|c|c|c|c|c|c|c|}
\hline \multirow[b]{3}{*}{ Species } & \multicolumn{6}{|c|}{$\begin{array}{l}\text { Density (as number of individuals } / \mathrm{m}^{2} \text { ) } \\
\text { (Biomass) (as } \mathrm{g} / \mathrm{m}^{2} \text { ) }\end{array}$} \\
\hline & \multicolumn{6}{|c|}{ Sites $^{a}$} \\
\hline & $\begin{array}{l}\text { MIK } \\
0.45\end{array}$ & $\begin{array}{l}\text { MIK } \\
0.54\end{array}$ & $\begin{array}{l}\text { MOK } \\
0.71\end{array}$ & $\begin{array}{l}\text { MIK } \\
0.78\end{array}$ & $\begin{array}{l}\text { GCK } \\
2.4\end{array}$ & $\begin{array}{c}\text { SCK } \\
2.2\end{array}$ \\
\hline \multicolumn{7}{|l|}{ Cyprinidae } \\
\hline Central stoneroller & $\begin{array}{c}0.11 \\
(0.39)\end{array}$ & $\begin{array}{c}0.60 \\
(2.37)\end{array}$ & $\begin{array}{c}0.50 \\
(1.58)\end{array}$ & $\begin{array}{c}3.06 \\
(10.86)\end{array}$ & - & $\begin{array}{c}2.12 \\
(17.40)\end{array}$ \\
\hline Spotfin shiner & - & - & - & - & - & $\begin{array}{c}0.18 \\
(0.44)\end{array}$ \\
\hline Striped shiner & - & - & - & - & $\begin{array}{c}0.02 \\
(0.25)\end{array}$ & - \\
\hline Bluntnose minnow & - & - & - & - & - & $\begin{array}{c}0.61 \\
(1.05)\end{array}$ \\
\hline Blacknose dace & $\begin{array}{c}2.43 \\
(3.23)\end{array}$ & $\begin{array}{c}1.70 \\
(2.20)\end{array}$ & $\begin{array}{c}1.88 \\
(2.37)\end{array}$ & $\begin{array}{c}2.60 \\
(2.29)\end{array}$ & $\begin{array}{c}3.85 \\
(1.87)\end{array}$ & $\begin{array}{c}0.30 \\
(1.81)\end{array}$ \\
\hline Creek chub & $\begin{array}{c}0.89 \\
(1.91)\end{array}$ & $\begin{array}{c}1.47 \\
(3.37)\end{array}$ & $\begin{array}{c}1.69 \\
(6.02)\end{array}$ & $\begin{array}{l}3.15 \\
(9.83)\end{array}$ & $\begin{array}{c}0.42 \\
(1.33)\end{array}$ & - \\
\hline $\begin{array}{l}\text { Catostomidae } \\
\text { White sucker }\end{array}$ & - & - & - & - & $\begin{array}{c}0.06 \\
(0.48)\end{array}$ & - \\
\hline $\begin{array}{l}\text { Ictaluridae } \\
\text { Yellow bullhead }\end{array}$ & - & - & - & - & - & $\begin{array}{c}0.05 \\
(0.87)\end{array}$ \\
\hline $\begin{array}{l}\text { Cottidae } \\
\text { Banded sculpin }\end{array}$ & - & - & - & $\begin{array}{c}0.02 \\
(0.23)\end{array}$ & - & $\begin{array}{c}1.31 \\
(6.13)\end{array}$ \\
\hline $\begin{array}{l}\text { Centrarchidae } \\
\text { Redbreast sunfish }\end{array}$ & - & - & - & $\begin{array}{c}0.04 \\
(0.41)\end{array}$ & - & $\begin{array}{c}0.01 \\
(0.07)\end{array}$ \\
\hline Green sunfish & - & - & - & - & $\begin{array}{c}0.02 \\
(0.07)\end{array}$ & $\begin{array}{c}0.30 \\
(4.30)\end{array}$ \\
\hline Bluegill & - & - & - & $\begin{array}{c}0.02 \\
(0.31)\end{array}$ & - & $\begin{array}{c}0.03 \\
(0.14)\end{array}$ \\
\hline Number of species & 3 & 3 & 3 & 6 & 5 & 9 \\
\hline Total density & 3.43 & 3.77 & 4.07 & 8.89 & 4.37 & 4.91 \\
\hline Total biomass & 5.53 & 7.94 & 9.97 & 23.93 & 4.00 & 32.21 \\
\hline
\end{tabular}

${ }_{\mathrm{MIK}}=$ Mitchell Branch kilometer; GCK $=$ Grassy Creek kilometer; SCK $=$ Scarboro Creek kilometer. 
Table 6.9. Fish densities and biomass in Mitchell Branch and two reference streams, Grassy Creek and Scarboro Creek, for spring 1993

\begin{tabular}{|c|c|c|c|c|c|c|}
\hline \multirow[b]{3}{*}{ Species } & \multicolumn{6}{|c|}{$\begin{array}{c}\text { Density }^{a} \\
\text { (Biomass) }^{b}\end{array}$} \\
\hline & \multicolumn{6}{|c|}{ Sites $^{c}$} \\
\hline & $\begin{array}{c}\text { MIK } \\
0.45\end{array}$ & $\begin{array}{c}\text { MIK } \\
0.54\end{array}$ & $\begin{array}{r}\text { MIK } \\
0.71\end{array}$ & $\begin{array}{l}\text { MIK } \\
0.78\end{array}$ & $\begin{array}{r}\text { GCK } \\
2.4\end{array}$ & $\begin{array}{r}\text { SCK } \\
2.2\end{array}$ \\
\hline Cyprinidae & & $\mathrm{NS}^{d}$ & & NS & NS & \\
\hline Central stoneroller & - & - & $\begin{array}{c}1.08 \\
(8.78)\end{array}$ & $\cdot$ & - & $\begin{array}{c}2.49 \\
(31.76)\end{array}$ \\
\hline Striped shiner & - & - & $\begin{array}{c}0.02 \\
(0.21)\end{array}$ & - & - & - \\
\hline Blacknose dace & $\begin{array}{c}1.32 \\
(2.54)\end{array}$ & - & $\begin{array}{c}1.79 \\
(5.26)\end{array}$ & - & - & $\begin{array}{c}0.47 \\
(2.30)\end{array}$ \\
\hline Creek chub & $\begin{array}{c}1.09 \\
(4.84)\end{array}$ & - & $\begin{array}{c}1.61 \\
(25.51)\end{array}$ & - & - & $\begin{array}{c}0.03 \\
(0.32)\end{array}$ \\
\hline \multicolumn{7}{|l|}{ Ictaluridae } \\
\hline Yellow bullhead & - & - & - & - & - & $\begin{array}{c}0.01 \\
(0.96)\end{array}$ \\
\hline \multicolumn{7}{|l|}{ Cottidae } \\
\hline Banded sculpin & - & $\cdot$ & - & - & - & $\begin{array}{c}0.75 \\
(3.94)\end{array}$ \\
\hline \multicolumn{7}{|l|}{ Centrarchidae } \\
\hline Redbreast sunfish & - & - & $\begin{array}{c}0.03 \\
(0.61)\end{array}$ & - & - & - \\
\hline Green sunfish & - & - & - & - & - & $\begin{array}{c}0.16 \\
(1.69)\end{array}$ \\
\hline \multicolumn{7}{|l|}{ Percidae } \\
\hline Logperch & - & - & - & - & - & $\begin{array}{c}0.13 \\
(1.26) \\
\end{array}$ \\
\hline Number of species & 2 & NS & 5 & NS & NS & 7 \\
\hline Total density & 2.41 & & 4.53 & & & 4.04 \\
\hline Total biomass & 7.38 & & 40.37 & & & 42.23 \\
\hline
\end{tabular}

${ }^{a}$ Density expressed in number of individuals per square meter.

${ }^{b}$ Biomass, in parentheses, expressed in grams per square meter.

${ }^{\mathrm{M}} \mathrm{MIK}=$ Mitchell Branch kilometer, $\mathrm{GCK}=$ Grassy Creek kilometer; $\mathrm{SCK}=$ Scarboro Creek kilometer.

NS $=$ Not sampled. 
Table 6.10. Fish densities and biomass in Mitchell Branch and two reference streams, Grassy Creek and Scarboro Creek, for fall 1993

\begin{tabular}{|c|c|c|c|c|c|c|}
\hline \multirow[b]{3}{*}{ Species } & \multicolumn{6}{|c|}{$\begin{array}{c}\text { Density } \\
\text { (Biomass) }^{b}\end{array}$} \\
\hline & \multicolumn{6}{|c|}{ Sites $^{c}$} \\
\hline & $\begin{array}{r}\text { MIK } \\
0.45\end{array}$ & $\begin{array}{l}\text { MIK } \\
0.54\end{array}$ & $\begin{array}{r}\text { MIK } \\
0.71\end{array}$ & $\begin{array}{l}\text { MIK } \\
0.78\end{array}$ & $\begin{array}{c}\text { GCK } \\
2.4\end{array}$ & $\begin{array}{r}\mathrm{SCK} \\
2.2\end{array}$ \\
\hline Cyprinidae & & $\mathrm{NS}^{d}$ & & NS & NS & \\
\hline Central stoneroller & $\begin{array}{c}0.06 \\
(0.22)\end{array}$ & - & $\begin{array}{c}1.48 \\
(6.41)\end{array}$ & $\cdot$ & - & $\begin{array}{c}3.46 \\
(33.95)\end{array}$ \\
\hline Spotfin shiner & - & - & - & - & - & $\begin{array}{c}0.10 \\
(0.21)\end{array}$ \\
\hline Bluntnose minnow & - & - & - & - & - & $\begin{array}{c}1.88 \\
(3.28)\end{array}$ \\
\hline Fathead minnow & - & - & - & - & - & $\begin{array}{c}0.02 \\
(0.03)\end{array}$ \\
\hline Blacknose dace & $\begin{array}{c}3.18 \\
(2.85)\end{array}$ & - & $\begin{array}{c}2.00 \\
(1.82)\end{array}$ & - & - & $\begin{array}{c}0.38 \\
(2.69)\end{array}$ \\
\hline Creek chub & $\begin{array}{c}1.24 \\
(1.76)\end{array}$ & $\cdot$ & $\begin{array}{c}2.74 \\
(14.26)\end{array}$ & $\cdot$ & - & - \\
\hline \multicolumn{7}{|l|}{ Ictaluridae } \\
\hline Yellow bullhead & $\cdot$ & - & - & - & - & $\begin{array}{c}0.02 \\
(0.11)\end{array}$ \\
\hline \multicolumn{7}{|l|}{ Cottidae } \\
\hline Banded sculpin & - & - & - & - & - & $\begin{array}{c}0.68 \\
(2.41)\end{array}$ \\
\hline \multicolumn{7}{|l|}{ Centrarchidae } \\
\hline Redbreast sunfish & - & - & $\begin{array}{c}0.07 \\
(0.09)\end{array}$ & - & - & $\begin{array}{c}0.03 \\
(0.28)\end{array}$ \\
\hline Green sunfish & - & - & - & - & - & $\begin{array}{c}0.28 \\
(3.06)\end{array}$ \\
\hline Bluegill & - & $\cdot$ & - & - & - & $\begin{array}{c}0.69 \\
(2.27)\end{array}$ \\
\hline Largemouth bass & - & - & - & - & - & $\begin{array}{c}0.02 \\
(0.04) \\
\end{array}$ \\
\hline Number of species & 3 & NS & 4 & NS & NS & 11 \\
\hline Total density & 4.48 & & 6.29 & & & 7.56 \\
\hline Total biomass & 4.83 & & 22.58 & & & 48.33 \\
\hline
\end{tabular}

- ${ }^{a}$ Density expressed in number of individuals per square meter.

${ }^{b}$ Biomass, in parentheses, expressed in grams per square meter.

${ }^{\mathrm{M}} \mathrm{MIK}=$ Mitchell Branch kilometer, GCK $=$ Grassy Creek kilometer, $\mathrm{SCK}=$ Scarboro Creek kilometer.

${ }_{\mathrm{NS}}=$ Not sampled 
The variability in species number and composition in Mitchell Branch, Grassy Creek, and Scarboro Creek may be related to a combination of their proximity to Poplar Creek or Melton Hill Reservoir, impacts to Mitchell Branch by the K-25 Site facilities, and possible barriers in Mitchell Branch to upstream movement of fish. Grassy Creek is located approximately twice the distance from an embayment as either Mitchell Branch or Scarboro Creek and the dominant species, blacknose dace, creek chub, and banded sculpin, are common to small headwaters streams. The closeness of Scarboro Creek to Melton Hill Reservoir allows species to be found in Scarboro Creek when both are near impoundment waters that are atypical for streams of that size. The absence of fish species in Mitchell Branch compared with Scarboro Creek, when both are near impoundment waters, may be the result of adverse impacts to the stream. There has been an increase in the number of species present in Mitchell Branch since sampling began in September 1986 (Ryon 1993 and 1994b). The absence of northern hogsucker (Hypentelium nigricans) and yellow bullhead (Ameiurus natalis) in Mitchell Branch may reflect past extermination and the prevention of recolonization from Poplar Creek. The logperch (Percina caprodes) has been found at SCK 2.2 but not in Mitchell Branch. This is a species that can migrate from the embayments to the streams.

Fish have been absent or occurred in small numbers at MIKs $0.45,0.54$, and 0.78 from September/October 1986 through September 1990 (Ryon 1993 and 1994b). The presence of fish and the increase in species diversity at these sites through fall 1993 suggests improved water quality.

\subsubsection{Density and biomass}

Population surveys of Mitchell Branch and the two reference sites were conducted twice a year (spring and fall), and the data were used to estimate species density and biomass for each period. The total estimated density and biomass at each site for each sampling period are presented in Table 6.3. Values for individual species are given in Tables 6.4 through 6.10 .

. Total fish densities have exhibited similar trends throughout the sampling periods in Mitchell Branch. Total fish density within the four sampling sites was highest at MIK 0.78 for each sampling period from fall 1990 through fall 1992. Total density was highest at MIK 0.71 in 1993 (MIK 0.78 was not sampled). Total density was lower in the spring compared with fall at all sites. 
Total fish densities have increased at MIK 0.45 and MIK 0.71 from spring 1991 through spring 1993 and at MIK 0.54 and MIK 0.78 from spring 1991 to spring 1992. In contrast, density decreased from fall 1991 to fall 1992 at MIK 0.45 and MIK 0.54.

Total fish densities in Mitchell Branch were similar to values for the two reference sites. The total fish densities increased for each spring to spring and fall to fall period at the reference sites

The blacknose dace and the creek chub have been the dominant species in terms of density in Mitchell Branch throughout the sampling periods. Beginning in fall 1992, the central stoneroller greatly increased in density and was also a dominant species at MIKs 0.71 and 0.78. The central stoneroller was also one of the more abundant species present in Scarboro Creek but was absent in Grassy Creek.

In general, biomass in Mitchell Branch and the reference sites paralleled the trends observed in population densities. Biomass has generally increased at each site in Mitchell Branch between the spring sampling periods and between the fall sampling periods. Biomass has decreased at MIK 0.45 from fall 1991 through fall 1993 yet spring biomass has increased steadily throughout the same time period. Biomass also decreased slightly at MIK 0.54 from fall 1991 to fall 1992. The stoneroller became a dominant species in terms of biomass at MIK 0.71 in fall 1992.

\subsubsection{Length-frequency}

Length-frequency histograms represent the overall distribution of size classes of individuals within a population. The expected distribution would include a greater proportion of smaller individuals, with numbers decreasing as size increases. Length-frequency distributions can be used to demonstrate trends for a given species or trends among species at the same site. Length-frequency histograms were constructed for the most abundant species, blacknose dace, creek chub, and central stoneroller, collected in Mitchell Branch (Appendix G, Figs. G.1 through G.11) for the sampling periods of fall 1990 through fall 1993.

Length-frequency distributions were developed for the central stoneroller occurring in Mitchell Branch from fall 1992 through fall 1993 (Figs. G.1 through G.3). The central stoneroller was absent from fall 1990 through fall 1991 at three sites (MIKs 0.45, 0.54, and 0.71) sampled in Mitchell Branch. The central stoneroller was present in fall 1990 at MIK 0.78 but absent in 1991. The central stoneroller was represented by only a few 
individuals in fall 1992 and 1993 at MIK 0.45 and fall 1992 at MIK 0.54, but these do not represent stable populations (Fig. G.1). The central stoneroller was represented in 1992 at MIK 0.71 by a small number of individuals and was not indicative of a stable population at MIK 0.71 (Fig. G.2). The central stoneroller exhibited the expected length-frequency distribution of a normal population for spring and fall 1993 at MIK 0.71 .

The central stoneroller was represented by a few individuals in fall 1990 at MIK 0.78 (Fig. G.3). The central stoneroller was absent from this site in spring and fall 1991 and spring 1992. The central stoneroller population was represented by a large number of intermediate sized individuals in fall 1992.

Length-frequency histograms were developed for blacknose collected in Mitchell Branch from fall 1990 through fall. 1993 (Figs. G.4 through G.7). Blacknose dace exhibited the expected length-frequency distribution of a normal population for the fall 1991, 1992, and 1993 and spring 1993 sampling periods at MIK 0.45 (Fig. G.4). Blacknose dace were absent in fall 1990 and spring 1991 at MIK 0.45. Blacknose dace were present in low numbers at MIK 0.45 in spring 1992 but did not represent a normal population.

Blacknose dace exhibited the expected length-frequency distribution of a normal population for the fall 1991 and 1992 at MIK 0.54 (Fig. G.5). Blacknose dace were absent from MIK 0.54 in fall 1990 and spring 1991. Blacknose dace were present in low numbers at MIK 0.54 in spring 1992, but still had a length-frequency distribution of a normal population.

Blacknose dace exhibited the expected length-frequency distribution of a normal population for the fall 1991, 1992, and 1993 at MIK 0.71 (Fig. G.6). Blacknose dace were absent in fall 1990. Blacknose dace were present in low numbers at MIK 0.71 in spring 1991 but did not have a distribution of a normal population. Large numbers of the smaller size classes (3-3.9 and 4-4.9) of blacknose dace were lacking at MIK 0.71 in spring 1992 and 1993. This may indicate over winter mortality or emigration from the site.

Blacknose dace exhibited the expected length-frequency distribution of a normal population for fall 1990, 1991, and 1992, and spring 1991 at MIK 0.78 (Fig. G.7). The majority of the blacknose dace population in spring 1992 was represented by relatively equal numbers of fish in three length classes, 3-3.9, 4-4.9, and 5-5.9 cm and was not representative of a normal population.

The creek chub exhibited the expected length-frequency distribution of a normal population for fall 1991 and 1993 and spring 1993 at MIK 0.45 (Fig. G.8). Creek chub were 
absent at MIK 0.45 in fall 1990. The creek chub population in fall 1992 was represented by relatively equal numbers of fish in the 4-5.9 and 6-7.9 cm size class. The creek chub was present in low numbers at MIK 0.45 in spring 1991 and 1992.

The creek chub exhibited the expected length-frequency distribution of a normal population for fall 1991 and 1992 at MIK 0.54 (Fig. G.9). Fish were absent from MIK 0.54 in fall 1990. The creek was represented by a few individuals for both spring 1991 and 1992 and did not represent a stable population.

The creek chub exhibited the expected length-frequency distribution of a normal population for fall 1991, 1992, and 1993 at MIK 0.71. The creek chub was absent at MIK 0.71 in fall 1990 and represented by individuals in the intermediate size class in spring 1991 and 1992 (Fig. G.10). In spring 1993, the numbers of creek chub present at MIK 0.71 had increased substantially from spring 1992 but did not represent a normal population.

The creek chub exhibited the expected length-frequency distribution of a normal population for fall 1990, and spring and fall of 1991 and 1992 at MIK 0.78 (Fig. G.11).

\subsubsection{Annual production}

Annual production was calculated for spring 1990 to spring 1991, spring 1991 to spring 1992, and spring 1992 to spring 1993. Total production and production for selected species is given in Table 6.11.

In general, production increased each year for both individual species and the whole community at the four sites sampled in Mitchell Branch. Two exceptions were a slight decline in production of creek chub at MIK 0.71 and banded sculpin at MIK 0.78 in the 1991-1992 sampling period. Two other exceptions were that production of creek chub at MIK 0.54 and green sunfish at MIK 0.78 remained unchanged between sampling periods.

Total production of the four sampling sites in Mitchell Branch was greatest at MIK 0.78 for any given sampling period. Total production at MIK 0.78 was greater than at Grassy Creek for all periods. This was also the case for 1987 through 1990 (Ryon 1994b). Total production at MIKs 0.45 and 0.54 was much lower than at MIKs 0.78 or 0.71 . This may be due to stresses to the stream below the upstream locations.

Total production in Mitchell Branch was less than in Scarboro Creek for each sampling period. This may be due to the fact that Scarboro Creek contains many more species of fish, and biomass values were generally greater than at Mitchell Branch. 
Table 6.11. Annual production rates ${ }^{\circledR}$ of fish in Mitchell Branch, Grassy Creek, and Scarboro Creek from spring 1990 to spring 1993

\begin{tabular}{|c|c|c|c|c|c|c|c|}
\hline \multirow[b]{2}{*}{ Species } & \multirow[b]{2}{*}{$\begin{array}{l}\text { Production } \\
\text { period }\end{array}$} & \multicolumn{6}{|c|}{ Sites $^{b}$} \\
\hline & & MIK 0.45 & MIK 0.54 & MIK 0.71 & MIK 0.78 & GCK 2.4 & SCK 2.2 \\
\hline Central stoneroller & $\begin{array}{l}1990-1991 \\
1991-1992 \\
1992-1993\end{array}$ & & & $\begin{array}{l}0.00 \pm 0.00 \\
-0.15 \\
1.29\end{array}$ & $\begin{array}{r}-0.10 \pm 0.03 \\
0.00 \pm 0.00\end{array}$ & & $\begin{array}{l}1.85 \\
18.22\end{array}$ \\
\hline $\begin{array}{l}\text { Blacknose } \\
\text { dace }\end{array}$ & $\begin{array}{l}1990-1991 \\
1991-1992 \\
1992-1993\end{array}$ & $\begin{array}{l}0.00 \pm 0.00 \\
0.11 \pm 0.04 \\
2.34 \pm 0.10\end{array}$ & $\begin{array}{l}0.00 \pm 0.00 \\
0.18\end{array}$ & $\begin{array}{l}-0.09 \pm 0.04 \\
2.21 \\
3.34\end{array}$ & $\begin{array}{l}1.40 \pm 0.10 \\
2.30 \pm 0.14\end{array}$ & $\begin{array}{l}0.48 \pm 0.07 \\
0.28\end{array}$ & $\begin{array}{l}0.74 \pm 0.09 \\
0.06 \pm 0.11\end{array}$ \\
\hline Creek chub & $\begin{array}{l}1990-1991 \\
1991-1992 \\
1992-1993\end{array}$ & $\begin{array}{r}-0.02 \pm 0.01 \\
-0.15 \pm 0.04 \\
0.84 \pm 0.07\end{array}$ & $\begin{array}{l}-0.05 \\
-0.05\end{array}$ & $\begin{array}{l}0.36 \\
0.19 \pm 0.07 \\
4.90 \pm 0.23\end{array}$ & $\begin{array}{l}2.74 \pm 0.47 \\
4.32 \pm 0.40\end{array}$ & $\begin{array}{l}0.62 \\
0.47\end{array}$ & $\begin{array}{l}-0.01 \\
-0.04\end{array}$ \\
\hline Banded sculpin & $\begin{array}{l}1990-1991 \\
1991-1992 \\
1992-1993\end{array}$ & & & & $\begin{array}{r}0.00 \pm 0.00 \\
-0.06 \pm 0.03\end{array}$ & $\begin{array}{l}-0.16 \pm 0.03 \\
-0.05 \pm 0.02\end{array}$ & $\begin{array}{l}2.80 \pm 0.19 \\
1.48 \pm 0.17\end{array}$ \\
\hline Green sunfish & $\begin{array}{l}1990-1991 \\
1991-1992 \\
1992-1993\end{array}$ & & & & $\begin{array}{l}-0.12 \pm 0.01 \\
-0.12 \pm 0.01\end{array}$ & & $\begin{array}{l}0.99 \pm 0.08 \\
1.13 \pm 0.15\end{array}$ \\
\hline Total $^{c}$ & $\begin{array}{l}1990-1991 \\
1991-1992 \\
1992-1993\end{array}$ & $\begin{array}{r}-0.02 \\
-0.10 \\
3.12\end{array}$ & $\begin{array}{r}-0.05 \\
0.13\end{array}$ & $\begin{array}{l}0.27 \\
2.25 \\
9.41\end{array}$ & $\begin{array}{l}3.91 \\
6.37\end{array}$ & $\begin{array}{l}0.83 \\
0.67\end{array}$ & $\begin{array}{l}5.81 \\
20.23\end{array}$ \\
\hline
\end{tabular}

${ }^{a}$ Measured in grams, wet weight, per square meter per year, $\pm S E$.

${ }^{b}$ MIK = Mitchell Branch kilometer; $\mathrm{GCK}=$ Grassy Creek kilometer; $\mathrm{SCK}=$ Scarboro Creek kilometer.

${ }^{c}$ Totals include miscellaneous species (striped shiner, redbreast sunfish, white sucker, bluntnose minnow, yellow bullhead, northern hogsucker, bluegill and logperch) not listed in table. 
Annual production at MIK 0.71 and MIK 0.78 was similar to values for other streams on the ORR (Table 5.5 in Ryon 1994a). Annual production values at MIK 0.45 and MIK 0.54 were generally less than those in other streams on the ORR.

\subsubsection{Fish kills}

From June 1990 through December 1993, two fish kills were reported in Mitchell Branch. On November 5, 1990, dead fish were reported in Mitchell Branch downstream of the railroad crossing. Surveys were initiated from the railroad bridge crossing downstream to the confluence with Poplar Creek. A total of 21 surveys were conducted from November 5, 1990, through December 26, 1990. Dead fish were found on the first ten surveys conducted. A total of 12 creek chub, 2 western mosquitofish (Gambusia affinis), 227 redbreast sunfish, 7 unidentified sunfish, 1 salamander, and 1 crayfish were found dead during the surveys. No cause for the fish kill was determined.

The second fish kill was reported on August 31, 1992. Four surveys were made from August 31, 1992, through September 3, 1992. One dead of each of the following were found on the initial survey: creek chub, blacknose dace, and crayfish. This appeared to be a rather small isolated kill. No cause for the kill was determined.

\subsubsection{Conclusions}

Data on the fish populations in Mitchell Branch have demonstrated that the stream has received stress from K-25 plant operations discharges in the past. Mitchell Branch had more species of fish compared with the reference stream, Grassy Creek, but was also missing common fish species found in Scarboro Creek and other area streams. The lack of these species may have been caused by past extermination and the prevention of recolonization from Poplar Creek and possibly by continued disturbances to the stream.

Fish population data from Mitchell Branch have suggested that improvements in water quality have occurred. There has been an increase in the number of fish species present in the fall 1990 through fall 1993 period compared with earlier years. In general, total fish density, biomass, and annual production values have increased in Mitchell Branch. Length-frequency distributions appear to have more stable populations of fish in Mitchell Branch in 1993 in comparison with earlier years. Continued remedial actions and a decrease in perturbations to 
the stream may allow for more species to colonize the stream and populations to become more stabilized.

\subsubsection{Future Studies}

- Routine, quantitative monitoring of fish density, biomass, richness, and population size structure will be conducted twice annually (spring and fall) at MIKs 0.45 and 0.71 .

Because immigration into Mitchell Branch from Poplar Creek is occurring, further qualitative sampling will be conducted to assess immigration. This sampling may be a cooperative effort with sampling for the bioaccumulation task. 


\section{SUMMARY OF STREAM HEALTH \\ L. A. Kszos and R. L. Hinzman}

One of the goals of the K-25 Site BMAP is to determine whether new pollution abatement facilities and other remedial actions have had an effect on the aquatic biota of Mitchell Branch. Table 2.2 lists some of the K-25 Site activities that probably had a positive impact on water quality in Mitchell Branch. In addition, the end of the drought in 1988 was a significant natural phenomena that influenced the results of the biological monitoring. The number and timing of both remedial activities and natural events makes it difficult to associate any one activity with a specific biological response; toxicity monitoring is the only method capable of detecting changes in water quality immediately following an abatement activity. The difficulty in discriminating the effects of single events highlights the need for long-term monitoring. Using this approach, the K-25 Site BMAP has documented the positive results of some abatement activities in nearly every task. The BMAP also shows that although improvements have been documented, the biota in Mitchell Branch remain impacted.

Ecological improvement or recovery has been documented in the toxicity monitoring and instream monitoring tasks. The K-25 Site has successfully eliminated the acute toxicity of water from Mitchell Branch to fathead minnows and Ceriodaphnia in laboratory tests. In 1990, water from MIK 0.71 downstream to MIK 0.45 was acutely toxic. In 1991, 1992, and 1993, no acute toxicity was observed. However, the results of both the Mitchell Branch and storm drain toxicity tests indicate that the effluent from SD 170 and SD 190 continues to adversely impact biota.

Likewise, instream monitoring of the benthic macroinvertebrate and fish communities has demonstrated recovery of these communities since 1989. Recovery of the benthic macroinvertebrate populations occurred after October 1989 from MIK 0.78 downstream to MIK 0.45 with the greatest recovery occurring at MIK 0.45 and MIK 0.54 . These changes generally coincided with improvements in water quality, as documented by ambient toxicity tests conducted after 1988. In 1990, the appearance of pollution-intolerant groups of aquatic insects (e.g., mayflies and stoneflies) downstream of MIK 0.78 indicated improved conditions. Although conditions have improved, the most recent data (April 1993) indicate that the benthic 
macroinvertebrate community remains impacted, as documented by a depression of total and EPT richness and substantial fluctuations in density, total richness, and EPT richness.

Similar changes have also been noted in the fish community of Mitchell Branch. Prior to fall 1990, fish were virtually absent from MIK 0.78 downstream to MIK 0.45 . In spring 1990, the presence of fish from MIK 0.78 downstream to MIK 0.45 indicated improved conditions. Since 1991, three species that had not previously been collected were found at MKK 0.71 and MIK 0.78 , and there has been a general increase in fish density, biomass, and annual production from MIK 0.78 downstream to MIK 0.45. In 1993, the length-frequency distributions of fish were indicative of a more stable population compared with earlier years. Similar to the benthic macroinvertebrate results, the fish data show there has been recovery, but the communities differ from those in the reference streams and are indicative of degraded water quality.

Two BMAP tasks have documented only slight improvement or no change in status. The assessment of fish health, which uses an integrated approach to investigate the holistic responses of fish to environmental stressors, showed a decrease in fish health from 1989 to 1991 but some improvement in 1992. The increase in growth and change in size distribution of the redbreast sunfish population at MIK 0.12 since 1990 is a documented improvement. Although there are indications of improvement, the integrated health responses of the Mitchell Branch fish remain dissimilar from the health responses of reference fish. This dissimilarity suggests that the Mitchell Branch population, although healthier in 1992 than in previous years, remains stressed. Based on measures of reproductive health, the sunfish collected in spring 1993 from Mitchell Branch were clearly different from reference site fish. Toxicity tests with medaka indicated that Mitchell Branch is often toxic to embryos.

The bioaccumulation of contaminants in aquatic biota has not changed over the past several years. Levels of mercury and PCBs have remained stable in sunfish from 1990 to 1993. Some fish in Mitchell Branch have had PCB concentrations that exceed the FDA tolerance limit of $2 \mu \mathrm{g} / \mathrm{g}$. The results of mercury and PCB monitoring of fish prior to 1992 did not show clearly whether or not Mitchell Branch was a source of PCBs or mercury. Evidence collected in 1992 from caged and resident fish suggests that the source of mercury contamination in Mitchell Branch fish arises from a source within that watershed.

While BMAP has demonstrated that improvements have occurred in water quality at the K-25 Site, it has also shown that aquatic communities and the health of fish in Mitchell 
Branch are dissimilar from reference sites. Moreover, the BMAP tasks document that the water quality of Mitchell Branch does not fully support the growth and propagation of fish and other aquatic life, a classified use of the stream. The K-25 Site has addressed many pollution sources (e.g., the removal of chlorinated discharges); and, with additional abatement actions, further ecological recovery is expected. The challenge now is to use BMAP to identify those additional sources of impact to biota and then develop appropriate remedial actions. 


\section{REFERENCES}

Adams, S. M. 1990. Biological indicators of stress in fish. Amer. Fish. Soc. Sym. No. 8, - Amer. Fish. Soc., Bethesda, MD.

Adams, S. M., W. D. Crumby, M. S. Greeley, and L. R. Shugart. 1992a. Responses of fish populations and communities to pulp mill effluents: a holistic assessment. Ecotoxicol. Environ. Saf. 24:347-360.

Adams, S. M., W. Dennis Crumby, M. S. Greeley, M. G. Ryon, and E. M. Schilling. 1992 b. Relationships between physiological and fish population responses in a contaminated stream. 11:1549-1557.

Adams, S. M. and M.G. Ryon. (In Press). Comparison of health assessment approaches for evaluating the effects of contaminant-related stress on fish populations. J. Aquatic Ecosystem Health.

Adams, S. M. 1994. Biological indicators of contaminant related stress. IN J. M. Loar, (ed.), Fourth report on the Oak Ridge National Laboratory Biological Monitoring and Abatement Program for White Oak Creek watershed and the Clinch River. ORNL/TM11544. Oak Ridge National Laboratory, Oak Ridge, Tenn.

Adams, S. M., W. D. Crumby, M. S. Greeley, Jr., and L. R. Shugart. 1992. Responses of fish populations and communities to pulp mill effluents: a holistic assesssment. Ecotoxicol. Environ. Safety 24:347-360.

Adams, S. M., and R. B. McLean. 1985. Estimation of largemouth bass, Micropterus salmoides Lacepede, growth using the liver somatic index and physiological variables. J. Fish Biol. 26:111-126.

Addison, R. F. 1984. Hepatic mixed function oxidase (MFO) induction in fish as a possible biological monitoring system. pp. 51-60. IN V. W. Cairns, P. V. Hodson, and

- J. O. Nriagu (eds.), Contaminant Effects on Fisheries. John Wiley \& Sons, New York. Aho, J. M., C. S. Anderson, and J. W. Terrell. 1986. Habitat suitability index models and instream flow suitability curves: redbreast sunfish. U.S. Fish Wildl. Serv. Biol. Rep. 82(10.119). $23 \mathrm{pp}$. 
Ahokas, J. T., N. T. Kärki, A. Oikari, and A. Soivio. 1976. Mixed function monooxygenase of fish as an indicator of pollution of Aquatic Environment by industrial effluent. Bull. Environ. Contam. Toxicol. 16:270-274.

Allain, C. C., L. S. Poon, C. S. G. Chan, W. Richmond, and P. C. Fu. 1974. Enzymatic determination of total serum cholesterol. Clin. Chem. 20:470-475.

Anderson, R. O., and S. J. Gutreuter. 1983. Length, weight, and associated structural indices. IN L. A. Nielsen and D. L. Johnson (eds.), Fisheries Techniques. American Fisheries Society, Bethesda, Maryland. 468 pp.

Ashwood, T. L., C. R. Olsen, I. L. Larsen, and P. D. Lowery. 1986. Sediment contamination in streams surrounding the Oak Ridge Gaseous Diffusion Plant. ORNL/TM-9791. Oak Ridge National Laboratory, Oak Ridge, Tenn.

Bagenal, T. B. 1978. Methods for assessment of fish production in fresh waters. Blackwell Scientific Publications. Oxford.

Bennett, G. W. 1970. Management of lakes and ponds. Van Nostrand Reinhold Company, New York.

Bergmeyer, H. U., P. Scheibe, and A. W. Wahlefeld. 1978. Optimization of methods for aspartate amino-transferase and alanine amino-transferase. Clin. Chem. 24:58-73.

Bigler, W. J., J. H. Jenkins, P. M. Cumbie, G. L. Hoff, and E. C. Prather. 1975. Wildlife and environmental health: Raccoons as indicators of zoonoses and pollutants in the Southeastern United States. JAVMA 167:592-97.

Bloom, N. S. 1992. On the chemical form of mercury in in edible fish and marine invertebrate tissue. Cán. J. Fish. Aquat. Sci. 49:1010-1017.

Boyle, J. W., R. Blumberg, S. J. Cotter, G. S. Hill, C. R. Kerley, R. H. Ketelle, R. L. Kroodsma, D. W. Lee, R. C. Martin, R. D. Roop, D. N. Secora, W. P. Staub, and R. E. Thoma. 1982. Environmental analysis of the operation of the Oak Ridge National Laboratory (X-10 Site). ORNL-5870. Oak Ridge National Laboratory, Oak Ridge, Tenn.

Bradford, M. M. 1976. A rapid and sensitive method for the quantitation of protein utilizing the principle of protein-dye binding. Anal. Biochem. 72:248-254.

Bowen, H. J. M. 1979. Environmental Chemistry of the Elements. Acedemic Press. N.Y. 333 pp.

Brown, D. A., R. W. Gossett, G. P. Hershelman, C. F. Ward, A. M. Westcott, and J. N. Cross. 1986. Municipal wastewater contamination in the Southern California Bight: 
Part I-Metal and organic contami-nants in sediments and organisms. Mar. Environ. Res. 18:291-310.

Bucolo, G., and H. David. 1973. Quantitative determination of serum triglycerides by the use of enzymes. Clin. Chem. 19:476-482.

Burke, M. D., and R. T. Mayer. 1974. Ethoxyresorufin: Direct fluorimetric assay of a microsomal O-dealkylation which is preferentially inducible by 3 -methylcholanthrene. Drug Metab. Dispos. 2:583-588.

Cairns, J. and W. H. van der Schalie. 1980. Biological monitoring, Part I-Early warning systems. Water Res. 14:1179-1196.

Capuzzo, J. M. 1985. Biological effects of petroleum hydrocarbons on marine organisms: Integration of experimental results and predictions of impacts. Mar. Environ. Res. $17: 272-276$.

Carlander, K. D. 1982. Standard intercepts for calculating lengths from scale measurements for some centrarchid and percid fishes. Trans. Amer. Fish. Soc. 111:332-336.

Carle, F. L., and M. R. Strub. 1978. A new method for estimating population size from removal data. Biometrics 34:621-630.

Conover, W. J. 1980. Practical nonparametric statistics, Second edition. John Wiley and Sons, New York, NY.

Cook, R. B., S. M. Adams, J. J. Beauchamp, M. S. Bevelhimer, B. G. Blaylock, C. C. Brandt, E. L. Etnier, C. J. Ford, M. L. Frank, M. J. Gentry, M. S. Greeley, R. S. Halbrook, R. A. Harris, S. K. Holladay, L. A. Hook, P. L. Howell, L. A. Kszos, R. F. LeHew, D. A. Levine, K. Murray, T. L. Phipps, J. L. Skiles, G. W. Suter. 1993. Phase 2 sampling and analysis plan, quality assurance project plan, and health and safety plan for the Clinch River remedial investigation: An addendum to the Clinch River RCRA facility investigation plan. DOE/OR/01-1111 \& D3. Oak Ridge National Laboratory, Oak Ridge, Tenn.

Cumbie, P. H. 1975. Mercury in the hair of bobcats and raccoons. J. Wildl. Manage. 39:419-25.

Daniel, W. W. 1987. Biostatistics: A Foundation for Analysis in the Health Sciences, 4th ed. John Wiley and Sons, New York. 
Davis, J. R. 1972. The spawning behavior, fecundity rates, and food habits of the redbreast sunfish in southeastern North Carolina. Proc. Annu. Conf. Southeast. Assoc. Game Fish Comm. 25:556-560.

DOE (U.S. Department of Energy). 1979. Environmental assessment of the Oak Ridge Gaseous Diffusion Plant site. DOE/EA-0106. Technical Information Center, U.S. Department of Energy, Oak Ridge, Tenn.

Doumas, B. T., W. A. Watson, and H. G. Biggs. 1972. Standard methods in clinical chemistry. Clin. Chem. Acta. 31:87.

Elliott, J. M. 1977. Some methods for the statistical analysis of samples of benthic invertebrates. Freshwater Biological Association, Ambleside, England. Sci. Pub. No. 25.

Elwood, J. W., J. D. Newbold, A. F. Trimble, and R. W. Stark. 1981. The limiting role of phosphorus in a woodland stream ecosystem: Effects of $P$ enrichment on leaf decomposition and primary producers. Ecology 62:146-156.

EPA (U.S. Environmental Protection Agency). 1980. Interim methods for the sampling and analysis of priority pollutants in sediments and fish tissues. EPA 600/4-81-055. U.S. Environmental Protection Agency, Environmental Monitoring and Support Laboratory, Cincinnati, Oh.

EPA (U.S. Environmental Protection Agency). 1983. Extraction and analysis of priority pollutants in biological tissue, Method PPD 12/83. U.S. Environmental Protection Agency, Environmental Sciences Division, Region IV, Analytical Support Branch, Athens, Ga. Mimeo.

EPA (U.S. Environmental Protection Agency). 1984. Extraction and analysis of priority pollutants in biological tissue, method PPB 12/83. EPA 600/4-81-055. Environmental Services Division, Region IV, U.S. Environmental Protection Agency, Athens, Georgia. Mimeo.

EPA (U.S. Environmental Protection Agency). 1986a. Authorization to discharge under the National Pollutant Discharge Elimination System, Permit No. TN0002950, Oak Ridge Gaseous Diffusion Plant. U.S. Environmental Protection Agency, Region IV, Atlanta, Ga.

EPA (U.S. Environmental Protection Agency). 1986b. Quality Criteria for Water. Office of Water Regulations and Standards, Washington, D.C. 
EPA (U.S. Environmental Protection Agency). 1990. Toxic substance spreadsheet.

U.S. Environmental Protection Agency, Region IV, Water Management Division, Atlanta, Ga. Mimeo.

EPA (U.S. Environmental Protection Agency). 1991. Methods for the Determination of Metals in Environmental Samples. EPA-600/4-91-010. Environmental Monitoring Systems Laboratory, U.S. Environmental Protection Agency, Cincinnati, Ohio.

EPA (U.S. Environmental Protection Agency). 1993. Guidance for assessing chemical contaminant data for use in fish advisories. Vol. 1. Fish sampling and analyses. Office of Science and Technology, Office of Water, U.S. Environmental Protection Agency, Washington D.C.

Everhart, W. H., A. W. Eipper, and D. W. Youngs. 1975. Principles of Fishery Science. Cornell University Press, Ithaca, N.Y.

Fausch, K. D., J. Lyons, J. R. Karr, and P. L. Angermeier. 1990. Fish communities as indicators of environmental degradation. Am. Fish. Soc. Symp. 8:123-144.

Fletcher, G. L, M. J. King, J. W. Kiceniuk, and R. F. Addison. 1982. Liver hypertrophy in winter flounder following exposure to experimentally oiled sediments. Comp. Biochem. Physiol. 73C:45762.

FDA (U.S. Department of Agriculture Food and Drug Administration). 1984a. Polychlorinated biphenyls (PCBs) in fish and shellfish: Reduction of tolerances, Final Decision. Fed. Regist. 49(100):21520.

FDA (U.S. Department of Agirculture Food and Drug Administration). 1984b. Action level for methylmercury in fish. Fed. Regist. 49(224):456-463.

Forlin, L., and T. Anderson. 1985. Storage conditions of rainbow trout liver cytochrome P450 and conjugating enzymes. Comp. Biochem. Physiol. 3:569-572.

Fraser, C. M. 1916. Growth of the spring salmon. Trans. Pacific Fish. Soc. 1915:29-39.

Freeman, B. J., and M. C. Freeman. 1985. Production of fishes in a subtropical blackwater ecosystem: The Okefenokee swamp. Limnol. Oceanogr. 30:686-692.

Garman, G. C., and T. F. Waters. 1983. Use of the size-frequency (Hynes) method to estimate annual production of a stream fish population. Can. J. Fish. Aquat. Sci. 40:2030-2034. 
Greeley, M. S., Jr., R. MacGregor III, and K. R. Marion. 1988. Variation in plasma oestrogens and androgens during the seasonal and semilunar spawning cycles of female gulf killifish, Fundulus grandis (Baird and Girard). 33: 419-429.

Greeson, P. E., T. A. Ehlke, G. A. Irwin, B. W. Lium, and K. V. Slack. 1977. Methods for collection and analysis of aquatic biological and microbiological samples. Book 5, Chap. 4A, pp. 1-332. IN U.S. Geological Survey, Techniques of water-resources Investigations of the United States Geological Survey. U.S. Government Printing Office, Washington, D.C.

Heath, A. G. 1987. Water pollution and fish physiology. CRC Press, Boca Raton, Fla. Heidinger, R. C., and S. D. Crawford. 1977. Effect of temperature and feeding rate on the liver-somatic index of the largemouth bass, Micropterus salmoides. J. Fish. Res. Bd. Can. 34:633-638.

Henry, R. J., D. C. Cannon, and J. W. Winkelman. 1974. Clinical chemistry; principles and technics. 2nd ed. Harper and Row, Hagerstown, Md.

Herbert, G. B. and T. J. Peterle. 1990. Heavy metal and organochlorine compund concentrations in tissues of raccoons from east-central Michigan. Bull. Environm. Contam. Toxicol. 44:331-38.

Hile, R. 1936. Age and growth of the cisco, Leucichthys artedi (LeSeur), in the lakes of the northeastern high-lands, Wisconsin. U.S. Bur. Fish. Bull. 48:211-317.

Hinton, D. E., and J. A. Couch. 1984. Pathological measures of marine pollution effects. pp. 7-32. IN H. H. Harris (ed.), Concepts in Marine Pollution Measurements. Maryland Sea Grant College, University of Maryland, College Park, Md.

Hinzman, R. L., S. M. Adams, M. C. Black, H. L. Boston, W. Burton, A. J. Gatz, Jr., M. S. Greeley, Jr., W. R. Hill, J. M. Loar, J. F. McCarthy, M. J. Peterson, M. G. Ryon, J. G. Smith, G. R. Southworth, A. J. Stewart, and V. R. Tolbert. 1993. Second report on the Oak Ridge Y-12 Plant Biological Monitoring and Abatement Program for East Fork Poplar Creek. Y/TS-888. Oak Ridge National Laboratory, Oak Ridge, Tenn.

Hinzman, R. L. 1994. Third Report on the Y-12 Plant Biological Monitoring and Abatement Program for East Fork Poplar Creek. Draft ORNL/TM. Oak Ridge National Laboratory, Oak Ridge, Tenn.

Hoff, G. L., W. J. Bigler, and J. G. McKinnon. 1977. Heavy metal concentrations in kidneys of estuarine raccoons from Florida. J. Wildl. Dis. 13:101-02. 
Hoffman, F. O., B. G. Blaylock, C. C. Travis, K. L. Daniels, E. L. Etnier, K. E. Cowser, and C. W. Weber. 1984. Preliminary screening of contaminants in sediments. ORNL/TM-9730. Oak Ridge National Laboratory, Oak Ridge, Tenn.

Horning, W. B., and C. I. Weber 1985. Short-term methods for estimating the chronic toxicity of effluents and receiving waters to freshwater organisms. EPA/600/4-85/014.

U.S. Environmental Protection Agency, Cincinnati, Oh.

Horowitz, R. J. 1978. Temporal variability patterns and the distributional patterns of stream fishes. Ecol. Monog. 48:307-321.

Huckabee, J. W., J. W. Elwood, and S. G. Hildebrand. 1979. The biogeochemistry of mercury in the environment. Elsevier/North Holland Biomedical Press, N.Y. p.277.

Hynes, H. B. N. 1960. The Biology of Polluted Waters. Liverpool University Press.

Hynes, H. B. N. 1970. The Ecology of Running Waters. University of Toronto Press.

Jearld, A. 1983. Age determination. pp. 301-324. IN L. A. Nielsen and D. L. Johnson (eds.), Fisheries Techniques. Southern Printing Co., Blacksburg, Va.

Johannesen, K. M., and J. W. DePierre. 1978. Measurements of cytochrome $P_{450}$ in the presence of large amounts of contaminating hemoglobin and methemoglobin. Anal. Biochem. 86:725-32.

Johnson, L. L., E. Casillas, T. K. Collier, B. B. McCain, and U. Varanasi. 1988. Contaminant effects on ovarian development in English Sole (Parophrys vetulus) from Puget Sound, Washington. Can. J. Fish. Aquat. Sci. 45: 2133-2146.

Johnson, R. A. and D. W. Wichern. 1992. Applied Multivariate Analysis, Third Edition. Prentice Hall, Inc., Englewood Cliff, NJ.

Karr, J. R. 1981. Assessment of biotic integrity using fish communities. Fisheries 6:21-27.

Karr, J. R. 1987. Biological monitoring and assessment: A conceptual framework. Environ. Manag. 11:249-256.

Karr, J. R. 1991. Biological integrity: A long-neglected aspect of water resource management. Ecol. Appl. 1:165-184.

Karr, J. R., K. D. Fausch, P. L. Angermeier, P. R. Yant, and I. J. Schlosser. 1986. Assessing biological integrity in running waters: A method and its rationale. Illinois Natural History Survey Special Publication 5. 
Kasten, J. L. 1986. Resource Management Plan for the Oak Ridge Reservation, Vol. 21: Water Conservation Plan for the Oak Ridge Reservation. ORNL/ESH-1/V21. Oak Ridge National Laboratory, Oak Ridge, Tenn.

Knuth, M. L. 1979. The incidence of polychlorinated biphenyls and other chlorinated hydrocarbons in raccoon adipose tissue and selected aquatic organisms in the central Wisconsin River basin. M.S. Thesis. University of Wisconsin, Stevens Point.

Kornegay, F. C. 1993. Oak Ridge Reservation Environmental Report for 1992. Volume 1: Narrative. K/EM-24/R2. Oak Ridge, Tenn.

Krarup, T. 1969. Oocyte destruction and ovarian tumorigenesis after direct application of a chemical carcinogen (9:10-dimethyl-1:2-benzanthracene) to the mouse ovary. Int. J. Cancer 4: 61-75.

Kszos, L. A. and A. J. Stewart. 1992. Artifacts in ambient toxicity testing. Proceedings of the Water Environment Federation, $65^{\text {th }}$ Annual Conference and Exposition, New Orleans, Lousiana, September 20-24, 1992 (Paper AC92-020-005).

Kszos, L. A. 1993. Toxicity monitoring. IN J. G. Smith et al., First Report on the Oak Ridge K-25 Site Biological Monitoring and Abatement Program for Mitchell Branch. ORNL/TM-1 1073. Oak Ridge National Laboratory, Oak Ridge, Tenn.

Kszos, L. A. 1994. Toxicity monitoring. IN J. G. Smith et al., Second Report on the Oak Ridge K-25 Site Biological Monitoring and Abatement Program for Mitchell Branch. ORNL/TM-12150. Oak Ridge National Laboratory, Oak Ridge, Tenn.

Kszos, L. A., A. J. Stewart, L. F. Wicker, L. E. Roberson, and T. L. Phipps. 1989. Environmental Sciences Division Toxicology Laboratory Quality Assurance Program. QAP-X-89-ES-002. Oak Ridge National Laboratory, Oak Ridge, Tenn.

Kszos, L. A., A. J. Stewart, and P. A. Taylor. 1992. An evaluation of nickel toxicity to Ceriodaphnia dubia and Daphnia magna in a contaminated stream and in laboratory tests. Environ. Toxicol. Chem 11:1001-1012.

Kszos, L. A., A. J. Stewart, L. F. Wicker, and G. M. Logsdon. 1988. Environmental Sciences Division Toxicology Laboratory Standard Operating Procedures. ORNL/TM-11194. Oak Ridge National Laboratory, Oak Ridge, Tenn.

Layher, W. G., L. B. Fox, and R. Broxterman. 1987. Environmental contaminants in raccoons in Kansas. Bull. Environ. Contam. Toxicol. 39:926-32. 
Lee, R. M. 1920. A review of the methods of age and growth determination in fishes by means of scales. Fishery Investigations, Series II, Marine Fisheries Great Britain Ministry of Agriculture and Fisheries and Food. 4(2):1-32.

Loar, J. M., F. A. Burkhart, G. F. Cada, J. W. Huckabee, J. T. Kitchings, K. D. Kumar, A. M. Sasson, J. A. Solomon, and J. D. Story. 1981. Ecological studies in the vicinity of the Oak Ridge Gaseous Diffusion Plant. ORNL/TM-6714. Oak Ridge National Laboratory, Oak Ridge, Tenn.

Loar, J. M., M. J. Sale, G. F. Cada, D. K. Cox, R. M. Cushman, G. K. Eddlemon, J. L. Elmore, A. J. Gatz, Jr., P. Kanciruk, J. A. Solomon, and D. S. Vaughn. 1985. Application of habitat evaluation models in southern Appalachian trout streams. ORNL/TM-9323. Oak Ridge National Laboratory, Oak Ridge, Tenn.

Loar, J. M., J. M. Giddings, S. M. Adams, J. F. McCarthy, and G. R. Southworth. 1989. The Oak Ridge Y-12 Plant Biological Monitoring and Abatement Program for East Fork Poplar Creek. TM-10265. Oak Ridge National Laboratory, Oak Ridge, Tennessee.

Loar, J. M., S. M. Adams, B. G. Blaylock, H. L. Boston, M. A. Huston, B. L. Kimmel, C. R. Olsen, J. G. Smith, G. R. Southworth, A. J. Stewart, and B. T. Walton. 1991a. Oak Ridge National Laboratory Biological Monitoring and Abatement Program for White Oak Creek watershed and the Clinch River. ORNL/TM-10370. Oak Ridge National Laboratory, Oak Ridge, Tenn.

Loar, J. M., L. M. Adams, S. M. Adams, M. G. Ryon, J. G. Smith, G. R. Southworth, and A. J. Stewart. 1992a. Oak Ridge Gaseous Diffusion Plant Biological Monitoring and Abatement Program for Mitchell Branch. ORNL/TM-11965. Oak Ridge National Laboratory, Oak Ridge, Tenn.

Loar, J. M., S. M. Adams, L. J. Allison, M. C. Black, H. L. Boston, A. J. Gatz, Jr., R. L. Hinzman, M. A. Huston, B. D. Jimenez, J. F. McCarthy, S. D. Reagan, J. G. Smith, G. R. Southworth, A. J. Stewart. 1992b. First Report on the Oak Ridge Y-12 Plant Biological Monitoring and Abatement Program for East Fork Poplar Creek. Y/TS-886. Oak Ridge Y-12 Plant, Oak Ridge, Tenn.

Loar, J. M., S. M. Adams, R. D. Bailey, B. G. Blaylock, H. L. Boston, W. R. Hill, M. A. Huston, B. D. Jimenez, L. Meyers-Schöne, D. A. Mohrbacher, M. J. Peterson, M. G. Ryon, K. L. Shepard, L. R. Shugart, J. G. Smith, G. R. Southworth, A. J. Stewart, C. K. Valentine, B. T. Walton, and A. E. Waters. 1994: Third report on the Oak Ridge 
National Laboratory Biological Monitoring and Abatement Program for White Oak Creek watershed and the Clinch River. ORNL/TM-11358. Oak Ridge National Laboratory, Oak Ridge, Tenn.

Lotrich, V. A. 1973. Growth, production, and community composition of fishes inhabiting a first-, second-, and third-order stream of eastern Kentucky. Ecol. Monogr. 43:377-397. Lowe, T. P., T. W. May, W. G. Brumbaugh, and D. A. Kane. 1985. National contaminant biomonitoring program: Concentrations of seven elements in freshwater fish, 1978-1981. Arch. Environ. Contam. Toxicol. 14:373-388.

Lowery, J. F., P. H. Counts, H. L. Edmiston, and F. D. Edwards. 1987. Water resources data for Tennessee, Water Year 1986. Report No. USGS/WRD/HD-87/225. U.S. Geological Survey, Nashville, Tenn.

Martin Marietta Energy Systems, Inc. 1983. Environmental and effluent analysis manual. Martin Marietta Energy Systems, Inc., Oak Ridge, Tenn.

Mattison, D. R., K. Shiromizu, and M. S. Nightingale. 1983. Oocyte destruction by polycyclic aromatic hydrocarbons. Am. J. Ind. Med. 4: 191-202.

McCormick, J. H., K. M. Jensen, R. L. Leino, and G. N. Stokes. 1987. Fish blood osmolality, gill histology, and oocyte atresia as early warning acid stress indicators. Annls. Soc. R. Zool. Belg. 117 (suppl. 1): 309-319.

McElravy, E. P., G. A. Lamberti, and V. H. Resh. 1989. Year-to-year variation in the aquatic macroinvertebrate fauna of a northern California stream. J. N. Am. Benthol. Soc. $8: 51-63$.

McGaha, M. A. 1989a. Toxicity monitoring at ORGDP July-September 1988. K/QT-288. Oak Ridge Gaseous Diffusion Plant, Oak Ridge, Tenn.

McGaha, M. A. 1989b. Toxicity monitoring at ORGDP October-December 1988. K/QT-0311. Oak Ridge Gaseous Diffusion Plant, Oak Ridge, Tenn.

McGaha, M. A. 1989c. Toxicity monitoring at ORGDP January-March 1989. K/QT-312. Oak Ridge Gaseous Diffusion Plant, Oak Ridge, Tenn.

McGaha, M. A. 1989d. Toxicity monitoring at ORGDP April-June 1989. K/QT-313. Oak Ridge Gaseous Diffusion Plant, Oak Ridge, Tenn.

McGaha, M. A. 1989e. Toxicity monitoring at ORGDP July-September 1988. K/QT-342. Oak Ridge Gaseous Diffusion Plant, Oak Ridge, Tenn. 
McKee, M. J., A. C. Hendricks, and R. E. Ebel. 1983. Effects of Naphthalene on Benzo[a]pyrene hydroxylase and cytochrome P-450 in Fundulus heteroclitus. Aquat. Toxicol. 3:103-114.

McMaster, M. E., G. J. Van Der Kraak, C. B. Portt, K. R. Munkittrick, P. K. Sibley, I. R. Smith, and D. G. Dixon. 1991. Changes in hepatic mixed-function oxygenase (MFO) activity, plasma steroid levels and age at maturity of a white sucker (Catostomus commersoni) population exposed to bleached Kraft pulp mill effluent. Aquat. Toxicol. 21: 199-218.

McMaster, W. M. 1967. Hydrologic data for the Oak Ridge area, Tennessee.

U.S. Geological Survey-Water Supply Paper No. 1838-N. U.S. Government Printing Office, Washington, D.C.

Minshall, G. W. 1978. Autotrophy in stream ecosystems. Bioscience 28:767-771.

Missouri Depart. of Conservation. 1989. Fishery Analysis Tools. Conservation Commission of the State of Missour. Jefferson City, Missouri. $396 \mathrm{pp}$.

Munkittrick, K. R., M. E. McMaster, C. B. Portt, G. J. Van Der Kraak, I. R. Smith, and D. G. Dixon. 1992. Changes in maturity, plasma sex steroid levels, hepatic mixed-function oxygenase activity, and the presence of external lesions in lake whitefish (Coregonus clupeaformis) exposed to bleached kraft mill effluent. Can. J. Fish. Aquat. Sci. 49: $1560-1569$.

NCCLS (National Committee for Clinical Laboratory Standards). 1979. NCCLS Approved Standards: ACS-1 Specification for Standard Protein Solution (Bovine Serum Albumin), 2nd ed. National Committee for Clinical Laboratory Standards, Villanova, $\mathrm{Pa}$.

NOAA (National Oceanic and Atmospheric Administration). 1990. Local climatological data: 1989 annual summary with comparative data, Oak Ridge, Tennessee. National Climatic Data Center, Asheville, N.C.

Neff, J. M. 1978. Polycyclic Aromatic Hydrocarbons. Applied Science Publisher, Ltd., London.

Payne J. F., and W. R. Penrose. 1975. Induction of aryl hydrocarbon benzo[a]pyrene hydroxylase in fish by petroleum. Bull. Environ. Contam. Toxicol. 14:112-116.

Phillips, G. R., P. A. Medvick, D. R. Skaar, and D. E. Knight. 1987. Factors affecting the mobilization, transport, and bioavailability of mercury in reservoirs of the upper Missouri 
River basin. Fish and Wildlife Report 10. United States Department of the Interior Fish and Wildlife Service, Washington, D.C.

Pielou, E. C. 1977. Mathematical ecology. John Wiley and Sons, New York.

Platts, W. S., W. F. Megahan, and G. W. Minshall. 1983. Methods for evaluating stream, riparian, and biotic conditions. U.S. Forest Service General Technical Report INT-138. Intermountain Forest and Range Experimental Station, Ogden, Utah.

Rada, R. G. and J. E. Findley. 1986. Environmental fate of mercury discharged into the upper Wisconsin River. Water, Air, and Soil Pollution. 29:57-76.

Railsback, S. F., B. D. Holcomb, and M. G. Ryon. 1989. A computer program for estimating fish population sizes and annual production rates. ORNL/TM-11061. Oak Ridge National Laboratory, Oak Ridge, Tenn.

Ricker, W. E. 1975. Chapter 9: Growth in length and weight. pp. 203-233. IN Computation and interpretation of biological statistics of fish populations. Bulletin 191. Department of the Environment, Fisheries and Marine Service, Ottawa, Canada.

Roche Diagnostic Systems. 1986. Reagent for total protein. Roche Diagnostic Systems Information Package, Item 44903 \& 44313. Nutley, N.J.

Ruby, S.M., D.R. Idler, and Y.P. So. 1993. Plasma vitellogenin, $17 \beta$-estradiol, $T_{3}$ and $T_{4}$ levels in sexually maturing rainbow trout Oncorhynchus mykiss following sublethal HCN exposure. Aquat. Toxicol. 26: 91-102.

Ryon, M. G. 1993. Fishes. IN Smith, J. G., S. M. Adams, L. A. Kszos, J. M. Loar, M. G. Ryon, and G. R. Southworth. 1993. First Report on the Oak Ridge K-25 Site Biological Monitoring and Abatement Program for Mitchell Branch. ORNL/TM-1 1073. Oak Ridge National Laboratory. Oak Ridge, Tenn. 128 pp.

Ryon, M. G. 1994a. Fishes. IN L. A. Kszos et al. 1994. Report on the Biological Monitoring Program at Paducah Gaseous Diffusion Plant, December 1992 to December 1993. ORNL/TM-12716. Oak Ridge National Laboratory. Oak Ridge, Tenn.

Ryon, M. G. 1994b. Fishes. IN Smith et al. 1994. Second Report on the Oak Ridge K-25 Site Biological Monitoring and Abatement Program for Mitchell Branch. ORNL/TM12150. Oak Ridge National Laboratory. Oak Ridge, Tenn.

Ryon, M. G. and J. M. Loar. 1988. A checklist of fishes on the Department of Energy Oak Ridge Reservation. J. Tenn. Acad. Sci. 53:97-102. 
SAS Institute, Inc. 1985a. SAS User's Guide: Basics, Version 5 Edition. SAS Institute, Inc., Cary, N.C.

SAS Institute, Inc. 1985b. SAS User's Guide: Statistics, Version 5 Edition. SAS Institute, Inc., Cary, N.C.

Scheib, W. J. 1987. ORGDP storm drain characterization. Final Report, K/HS-128 Part 2. Oak Ridge Gaseous Diffusion Plant, Oak Ridge, Tenn.

Seal, H. L. 1964. Multivariate Statistical Analysis for Biologists. John Wiley \& Sons, New York, N.Y.

Sheffy, T. B. and J. R. St. Amant. 1982. Mercury burdens in furbearers in Wisconsin. J. Wildl. Manage. 46:1117-20.

Shoemaker, J. L., L. A. Kszos, M. A. McGaha, P. E. Osborne, and R. Woods. 1990. Toxicity monitoring at ORGDP October-December 1989. K/QT-373. Oak Ridge Gaseous Diffusion Plant, Oak Ridge, Tenn.

Singh, S., and T. P. Singh. 1987. Evaluation of toxicity limit and sex hormone production in response to cythion and $\mathrm{BHC}$ in the vitellogenic catfish Clarias batrachus. Environ. Res. 42: $482-488$.

Sivarajah, K., C. S. Franklin and P. Williams. 1978. The effects of polychlorinated biphenyls on plasma steroid levels and hepatic microsomal enzymes in fish. J. Fish Biol. 13: $401-409$.

Small, J. W., Jr. 1975. Energy dynamics of benthic fishes in a small Kentucky stream. Ecology 56:827-840.

Smith et al., 1993. First Report on the Oak Ridge K-25 Site Biological Monitoring and Abatement Program for Mitchell Branch. ORNL/TM-11073. Oak Ridge National Laboratory, Oak Ridge, Tenn.

Smith et al., 1994. Second Report on the Oak Ridge K-25 Site Biological Monitoring and Abatement Program for Mitchell Branch. ORNL/TM-12150. Oak Ridge National Laboratory, Oak Ridge, Tenn.

Smith, J. G. 1992a. Benthic macroinvertebrates. IN J. M. Loar (ed.), First report on the Oak Ridge Y-12 Plant Biological Monitoring and Abatement Program for East Fork Poplar Creek. Y/TS-886. Oak Ridge National Laboratory, Oak Ridge, Tenn. 
Oak Creek watershed and the Clinch River. ORNL/TM-10804. Oak Ridge National Laboratory, Oak Ridge, Tenn.

Smith, J. G. 1994. Benthic macroinvertebrates. pp. 6-1 to 6-20. IN J. M. Loar (ed.), Third report on the Oak Ridge National Laboratory Biological Monitoring and Abatement Program for White Oak Creek watershed and the Clinch River. ORNL/TM-11358. Oak Ridge National Laboratory, Oak Ridge, Tenn.

Sokal, R. R., and F. J. Rohlf. 1981. Biometry, 2nd ed. W. H. Freeman and Company, San Francisco, Calif.

Southworth, G. R. 1990. PCB concentrations in stream sunfish in relation to chronic point sources. Water, Air, and Soil Pollution. 51:287-296.

Southworth G. R., M. J. Peterson, S. M. Adams, B. G. Blaylock. 1994. Estimation of appropriate background concentrations for assessing mercury contamination in fish. Bull. Environ. Contam. Toxicol. 53:211-218.

Steel, R. G. D., and J. H. Torrie. 1960. Principles and procedures of statistics with special reference to the biological sciences. McGraw-Hill, Inc., New York.

Stegeman, J. J., R. L. Binder, and A. Orren. 1979. Hepatic and extra-hepatic microsomal electron transport components and mixed function oxygenases in the marine fish Stenotomus versicolor. Biochem. Pharmacol. 28:3421-3439.

Stewart, A. J. 1994. Toxicity monitoring. IN J. M. Loar et al., Third report on the Oak Ridge National Laboratory Biological Monitoring and Abatement Program for White Oak Creek watershed and the Clinch River. ORNL/TM-11358. Oak Ridge National Laboratory, Oak Ridge, Tenn.

Suchanek, T. H., P. J. Richerson, L. A. Woodward, D. G. Slotton, L. J. Holts, and C. E. E. Woodmansee. 1993. Survey and evaluation of mercury in sediment, water, plankton, periphyton, benthic invertebrates and fishes within the aquatic ecosystem of Clear Lake, California. A report prepared for the Environmental Protection Agency Region 9: Superfund Program. Institute of Ecology, Division of Environmental Studies, University of California/Davis.

Takizawa, K., H. Yagi, D.M. Jerina and D.R. Mattison. 1984. Murine starin differences in ovotoxicity following intraovarian injection with benzo(a)pyrene, (+)-(7R, 8S)-oxide, $(-)-$ (7R,8R)-dihydodiol, or (+)-(7R,8S)-diol-(9S,10R)-epoxide-2. Canc. Res. 44: 2571-2576. 
Takizawa, K., H. Yagi, D.M. Jerina and D.R. Mattison. 1984. Murine starin differences in ovotoxicity following intraovarian injection with benzo(a)pyrene, $(+)-(7 \mathrm{R}, 8 \mathrm{~S})$-oxide, $(-)-$ (7R,8R)-dihydodiol, or (+)-(7R,8S)-diol-(9S,10R)-epoxide-2. Canc. Res. 44: 2571-2576.

TVA (Tennessee Valley Authority). 1985. Instream contaminant study, Task 4: Fish sampling and analysis. Report to U.S. Department of Energy, Oak Ridge Operations Office. Tennessee Valley Authority, Office of Natural Resources and Economic Development, Knoxville, Tenn.

TVA (Tennessee Valley Authority). 1986. Instream contaminant study, Task 5: Summary report. Report to U.S. Department of Energy, Oak Ridge Operations Office. Tennessee Valley Authority, Office of Natural Resources and Economic Development, Knoxville, Tenn.

Thomas, P. 1990. Teleost model for studying the effects of chemicals on female reproductive endocrine function. J. Exp. Zool. Suppl. 4: 126-128.

Tietz, N. W. 1986. Textbook of Clinical Chemistry. W. B. Saunders, Co., Philadelphia, Pa. Tiffany, T. O., J. M. Jansen, C. A. Burtis, J. B. Overton, and C. D. Scott. 1972. Enzymatic kinetic rate and end-point analyses of substrate by use of a GEMSAEC fast analyzer. Clin. Chem. 18:829-840.

Travis, C. C., F. O. Hoffman, B. G. Blaylock, K. L. Daniel, C. S. Gist, C. W. Weber. 1986. Preliminary review of TVA fish sampling and analysis report. Report of Task Group Five to Oak Ridge Task Force. January 1986. Mimeo.

Truscott, B., J. M. Walsh, M. P. Barton, J. F. Payne, and D. R. Idler. 1983. Effect of acute exposure to crude petroleum on some reproductive hormones in salmon and flounder. Comp. Biochem. Physiol. 75C: 121-130.

Valentine, R. L., C. A. Bache, W. H. Gutenmann, and D. J. Lisk. 1988. Tissue concentrations of heavy metals and polychlorinated biphenyls in raccoons in central New York. Bul. Environm. Contam. Toxicol. 40:711-16.

Weber, C. I. (ed.). 1973. Biological field and laboratory methods for measuring the quality of surface waters and effluents. EPA 670/4-73-001. National Environmental Research Center, U.S. Environmental Protection Agency, Cincinnati, Oh.

Weber, C. I., W. H. Peltier, T. J. Norbert-King, W. B. Horning II, F. A. Kessler, J. R. Menkedick, T. W. Neiheisel, P. A. Lewis, D. J. Klemm, Q. H. Pickering, E. L. Robinson, J. M. Lazorchak, L. J. Wymer, and R. W. Freyberg. 1989. Short-term methods for 
estimating the chronic toxicity of effluents and receiving waters to freshwater organisms. 2nd Edition. EPA/600/4-89/001. U.S. Environmental Protection Agency, Cincinnati, Oh. Whitley, L. S. 1982. Aquatic Oligochaeta. IN A. R. Brigham, W. U. Brigham, and A. Gnilka (eds.), Aquatic Insects and Oligochaetes of North and South Carolina. Midwest Aquatic Enterprises, Mahomet, Ill.

Wiederholm, T. 1984. Responses of aquatic insects to environmental pollution. pp. 508-557. IN V. H. Resh and D. M. Rosenberg (eds.), The Ecology of Aquatic Insects. Praeger Publishers, New York.

Williams, D. D. and H. B. N. Hynes. 1976. The recolonization mechanism of stream benthos. Oikos 27:265-72.

Williams, D. D. and H. B. N. Hynes. 1977. Benthic community development in a new stream. Canadian J. Zool. 55:1071-76.

Wren, C. D. 1984. Distribution of metals in tissues of beaver, raccoon, and otter from Ontario, Canada. The Science of the Total Environment 34:177-84.

Zar, 1984. Biostatistical analysis. Prentice-Hall, Inc., Englewood Cliffs, N.J. 
APPENDIX A

WATER QUALITY DATA FOR MITCHELL BRANCH 


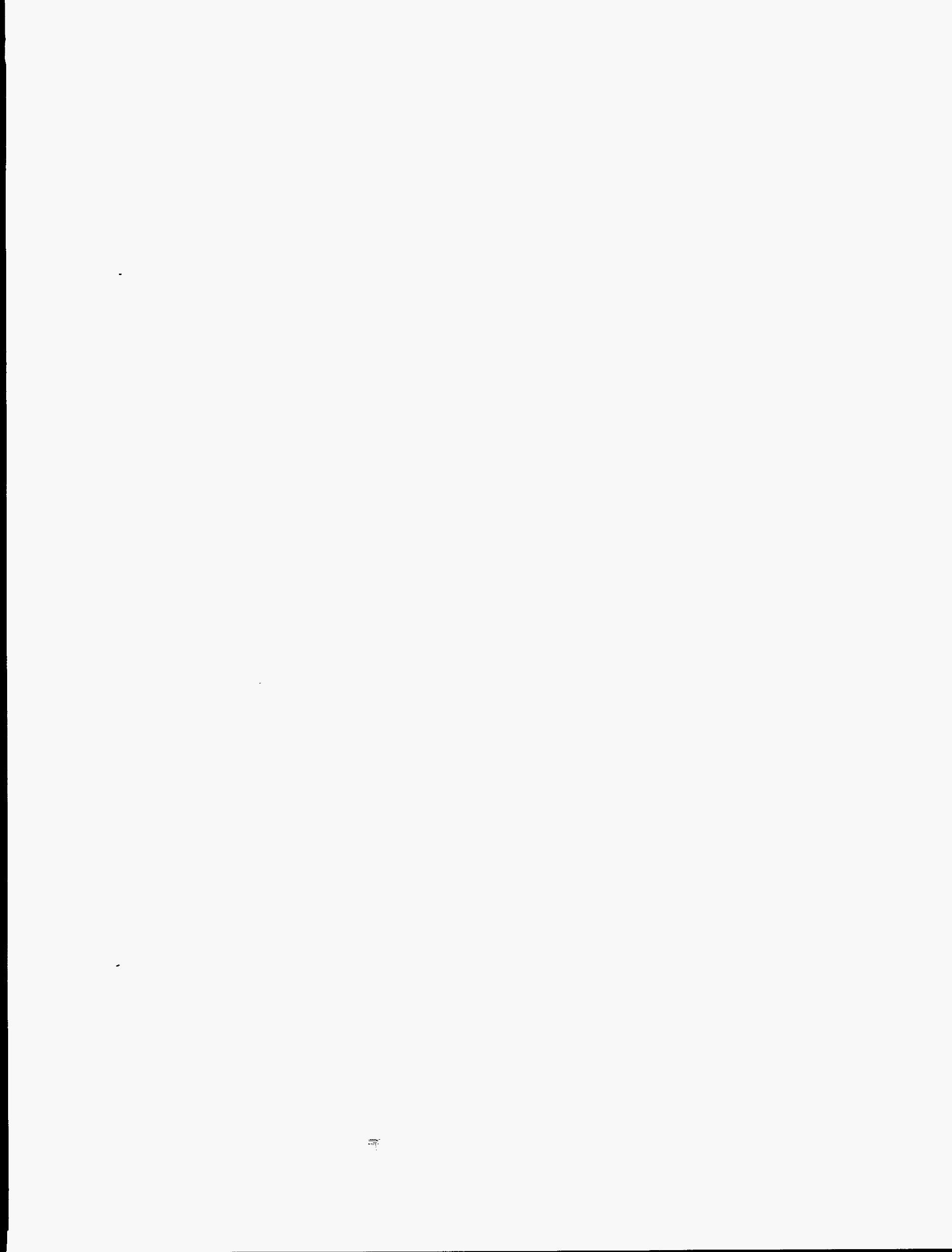


Table A.1. Mean concentrations of National Pollutant Discharge Elimination System parameters detected in the water at K-1700 (Mitchell Branch kilometer 0.12)

Measured in $\mathrm{mg} / \mathrm{L}$ unless otherwise noted

\begin{tabular}{|c|c|c|c|c|c|}
\hline \multirow{2}{*}{ Parameter } & \multicolumn{4}{|c|}{ Mean (range) } & \multirow{2}{*}{$\begin{array}{l}\text { Reference } \\
\text { value }\end{array}$} \\
\hline & 1990 & 1991 & 1992 & 1993 & \\
\hline 1,1,1-Trichloroethane $(\mu \mathrm{g} / \mathrm{L})$ & $2.23(<0.4-5)$ & & & & \\
\hline 1,1,-Dichloroethane $(\mu \mathrm{g} / \mathrm{L})$ & $4.38(<0.6-5)$ & & & & \\
\hline 1,2,-Dichloroethane $(\mu \mathrm{g} / \mathrm{L})$ & $5.74(<5-36)$ & & & & \\
\hline 1,2 Dichloroethene & & & & $0.011(0.006-0.022)$ & $0.07^{a}$ \\
\hline Aluminum & $0.288(<0.032-2.9)$ & $0.287(0.031-3.5)$ & $<0.2697(<0.1-3.5)$ & & 1.0 \\
\hline Alkalinity & & & & $91.75(64-155)$ & ; \\
\hline Beryllium & & $0.0011(0.0003-0.003)$ & & & \\
\hline Bromodichloromethane & $4.51(<0.8-5)$ & & & & \\
\hline Cadmium & $0.002(<0.002-0.004)$ & $0.0026(0.002-0.049)$ & & & \\
\hline Calcium Hardness & & & & $81.5(59-130)$ & \\
\hline Chemical Oxygen Demand & $5.87(<5-28)$ & $6.46(<5-36)$ & $<7.035(<5-152)$ & $8.5(5-14)$ & \\
\hline Chloride & & & & $17(4-39.1)$ & $250^{b}$ \\
\hline Chlorine & & & & $0.045(0.01-0.1)$ & \\
\hline Chloroform ( $\mu \mathrm{g} / \mathrm{L})$ & $4.19(<0.5-13)$ & & & & \\
\hline Chromium & $0.01(<0.01-0.029)$ & $0.011(0.01-0.055)$ & $<0.0104(<0.01-0.012)$ & & 0.08 \\
\hline Color & & & & $495(490-500)$ & \\
\hline Conductivity & & & & $271.5(180-404)$ & \\
\hline Dissolved Oxygen & & & & $8.82(7.6-11.5)$ & $5.0^{c}$ \\
\hline Dissolved Solids & $306.26(88-892)$ & $218.9(74-1080)$ & $211.8(98-2700)$ & $196(130-262)$ & $500^{b}$ \\
\hline Flow $(\mathrm{L} / \mathrm{s})$ & 35.49 & $31.48(2.77-325.26)$ & $28.85(11.39-176.98)$ & $?$ & \\
\hline Fluoride & $0.186(<0.1-0.9)$ & $0.1863(0.1-0.9)$ & $<0.17(<0.1-0.3)$ & $0.2(0.2-0.2)$ & $4.0^{a}$ \\
\hline Iron & & & & $0.6775(0.39-0.82)$ & $0.3^{b}$ \\
\hline
\end{tabular}


Table A.1 (continued)

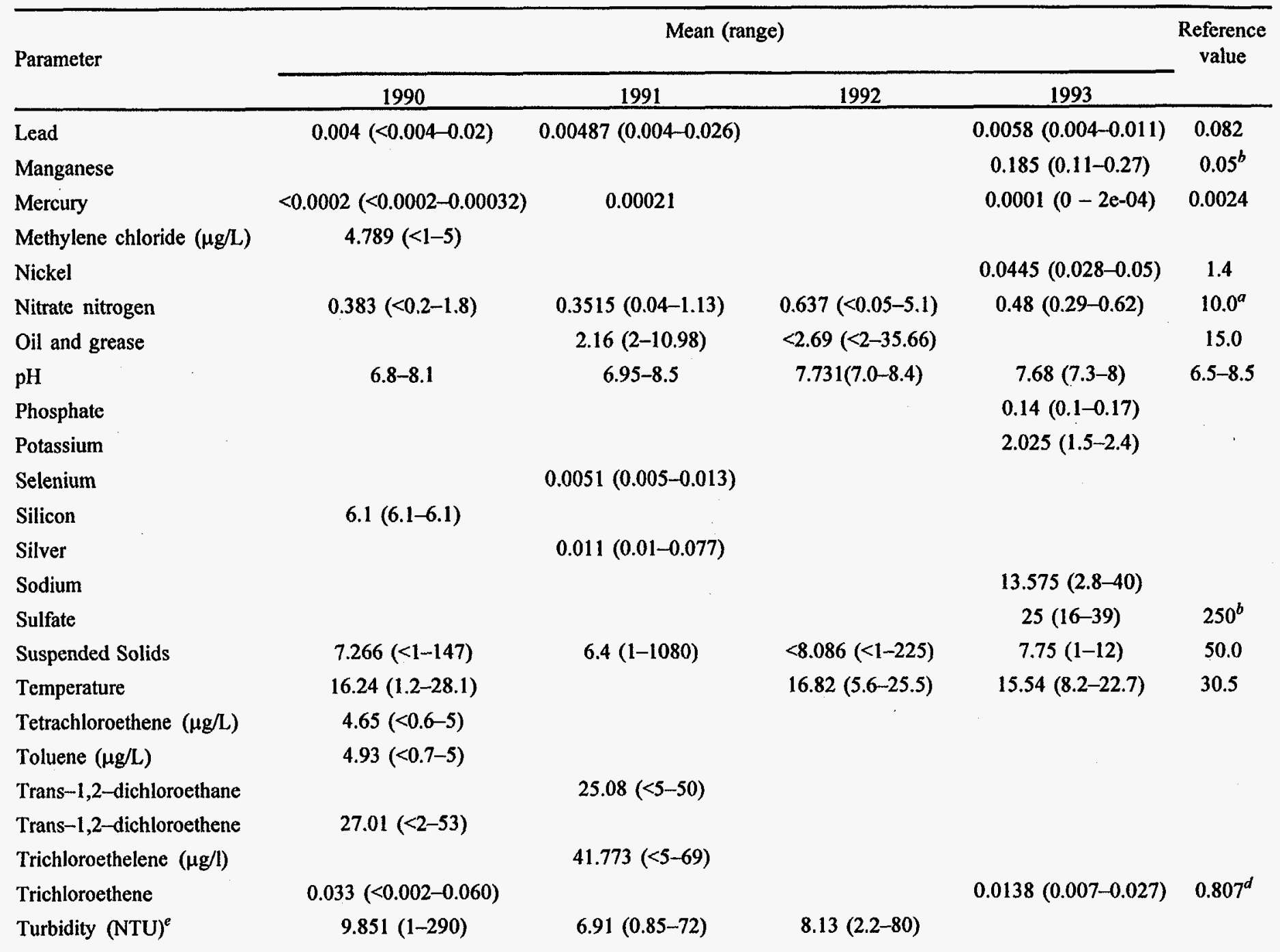


Table A.1 (continued)

\begin{tabular}{|c|c|c|c|c|c|}
\hline \multirow{2}{*}{ Parameter } & \multicolumn{4}{|c|}{ Mean (range) } & \multirow{2}{*}{$\begin{array}{c}\text { Reference } \\
\text { value }\end{array}$} \\
\hline & 1990 & 1991 & 1992 & 1993 & \\
\hline Zinc & $0.023(<0.0057-0.29)$ & & $<0.0252(<0.02-0.092)$ & $0.0347(0.02-0.056)$ & 0.117 \\
\hline
\end{tabular}

Note: All reference values are Tennessee Water Quality Standards for Fish and Aquatic Life, unless otherwise noted. Table compiled from Komegay et al., 1991, 1992, 1993, 1994 (see Chapter 8 for full citations).

${ }^{a}$ Tennessee Primary Drinking Water Maximum Contaminant Level.

${ }^{b}$ Tennessee Secondary Drinking Water Maximum Contaminant Level.

'Minimum value.

${ }^{d}$ Tennessee Water Quality Standard for Recreation.

${ }^{e}$ Nephelometric turbidity units. 
Table A.2. Mean concentrations of National Pollutant Discharge Elimination System parameters detected in the water at K-1007-B Pond

Measured in $\mathrm{mg} / \mathrm{L}$ unless otherwise noted

\begin{tabular}{|c|c|c|c|c|c|}
\hline \multirow[t]{2}{*}{ Parameter } & \multicolumn{4}{|c|}{ Mean (range) } & \multirow[t]{2}{*}{ Reference value } \\
\hline & 1990 & 1991 & 1992 & 1993 & \\
\hline Alkalinity & & & & $96.25(75-108)$ & \\
\hline Calcium Hardness & & & & $73.50(48.00-91.00)$ & \\
\hline Chemical Oxygen & $8.649(<4.5-23)$ & $8.939(<5-21)$ & $<7.5244(<5-22)$ & $16.50(5.00-40.00)$ & \\
\hline Chloride & & & & $10.05(9.40-11.00)$ & $250^{a}$ \\
\hline Chlorine & & & & $0.08(0.04-0.12)$ & \\
\hline Chromium & $0.01(<0.01-0.037)$ & $0.0106(0.01-0.04)$ & $<0.01(<0.01-0.0105)$ & & \\
\hline Color & & & & $498(490-500)$ & \\
\hline Conductivity & & & & $338.00(216.00-588.00)$ & ' \\
\hline Dissolved Oxygen & $9.52(4.3-20)$ & & $9.5608(5.1-18)$ & $9.85(7.50-11.50)$ & $5.0^{b}$ \\
\hline Dissolved Solids & & & & $157.50(138.00-186.00)$ & $500^{a}$ \\
\hline Flow (L/s) & & $86.3(15.02-2037.9)$ & $45.5(3.9-635.2)$ & & \\
\hline Fluoride & $0.132(<0.1-0.2)$ & $0.1217(<0.01-1)$ & $<0.1244(<0.1-0.2)$ & $0.10(0.10-0.10)$ & $4.0^{c}$ \\
\hline Iron & & & & $0.33(0.12-0.61)$ & $0.3^{a}$ \\
\hline Manganese & & & & $0.06(0.04-0.11)$ & 0.05 \\
\hline Nickel & & & & $0.04(0.05-0.01)$ & 1.40 \\
\hline Nitrate & & & & $0.23(0.10-0.45)$ & $10.0^{c}$ \\
\hline Oil and Grease & & $2.03(<2-3.5)$ & $<2.259(<0.1-7.53)$ & & 15.0 \\
\hline $\mathrm{pH}$ (standard units) & $7.1-9.3$ & $7-9.5$ & $8.388(7.3-9.2)$ & $8.58(7.80-9.00)$ & $6.5-8.5$ \\
\hline Potassium & & & & $2.18(1.90-2.90)$ & \\
\hline Sodium & & & & $4.55(4.00-4.90)$ & \\
\hline Sulfate & & & & $22.75(20.00-28.00)$ & $250^{a}$ \\
\hline Suspended Solids & $9.328(<1-20)$ & $10.144(1-24)$ & $8.9512(4-25)$ & $12.75(5.00-24.00)$ & \\
\hline Temperature $\left({ }^{\circ} \mathrm{C}\right)$ & $18.198(4.8-29.8)$ & & & $19.43(6.30-30.30)$ & 30.50 \\
\hline Total Phosphate as & & & & $0.12(0.06-0.17)$ & \\
\hline Uranium & & & $0.001(0.001-0.001)$ & & \\
\hline Zinc & & & & $0.02(0.02-0.03)$ & 0.12 \\
\hline
\end{tabular}

Note: All reference values are Tennessee Water Quality Standards for Fish and Acquatic Life, unless otherwise noted. Table compiled from data in Kornegay et al., 1991, 1992, 1993 and 1994 (see Chapter 8 for full citations).

${ }^{a}$ Tennessee Secondary Drinking Water Maximum Contaminant Level

${ }^{b}$ Minimum value.

Tennessee Primary Drinking Water Maximum Contaminant Level. 
Table A.3. Mean concentrations of National Pollutant Discharge Elimination System parameters detected in the water at the Central Neutralization Facility (K-1407-J basin)

Expressed as $\mathrm{mg} / \mathrm{L}$ unless otherwise noted

\begin{tabular}{|c|c|c|c|c|c|}
\hline \multirow[t]{2}{*}{ Parameter } & \multicolumn{4}{|c|}{ Mean (range) } & \multirow[t]{2}{*}{ Reference value ${ }^{a}$} \\
\hline & 1990 & 1991 & 1992 & 1993 & \\
\hline Total toxic organics & $<0.145(<0.005-2.123)$ & & & & \\
\hline 1,1,1-Trichloroethane & $0.00531(<0.0005-0.033)$ & & & $<0.0005(<0.0005-<0.0005)$ & \\
\hline 1,1-Dichloroethane & $0.004912(<0.0007-0.006)$ & & & & \\
\hline 1,1-Dichloroethene & $0.005(<0.0009-0.021)$ & & $<0.0046(<0.0012-0.006)$ & & \\
\hline 1,2-Dichloropropane & & & $<0.005(<0.0007-6)$ & & \\
\hline 2,4-Dichlorophenol & $0.00984(<0.001-0.01)$ & & & & \\
\hline 4-Nitrophenol $(\mu \mathrm{g} / \mathrm{L})$ & $52.17(50-200)$ & & & & \\
\hline Acetone & & & & $<0.01(<0.01-<0.01)$ & \\
\hline Acetonitrile & & & & $<0.01(<0.01-<0.01)$ & \\
\hline Aluminum & $0.205(<0,02-2.8)$ & $0.205(0.095-1.9)$ & & & \\
\hline Ammonia nitrogen & $0.281(<0.14-1.7)$ & $0.201(<0.2-0.25)$ & & & \\
\hline Anthracene $(\mu \mathrm{g} / \mathrm{L})$ & $9.931(<6-10)$ & & & & \\
\hline Aroclor-1254 & & & $<0.0009(<0.005-0.00019)$ & & \\
\hline Arsenic & $0.005(<0.005-0.011)$ & & $<0.0038(<0.002-0.004)$ & & \\
\hline Barium & $0.099(<0.0066-0.1)$ & $0.098(0.022-0.33)$ & & & \\
\hline Benzene & $0.00489(<0.0008-0.005)$ & & & $<0.0007(<0.0007-<0.0007)$ & \\
\hline Benzidine $(\mu \mathrm{g} / \mathrm{L})$ & & $10.43(<10-40)$ & & & \\
\hline Benzo(a)anthracene $(\mu \mathrm{g} / \mathrm{L})$ & & $3.6(10.43-<40)$ & & & \\
\hline Bis(2-ethylhexyl)phthalate & $9.982(<-1.2)$ & & & & \\
\hline Boron & $0.084(<0.004-1.2)$ & $0.367(0.019-1.6)$ & & & \\
\hline Bromide & & $2.39(1-10)$ & & & \\
\hline Bromoform & & & & $<0.0019(<0.0019-<0.0019)$ & \\
\hline Bromodichloromethane & $0.0047(<0.0005-0.006)$ & $0.004996(<0.002-0.007)$ & $<0.0044(<0.0017-0.007)$ & & \\
\hline Butylbenzylphthalate & & & $<0.0087(<0.0021-0.005)$ & & \\
\hline Cadmium & & $<0.0021(<0.002-0.0057)$ & & $<0.002(0.003<<0.002)$ & 0.69 \\
\hline Carbontetrachloride & & & & $<0.0006(<0.0006-<0.0006)$ & 0.5 \\
\hline Chemical Oxygen Demand & $16.28(<5-89)$ & $<15.5(<5-343)$ & $<5.4687(<5-11)$ & $<8(31-<1)$ & $250^{b}$ \\
\hline
\end{tabular}


Table A.3 (continued)

\begin{tabular}{|c|c|c|c|c|c|}
\hline \multirow[t]{2}{*}{ Parameter } & \multicolumn{4}{|c|}{ Mean (range) } & \multirow[t]{2}{*}{ Reference value } \\
\hline & 1990 & 1991 & 1992 & 1993 & \\
\hline Chloride & $153.08(20-883)$ & $626.21(20-3090)$ & $309.96(35-1927)$ & $524(2051-75)$ & 39479 \\
\hline Chlorine, total residual & $0.044(<0.02-0.5)$ & $<0.072(<0.02-0.22)$ & $0.0316(0.01-0.09)$ & $<0.05(0.13-<0.05)$ & 0.14 \\
\hline Chlorobenzene & & & $<0.0049(<0.0004-0.001)$ & & \\
\hline Chloroethane & & & $<0.0088(<0.0017-0.01)$ & & \\
\hline Chlorodibromomethane & & & & $<0.0008(<0.0008-<0.0008)$ & \\
\hline Chloroform & $0.00438(<0.0003-0.031)$ & $<0.00586(<0.001-0.052)$ & $<0.0063(<0.0045-0.043)$ & $0.0031(0.0055-0.0018)$ & 0.5 \\
\hline Chromium & $0.01(<0.01-0.05)$ & $0.014(<10-0.1)$ & $<0.0137(<0.01-0.017)$ & $<0.01(0.02-<0.01)$ & 2.77 \\
\hline Copper & $0.011(<004-0.1)$ & $<0.014(<0.004-0.081)$ & $<0.0103(<0.004-0.04)$ & $<0.007(0.011-<0.004)$ & 2.15 \\
\hline Cyanide colorimetric & $0.081(<0.002-0.1)$ & $<0.11(<0.1-0.33)$ & $<0.124(<0.1-0.14)$ & & \\
\hline Di-n-butylphthalate & & & $<0.0074(<0.0024-0.004)$ & & \\
\hline Dichlorobromomethane & & & & $<0.0017(<0.0017-<0.0017)$ & \\
\hline Dissolved solids $(\mu \mathrm{g} / \mathrm{L})$ & $658.3(182-2.394)$ & $2077.2(260.7322)$ & $1671.475(498-3864)$ & & $500^{b}$ \\
\hline Ethylbenzene & $0.00495(<0.0008-0.005)$ & & & $<0.0005(<0.0005-<0.0005)$ & \\
\hline Fluoranthene $(\mu \mathrm{g} / \mathrm{L})$ & $9.948(<8-10)$ & . & & & \\
\hline Fluoride & $1.452(0.2-11)$ & $13.2(0.2-71)$ & & & $4.0^{\circ}$ \\
\hline Flow, $L / s$ & & & $5.12(0-27.16)$ & $4.82(0-19.27)$ & \\
\hline Iron & $0.552(<0.05-9.9)$ & $0.68(0.099-3.3)$ & $0.2789(0.06-0.8)$ & & $0.3^{b}$ \\
\hline Kjeldahl nitrogen & $1.244(<0.6-3)$ & $1.08(0.84-2.74)$ & & & \\
\hline Lead & $0.005(<0.004-0.03)$ & $<0.0046(<0.004-0.016)$ & $<0.004 \quad(<0.002-0.0072)$ & $<0.004(<0.004-<0.004)$ & 0.69 \\
\hline Magnesium & $12.84(8-17)$ & $17.36(8.9-47)$ & & & \\
\hline Manganese & $0.049(<0.0089-0.28)$ & $0.34(<0.01-0.342)$ & $<0.0328(<0.01-0.079)$ & & $0.3^{b}$ \\
\hline MBAS & & $<0.203(<0.2-0.3)$ & & & \\
\hline Mercury & $<0.001(<0.0002-0.0045)$ & & & & \\
\hline Methylethylketone & & & & $<0.01(<0,01-<0.01)$ & \\
\hline Methylene chloride & $0.00616(<0.0004-0.09)$ & $0.00566(<0.002-0.019)$ & $<0.0042(0.0012-0.011)$ & $<0.0012(<0.0012-<0.0012)$ & \\
\hline Naphthalene & & & & $<0.0011(<0.0016-<0.0009)$ & \\
\hline Nickel & $0.071(<0.024-0.5)$ & & $<0.0618(<0.01-0.15)$ & $<0.07(0.1-<0.05)$ & 3.98 \\
\hline Nitrate nitrogen & & $<2.02(<0.2-23)$ & & & $10.0^{c}$ \\
\hline
\end{tabular}


Table A.3 (continued)

\begin{tabular}{|c|c|c|c|c|c|}
\hline \multirow[t]{2}{*}{ Parameter } & \multicolumn{4}{|c|}{ Mean (range) } & \multirow[t]{2}{*}{ Reference value ${ }^{a}$} \\
\hline & 1990 & 1991 & 1992 & 1993 & \\
\hline Oil and grease & $2.021(<2-3.79)$ & $<2.3(<2.14 .5)$ & $<2.533(<2-12.4)$ & $<.1(3.8-<2)$ & 30 \\
\hline РCB & & & & $<0.0005(<0.0005-<0.0005)$ & 0.0001 \\
\hline PCB (Aroclor-1250) $(\mu \mathrm{g} / \mathrm{L})$ & & $1.01(<1-1.4)$ & & & \\
\hline PCB (Aroclor-1254) $(\mu \mathrm{g} / \mathrm{L})$ & $0.984(<0.27-1)$ & & & & \\
\hline pH (standard units) & $7.89(7.0-9.3)$ & $6.7-8.9$ & $7.9451(7.3-8.9)$ & $(6.0-8.7)$ & $6.0-9.0$ \\
\hline Phenanthrene $(\mu \mathrm{g} / \mathrm{L})$ & $9.913(<5-10)$ & & & & \\
\hline Phenol $(\mu \mathrm{g} / \mathrm{L})$ & $10.379(<6-20)$ & & & & \\
\hline Phenols $(\mu \mathrm{g} / \mathrm{L})$ & $0.07(<0.01-2)$ & $<0.07(0.03-1.5)$ & & & \\
\hline Phosphorus & $1.536(<0.2-15)$ & $<3.06(<0.2-3.7)$ & & & \\
\hline Pyrene $(\mu \mathrm{g} / \mathrm{L})$ & $10.069(<9.15)$ & & & & \\
\hline Selenium & $0.005(<0.004-0.0057)$ & & & & \\
\hline Silver & $0.01(<0.006-<0.01)$ & $<0.011(<0.01-0.06)$ & & $0.01(0.02-<0.01)$ & 0.43 \\
\hline Sulfate & $234.239(49-576)$ & $553.23(135-1500)$ & $426.88(140-1000)$ & & $250^{b}$ \\
\hline Sulfide & & $<1.02(<1-2)$ & & & \\
\hline Sulfite & & $<1.38(<0.1-2)$ & & & \\
\hline Total suspended solids & $7.097(<1-576)$ & $7.18(0.1-36)$ & $4.7(<1-46)$ & $4(36-1)$ & 40 \\
\hline Temperature $\left({ }^{\circ} \mathrm{C}\right)$ & $20.285(0-34.1)$ & & $19.59(8.5-32.4)$ & $23.3(35.3-9.4)$ & $d$ \\
\hline Tetrachloroethene $(\mu \mathrm{g} / \mathrm{L})$ & $5.101(<0.6-59)$ & & & & \\
\hline Tetrachloroethylene & & & & $<0.0004(<0.0004-<0.0004)$ & 0.7 \\
\hline Tin & $0.01(<0.01-0.013)$ & $<0.02(<0.01-0.05)$ & & & \\
\hline Titanium & $0.004(<0.003-0.068)$ & $<0.0053(<0.003-0.03)$ & & & \\
\hline Toluene & $0.0048(<0.0008-0.006)$ & $<0.00503(<0.005-0.011)$ & & $<0.0006(<0.0006-<0.0006)$ & \\
\hline Total organic carbon & $5.12(2-15)$ & $<4.05(<1-19)$ & & & \\
\hline Total phosphate & $4.03(0.5-21)$ & $9.32(0.6-92)$ & & & \\
\hline Total toxic organics & & & & $0.0038(0.0064-0.0022)$ & 2.13 \\
\hline Trans-1,2-dichloroethene $(\mu \mathrm{g} / \mathrm{L})$ & $8.169(<1.64)$ & $<5.04(<5.8)$ & & & \\
\hline Trans-1,2-dichloropropene & $5.024(<0.08-460)$ & & & & \\
\hline Trichloroethene & $0.0174(<0.0008-0.00223)$ & & $<0.0042(<0.00145-0.007)$ & & \\
\hline
\end{tabular}


Table A.3 (continued)

\begin{tabular}{|c|c|c|c|c|c|}
\hline \multirow[t]{2}{*}{ Parameter } & \multicolumn{4}{|c|}{ Mean (range) } & \multirow[t]{2}{*}{ Reference value ${ }^{a}$} \\
\hline & 1990 & 1991 & 1992 & 1993 & \\
\hline Trichloroethylene & . & & & $<0.0035(0.0041-<0.0009)$ & 0.5 \\
\hline Vinyl chloride & $0.09768(<0.001-0.01)$ & & $<0.0096(<0.0015-0.002)$ & $<0.0015(<0.0015-<0.0014)$ & 0.2 \\
\hline Zinc & $0.033(<0.02-0.31)$ & $<0.028(<0.002-0.28)$ & $<0.0276(<0.02-0.37)$ & $<0.03(0.056<0.02)$ & 2.61 \\
\hline
\end{tabular}

Note: Table compiled from data in Kornegay et al. 1991, 1992, 1993, 1994 (see Chapter 8 for full citations).

${ }^{a}$ NPDES permit limit unless otherwise noted.

${ }^{b}$ Tennessee Secondary Drinking Water Maximum Contaminant Level.

Tennessee Primary Drinking Water maximum Contaminant Level.

${ }^{d}$ Effluent must not cause the temperature of receiving stream to exceed $30.5^{\circ} \mathrm{C}$. 
Table A.4. Mean concentrations of National Pollutant Discharge Elimination System parameters detected in the water at $\mathrm{K}-1700-\mathrm{E} / \mathrm{F}$ ponds

Expressed as $\mathrm{mg} / \mathrm{L}$ unless otherwise noted

\begin{tabular}{|c|c|c|}
\hline \multirow[t]{2}{*}{ Parameter } & \multicolumn{2}{|c|}{ Mean (range) } \\
\hline & 1990 & 1991 \\
\hline Arsenic & $0.005(<0.005-0.0065)$ & \\
\hline Cadmium & $0.002(<0.002-0.004)$ & \\
\hline Chromium & $0.01(<0.01-0.011)$ & \\
\hline Copper & $0.024(<0.004-0.21)$ & $0.0242(0.00733-0.037)$ \\
\hline Flow & & $0.13947(0-0.6554)$ \\
\hline Iron & $0.364(<0.05-1.9)$ & $0.745(0.2-2.4)$ \\
\hline Lead & $0.004(<0.004-0.0067)$ & $0.0044(0.004-0.008)$ \\
\hline Manganese & $0.134(0.023-1.1)$ & $0.181(0.06-0.54)$ \\
\hline Nickel & $0.198(<0.041-2.6)$ & $0.086(<0.05-0.239)$ \\
\hline Oil and grease & $2.024(<2-3.52)$ & \\
\hline PCB (Aroclor 1254) $(\mu \mathrm{g} / \mathrm{L})$ & & $1.107(<1.0-2.6)$ \\
\hline pH (standard units) & $3.7-9.6$ & $6.4-9.0$ \\
\hline Selenium & & $0.006(0.005-0.02)$ \\
\hline Silver & $0.009(<0.006-0.01)$ & \\
\hline Sulfate & $649.47(75-1440)$ & $1007.25(76-1660)$ \\
\hline Suspended solids & $8.95(1-42)$ & $8.286(76-1660)$ \\
\hline Temperature $\left({ }^{\circ} \mathrm{C}\right)$ & $19.3(3.5-38.3)$ & \\
\hline Thorium (pCi/L) & $5.88(1.05-10.7)$ & \\
\hline Zinc & $0.22(<0.006-0.12)$ & $0.025(0.02-0.047)$ \\
\hline
\end{tabular}

Note: Table compiled from data in Kornegay et al. 1991, and 1992 (See Chapter 8 for full citation). 
Table A.5. National Pollutant Discharge Elimination System Compliance at K-1700 at Mitchell Branch kilometer 0.12, K-1700-B pond, K-1407-E/F ponds, and K-1407-J basin, 1990-1993

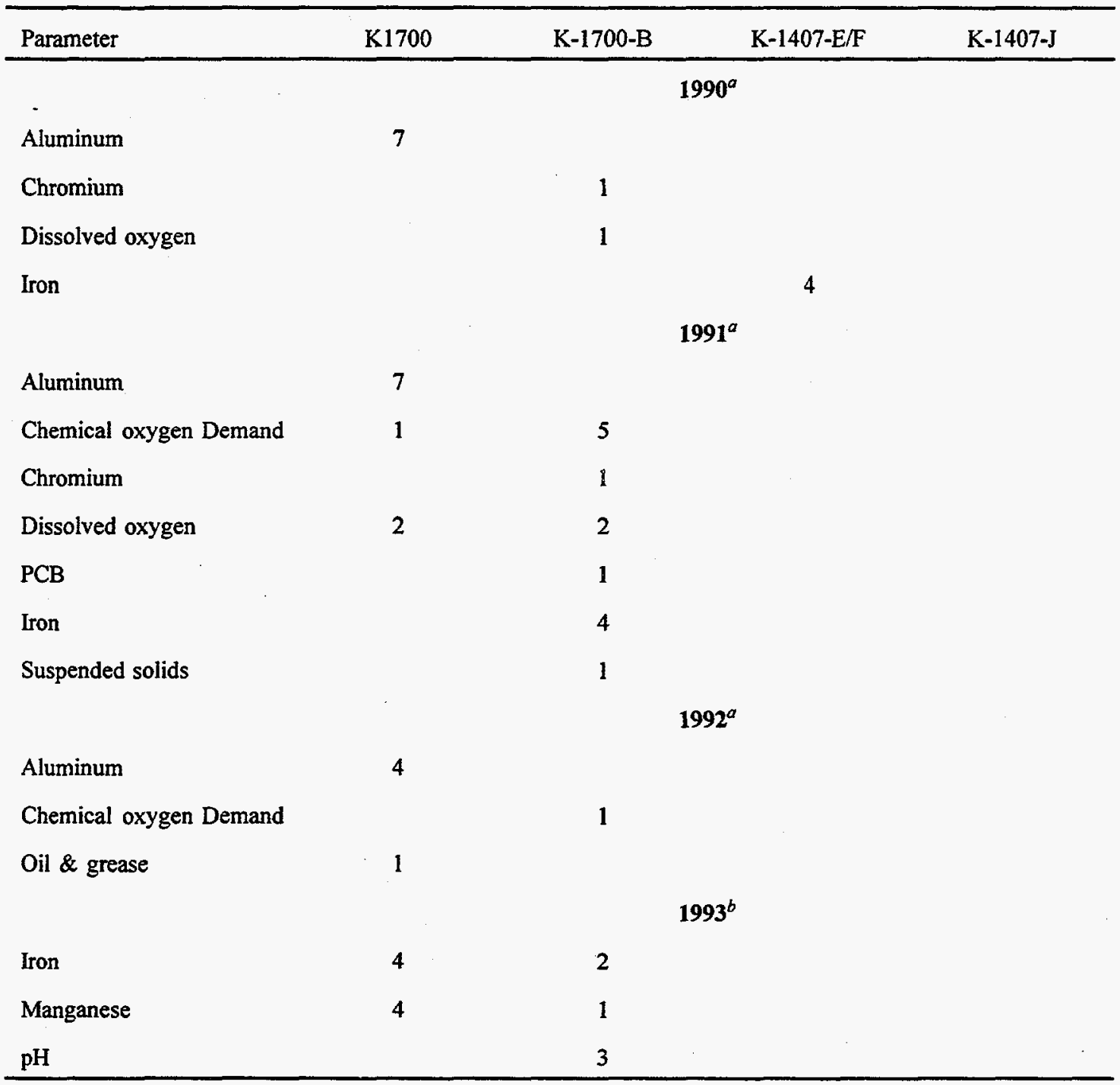

Note: Compliance was $100 \%$ at $\mathrm{K}-1407-\mathrm{J}$.

Number of noncompliances for this year.

Number of values exceeding reference (see Tables A.1-A.4) for this year. 
Table A.6. Monthly means ( $\pm 1 \mathrm{SD}$ ) and range (number of days of record) of water temperature $\left({ }^{\circ} \mathrm{C}\right)$ at Mitchell Branch kilometer (MIK) 0.50 just below the outfall of storm drain 190 and at two reference sites, Grassy Creek

kilometer (GCK) 2.4 and Scarboro Creek kilometer (SCK) 2.2

\begin{tabular}{|c|c|c|c|c|c|}
\hline \multicolumn{2}{|c|}{ Sampling period } & \multicolumn{2}{|c|}{ MIK 0.50} & \multicolumn{2}{|c|}{ GCK 2.4} \\
\hline Year & Month & Mean & Range & Mean & Range \\
\hline \multirow[t]{9}{*}{1987} & April & $\begin{array}{l}17.7 \\
(2.1)\end{array}$ & $\begin{array}{c}12.1-24.7 \\
\text { (20) }\end{array}$ & $\begin{array}{l}13.2 \\
(2.4)\end{array}$ & $\begin{array}{c}6.8-19.5 \\
(20)\end{array}$ \\
\hline & May & $\begin{array}{l}22.2 \\
(2.2)\end{array}$ & $\begin{array}{c}17.1-29.6 \\
(31)\end{array}$ & $\begin{array}{l}16.0 \\
(2.0)\end{array}$ & $\begin{array}{c}9.9-19.7 \\
(31)\end{array}$ \\
\hline & June & $\begin{array}{l}23.5 \\
(3.9)\end{array}$ & $\begin{array}{c}11.9-41.2 \\
(30)\end{array}$ & $\begin{array}{l}17.8 \\
(1.4)\end{array}$ & $\begin{array}{c}13.3-21.7 \\
(30)\end{array}$ \\
\hline & July & $\begin{array}{l}25.3 \\
(6.4)\end{array}$ & $\begin{array}{c}16.8-41.4 \\
(5.5)\end{array}$ & $\begin{array}{l}18.9 \\
(1.2)\end{array}$ & $\begin{array}{c}15.7-31.1 \\
(28)\end{array}$ \\
\hline & August & $\mathrm{NA}^{a}$ & NA & $\begin{array}{l}20.1 \\
(1.0)\end{array}$ & $\begin{array}{c}16.8-22.0 \\
(31)\end{array}$ \\
\hline & September & NA & NA & $\begin{array}{l}16.9 \\
(2.0)\end{array}$ & $\begin{array}{c}12.0-19.9 \\
(30)\end{array}$ \\
\hline & October & NA & NA & $\begin{array}{l}9.5 \\
(2.2)\end{array}$ & $\begin{array}{c}4.9-15.9 \\
(31)\end{array}$ \\
\hline & November & NA & NA & $\begin{array}{l}7.4 \\
(2.4)\end{array}$ & $\begin{array}{c}3.1-11.3 \\
(30)\end{array}$ \\
\hline & December & $\begin{array}{l}12.8 \\
(1.2)\end{array}$ & $\begin{array}{c}10.4-16.4 \\
\text { (12) }\end{array}$ & $\begin{array}{l}6.0 \\
(1.8)\end{array}$ & $\begin{array}{c}3.4-10.7 \\
(12)\end{array}$ \\
\hline \multirow[t]{9}{*}{1988} & January & $\begin{array}{l}9.9 \\
(1.4)\end{array}$ & $\begin{array}{c}5.6-13: 4 \\
(25)\end{array}$ & $\begin{array}{l}3.0 \\
(2.7)\end{array}$ & $\begin{array}{c}-(6.8)-4.3 \\
(25)\end{array}$ \\
\hline & February & $\begin{array}{l}11.4 \\
(1.7)\end{array}$ & $\begin{array}{c}7.6-16.5 \\
\text { (29) }\end{array}$ & $\begin{array}{l}4.5 \\
(2.4)\end{array}$ & $\begin{array}{c}0.6-10.1 \\
\text { (29) }\end{array}$ \\
\hline & March & $\begin{array}{l}13.1 \\
(2.1)\end{array}$ & $\begin{array}{c}8.3-21.8 \\
(31)\end{array}$ & $\begin{array}{l}7.9 \\
(3.9)\end{array}$ & $-\frac{(3.6)-18.0}{(31)}$ \\
\hline & April & $\begin{array}{l}16.6 \\
(1.9)\end{array}$ & $\begin{array}{c}12.3-21.9 \\
(30)\end{array}$ & $\begin{array}{l}12.4 \\
(2.7)\end{array}$ & $\begin{array}{c}6.1-19.7 \\
(30)\end{array}$ \\
\hline & May & $\begin{array}{l}20.1 \\
(2.0)\end{array}$ & $\begin{array}{c}14.4-24.6 \\
\text { (31) }\end{array}$ & $\begin{array}{l}14.9 \\
(2.8)\end{array}$ & $\begin{array}{c}7.4-20.9 \\
(31)\end{array}$ \\
\hline & June & $\begin{array}{l}24.3 \\
(1.9)\end{array}$ & $\begin{array}{c}19.1-29.5 \\
(30)\end{array}$ & $\begin{array}{l}18.3 \\
(3.0)\end{array}$ & $\begin{array}{c}11.4-25.3 \\
(30)\end{array}$ \\
\hline & July & $\begin{array}{l}25.3 \\
(1.9)\end{array}$ & $\begin{array}{c}19.6-32.2 \\
(26)\end{array}$ & $\begin{array}{l}20.8 \\
(2.1)\end{array}$ & $\begin{array}{c}14.7-25.6 \\
(26)\end{array}$ \\
\hline & August & $\begin{array}{l}26.7 \\
(1.2)\end{array}$ & $\begin{array}{c}23.1-29.9 \\
(26)\end{array}$ & $\begin{array}{l}21.3 \\
(1.4)\end{array}$ & $\begin{array}{c}16.8-24.1 \\
(26)\end{array}$ \\
\hline & September & $\begin{array}{l}23.9 \\
(1.3)\end{array}$ & $\begin{array}{c}20.4-28.3 \\
(30)\end{array}$ & $\begin{array}{l}18.3 \\
(2.0)\end{array}$ & $\begin{array}{c}12.7-23.5 \\
(30)\end{array}$ \\
\hline
\end{tabular}


Table A.6 (continued)

\begin{tabular}{|c|c|c|c|c|c|}
\hline \multicolumn{2}{|c|}{ Sampling period } & \multicolumn{2}{|c|}{ MIK 0.50} & \multicolumn{2}{|c|}{ GCK 2.4} \\
\hline Year & Month & Mean & Range & Mean & Range \\
\hline & October & $\begin{array}{l}18.3 \\
(2.3)\end{array}$ & $\begin{array}{c}13.6-24.9 \\
(31)\end{array}$ & $\begin{array}{l}10.3 \\
(3.7)\end{array}$ & $\begin{array}{c}2.6-21.4 \\
(31)\end{array}$ \\
\hline & November & $\begin{array}{l}14.7 \\
(1.5)\end{array}$ & $\begin{array}{c}10.8-19.1 \\
(30)\end{array}$ & $\begin{array}{l}8.8 \\
(2.0)\end{array}$ & $\begin{array}{c}4.1-13.1 \\
(30)\end{array}$ \\
\hline & December & $\begin{array}{l}11.3 \\
(1.2)\end{array}$ & $\begin{array}{c}5.8-14.5 \\
(31)\end{array}$ & $\begin{array}{l}3.7 \\
(2.7)\end{array}$ & $\begin{array}{c}-(0.2)-10.3 \\
(31)\end{array}$ \\
\hline \multirow[t]{12}{*}{1989} & January & $\begin{array}{l}10.6 \\
(1.3)\end{array}$ & $\begin{array}{l}5.7-14.2 \\
(20)\end{array}$ & $\begin{array}{l}7.2 \\
(1.8)\end{array}$ & $\begin{array}{c}2.5-10.7 \\
(20)\end{array}$ \\
\hline & February & $\begin{array}{l}10.9 \\
(2.6)\end{array}$ & $\begin{array}{c}5.9-16.6 \\
(16)\end{array}$ & $\begin{array}{l}7.3 \\
(2.2)\end{array}$ & $\begin{array}{c}1.7-13.8 \\
(28)\end{array}$ \\
\hline & March & NA & NA & $\begin{array}{l}10.2 \\
(2.5)\end{array}$ & $\begin{array}{c}4.9-18.1 \\
(31)\end{array}$ \\
\hline & April & NA & NA & $\begin{array}{l}12.1 \\
(2.5)\end{array}$ & $6.0-18.4$ \\
\hline & May & $\begin{array}{l}19.5 \\
(1.7)\end{array}$ & $\begin{array}{c}15.1-24.2 \\
(18)\end{array}$ & $\begin{array}{l}14.2 \\
(2.4)\end{array}$ & $\begin{array}{c}9.0-20.9 \\
(26)\end{array}$ \\
\hline & June & $\begin{array}{l}20.2 \\
(1.3)\end{array}$ & $\begin{array}{c}17.5-25.4 \\
(30)\end{array}$ & $\begin{array}{l}16.7 \\
(1.0)\end{array}$ & $\begin{array}{c}14.1-20.8 \\
(30)\end{array}$ \\
\hline & July & $\begin{array}{l}21.4 \\
(1.7)\end{array}$ & $\begin{array}{c}19.4-27.8 \\
(31)\end{array}$ & $\begin{array}{l}17.6 \\
(1.1)\end{array}$ & $\begin{array}{c}14.4-20.1 \\
(31)\end{array}$ \\
\hline & August & $\begin{array}{l}23.3 \\
(0.9)\end{array}$ & $\begin{array}{c}21.0-27.3 \\
(28)\end{array}$ & $\begin{array}{l}17.8 \\
(1.5)\end{array}$ & $\begin{array}{c}13.1-21.5 \\
(28)\end{array}$ \\
\hline & September & NA & NA & $\begin{array}{l}17.5 \\
(1.8)\end{array}$ & $\begin{array}{c}12.8-20.9 \\
(30)\end{array}$ \\
\hline & October & NA & NA & $\begin{array}{l}13.1 \\
(2.8)\end{array}$ & $\begin{array}{c}7.1-18.5 \\
(31)\end{array}$ \\
\hline & November & NA & NA & $\begin{array}{l}10.3 \\
(2.0)\end{array}$ & $\begin{array}{c}5.3-14.3 \\
(30)\end{array}$ \\
\hline & December & NA & NA & $\begin{array}{l}4.9 \\
(2.4)\end{array}$ & $\begin{array}{c}0.4-9.8 \\
(28)\end{array}$ \\
\hline \multirow[t]{4}{*}{1990} & January & $\begin{array}{l}10.5 \\
(1.0)\end{array}$ & $\begin{array}{c}8.0-12.5 \\
(12)\end{array}$ & $\begin{array}{l}7.5 \\
(1.6)\end{array}$ & $\begin{array}{c}2.9-11.1 \\
(31)\end{array}$ \\
\hline & February & $\begin{array}{l}11.6 \\
(1.5)\end{array}$ & $\begin{array}{c}7.7-16.7 \\
(28)\end{array}$ & $\begin{array}{l}9.4 \\
(1.7)\end{array}$ & $\begin{array}{c}4.6-12.8 \\
(28)\end{array}$ \\
\hline & March & $\begin{array}{l}13.1 \\
(1.8)\end{array}$ & $\begin{array}{c}9.2-18.1 \\
(31)\end{array}$ & $\begin{array}{l}10.7 \\
(2.1)\end{array}$ & $\begin{array}{c}5.9-16.6 \\
(31)\end{array}$ \\
\hline & April & $\begin{array}{l}15.7 \\
(2.6)\end{array}$ & $\begin{array}{c}9.8-24.1 \\
(30)\end{array}$ & $\begin{array}{l}12.7 \\
(1.8)\end{array}$ & $\begin{array}{c}10.0-16.6 \\
\text { (2) }\end{array}$ \\
\hline
\end{tabular}


Table A.6 (continued)

\begin{tabular}{|c|c|c|c|c|c|}
\hline \multicolumn{2}{|c|}{ Sampling Period } & \multicolumn{2}{|c|}{ MIK 0.50} & \multicolumn{2}{|c|}{ GCK 2.4} \\
\hline Year & Month & Mean & Range & Mean & Range \\
\hline & May & $\begin{array}{l}18.3 \\
(2.0)\end{array}$ & $\begin{array}{c}13.2-23.1 \\
(29)\end{array}$ & $\begin{array}{l}14.7 \\
(1.5)\end{array}$ & $\begin{array}{c}10.4-19.2 \\
\text { (29) }\end{array}$ \\
\hline & June & $\begin{array}{l}22.1 \\
(2.0)\end{array}$ & $\begin{array}{c}17.6-31.1 \\
(30)\end{array}$ & $\begin{array}{l}16.4 \\
(1.3)\end{array}$ & $\begin{array}{c}12.2-20.8 \\
(30)\end{array}$ \\
\hline & July & $\begin{array}{l}24.1 \\
(1.3)\end{array}$ & $\begin{array}{c}21.4-28.0 \\
(31)\end{array}$ & $\begin{array}{l}18.2 \\
(1.1)\end{array}$ & $\begin{array}{c}15.3-22.0 \\
(31)\end{array}$ \\
\hline & August & $\begin{array}{l}24.2 \\
(1.2)\end{array}$ & $\begin{array}{c}20.8-28.8 \\
(31)\end{array}$ & $\begin{array}{l}18.9 \\
(1.2)\end{array}$ & $\begin{array}{c}16.1-23.3 \\
(31)\end{array}$ \\
\hline & September & $\begin{array}{l}22.7 \\
(1.9)\end{array}$ & $\begin{array}{c}19.2-29.1 \\
(26)\end{array}$ & $\begin{array}{l}17.1 \\
(2.6)\end{array}$ & $\begin{array}{c}11.0-20.3 \\
(28)\end{array}$ \\
\hline & October & $\begin{array}{l}19.1 \\
(1.8)\end{array}$ & $\begin{array}{c}15.3-23.6 \\
(31)\end{array}$ & $\begin{array}{l}12.7 \\
(3.2)\end{array}$ & $\begin{array}{c}5.2-18.3 \\
(31)\end{array}$ \\
\hline & November & $\begin{array}{l}14.9 \\
(1.4)\end{array}$ & $\begin{array}{c}11.0-18.5 \\
(30)\end{array}$ & $\begin{array}{l}7.8 \\
(1.7)\end{array}$ & $\begin{array}{c}4.0-12.9 \\
(30)\end{array}$ \\
\hline & December & $\begin{array}{l}12.1 \\
(1.7)\end{array}$ & $\begin{array}{c}4.6-15.6 \\
(31)\end{array}$ & $\begin{array}{l}7.5 \\
(2.4)\end{array}$ & $\begin{array}{c}3.7-13.1 \\
(30)\end{array}$ \\
\hline \multirow[t]{2}{*}{1991} & January & $\begin{array}{l}10.4 \\
(1.5)\end{array}$ & $\begin{array}{c}6.4-14.4 \\
(31)\end{array}$ & $\begin{array}{l}7.8 \\
(2.1)\end{array}$ & $\begin{array}{c}1.9-11.0 \\
(31)\end{array}$ \\
\hline & February & $\begin{array}{l}9.9 \\
(2.1)\end{array}$ & $\begin{array}{c}3.0-15.3 \\
(28)\end{array}$ & $\begin{array}{l}7.6 \\
(2.2)\end{array}$ & $\begin{array}{c}2.3-12.1 \\
(28)\end{array}$ \\
\hline & March & $\begin{array}{l}12.6 \\
(2.0)\end{array}$ & $\begin{array}{c}8.5-18.5 \\
\text { (31) }\end{array}$ & $\begin{array}{l}10.5 \\
(2.2)\end{array}$ & $\begin{array}{c}5.6-15.8 \\
(31)\end{array}$ \\
\hline & April & $\begin{array}{l}16.3 \\
(1.8)\end{array}$ & $\begin{array}{c}10.5-21.3 \\
(28)\end{array}$ & $\begin{array}{l}13.3 \\
(2.0)\end{array}$ & $\begin{array}{c}8.5-17.8 \\
(16)\end{array}$ \\
\hline & May & $\begin{array}{l}20.5 \\
(2.1)\end{array}$ & $\begin{array}{c}14.5-26.5 \\
(31)\end{array}$ & & \\
\hline & June & $\begin{array}{l}23.1 \\
(1.2)\end{array}$ & $\begin{array}{c}20.2-26.5 \\
(30)\end{array}$ & & \\
\hline & July & $\begin{array}{l}24.4 \\
(0.8)\end{array}$ & $\begin{array}{c}22.3-28.8 \\
(31)\end{array}$ & & \\
\hline & August & $\begin{array}{l}24.7 \\
(0.6)\end{array}$ & $\begin{array}{c}22.9-27.5 \\
(30)\end{array}$ & & \\
\hline & September & $\begin{array}{l}23.2 \\
(2.0)\end{array}$ & $\begin{array}{c}18.1-26.4 \\
(30)\end{array}$ & & \\
\hline & \multirow[t]{2}{*}{ October } & 19.4 & $15.2-22.7$ & \multicolumn{2}{|c|}{ SCK 2.2} \\
\hline & & $(1.5)$ & (31) & Mean & Range \\
\hline & November & $\begin{array}{l}14.4 \\
(1.8)\end{array}$ & $\begin{array}{c}10.8-18.6 \\
(30)\end{array}$ & $\begin{array}{l}11.0 \\
(2.2)\end{array}$ & $\begin{array}{c}6.4-15.9 \\
(30)\end{array}$ \\
\hline
\end{tabular}


Table A.6 (continued)

\begin{tabular}{|c|c|c|c|c|c|}
\hline \multicolumn{2}{|c|}{ Sampling Period } & \multicolumn{2}{|c|}{ MIK 0.50} & \multicolumn{2}{|c|}{ SCK 2.2} \\
\hline Year & Month & Mean & Range & Mean & Range \\
\hline \multirow{3}{*}{1992} & December & $\begin{array}{l}12.6 \\
(1.5)\end{array}$ & $\begin{array}{c}9.8-17.3 \\
(12)\end{array}$ & $\begin{array}{l}11.6 \\
(1.0)\end{array}$ & $\begin{array}{c}9.0-15.0 \\
(29)\end{array}$ \\
\hline & January & NA & NA & $\begin{array}{l}10.6 \\
(1.2)\end{array}$ & $\begin{array}{c}7.8-13.2 \\
(31)\end{array}$ \\
\hline & February & NA & NA & $\begin{array}{l}10.5 \\
(1.2)\end{array}$ & $\begin{array}{c}6.5-13.3 \\
(29)\end{array}$ \\
\hline & March & NA & NA & $\begin{array}{l}10.7 \\
(0.8)\end{array}$ & $\begin{array}{c}8.5-12.3 \\
(10)\end{array}$ \\
\hline & April & $\mathrm{NA}$ & $\mathrm{NA}$ & $\begin{array}{l}13.9 \\
(1.9)\end{array}$ & $\begin{array}{c}10.4-18.1 \\
(7)\end{array}$ \\
\hline & May & $\begin{array}{l}19.0 \\
(5.8)\end{array}$ & $\begin{array}{c}8.6-40.1 \\
(31)\end{array}$ & $\begin{array}{l}15.5 \\
(1.5)\end{array}$ & $\begin{array}{c}11.6-19.6 \\
(31)\end{array}$ \\
\hline & June & $\begin{array}{l}21.5 \\
(1.7)\end{array}$ & $\begin{array}{c}12.5-28.9 \\
(30)\end{array}$ & NA & NA \\
\hline & July & $\begin{array}{l}23.8 \\
(1.2)\end{array}$ & $\begin{array}{c}21.0-26.9 \\
\text { (31) }\end{array}$ & NA & NA \\
\hline & August & $\begin{array}{l}24.2 \\
(5.2)\end{array}$ & $\begin{array}{c}16.1-45.0 \\
(30)\end{array}$ & $\begin{array}{l}17.4 \\
(1.0)\end{array}$ & $\begin{array}{c}15.0-19.6 \\
(18)\end{array}$ \\
\hline & September & $\begin{array}{l}22.7 \\
(5.2)\end{array}$ & $\begin{array}{c}10.0-42.7 \\
(30)\end{array}$ & $\begin{array}{l}17.1 \\
(1.1)\end{array}$ & $\begin{array}{c}12.6-19.6 \\
(30)\end{array}$ \\
\hline & October & $\begin{array}{l}15.8 \\
(5.1)\end{array}$ & $\begin{array}{c}5.7-39.2 \\
(31)\end{array}$ & $\begin{array}{l}13.8 \\
(1.5)\end{array}$ & $\begin{array}{c}9.0-16.8 \\
(31)\end{array}$ \\
\hline & November & $\begin{array}{l}14.4 \\
(1.6)\end{array}$ & $\begin{array}{c}10.5-19.9 \\
(30)\end{array}$ & $\begin{array}{l}11.7 \\
(1.8)\end{array}$ & $\begin{array}{c}8.0-16.8 \\
(30)\end{array}$ \\
\hline & December & $\begin{array}{l}11.6 \\
(0.9)\end{array}$ & $\begin{array}{c}8.5-13.5 \\
(20)\end{array}$ & $\begin{array}{l}9.8 \\
(1.3)\end{array}$ & $\begin{array}{c}6.3-13.1 \\
(25)\end{array}$ \\
\hline 1993 & January & $\begin{array}{l}11.1 \\
(1.1)\end{array}$ & $\begin{array}{c}8.0-13.9 \\
(31)\end{array}$ & $\begin{array}{l}11.1 \\
(0.9)\end{array}$ & $\begin{array}{c}8.0-13.5 \\
(31)\end{array}$ \\
\hline & February & $\begin{array}{l}10.6 \\
(2.2)\end{array}$ & $\begin{array}{c}5.6-15.7 \\
(28)\end{array}$ & $\begin{array}{l}10.0 \\
(1.3)\end{array}$ & $\begin{array}{c}6.3-13.3 \\
(28)\end{array}$ \\
\hline & March & $\begin{array}{l}10.8 \\
(2.1)\end{array}$ & $\begin{array}{c}5.2-17.1 \\
(30)\end{array}$ & $\begin{array}{l}11.0 \\
(1.7)\end{array}$ & $\begin{array}{c}5.6-15.6 \\
(30)\end{array}$ \\
\hline & April & $\begin{array}{l}14.0 \\
(2.0)\end{array}$ & $\begin{array}{c}10.0-19.0 \\
(29)\end{array}$ & $\begin{array}{l}13.3 \\
(1.5)\end{array}$ & $\begin{array}{c}10.5-17.4 \\
(28)\end{array}$ \\
\hline & May & $\begin{array}{l}19.0 \\
(1.9)\end{array}$ & $\begin{array}{c}14.6-24.4 \\
(31)\end{array}$ & $\begin{array}{l}15.2 \\
(1.4)\end{array}$ & $\begin{array}{c}11.8-20.2 \\
(31)\end{array}$ \\
\hline & June & $\begin{array}{l}21.8 \\
(1.7)\end{array}$ & $\begin{array}{c}16.8-25.4 \\
(30)\end{array}$ & $\begin{array}{l}16.6 \\
(1.2)\end{array}$ & $\begin{array}{c}13.5-19.1 \\
(30)\end{array}$ \\
\hline
\end{tabular}


Table A.6 (continued)

\begin{tabular}{|c|c|c|c|c|c|}
\hline \multicolumn{2}{|c|}{ Sampling Period } & \multicolumn{2}{|c|}{ MIK 0.50} & \multicolumn{2}{|c|}{ SCK 2.2} \\
\hline Year & Month & Mean & Range & Mean & Range \\
\hline & July & $\begin{array}{l}24.1 \\
(1.4)\end{array}$ & $\begin{array}{c}21.9-27.7 \\
(19)\end{array}$ & $\begin{array}{l}18.3 \\
(1.1)\end{array}$ & $\begin{array}{c}15.7-21.1 \\
(29)\end{array}$ \\
\hline & August & NA & $\mathrm{NA}$ & $\begin{array}{l}18.2 \\
(1.1)\end{array}$ & $\begin{array}{c}15.4-21.0 \\
(31)\end{array}$ \\
\hline & September & $\begin{array}{l}19.9 \\
(1.7)\end{array}$ & $\begin{array}{c}16.0-22.5 \\
\text { (9) }\end{array}$ & $\begin{array}{l}17.0 \\
(1.7)\end{array}$ & $\begin{array}{c}11.8-22.3 \\
(30)\end{array}$ \\
\hline & October & $\begin{array}{l}17.7 \\
(2.3)\end{array}$ & $\begin{array}{c}12.8-22.1 \\
(20)\end{array}$ & $\begin{array}{l}13.8 \\
(1.8)\end{array}$ & $\begin{array}{c}9.5-18.0 \\
(30)\end{array}$ \\
\hline & November & $\begin{array}{l}13.4 \\
(1.7)\end{array}$ & $\begin{array}{c}9.1-17.7 \\
(30)\end{array}$ & $\begin{array}{l}11.2 \\
(1.7)\end{array}$ & $\begin{array}{c}8.2-15.3 \\
(30)\end{array}$ \\
\hline & December & $\begin{array}{l}10.2 \\
(1.6)\end{array}$ & $\begin{array}{c}6.8-14.1 \\
(31)\end{array}$ & $\begin{array}{l}10.2 \\
(1.4)\end{array}$ & $\begin{array}{c}6.4-13.3 \\
(31)\end{array}$ \\
\hline 1994 & January & $\begin{array}{l}7.3 \\
(1.6)\end{array}$ & $\begin{array}{c}2.0-10.7 \\
(30)\end{array}$ & $\begin{array}{l}9.2 \\
(1.4)\end{array}$ & $\begin{array}{c}4.1-11.6 \\
(30)\end{array}$ \\
\hline & February & $\begin{array}{l}9.3 \\
(1.7)\end{array}$ & $\begin{array}{c}5.2-14.1 \\
(28)\end{array}$ & $\begin{array}{l}10.8 \\
(1.3)\end{array}$ & $\begin{array}{c}6.0-13.9 \\
(28)\end{array}$ \\
\hline & March & $\begin{array}{l}11.2 \\
(1.6)\end{array}$ & $\begin{array}{c}7.7-15.8 \\
(31)\end{array}$ & $\begin{array}{l}11.8 \\
(1.3)\end{array}$ & $\begin{array}{c}7.9-16.3 \\
(31)\end{array}$ \\
\hline
\end{tabular}

$\mathrm{NA}=$ no data available.

Note: Data were obtained with Ryan Tempmentor digital temperature recorders with values recorded every $20 \mathrm{~min}$, April-June, 1987 and every $60 \mathrm{~min}$ beginning July 1987. 
APPENDIX B

RESULTS OF AMBIENT TOXICITY TESTS AND WATER QUALITY MEASUREMENTS, JANUARY 1990 THROUGH JANUARY 1994 


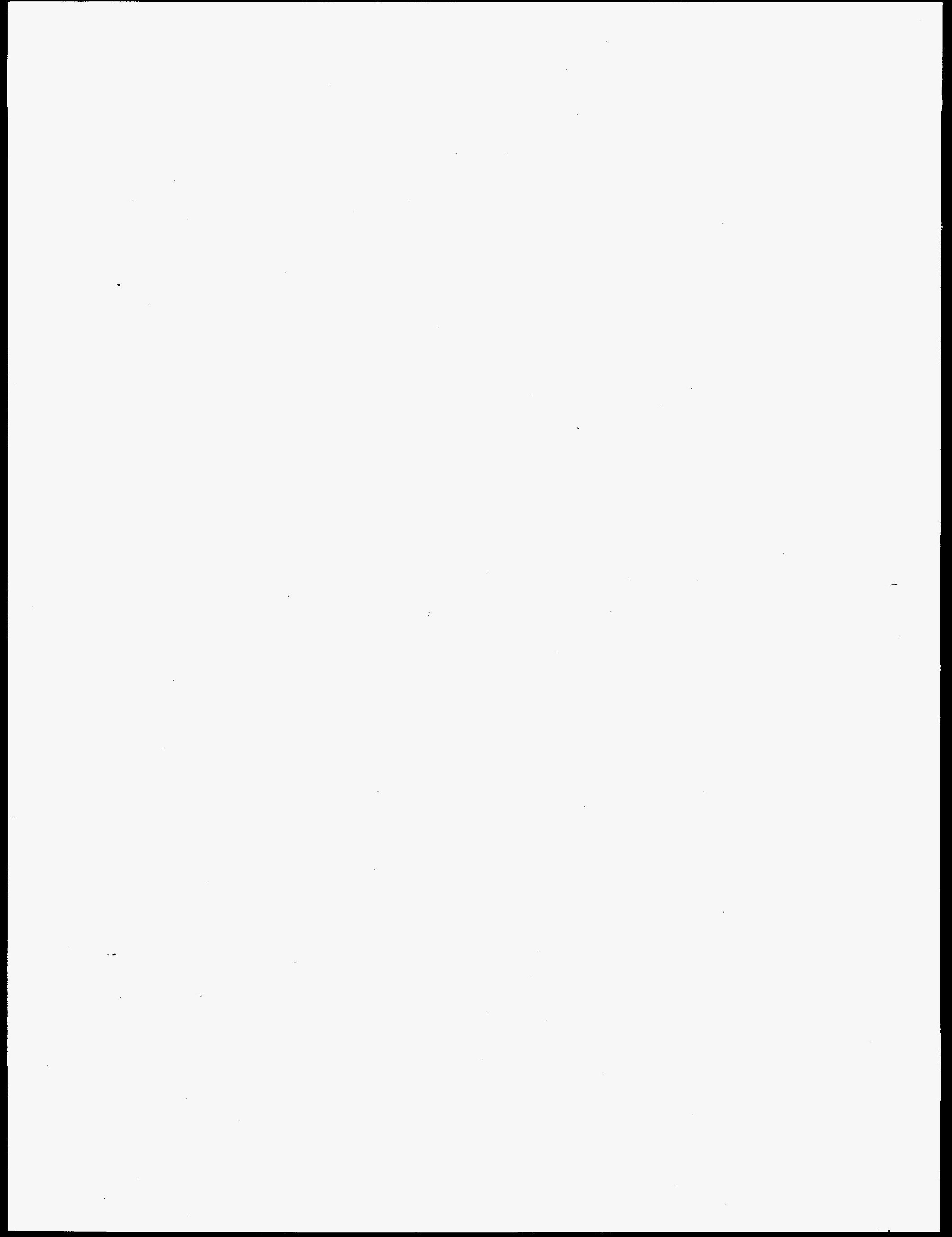


Table B.1. Summary (mean \pm SD) of water chemistry analyses conducted during toxicity tests of ambient waters from Mitchell Branch, Poplar Creek and Clinch River

\begin{tabular}{|c|c|c|c|c|c|}
\hline Sample $^{a}$ & Date & $\mathrm{pH}$ & $\begin{array}{c}\text { Alkalinity } \\
\left(\mathrm{mg} / \mathrm{L} \text { as } \mathrm{CaCO}_{3}\right)\end{array}$ & $\begin{array}{c}\text { Hardness } \\
\left(\mathrm{mg} / \mathrm{L} \text { as } \mathrm{CaCO}_{3}\right)\end{array}$ & $\begin{array}{l}\text { Conductivity } \\
(\mu \mathrm{S} / \mathrm{cm})\end{array}$ \\
\hline MIK 1.43 & Jan. 1990 & $7.5(0.2)$ & $48.3(5.5)$ & $64.3(5.5)$ & $110.1(15.3)$ \\
\hline MIK 1.00 & & $7.8(0.1)$ & $71.7(15.2)$ & $93.7(13.4)$ & $174.0(24.7)$ \\
\hline MIK 0.71 & & $7.8(0.1)$ & $81.9(23.9)$ & $125.7(26.5)$ & $268.6(101.9)$ \\
\hline MIK 0.54 & & $7.9(0.1)$ & $91.7(21.6)$ & $123.4(31.6)$ & 319.1 (122.3) \\
\hline MIK 0.45 & & $7.9(0.1)$ & $95.0(25.4)$ & $145.1(43.9)$ & $333.6(126.6)$ \\
\hline MIK 0.12 & & $7.9(0.1)$ & $102.6(33.1)$ & $148.6(37.3)$ & $357.6(140.3)$ \\
\hline MIK 1.43 & Mar. 1990 & $7.6(0.1)$ & $64.1(6.2)$ & $72.6(12.0)$ & $125.3(14.0)$ \\
\hline MIK 1.00 & & $7.9(0.1)$ & $96.9(5.5)$ & $110.6(10.4)$ & $200.0(10.1)$ \\
\hline MIK 0.71 & & $7.9(0.1)$ & $114.0(7.8)$ & $150.7(26.6)$ & 350.3 (121.9) \\
\hline MIK 0.54 & & $8.0(0.1)$ & $123.8(9.3)$ & $160.9(33.7)$ & 371.6 (119.3) \\
\hline MIIK 0.45 & & $7.9(0.1)$ & $129.4(9.4)$ & $179.7(29.2)$ & $392.4(110.8)$ \\
\hline MIK 0.12 & & $7.9(0.1)$ & $143.6(9.5)$ & $193.4(31.2)$ & $420.7(94.9)$ \\
\hline MIK 1.43 & May 1990 & $7.6(0.2)$ & $71.6(8.6)$ & $79.7(11.7)$ & $147.3(21.0)$ \\
\hline MIK 1.00 & & $7.9(0.2)$ & $107.1(17.5)$ & $120.3(19.4)$ & $222.4(37.2)$ \\
\hline MIK 0.71 & & $7.9(0.1)$ & $119.1(22.1)$ & $159.7(40.3)$ & 359.9 (123.2) \\
\hline MIK 0.54 & & $8.0(0.2)$ & $125.1(25.7)$ & $169.7(41.4)$ & $369.6(119.7)$ \\
\hline MIK 0.45 & & $7.9(0.1)$ & $124.6(34.9)$ & $173.4(48.8)$ & $373.6(135.9)$ \\
\hline MIK 0.12 & & $7.9(0.1)$ & $137.0(41.9)$ & $188.0(59.2)$ & $415.0(145.5)$ \\
\hline MIK 1.43 & July 1990 & $8.1(0.2)$ & $111.6(19.1)$ & $114.3(4.8)$ & $203.0(3.7)$ \\
\hline MIK 1.00 & & $8.0(0.1)$ & $144.4(15,9)$ & $169.1(7.4)$ & $321.1(15.1)$ \\
\hline MIK 0.71 & & $8.1(0.1)$ & $125.9(4.40$ & $158.9(4.7)$ & $336.7(21.2)$ \\
\hline MIK 0.54 & & $8.1(0.1)$ & $128.3(6.9)$ & $167.4(5.9)$ & $355.4(28.0)$ \\
\hline MIK 0.45 & & $8.1(0.1)$ & $122.6(7.1)$ & $164.3(8.0)$ & $344.3(18.7)$ \\
\hline MIK 0.12 & & $8.0(0.1)$ & $134.1(9.9)$ & $193.1(28.1)$ & $433.4(115.3)$ \\
\hline MIK 1.43 & Sep. 1990 & $8.0(0.1)$ & $111.4(4.1)$ & $123.7(9.6)$ & $215.4(8.3)$ \\
\hline MIK 1.00 & & $7.9(0.1)$ & $163.7(11.8)$ & $192.6(14.8)$ & $351.4(20.7)$ \\
\hline MIK 0.71 & & $8.1(0.1)$ & $120.3(4.2)$ & $156.6(5.3)$ & $333.7(12.7)$ \\
\hline MIK 0.54 & & $8.1(0.1)$ & $125.6(4.2)$ & $172.6(24.9)$ & $383.9(112.0)$ \\
\hline MIK 0.45 & & $8.0(0.1)$ & $122.4(4.0)$ & $171.6(24.8)$ & $378.4(98.5)$ \\
\hline MKK 0.12 & & $8.0(0.1)$ & $130.7(3.9)$ & $179.4(13.5)$ & $394.0(56.2)$ \\
\hline MIK 1.43 & Nov. 1990 & $7.7(0.2)$ & $100.7(13.3)$ & 106.9 (11.8) & $193.4(10.6)$ \\
\hline MIK 1.00 & & $7.8(0.1)$ & $135.9(25.6)$ & $154.9(27.8)$ & $302.3(43.6)$ \\
\hline MIK 0.71 & & $8.0(0.1)$ & $127.6(17.9)$ & $156.9(18.0)$ & $364.3(50.2)$ \\
\hline MIK 0.54 & & $8.0(0.1)$ & $134.3(20.0)$ & $175.1(21.0)$ & $385.4(70.4)$ \\
\hline MIK 0.45 & & $8.0(0.1)$ & $132.4(20.3)$ & $171.4(21.6)$ & $368.9(51.4)$ \\
\hline
\end{tabular}


Table B.1 (continued)

\begin{tabular}{|c|c|c|c|c|c|}
\hline Sample $^{a}$ & Date & $\mathrm{pH}$ & $\begin{array}{c}\text { Alkalinity } \\
\left(\mathrm{mg} / \mathrm{L} \text { as } \mathrm{CaCO}_{3}\right)\end{array}$ & $\begin{array}{c}\text { Hardness } \\
\left(\mathrm{mg} / \mathrm{L} \text { as } \mathrm{CaCO}_{3}\right)\end{array}$ & $\begin{array}{l}\text { Conductivity } \\
(\mu \mathrm{S} / \mathrm{cm})\end{array}$ \\
\hline MIK 0.12 & & $8.0(0.1)$ & $136.1(21.9)$ & $186.3(47.1)$ & $454.3(150.8)$ \\
\hline MIK 1.43 & Jan. 1991 & $7.5(0.2)$ & $62.4(3.5)$ & $78.3(6.3)$ & $138.0(5.6)$ \\
\hline MIK 1.00 & & $7.8(0.1)$ & $97.1(2.9)$ & $121.1(9.2)$ & $211.4(9.5)$ \\
\hline MIK 0.71 & & $7.9(0.1)$ & $118.0(10.1)$ & $155.1(13.4)$ & $313.1(41.8)$ \\
\hline MIIX 0.54 & & $8.0(0.1)$ & $126.7(12.1)$ & $172.3(15.6)$ & $340.3(46.3)$ \\
\hline MIK 0.45 & & $8.1(0.1)$ & $135.9(15.0)$ & $184.6(21.4)$ & $374.9(43.9)$ \\
\hline MIK 0.12 & & $8.1(0.1)$ & $144.3(26.6)$ & $251.1(149.3)$ & $557.3(431.8)$ \\
\hline MIK 1.43 & Mar. 1991 & $7.6(0.1)$ & $56.6(2.4)$ & $64.9(3.4)$ & $147.6(19.5)$ \\
\hline MIK 1.00 & & $7.8(0.1)$ & $76.9(20.4)$ & $90.9(15.6)$ & $203.9(34.4)$ \\
\hline MIK 0.71 & & $7.8(0.10$ & $96.7(20.6)$ & $113.4(24.7)$ & $262.7(56.5)$ \\
\hline MIK 0.54 & & $7.8(0.1)$ & $104.6(25.2)$ & $122.3(29.9)$ & $286.4(65.2)$ \\
\hline MIK 0.45 & & $7.8(0.1)$ & $105.9(36.5)$ & $129.9(44.6)$ & $295.9(96.6)$ \\
\hline MTK 0.12 & & $7.8(0.2)$ & $101.9(47.9)$ & $148.6(52.9)$ & $349.6(161.5)$ \\
\hline MIK 1.43 & May 1991 & $7.8(0.1)$ & $95.4(2.4)$ & $119.4(32.9)$ & $199.3(2.2)$ \\
\hline MIK 1.00 & & $7.9(0.2)$ & $130.7(2.8)$ & $160.6(38.6)$ & $284.1(9.8)$ \\
\hline MIK 0.71 & & $7.9(0.1)$ & $147.4(7.4)$ & $180.0(12.7)$ & $375.0(14.9)$ \\
\hline MIK 0.54 & & $7.9(0.1)$ & $151.3(8.9)$ & $188.6(7.2)$ & $401.3(13.4)$ \\
\hline MIK 0.45 & & $7.9(0.1)$ & $169.3(63.6)$ & $181.7(7.7)$ & $384.4(13.6)$ \\
\hline MIK 0.12 & & $8.0(0.1)$ & $149.3(13.9)$ & $194.0(14.1)$ & $399.1(29.6)$ \\
\hline MIK 1.43 & July 1991 & $7.7(0.2)$ & $108.9(2.8)$ & $112.7(4.2)$ & $201.3(7.2)$ \\
\hline MIK 1.00 & & $7.8(0.2)$ & $151.0(25.3)$ & $162.6(27.6)$ & $294.6(40.7)$ \\
\hline MIK 0.71 & & $7.8(0.2)$ & $126.0(20.4)$ & $165.7(27.7)$ & $336.7(56.7)$ \\
\hline MIK 0.54 & & $7.8(0.2)$ & $125.6(22.4)$ & $162.0(29.8)$ & $333.1(58.0)$ \\
\hline MIK 0.45 & & $7.7(0.2)$ & $120.4(28.4)$ & $159.7(36.2)$ & $326.1(74.2)$ \\
\hline MIK 0.12 & & $7.7(0.3)$ & $135.7(3.7)$ & $176.9(5.2)$ & $360.1(15.9)$ \\
\hline MIK 1.43 & Sep. 1991 & $7.7(0.2)$ & $121.7(6.4)$ & $135.7(13.0)$ & $224.4(14.3)$ \\
\hline MIK 1.00 & & $-(-)$ & $-(-)$ & $--(--)$ & $-(--)$ \\
\hline MIK 0.71 & & $7.8(0.1)$ & $114.0(5.0)$ & $155.7(4.2)$ & $337.1(6.3)$ \\
\hline MIK 0.54 & & $7.8(0.1)$ & $119.0(4.0)$ & 164.9 (11.6) & $327.9(16.4)$ \\
\hline MIK 0.45 & & $7.8(0.1)$ & $119.3(4.0)$ & $158.9(10.7)$ & $322.4(11.8)$ \\
\hline MIK 0.12 & & $7.7(0.1)$ & $127.0(2.8)$ & $176.0(15.0)$ & 344.1 (17.9) \\
\hline MIK 1.43 & Nov. 1991 & $7.6(0.2)$ & $97.7(18.2)$ & $112.6(21.1)$ & $191.4(26.5)$ \\
\hline MIK 1.00 & & $7.6(0.2)$ & $134.1(32.2)$ & $169.0(34.60$ & $307.9(51.8)$ \\
\hline MIK 0.71 & & $7.7(0.2)$ & $131.9(25.2)$ & $176.9(24.7)$ & $344.3(58.4)$ \\
\hline MIK 0.54 & & $7.7(0.2)$ & $139.0(28.0)$ & $187.4(30.4)$ & $356.0(56.5)$ \\
\hline MIK 0.45 & & $7.8(0.2)$ & $132.4(22.9)$ & $178.0(25.6)$ & $347.3(50.7)$ \\
\hline
\end{tabular}


Table B.1 (continued)

\begin{tabular}{|c|c|c|c|c|c|}
\hline Sample ${ }^{a}$ & Date & pH & $\begin{array}{c}\text { Alkalinity } \\
\text { (mg/L as } \mathrm{CaCO}_{3} \text { ) }\end{array}$ & $\begin{array}{c}\text { Hardness } \\
\left.\text { (mg/L as } \mathrm{CaCO}_{3}\right)\end{array}$ & $\begin{array}{l}\text { Conductivity } \\
(\mu \mathrm{S} / \mathrm{cm})\end{array}$ \\
\hline MIK 0.12 & & $7.7(0.2)$ & $137.3(34.2)$ & $186.0(42.6)$ & $353.0(81.8)$ \\
\hline MIK 1.43 & Jan. 1992 & $7.7(0.1)$ & $61.9(6.8)$ & $83.1(19.7)$ & $123.9(13.8)$ \\
\hline MIK 1.00 & & $8.0(0.1)$ & $92.7(8.1)$ & $106.6(13.2)$ & $192.6(15.0)$ \\
\hline MIK 0.71 & & $8.0(0.1)$ & $112.6(5.7)$ & $136.6(14.6)$ & $265.1(17.0)$ \\
\hline MIK 0.54 & & $8.0(0.1)$ & $123.6(6.8)$ & $151.7(10.4)$ & $289.4(20.2)$ \\
\hline MIK 0.45 & & $8.0(0.1)$ & $127.9(6.4)$ & $165.4(14.8)$ & $311.4(21.6)$ \\
\hline MIK 0.12 & & $8.0(0.1)$ & $139.9(7.4)$ & $178.0(9.4)$ & $334.1(22.1)$ \\
\hline MIK 1.43 & Mar. 1992 & $7.7(0.1)$ & $59.1(2.0)$ & $70.9(9.9)$ & $126.0(4.7)$ \\
\hline MIK 1.00 & & $8.0(0.1)$ & $89.7(3.3)$ & $102.0(6.2)$ & $196.3(6.5)$ \\
\hline MIK 0.71 & & $8.0(0.1)$ & $108.0(4.7)$ & $133.1(5.5)$ & $265.4(9.3)$ \\
\hline MIK 0.54 & & $8.0(0.1)$ & $118.9(4.9)$ & $150.0(6.9)$ & $296.4(14.9)$ \\
\hline MIK 0.45 & & $8.0(0.1)$ & $121.9(3.5)$ & $156.9(10.3)$ & $310.7(14.1)$ \\
\hline MKK 0.12 & & $8.0(0.1)$ & $129.6(11.8)$ & $161.7(17.1)$ & $324.6(27.4)$ \\
\hline MIK 1.43 & May 1992 & $8.1(0.1)$ & $95.1(6.2)$ & $108.0(8.2)$ & $176.6(11.6)$ \\
\hline MIK 1.00 & & $8.1(0.1)$ & $132.7(7.2)$ & $149.7(3.9)$ & $255.9(14.8)$ \\
\hline MIK 0.71 & & $8.1(0.1)$ & $130.1(8.3)$ & $173.4(7.4)$ & $329.7(17.2)$ \\
\hline MK 0.54 & & $8.1(0.1)$ & $139.7(4.8)$ & $184.3(7.8)$ & $348.1(16.1)$ \\
\hline MIK 0.45 & & $8.1(0.1)$ & $129.6(6.1)$ & $177.4(8.0)$ & 339.7 (19.5) \\
\hline MIK 0.12 & & $8.0(0.2)$ & $138.3(5.8)$ & $185.7(4.7)$ & $353.7(23.5)$ \\
\hline MIK 1.43 & July 1992 & $8.1(0.1)$ & $114.1(4.6)$ & $120.9(8.1)$ & $205.7(10.5)$ \\
\hline $\mathrm{MIK} 1.00$ & & $8.2(0.1)$ & $160.9(12.7)$ & $175.1(11.1)$ & $310.6(16.2)$ \\
\hline MIK 0.71 & & $8.1(0.1)$ & $128.7(5.2)$ & $171.1(9.9)$ & $341.1(21.8)$ \\
\hline MIK 0.54 & & $8.2(0.1)$ & $136.1(6.0)$ & $175.1(8.1)$ & $356.1(20.3)$ \\
\hline MIK 0.45 & & $8.1(0.1)$ & $125.6(3.3)$ & $168.3(6.4)$ & $350.1(14.7)$ \\
\hline MIK 0.12 & & $8.0(0.2)$ & $127.4(17.6)$ & $168.0(26.3)$ & $348.1(50.2)$ \\
\hline MIK 1.43 & Sep. 1992 & $8.1(0.2)$ & $117.6(4.7)$ & $127.1(8.6)$ & $223.3(11.7)$ \\
\hline MIK 1.00 & & $8.1(0.2)$ & $159.4(35.3)$ & $182.6(40.6)$ & $336.0(57.5)$ \\
\hline MIK 0.71 & & $8.1(0.1)$ & $133.3(20.9)$ & $176.6(32.9)$ & $360.7(59.0)$ \\
\hline MIK 0.54 & & $8.1(0.1)$ & $138.4(24.4)$ & $183.4(39.0)$ & $364.4(69.5)$ \\
\hline MIK 0.45 & & $8.1(0.1)$ & $139.4(29.1)$ & $189.7(46.2)$ & $381.4(83.0)$ \\
\hline MIK 0.12 & & $8.0(0.1)$ & $148.0(40.8)$ & $189.1(59.1)$ & $392.1(105.5)$ \\
\hline MIK 1.43 & Nov. 1992 & $8.0(0.2)$ & $103.7(4.5)$ & $112.3(9.3)$ & $207.0(5.9)$ \\
\hline MIK 1.00 & & $8.1(0.1)$ & $139.4(21.7)$ & $163.7(24.4)$ & $314.1(48.0)$ \\
\hline MK 0.71 & & $8.1(0.1)$ & $131.7(16.3)$ & $168.9(23.9)$ & 341.7 (41.9) \\
\hline MIK 0.54 & & $8.1(0.2)$ & $139.3(19.8)$ & $174.0(26.8)$ & $361.6(56.4)$ \\
\hline MIK 0.45 & & $8.1(0.1)$ & $146.7(27.7)$ & $193.1(40.6)$ & $388.4(70.3)$ \\
\hline
\end{tabular}


Table B.1 (continued)

\begin{tabular}{|c|c|c|c|c|c|}
\hline Sample $^{a}$ & Date & $\mathrm{pH}$ & $\begin{array}{c}\text { Alkalinity } \\
\left(\mathrm{mg} / \mathrm{L} \text { as } \mathrm{CaCO}_{3}\right)\end{array}$ & $\begin{array}{c}\text { Hardness } \\
\left(\mathrm{mg} / \mathrm{L} \text { as } \mathrm{CaCO}_{3}\right)\end{array}$ & $\begin{array}{l}\text { Conductivity } \\
(\mu \mathrm{S} / \mathrm{cm})\end{array}$ \\
\hline MIK 1.43 & Feb. 1993 & $7.7(0.2)$ & $51.4(7.5)$ & $70.3(12.0)$ & $115.6(14.8)$ \\
\hline MIK 1.00 & & $7.9(0.1)$ & $71.7(14.5)$ & $93.4(15.1)$ & $165.9(24.4)$ \\
\hline MIK 0.71 & & $8.0(0.1)$ & $86.3(20.3)$ & $121.4(15.4)$ & $222.1(41.1)$ \\
\hline MIK 0.54 & & $8.1(0.1)$ & $95.6(22.8)$ & $123.4(24.6)$ & $227.7(52.7)$ \\
\hline MIK 0.45 & & $8.1(0.2)$ & $100.7(28.4)$ & $.136 .0(31.1)$ & $261.6(65.0)$ \\
\hline MIK 0.12 & & $8.1(0.2)$ & $110.0(32.8)$ & $147.4(42.4)$ & $279.7(72.5)$ \\
\hline MIK 0.12 & & $8.1(0.3)$ & $164.1(18.7)$ & $209.4(22.2)$ & $420.9(51.3)$ \\
\hline MIK 1.43 & Apr. 1993 & $7.8(0.3)$ & $60.4(2.9)$ & $78.3(6.8)$ & $130.3(4.4)$ \\
\hline MIK 0.78 & & $8.0(0.2)$ & $102.9(5.8)$ & $133.1(18.1)$ & $219.1(27.2)$ \\
\hline MIK 0.71 & & $8.1(0.1)$ & $101.3(5.3)$ & $140.6(19.1)$ & $250.7(31.0)$ \\
\hline MIK 0.54 & & $8.1(0.1)$ & $111.1(6.3)$ & $145.4(9.7)$ & $281.9(7.4)$ \\
\hline MIK 0.45 & & $8.1(0.1)$ & $117.4(8.6)$ & $172.9(28.4)$ & $310.6(9.3)$ \\
\hline MIK 0.12 & & $8.2(0.1)$ & $125.4(11.4)$ & $178.0(38.5)$ & $331.3(14.0)$ \\
\hline PCK 18.2 & & $7.9(0.1)$ & $46.3(4.5)$ & $84.0(6.0)$ & $166.3(6.4)$ \\
\hline PCK 8.2 & & $8.0(0.1)$ & $57.3(4.9)$ & $92.7(3.1)$ & $187.3(18.8)$ \\
\hline PCK 6.9 & & $8.1(0.1)$ & $60.3(6.5)$ & $130.7(68.9)$ & $197.3(16.0)$ \\
\hline PCK 4.7 & & $8.0(0.1)$ & $66.3(9.9)$ & $106.0(15.1)$ & $209.7(24.0)$ \\
\hline PCK 1.6 & & $8.0(0.1)$ & $64.0(7.2)$ & $120.7(34.2)$ & $205.3(13.3)$ \\
\hline CRK 15.0 & & $8.0(0.1)$ & $101.7(5.8)$ & $150.0(19.1)$ & $254.3(7.8)$ \\
\hline MIK 1.43 & July 1993 & $8.1(0.1)$ & $110.0(2.2)$ & $125.4(14.2)$ & $205.0(5.2)$ \\
\hline MIK 0.78 & & $8.0(0.1)$ & $192.3(9.1)$ & $215.7(25.7)$ & $386.4(25.2)$ \\
\hline MIK 0.71 & & $8.2(0.1)$ & $125.0(5.4)$ & $181.1(18.0)$ & $350.4(15.8)$ \\
\hline MIK 0.54 & & $8.1(0.1)$ & $135.6(6.8)$ & $184.3(12.3)$ & $370.9(1.5)$ \\
\hline MIK 0.45 & & $8.0(0.1)$ & $141.9(4.1)$ & $192.3(10.1)$ & $398.9(8.0)$ \\
\hline MIK 0.12 & & $7.9(0.1)$ & $145.4(3.8)$ & $208.3(17.3)$ & $410.6(6.1)$ \\
\hline PCK 18.2 & & $8.0(0.1)$ & $140.3(4.5)$ & $176.7(13.6)$ & $325.3(4.7)$ \\
\hline PCK 8.2 & & $8.1(0.1)$ & $128.0(3.0)$ & $183.3(26.6)$ & $335.3(3.5)$ \\
\hline PCK 6.9 & & $8.2(0.1)$ & $127.3(2.1)$ & $183.3(16.2)$ & $329.3(19.4)$ \\
\hline PCK 4.7 & & $8.2(0.2)$ & $122.0(2.0)$ & $174.7(31.3)$ & $335.7(7.6)$ \\
\hline PCK 1.6 & & $8.2(0.2)$ & $113.7(3.5)$ & $147.3(7.0)$ & $268.0(28.2)$ \\
\hline CRK 15.0 & & $8.1(0.2)$ & $112.0(2.0)$ & $158.7(23.7)$ & $253.3(15.0)$ \\
\hline MIK 1.43 & Oct. 1993 & $8.0(0.1)$ & $117.4(4.1)$ & $129.7(17.9)$ & $253.3(62.7)$ \\
\hline MIK 0.78 & & $7.9(0.1)$ & $184.1(6.4)$ & $206.0(23.2)$ & $418.9(81.6)$ \\
\hline MIK 0.71 & & $8.0(0.2)$ & $123.9(30.6)$ & $173.7(42.9)$ & $358.1(106.3)$ \\
\hline MIK 0.54 & & $8.0(0.1)$ & $131.3(31.6)$ & $167.4(38.7)$ & $374.7(110.8)$ \\
\hline MIK 0.45 & & $7.9(0.1)$ & $139.7(40.6)$ & $196.6(44.0)$ & $397.0(129.5)$ \\
\hline
\end{tabular}


Table B.1 (continued)

\begin{tabular}{|c|c|c|c|c|c|}
\hline Sample ${ }^{a}$ & Date & $\mathrm{pH}$ & $\begin{array}{c}\text { Alkalinity } \\
\left(\mathrm{mg} / \mathrm{L} \text { as } \mathrm{CaCO}_{3}\right)\end{array}$ & $\begin{array}{c}\text { Hardness } \\
\left.\text { (mg/L as } \mathrm{CaCO}_{3}\right)\end{array}$ & $\begin{array}{l}\text { Conductivity } \\
(\mu \mathrm{S} / \mathrm{cm})\end{array}$ \\
\hline MIK 0.12 & & $7.8(0.1)$ & $152.9(11.1)$ & $207.1(17.3)$ & $433.7(78.3)$ \\
\hline PCK 18.2 & & $7.8(0.1)$ & $140.7(3.8)$ & $180.0(22.7)$ & $337.0(70.9)$ \\
\hline PCK 8.2 & & $7.8(0.1)$ & $132.0(3.5)$ & $192.7(32.1)$ & $375.0(71.4)$ \\
\hline PCK 6.9 & & $7.7(0.1)$ & $129.0(4.4)$ & $189.3(26.1)$ & $376.3(76.5)$ \\
\hline PCK 4.7 & & $7.8(0.0)$ & $124.7(4.9)$ & $175.3(28.1)$ & $311.7(57.7)$ \\
\hline PCK 1.6 & & $8.2(0.1)$ & $123.3(3.1)$ & $165.3(15.0)$ & $326.0(65.5)$ \\
\hline CRK 15.0 & & $8.0(0.2)$ & $120.0(3.6)$ & $158.0(29.9)$ & $296.0(7.0)$ \\
\hline MIK 1.43 & Jan. 1994 & $7.8(0.2)$ & $45.7(8.8)$ & $61.4(7.6)$ & $118.7(17.1)$ \\
\hline MIK 0.78 & & $7.9(0.1)$ & $82.0(15.1)$ & $100.0(15.1)$ & $225.9(44.4)$ \\
\hline MIK 0.71 & & $8.0(0.1)$ & $86.0(10.6)$ & $112.6(13.8)$ & $257.0(36.2)$ \\
\hline MaK 0.54 & & $8.1(0.1)$ & $96.9(13.6)$ & $130.6(15.8)$ & $295.0(52.0)$ \\
\hline MIK 0.45 & & $8.1(0.1)$ & $102.6(13.5)$ & $140.3(22.0)$ & $333.1(86.3)$ \\
\hline MIK 0.12 & & $8.0(0.1)$ & $114.3(18.1)$ & $147.1(30.3)$ & $341.9(47.2)$ \\
\hline PCK 18.2 & & $7.4(0.2)$ & $41.0(16.0)$ & $73.3(20.1)$ & $172.3(39.1)$ \\
\hline PCK 8.2 & & $7.7(0.3)$ & $47.7(15.8)$ & $91.3(32.0)$ & $193.3(50.7)$ \\
\hline PCK 6.9 & & $7.7(0.3)$ & $53.7(16.5)$ & $86.7(19.0)$ & $202.0(49.0)$ \\
\hline PCK 4.7 & & $7.6(0.4)$ & $55.3(17.6)$ & $84.7(23.0)$ & $208.3(49.5)$ \\
\hline PCK 1.6 & & $7.5(0.3)$ & $60.0(14.0)$ & $90.0(22.5)$ & $226.3(56.5)$ \\
\hline CRK 15.0 & & $7.8(0.2)$ & $101.3(5.5)$ & $124.0(6.9)$ & $259.7(8.4)$ \\
\hline
\end{tabular}

${ }^{{ }^{2} \mathrm{MIK}}=$ Mitchell Branch kilometer, $\mathrm{PCK}=$ Poplar Creek kilometer, $\mathrm{CRK}=$ Clinch River kilometer. 
Table B.2. Results of toxicity tests of ambient samples from Mitchell Branch, Poplar Creek and Clinch River. Asterisks (*) indicate concentrations that are significantly different from control $(\alpha=0.05)$

\begin{tabular}{|c|c|c|c|c|c|}
\hline \multirow[b]{2}{*}{ Sample ${ }^{\mathrm{a}}$} & \multirow[b]{2}{*}{ Date } & \multicolumn{2}{|c|}{ Fathead Minnow } & \multicolumn{2}{|c|}{ Ceriodaphnia dubia } \\
\hline & & $\begin{array}{l}\text { Mean survival } \\
(\%)\end{array}$ & $\begin{array}{l}\text { Mean (SD) growth } \\
\text { (mg/fish) }\end{array}$ & $\begin{array}{l}\text { Survival } \\
\text { (\%) }\end{array}$ & $\begin{array}{c}\text { Mean (SD) offspring/surviving } \\
\text { female }\end{array}$ \\
\hline Control & Jan. 1990 & 97.5 & $0.42(0.04)$ & 80 & $20.8(4.1)$ \\
\hline MIK 1.43 & & 50.0 & $0.34(0.01)$ & 90 & $19.0(5.5)$ \\
\hline MIK 1.00 & & 60.0 & $0.39(0.02)$ & 100 & $19.9(1.6)$ \\
\hline Mm 0.71 & & 100.0 & $0.40(0.02)$ & 90 & $15.4(6.8)$ \\
\hline MIK 0.54 & & 97.5 & $0.39(0.04)$ & 90 & $14.0(6.8)$ \\
\hline MIK 0.45 & & 100.0 & $0.38(0.05)$ & 100 & $17.8(1.7)$ \\
\hline MIK 0.12 & & 90.0 & $0.39(0.05)$ & 100 & $19.6(3.8)$ \\
\hline Control & Mar. 1990 & 92.5 & $0.58(0.04)$ & 100 & $17.6(5.0)$ \\
\hline MIK 1.43 & & $12.5^{*}$ & $0.58(--)$ & 90 & $20.2(2.7)$ \\
\hline MIK 1.00 & & $17.5^{*}$ & $0.50(0.06)$ & 80 & $21.8(4.6)$ \\
\hline MaK 0.71 & & 90.0 & $0.62(0.03)$ & $20^{*}$ & $10.0(7.1)^{*}$ \\
\hline MIK 0.54 & & 87.5 & $0.56(0.12)$ & 70 & $9.3(4.9)^{*}$ \\
\hline MIK 0.45 & & 95.0 & $0.61(0.04)$ & $0^{*}$ & $-(-)$ \\
\hline MIK 0.12 & & 72.5 & $0.67(0.04)$ & 90 & $13.0(7.7)$ \\
\hline Control & May 1990 & 100.0 & $0.50(0.08)$ & 100 & $21.9(3.6)$ \\
\hline MIK 1.43 & & 82.5 & $0.50(0.09)$ & 90 & $24.0(4.0)$ \\
\hline MIK 1.00 & & $55.0^{*}$ & $0.59(0.09)$ & 100 & $28.1(3.7)$ \\
\hline MIK 0.71 & & 95.0 & $0.56(0.07)$ & 100 & $28.5(4.0)$ \\
\hline MIK 0.54 & & 95.0 & $0.64(0.02)$ & 100 & $22.6(6.6)$ \\
\hline MIK 0.45 & & 95.0 & $0.56(0.08)$ & 100 & $25.3(6.8)$ \\
\hline MIK 0.12 & & 100.0 & $0.60(0.08)$ & 80 & $19.0(8.4)$ \\
\hline Control & July 1990 & 97.5 & $0.58(0.06)$ & 70 & $10.9(5.9)$ \\
\hline MIK 1.43 & & 50.0 & $0.56(0.07)$ & 100 & $28.5(6.2)$ \\
\hline MIK 1.00 & & 87.5 & $0.59(0.08)$ & 100 & $32.2(9.5)$ \\
\hline MIK 0.71 & & 95.0 & $0.61(0.07)$ & $0^{*}$ & $-(-)$ \\
\hline MIK 0.54 & & 92.5 & $0.67(0.08)$ & $0^{*}$ & $-(-\infty)$ \\
\hline MIK 0.45 & & 90.0 & $0.67(0.08)$ & $0^{*}$ & $\cdots(--)$ \\
\hline MIK 0.12 & & 92.5 & $0.65(0.08)$ & 100 & $26.0(4.7)$ \\
\hline Control & Sep. 1990 & 100.0 & $0.57(0.07)$ & 90 & $39.1(10.6)$ \\
\hline MIK 1.43 & & 92.5 & $0.53(0.05)$ & 100 & $42.8(10.9)$ \\
\hline MIK 1.00 & & 92.5 & $0.56(0.09)$ & 90 & $45.2(5.0)$ \\
\hline
\end{tabular}


Table B.2 (continued)

\begin{tabular}{|c|c|c|c|c|c|}
\hline \multirow[b]{2}{*}{ Sample ${ }^{\mathrm{a}}$} & \multirow[b]{2}{*}{ Date } & \multicolumn{2}{|c|}{ Fathead Minnow } & \multicolumn{2}{|c|}{ Ceriodaphnia dubia } \\
\hline & & $\begin{array}{c}\text { Mean survival } \\
(\%)\end{array}$ & $\begin{array}{l}\text { Mean (SD) growth } \\
\text { (mg/fish) }\end{array}$ & $\begin{array}{l}\text { Survival } \\
(\%)\end{array}$ & $\begin{array}{c}\text { Mean (SD) offspring/surviving } \\
\text { female }\end{array}$ \\
\hline MIK 0.71 & & -- & $\cdots(--)$ & - & $-(--)$ \\
\hline MIK 0.54 & & 100.0 & $0.62(0.07)$ & $0^{*}$ & $-(-)$ \\
\hline MIK 0.45 & & $0.0^{*}$ & $-(-)$ & $0^{*}$ & $-(--)$ \\
\hline MIK 0.12 & & 100.0 & $0.62(0.08)$ & 100 & $32.2(12.2)$ \\
\hline Control & Nov. 1990 & 75.0 & $0.59(0.04)$ & 100 & $28.0(2.4)$ \\
\hline MIK 1.43 & & 92.5 & $0.58(0.03)$ & 90 & $26.1(2.1)$ \\
\hline MIK 1.00 & & $55.0^{*}$ & $0.62(0.14)$ & 100 & $27.8(3.9)$ \\
\hline MIK 0.71 & & $0.0^{*}$ & $-(-)$ & $0^{*}$ & $-(--)$ \\
\hline MIK 0.54 & & - & $-(--)$ & $0^{*}$ & $-(-\infty)$ \\
\hline MIK 0.45 & & $0.0^{*}$ & $-(-)$ & $0^{*}$ & $-(--)$ \\
\hline MIK 0.12 & & 80.0 & $0.60(0.05)$ & $0^{*}$ & $-(--)$ \\
\hline Control & Jan. 1991 & 100.0 & $0.54(0.06)$ & 100 & $25.0(2.4)$ \\
\hline MIK 1.43 & & $17.5^{*}$ & $0.49(-\infty)$ & 90 & $31.1(5.6)$ \\
\hline MIK 1.00 & & $20.0^{*}$ & $0.68(0.09)$ & 100 & $27.6(2.1)$ \\
\hline MIK 0.71 & & 67.5 & $0.55(0.03)$ & 100 & $27.6(2.8)$ \\
\hline MIK 0.54 & Jan. 19.91 & 70.0 & $0.58(0.06)$ & 100 & $26.6(2.6)$ \\
\hline MIK 0.45 & & 72.5 & $0.65(0.07)$ & 100 & $27.8(2.6)$ \\
\hline MIK 0.12 & & 70.0 & $0.62(0.01)$ & 100 & $25.8(1.4)^{*}$ \\
\hline Control & Mar. 1991 & 82.5 & $0.41(0.04)$ & 100 & $39.3(2.1)$ \\
\hline MIK 1.43 & & $15.0^{*}$ & $0.40(0.15)$ & 100 & $38.4(5.2)$ \\
\hline MIK 1.00 & & 60.0 & $0.37(0.08)$ & 100 & $36.6(2.2)$ \\
\hline MIK 0.71 & & 50.0 & $0.29(0.14)$ & 100 & $27.0(7.0)$ \\
\hline MIK 0.54 & & 57.5 & $0.56(0.13)$ & 100 & $29.5(5.5)$ \\
\hline MIK 0.45 & & 60.0 & $0.38(0.24)$ & 90 & $34.3(3.6)$ \\
\hline MIK 0.12 & & 72.5 & $0.37(0.06)$ & 100 & $34.0(8.7)$ \\
\hline Control & May 1991 & 97.5 & $0.56(0.08)$ & 100 & $43.0(2.8)$ \\
\hline MIK 1.43 & & 47.5 & $0.62(0.05)$ & 100 & $44.3(7.5)$ \\
\hline MIK 1.00 & & 65.0 & $0.55(0.05)$ & 90 & $41.3(4.2)$ \\
\hline MIK 0.71 & & 80.0 & $0.51(0.12)$ & 90 & $46.9(3.4)$ \\
\hline MIK 0.54 & & 70.0 & $0.54(0.08)$ & 100 & $46.3(9.4)$ \\
\hline MTK 0.45 & & 75.0 & $0.54(0.09)$ & 100 & $43.7(8.3)$ \\
\hline MIK 0.12 & & 82.5 & $0.47(0.09)$ & 100 & $44.9(7.1)$ \\
\hline Control & July 1991 & 95.0 & $0.58(0.01)$ & 100 & $36.7(5.4)$ \\
\hline MIK 1.43 & & 55.0 & $0.62(0.04)$ & 80 & $40.4(4.7)$ \\
\hline
\end{tabular}


Table B.2 (continued)

\begin{tabular}{|c|c|c|c|c|c|}
\hline \multirow[b]{2}{*}{ Sample $^{2}$} & \multirow[b]{2}{*}{ Date } & \multicolumn{2}{|c|}{ Fathead Minnow } & \multicolumn{2}{|c|}{ Ceriodaphnia dubia } \\
\hline & & $\begin{array}{c}\text { Mean survival } \\
\text { (\%) }\end{array}$ & $\begin{array}{l}\text { Mean (SD) growth } \\
\text { (mg/fish) }\end{array}$ & $\begin{array}{l}\text { Survival } \\
(\%)\end{array}$ & $\begin{array}{c}\text { Mean (SD) offspring/surviving } \\
\text { female }\end{array}$ \\
\hline MIK 1.00 & & 92.5 & $0.57(0.02)$ & 80 & $32.0(3.7)$ \\
\hline MIK 0.71 & & 95.0 & $0.62(0.05)$ & 100 & $39.9(7.2)$ \\
\hline MIK 0.54 & & 92.5 & $0.59(0.03)$ & 90 & $37.6(12.7)$ \\
\hline MIK 0.45 & & 92.5 & $0.58(0.12)$ & 90 & $38.9(7.9)$ \\
\hline MIK 0.12 & & 97.5 & $0.63(0.09)$ & 90 & $33.3(5.2)$ \\
\hline Control & Sep. 1991 & 100.0 & $0.51(0.02)$ & 100 & $26.8(8.6)$ \\
\hline MIK 1.43 & & 97.5 & $0.60(0.06)$ & 80 & $20.0(2.9)$ \\
\hline MIK 1.00 & & - & $\cdots(-)$ & - & $-(--)$ \\
\hline MIK 0.71 & & 92.5 & $0.65(0.02)$ & 80 & $17.5(2.4)$ \\
\hline MIK 0.54 & & 95.0 & $0.56(0.03)$ & 100 & $19.3(9.6)$ \\
\hline MIK 0.45 & & 97.5 & $0.60(0.03)$ & 100 & $24.8(2.6)$ \\
\hline MTK 0.12 & & 87.5 & $0.55(0.01)$ & 100 & $14.5(7.4)$ \\
\hline Control & Nov. 1991 & 87.5 & $0.39(0.13)$ & 100 & $27.9(4.7)$ \\
\hline MIK 1.43 & & - & $-(-)$ & 90 & $11.0(5.7)^{*}$ \\
\hline MIK 1.00 & & - & $-(--)$ & 90 & $11.1(3.9)^{*}$ \\
\hline MIK 0.71 & & 80.0 & $0.54(0.15)$ & 100 & $17.5(3.4)$ \\
\hline MIK 0.54 & & 70.0 & $0.51(0.03)$ & 100 & $17.7(3.7)$ \\
\hline MIK 0.45 & & 80.0 & $0.51(0.07)$ & 90 & $15.8(2.0)$ \\
\hline MTK 0.12 & & 62.5 & $0.51(0.06)$ & 100 & $18.3(4.2)$ \\
\hline Control & Jan. 1992 & 80.0 & $0.59(0.05)$ & 90 & 31.1 (3.1) \\
\hline MIK 1.43 & & 75.0 & $0.55(0.05)$ & 100 & $30.3(4.9)$ \\
\hline MIK 1.00 & & 57.5 & $0.61(0.03)$ & 100 & $31.5(5.2)$ \\
\hline MIK 0.71 & & 92.5 & $0.58(0.07)$ & 100 & $25.7(4.4)^{*}$ \\
\hline MIK 0.54 & & 72.5 & $0.58(0.08)$ & 100 & $24.3(8.9)^{*}$ \\
\hline MIK 0.45 & & 80.0 & $0.58(0.09)$ & 100 & $28.3(3.1)$ \\
\hline MIK 0.12 & & 72.5 & $0.58(0.11)$ & 100 & $27.0(4.6)$ \\
\hline Control & Mar. 1992 & 55.0 & $0.62(0.04)$ & 80 & $27.4(5.9)$ \\
\hline MIK 1.43 & & 37.5 & $0.59(0.03)$ & 100 & $31.7(2.7)$ \\
\hline MIK 1.00 & & 62.5 & $0.65(0.13)$ & 100 & $31.1(5.2)$ \\
\hline MIK 0.71 & & 67.5 & $0.58(0.05)$ & 100 & $26.2(7.4)$ \\
\hline MIK 0.54 & & 65.0 & $0.50(0.04)$ & 100 & $27.3(3.8)$ \\
\hline MIK 0.45 & & 77.5 & $0.59(0.08)$ & 100 & $31.4(4.7)$ \\
\hline MIK 0.12 & & 72.5 & $0.60(0.17)$ & 90 & $31.0(4.0)$ \\
\hline Control & May 1992 & 100.0 & $0.57(0.03)$ & 80 & $32.0(2.7)$ \\
\hline
\end{tabular}


Table B.2 (continued)

\begin{tabular}{|c|c|c|c|c|c|}
\hline \multirow[b]{2}{*}{ Sample ${ }^{\mathrm{a}}$} & \multirow[b]{2}{*}{ Date } & \multicolumn{2}{|c|}{ Fathead Minnow } & \multicolumn{2}{|c|}{ Ceriodaphnia dubia } \\
\hline & & $\begin{array}{c}\text { Mean survival } \\
\text { (\%) }\end{array}$ & $\begin{array}{c}\text { Mean (SD) growth } \\
\text { (mg/fish) }\end{array}$ & $\begin{array}{l}\text { Survival } \\
(\%)\end{array}$ & $\begin{array}{c}\text { Mean (SD) offspring/surviving } \\
\text { female }\end{array}$ \\
\hline MIK 1.43 & & 55.0 & $0.79(0.06)$ & 100 & $29.0(2.3)$ \\
\hline MIK 1.00 & & 60.0 & $0.79(0.04)$ & 90 & $32.7(6.9)$ \\
\hline MIK 0.71 & & 87.5 & $0.68(0.03)$ & 80 & $15.9(5.7)^{*}$ \\
\hline MIK 0.54 & & 75.0 & $0.73(0.12)$ & 90 & $15.2(4.5)^{*}$ \\
\hline MIK 0.45 & & 87.5 & $0.69(0.01)$ & 90 & $18.8(8.1)^{*}$ \\
\hline MIK 0.12 & & 82.5 & $0.62(0.08)$ & 100 & $19.9(8.4)^{*}$ \\
\hline Control & July 1992 & 95.0 & $0.40(0.03)$ & 100 & $18.7(5.6)$ \\
\hline MIK 1.43 & & 82.5 & $0.41(0.06)$ & 90 & $23.1(3.6)$ \\
\hline MIK 1.00 & & 95.0 & $0.36(0.04)$ & 90 & $23.1(4.8)$ \\
\hline MIK 0.71 & & 90.0 & $0.39(0.03)$ & 100 & $14.4(4.6)^{*}$ \\
\hline MIK 0.54 & & 92.5 & $0.38(0.06)$ & 100 & $18.7(4.6)$ \\
\hline MIK 0.45 & & 92.5 & $0.45(0.04)$ & 100 & $21.7(3.5)$ \\
\hline MIK 0.12 & & 100.0 & $0.45(0.04)$ & 100 & $17.2(4.1)^{*}$ \\
\hline Control & Sep. 1992 & 100.0 & $0.48(0.02)$ & 100 & $28.0(4.9)$ \\
\hline MIK 1.43 & & 97.5 & $0.57(0.03)$ & 100 & $30.6(2.9)$ \\
\hline MIK 1.00 & & 95.0 & $0.60(0.03)$ & 100 & $27.7(8.3)$ \\
\hline MIK 0.71 & & 97.5 & $0.64(0.05)$ & $0^{*}$ & $\ldots(-)$ \\
\hline MIK 0.54 & & 100.0 & $0.57(0.02)$ & $50^{*}$ & $11.0(3.9)^{*}$ \\
\hline MIK 0.45 & & 97.5 & $0.52(0.06)$ & 100 & $23.8(5.0)$ \\
\hline MIK 0.12 & & 95.0 & $0.49(0.07)$ & 100 & $28.5(7.3)$ \\
\hline Control & Nov. 1992 & 92.5 & $0.64(0.03)$ & 100 & $33.8(3.5)$ \\
\hline MIK 1.43 & & 82.5 & $0.66(0.09)$ & 100 & $31.2(5.4)$ \\
\hline MIK 1.00 & & 85.0 & $0.65(0.01)$ & 100 & $30.8(5.7)$ \\
\hline MIK 0.71 & & 72.5 & $0.65(0.05)$ & $60^{*}$ & $7.5(4.3)^{*}$ \\
\hline MIK 0.54 & & 90.0 & $0.56(0.02)$ & 100 & $13.1(6.9)^{*}$ \\
\hline MIK 0.45 & & 95.0 & $0.54(0.02)$ & 100 & $12.3(8.0)^{*}$ \\
\hline MIK 0.12 & & 87.5 & $0.59(0.07)$ & 100 & $26.8(8.1)$ \\
\hline Control & Feb. 1993 & 97.5 & $0.61(0.11)$ & 100 & $22.2(5.1)$ \\
\hline MIK 1.43 & & 90.0 & $0.60(0.04)$ & 100 & $21.4(4.8)$ \\
\hline MIK 1.00 & & 97.5 & $0.60(0.04)$ & 90 & $21.7(3.3)$ \\
\hline MIK 0.71 & & 87.5 & $0.62(0.06)$ & 100 & $21.2(6.9)$ \\
\hline MIK 0.54 & & 97.5 & $0.58(0.03)$ & 100 & $18.8(3.4)$ \\
\hline MIK 0.45 & & 97.5 & $0.62(0.03)$ & 100 & $20.9(3.9)$ \\
\hline MIK 0.12 & & 97.5 & $0.60(0.03)$ & 100 & $21.2(4.7)$ \\
\hline
\end{tabular}


Table B.2 (continued)

\begin{tabular}{|c|c|c|c|c|c|}
\hline \multirow[b]{2}{*}{ Sample ${ }^{a}$} & \multirow[b]{2}{*}{ Date } & \multicolumn{2}{|c|}{ Fathead Minnow } & \multicolumn{2}{|c|}{ Ceriodaphnia dubia } \\
\hline & & $\begin{array}{c}\text { Mean survival } \\
\text { (\%) }\end{array}$ & $\begin{array}{l}\text { Mean (SD) growth } \\
\text { (mg/fish) }\end{array}$ & $\begin{array}{l}\text { Survival } \\
\text { (\%) }\end{array}$ & $\begin{array}{l}\text { Mean (SD) offspring/surviving } \\
\text { female }\end{array}$ \\
\hline Control & Apr. 1993 & 100.0 & $0.42(0.06)$ & 90 & $39.6(11.6)$ \\
\hline MIX 1.43 & & 54.5 & $0.63(0.07)$ & 80 & $31.1(4.6)$ \\
\hline MIK 0.78 & & 75.2 & $0.52(0.09)$ & 100 & $34.4(13.7)$ \\
\hline MIK 0.71 & & 93.8 & $0.56(0.07)$ & $20^{*}$ & $34.0(2.8)$ \\
\hline MIK 0.54 & & 90.6 & $0.51(0.05)$ & 60 & $33.5(7.0)$ \\
\hline MIK 0.45 & & 90.6 & $0.53(0.05)$ & 60 & $33.3(7.3)$ \\
\hline MIK 0.12 & & 92.5 & $0.50(0.06)$ & 90 & $27.6(12.6)$ \\
\hline Control & Apr. 1993 & 100.0 & $0.42(0.06)$ & 90 & $24.6(10.2)$ \\
\hline PCK 18.2 & & 85.0 & $0.38(0.03)$ & 100 & $26.3(7.5)$ \\
\hline PCK 8.2 & & 80.0 & $0.43(0.04)$ & 100 & $27.7(6.7)$ \\
\hline PCK 6.9 & & 90.0 & $0.39(0.02)$ & 90 & $27.9(10.7)$ \\
\hline PCK 4.7 & Apr. 1993 & 97.5 & $0.41(0.04)$ & 80 & $24.5(9.4)$ \\
\hline PCK 1.6 & & 100.0 & $0.40(0.03)$ & 100 & $26.8(4.7)$ \\
\hline CRK 15.0 & & 100.0 & $0.38(0.03)$ & 100 & $30.1(3.3)$ \\
\hline Control & July 1993 & 92.5 & $0.25(0.08)$ & 100 & $23.2(5.4)$ \\
\hline MIK 1.43 & & 80.0 & $0.33(0.02)$ & 90 & $22.1(5.0)$ \\
\hline MaK 1.00 & & 75.0 & $0.32(0.13)$ & 90 & $27.7(3.2)$ \\
\hline MIK 0.71 & & 77.5 & $0.29(0.03)$ & 80 & $20.0(6.1)$ \\
\hline MIK 0.54 & & 80.0 & $0.27(0.09)$ & 90 & $26.4(6.0)$ \\
\hline MIK 0.45 & & 85.0 & $0.31(0.11)$ & 100 & $29.8(3.3)$ \\
\hline MIK 0.12 & & 67.5 & $0.23(0.06)$ & 100 & $23.2(5.4)$ \\
\hline Control & July 1993 & 90.0 & $0.33(0.06)$ & 80 & $25.3(7.9)$ \\
\hline PCK 18.2 & & 80.0 & $0.32(0.09)$ & 100 & $30.8(6.4)$ \\
\hline PCK 8.2 & & 80.0 & $0.38(0.04)$ & 100 & $31.0(11.8)$ \\
\hline PCK 6.9 & & 65.0 & $0.35(0.08)$ & 80 & $33.2(5.3)$ \\
\hline PCK 4.7 & & 72.5 & $0.37(0.05)$ & 90 & $33.8(3.9)$ \\
\hline PCK 1.6 & & 67.5 & $0.42(0.10)$ & 100 & $31.7(6.1)$ \\
\hline CRK 15.0 & & 90.0 & $0.30(0.06)$ & 100 & $32.3(6.5)$ \\
\hline Control & Oct. 1993 & 87.5 & $0.39(0.07)$ & 100 & $28.5(3.9)$ \\
\hline MIK 1.43 & & $35.0^{*}$ & $0.47(0.09)$ & 100 & $31.7(6.4)$ \\
\hline MIK 0.78 & & 80.0 & $0.57(0.10)$ & 90 & $31.1(5.4)$ \\
\hline MKK 0.71 & & 82.5 & $0.43(0.03)$ & 100 & $23.3(4.1)^{*}$ \\
\hline MIK 0.54 & & 72.5 & $0.45(0.06)$ & 100 & $30.3(5.2)$ \\
\hline MIK 0.45 & & 65.0 & $0.50(0.07)$ & 90 & $30.9(6.2)$ \\
\hline
\end{tabular}


Table B.2 (continued)

\begin{tabular}{|c|c|c|c|c|c|}
\hline \multirow[b]{2}{*}{ Sample ${ }^{a}$} & \multirow[b]{2}{*}{ Date } & \multicolumn{2}{|c|}{ Fathead Minnow } & \multicolumn{2}{|c|}{ Ceriodaphnia dubia } \\
\hline & & $\begin{array}{l}\text { Mean survival } \\
\text { (\%) }\end{array}$ & $\begin{array}{l}\text { Mean (SD) growth } \\
\text { (mg/fish) }\end{array}$ & $\begin{array}{l}\text { Survival } \\
(\%)\end{array}$ & $\begin{array}{l}\text { Mean (SD) offspring/surviving } \\
\text { female }\end{array}$ \\
\hline MIK 0.12 & & 57.5 & $0.53(0.08)$ & 100 & $30.9(5.0)$ \\
\hline Control & Oct. 1993 & 87.5 & $0.39(0.07)$ & 100 & $29.4(1.7)$ \\
\hline PCK 18.2 & & 70.0 & $0.54(0.11)$ & 100 & $32.8(4.8)$ \\
\hline PCK 8.2 & & 65.0 & $0.42(0.09)$ & 100 & $35.3(6.2)$ \\
\hline PCK 6.9 & & 87.5 & $0.46(0.05)$ & 100 & $31.6(4.8)$ \\
\hline PCK 4.7 & & 62.5 & $0.51(0.10)$ & 100 & $33.0(3.3)$ \\
\hline PCK 1.6 & & 60.0 & $0.39(0.08)$ & 100 & $32.7(3.0)$ \\
\hline CRK 15.0 & & 82.5 & $0.51(0.09)$ & 100 & $31.2(4.2)$ \\
\hline Control & Jan. 1994 & 100.0 & $0.42(0.03)$ & 100 & $26.6(2.9)$ \\
\hline MIK 1.43 & & 72.5 & $0.47(0.02)$ & 100 & $21.7(4.7)$ \\
\hline MaK 0.78 & & 92.5 & $0.45(0.08)$ & 100 & $21.2(2.40$ \\
\hline MIK 0.71 & & 97.5 & $0.44(0.05)$ & 90 & $20.9(2.4)$ \\
\hline MIK 0.54 & & 85.0 & $0.49(0.04)$ & 100 & $21.0(3.7)$ \\
\hline MIK 0.45 & & 95.0 & $0.46(0.05)$ & 100 & $18.1(6.1)$ \\
\hline MIK 0.12 & & 95.0 & $0.44(0.04)$ & 90 & $20.0(2.6)$ \\
\hline Control & Jan. 1994 & 100.0 & $0.41(0.05)$ & 100 & $18.4(3.4)$ \\
\hline PCK 18.2 & & 82.5 & $0.45(0.04)$ & 90 & $12.0(4.7)$ \\
\hline PCK 8.2 & & 77.5 & $0.48(0.12)$ & 100 & $15.4(2.1)$ \\
\hline PCK 6.9 & & 75.0 & $0.55(0.09)$ & 90 & $13.3(3.8)$ \\
\hline PCK 4.7 & & 82.5 & $0.54(0.06)$ & 90 & $17.3(4.0)$ \\
\hline PCK 1.6 & & 75.0 & $0.56(0.06)$ & 100 & $18.6(3.6)$ \\
\hline CRK 15.0 & & 95.0 & $0.48(0.02)$ & 100 & $18.2(1.8)$ \\
\hline
\end{tabular}

${ }^{\mathrm{a}} \mathrm{MIK}=$ Mitchell Branch kilometer, $\mathrm{PCK}=$ Poplar Creek kilometer, $\mathrm{CRK}=$ Clinch River kilometer. 
APPENDIX C

RESULTS OF QUALITY ASSURANCE/QUALITY CONTROL ANALYSES OF FISH SAMPLES 


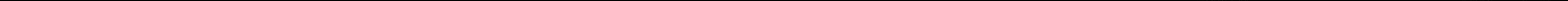


Table C.1. Mercury and other metals in fish from Mitchell Branch and nearby reaches of Poplar Creek and the Clinch River, 1991-1993

Measurements in micrograms per grams, wet weight unless otherwise indicated

\begin{tabular}{|c|c|c|c|c|c|c|c|c|c|c|c|c|c|c|c|c|}
\hline $\operatorname{Site}^{a}$ & Date & Spp. & Sex & Tag & $\begin{array}{l}\text { Wgt. } \\
\text { (g) }\end{array}$ & $\begin{array}{l}\text { Lgt. } \\
\text { (cm) }\end{array}$ & $\mathrm{Hg}$ & As & $\mathrm{Cd}$ & $\mathrm{Cr}$ & $\mathrm{Cu}$ & $\mathrm{Ni}$ & $\mathrm{Pb}$ & $\mathrm{Se}$ & $\mathrm{Tl}$ & $\mathrm{Zn}$ \\
\hline PCK 8.2 & $01 / 14 / 91$ & BLUGIL & $\mathbf{M}$ & 5605 & 56.0 & 14.0 & 0.47 & . & . & - & . & . & . & . & . & . \\
\hline PCK 8.2 & $01 / 14 / 91$ & BLUGIL & $\mathbf{M}$ & 5606 & 53.2 & 14.5 & 0.53 & . & . & . & . & . & . & . & . & . \\
\hline PCK 8.2. & $01 / 14 / 91$ & BLUGIL & $\mathbf{M}$ & 5607 & 46.5 & 14.1 & 0.28 & . & . & . & . & . & . & . & . & . \\
\hline PCK 8.2 & $01 / 14 / 91$ & BLUGIL & F & 5609 & 64.5 & 15.5 & 0.71 & . & . & . & . & . & . & . & . & . \\
\hline PCK 8.2 & $02 / 11 / 91$ & BLUGIL & $\mathbf{M}$ & 5644 & 69.5 & 17.4 & 0.62 & . & . & . & . & . & . & . & . & . \\
\hline PCK 8.2 & $02 / 11 / 91$ & BLUGIL & $\mathbf{M}$ & 5645 & 87.4 & 17.1 & 0.07 & . & . & . & . & . & . & . & . & . \\
\hline PCK 8.2 & $02 / 11 / 91$ & BLUGIL & $\mathbf{M}$ & 5646 & 64.2 & 15.5 & 0.30 & . & . & . & . & . & . & . & . & . \\
\hline PCK 8.2 & $02 / 11 / 91$ & BLUGIL & $\mathrm{F}$ & 5647 & 49.4 & 14.8 & 0.24 & . & . & . & . & . & . & . & . & . \\
\hline PCK 6.9 & $01 / 14 / 91$ & BLUGIL, & $\mathrm{F}$ & 5600 & 95.8 & 17.0 & 0.67 & . & . & . & . & . & . & . & . & . \\
\hline PCK 6.9 & $01 / 14 / 91$ & BLUGIL & $\mathrm{F}$ & 5601 & 52.1 & 14.5 & 0.57 & . & . & . & . & . & . & . & . & . \\
\hline PCK 6.9 & $01 / 14 / 91$ & BLUGIL & $\mathbf{M}$ & 5602 & 52.0 & 14.5 & 0.15 & . & . & . & . & . & . & . & . & . \\
\hline PCK 6.9 & $01 / 14 / 91$ & BLUGIL & $\mathbf{M}$ & 5603 & 78.0 & 16.1 & 0.32 & . & . & . & . & . & . & . & . & . \\
\hline PCK 6.9 & $01 / 14 / 91$ & BLUGIL & F & 5604 & 46.9 & 14.0 & 0.42 & . & . & . & . & . & . & . & . & . \\
\hline PCK 6.9 & $02 / 11 / 91$ & BLUGIL & $\mathbf{M}$ & 5640 & 63.8 & 15.6 & 0.24 & . & . & . & . & . & . & . & . & . \\
\hline PCK 6.9 & $02 / 11 / 91$ & BLUGIL & $\mathbf{M}$ & 5641 & 54.7 & 14.5 & 0.21 & . & . & . & . & . & . & . & . & . \\
\hline PCK 6.9 & $02 / 11 / 91$ & BLUGIL & $\mathbf{M}$ & 5643 & 51.9 & 15.0 & 0.40 & . & . & . & . & . & . & . & . & . \\
\hline MIK 0.2 & $01 / 18 / 91$ & REDBRE & $\mathrm{F}$ & 5610 & 41.5 & 14.0 & 0.56 & . & . & . & . & . & . & . & . & $\cdot$ \\
\hline MIK 0.2 & $01 / 18 / 91$ & REDBRE & $\mathbf{M}$ & 5612 & 30.4 & 12.2 & . & . & . & . & . & . & . & . & . & 5.9 \\
\hline MIK 0.2 & $01 / 18 / 91$ & REDBRE & $\mathrm{F}$ & 5614 & 26.9 & 11.7 & 0.27 & . & . & . & . & . & . & . & . & . \\
\hline MIK 0.2 & $01 / 18 / 91$ & REDBRE & $\mathbf{M}$ & 5617 & 22.4 & 10.5 & 0.20 & . & . & . & . & . & . & . & . & . \\
\hline MIK 0.2 & $01 / 18 / 91$ & REDBRE & $\mathrm{F}$ & 5618 & 18.3 & 10.2 & 0.18 & . & . & . & . & . & . & . & . & $\cdot$ \\
\hline MIK 0.2 & $01 / 18 / 91$ & REDBRE & M & 5386 & 93.1 & 17.6 & 0.29 & . & . & . & . & . & . & . & 0.02 & 5.1 \\
\hline MIK 0.2 & $01 / 18 / 91$ & REDBRE & $\mathrm{F}$ & 5387 & 71.0 & 16.0 & 0.45 & . & . & . & . & . & . & 0.73 & . & 6.0 \\
\hline MIK 0.2 & $01 / 18 / 91$ & REDBRE & F & 5388 & 63.6 & 15.9 & 0.35 & . & . & . & . & . & . & . & . & 6.0 \\
\hline MIK 0.2 & $01 / 18 / 91$ & REDBRE & F & 5389 & 22.9 & 11.1 & 0.23 & . & . & . & . & . & . & . & . & . \\
\hline
\end{tabular}


Table C.1 (continued)

\begin{tabular}{|c|c|c|c|c|c|c|c|c|c|c|c|c|c|c|c|c|}
\hline Site $^{a}$ & Date & Spp. ${ }^{b}$ & Sex & Tag & $\begin{array}{l}\text { Wgt. } \\
\text { (g) }\end{array}$ & $\begin{array}{l}\text { Lgt. } \\
\text { (cm) }\end{array}$ & $\mathrm{Hg}$ & As & $\mathrm{Cd}$ & $\mathrm{Cr}$ & $\mathrm{Cu}$ & $\mathrm{Ni}$ & $\mathrm{Pb}$ & $\mathrm{Se}$ & $\mathrm{Tl}$ & $\mathrm{Zn}$ \\
\hline CRK 15.0 & $02 / 12 / 91$ & BLUGIL & $M$ & 5620 & 70.9 & 16.4 & 0.22 & & . & . & . & . & . & . & . & . \\
\hline CRK 15.0 & $02 / 12 / 91$ & BLUGIL & $\mathbf{M}$ & 5621 & 84.5 & 17.1 & 0.42 & . & . & . & . & . & . & . & . & . \\
\hline CRK 15.0 & $02 / 12 / 91$ & BLUGIL & M & 5622 & 99.1 & 17.2 & 0.15 & . & . & . & . & . & . & . & . & . \\
\hline CRK 15.0 & $02 / 12 / 91$ & BLUGIL & $M$ & 5623 & 68.8 & 16.5 & 0.22 & . & . & . & . & . & . & . & . & . \\
\hline CRK 15.0 & $02 / 12 / 91$ & BLUGIL & $\mathbf{M}$ & 5624 & 96.0 & 17.8 & 0.11 & . & . & . & . & . & . & . & . & . \\
\hline CRK 15.0 & $02 / 12 / 91$ & BLUGIL & F & 5625 & 54.8 & 15.1 & 0.19 & . & . & . & . & . & . & . & . & . \\
\hline CRK 15.0 & $02 / 12 / 91$ & BLUGIL & $\mathbf{M}$ & 5626 & 67.0 & 16.5 & 0.15 & . & . & . & . & . & . & . & . & . \\
\hline CRK 15.0 & $02 / 12 / 91$ & BLUGIL & $\mathbf{M}$ & 5627 & 54.9 & 15.1 & 0.15 & . & . & . & . & . & . & . & . & . \\
\hline HINDSCR & $11 / 14 / 90$ & REDBRE & $\mathbf{M}$ & 5768 & 66.3 & 15.8 & 0.15 & . & . & . & . & . & . & . & . & . \\
\hline HINDSCR & $11 / 14 / 90$ & REDBRE & $\mathbf{M}$ & 5769 & 90.5 & 17.6 & 0.06 & . & . & . & . & . & . & . & . & . \\
\hline HINDSCR & $11 / 14 / 90$ & REDBRE & $\mathbf{F}$ & 5794 & 47.8 & 14.4 & 0.10 & . & . & . & . & . & . & . & . & . \\
\hline HINDSCR & $11 / 14 / 90$ & REDBRE & $\mathbf{M}$ & 5795 & 46.8 & 14.0 & 0.04 & . & . & . & . & . & . & . & . & 5.0 \\
\hline HINDSCR & $11 / 14 / 90$ & REDBRE & $\mathbf{M}$ & 5796 & 53.3 & 14.4 & 0.08 & . & . & . & . & . & . & . & . & . \\
\hline HINDSCR & $11 / 14 / 90$ & REDBRE & $\mathbf{M}$ & 5797 & 52.7 & 15.0 & 0.06 & . & . & . & . & . & . & . & . & . \\
\hline HINDSCR & $11 / 14 / 90$ & REDBRE & $\mathbf{F}$ & 5798 & 49.0 & 14.5 & 0.16 & . & . & . & . & . & . & . & . & . \\
\hline HINDSCR & $11 / 14 / 90$ & BLUGIL & $\mathbf{M}$ & 5760 & 87.9 & 17.1 & 0.08 & . & . & . & . & . & . & . & . & . \\
\hline HINDSCR & $11 / 14 / 90$ & BLUGIL & $\mathbf{M}$ & 5761 & 126.4 & 19.1 & 0.08 & . & . & . & . & . & . & . & . & . \\
\hline HINDSCR & $11 / 14 / 90$ & BLUGIL & $\mathbf{M}$ & 5762 & 144.2 & 19.4 & 0.09 & . & . & . & . & . & . & . & . & . \\
\hline HINDSCR & $11 / 14 / 90$ & BLUGIL & $F$ & 5763 & 69.1 & 15.7 & 0.10 & . & . & . & . & . & . & . & . & . \\
\hline HINDSCR & $11 / 14 / 90$ & BLUGIL & F & 5764 & 56.6 & 14.9 & 0.13 & . & . & . & . & . & . & . & . & . \\
\hline HINDSCR & $11 / 14 / 90$ & BLUGIL & $F$ & 5765 & 58.9 & 15.5 & 0.08 & . & . & . & . & . & . & . & . & . \\
\hline HINDSCR & $11 / 14 / 90$ & REDBRE & M & 5766 & 73.1 & 16.8 & 0.08 & . & . & . & . & . & . & . & . & . \\
\hline MIK 0.2 & $01 / 27 / 92$ & HYBRID & $\mathbf{M}$ & 3270 & 110.9 & 18.8 & 0.19 & . & . & . & . & . & . & . & . & . \\
\hline MIK 0.2 & $01 / 27 / 92$ & REDBRE & $\mathbf{M}$ & 3271 & 46.6 & 14.5 & 0.28 & . & . & . & . & . & . & . & . & 5.8 \\
\hline MIK 0.2 & $01 / 27 / 92$ & REDBRE & $\mathbf{M}$ & 3272 & 61.5 & 15.2 & 0.21 & . & . & . & . & . & . & . & . & 5.2 \\
\hline MIK 0.2 & $01 / 27 / 92$ & REDBRE & $\mathbf{M}$ & 3273 & 63.3 & 17.1 & 0.48 & . & . & . & . & . & . & . & . & 5.7 \\
\hline MIK 0.2 & $01 / 27 / 92$ & REDBRE & M & 3274 & 19.6 & 10.5 & 0.21 & . & . & . & . & . & . & . & . & . \\
\hline MIK 0.2 & $01 / 27 / 92$ & REDBRE & $\mathbf{M}$ & 3275 & 16.6 & 10.2 & 0.22 & . & . & . & . & . & . & . & . & 6.1 \\
\hline MIK 0.2 & $01 / 27 / 92$ & REDBRE & $\mathbf{M}$ & 3276 & 21.1 & 11.3 & 0.21 & . & . & . & . & . & . & . & . & : \\
\hline MIK 0.2 & $01 / 27 / 92$ & REDBRE & $\mathbf{M}$ & 4078 & 21.8 & 11.0 & 0.20 & . & . & . & . & . & . & . & . & 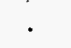 \\
\hline
\end{tabular}


Table C.1 (continued)

\begin{tabular}{|c|c|c|c|c|c|c|c|c|c|c|c|c|c|c|c|c|}
\hline Site $^{a}$ & Date & Spp. ${ }^{b}$ & Sex & Tag & $\begin{array}{l}\text { Wgt. } \\
\text { (g) }\end{array}$ & $\begin{array}{l}\text { Lgt. } \\
\text { (cm) }\end{array}$ & $\mathrm{Hg}$ & As & $\mathrm{Cd}$ & $\mathrm{Cr}$ & $\mathrm{Cu}$ & $\mathrm{Ni}$ & $\mathrm{Pb}$ & $\mathrm{Se}$ & $\mathrm{Tl}$ & $\mathrm{Zn}$ \\
\hline HINDSCR & $01 / 21 / 92$ & REDBRE & $\mathbf{F}$ & 3298 & 39.6 & 14.0 & 0.23 & . & . & . & . & . & . & . & - & . \\
\hline PCK 8.2 & $07 / 16 / 92$ & BLUGIL & $\mathbf{M}$ & 3990 & 97.3 & 16.3 & 0.41 & . & . & . & . & . & . & . & . & . \\
\hline PCK 8.2 & $07 / 16 / 92$ & BLUGIL & $\mathbf{M}$ & 3991 & 70.1 & 15.9 & 0.42 & . & . & . & . & . & . & . & . & . \\
\hline PCK 8.2 & $07 / 16 / 92$ & BLUGIL & $F$ & 3992 & 87.8 & 16.4 & 0.45 & . & . & . & . & . & . & . & . & . \\
\hline PCK 8.2 & $07 / 16 / 92$ & BLUGIL & $\mathbf{M}$ & 3993 & 91.0 & 16.8 & 0.44 & . & . & . & . & . & . & . & . & . \\
\hline PCK 8.2 & $07 / 16 / 92$ & BLUGIL & $\mathbf{M}$ & 3994 & 58.2 & 14.4 & 0.24 & . & . & . & . & . & . & . & . & . \\
\hline PCK 8.2 & $07 / 16 / 92$ & BLUGIL & $\mathbf{F}$ & 3995 & 101.0 & 17.2 & 0.49 & . & . & . & . & . & . & . & . & . \\
\hline PCK 8.2 & $07 / 16 / 92$ & BLUGIL & $\mathbf{M}$ & 3996 & 58.0 & 14.1 & 0.31 & . & . & . & . & . & . & . & . & . \\
\hline PCK 8.2 & $07 / 16 / 92$ & BLUGIL & $\mathbf{M}$ & 3997 & 50.0 & 13.8 & 0.24 & . & . & . & . & . & . & . & . & - \\
\hline PCK 6.9 & $07 / 16 / 92$ & BLUGIL & F & 3980 & 89.0 & 16.5 & 0.64 & . & . & . & . & . & . & . & . & . \\
\hline PCK 6.9 & $07 / 16 / 92$ & BLUGIL & $\mathbf{M}$ & 3981 & 86.6 & 16.2 & 0.27 & . & . & . & . & . & . & . & . & . \\
\hline PCK 6.9 & $07 / 16 / 92$ & BLUGIL & $\mathbf{M}$ & 3982 & 65.9 & 14.2 & 0.36 & . & . & . & . & . & . & . & . & . \\
\hline PCK 6.9 & $07 / 16 / 92$ & BLUGIL & $\mathbf{M}$ & 3983 & 80.9 & 15.5 & 0.42 & . & . & . & . & . & . & . & . & . \\
\hline PCK 6.9 & $07 / 16 / 92$ & BLUGIL & $\mathbf{M}$ & 3984 & 90.7 & 16.9 & 0.43 & . & . & . & . & . & . & . & . & . \\
\hline PCK 6.9 & $07 / 16 / 92$ & BLUGIL & $\dot{\mathbf{M}}$ & 3985 & 115.0 & 17.8 & 0.05 & . & . & . & . & . & . & . & . & - \\
\hline PCK 6.9 & $07 / 16 / 92$ & BLUGIL & $\mathbf{M}$ & 3987 & 75.7 & 15.4 & 0.33 & . & . & . & . & . & . & . & . & . \\
\hline PCK 6.9 & $07 / 16 / 92$ & BLUGIL & F & 3989 & 58.4 & 14.5 & 0.69 & . & . & . & . & . & . & . & . & . \\
\hline CRK 15.0 & $05 / 14 / 92$ & BLUGIL & $\mathbf{M}$ & 3552 & 84.3 & 16.5 & 0.09 & . & . & . & . & . & . & . & . & - \\
\hline CRK 15.0 & $05 / 14 / 92$ & BLUGIL & $\mathbf{M}$ & 3553 & 69.7 & 15.9 & 0.13 & . & . & . & . & . & . & . & . & . \\
\hline CRK 15.0 & $05 / 14 / 92$ & BLUGIL & $\mathbf{M}$ & 3554 & 89.5 & 16.7 & 0.12 & . & . & , & . & . & . & . & . & . \\
\hline CRK 15.0 & $05 / 14 / 92$ & BLUGIL & $\mathbf{F}$ & 3555 & 69.5 & 15.4 & 0.18 & . & . & . & . & . & . & . & . & . \\
\hline CRK 15.0 & $05 / 14 / 92$ & BLUGIL & $\mathbf{M}$ & 3556 & 74.0 & 15.8 & 0.10 & . & . & . & . & . & . & . & . & . \\
\hline CRK 15.0 & $05 / 14 / 92$ & BLUGIL & $\mathbf{M}$ & 3557 & 76.1 & 15.0 & 0.10 & . & . & . & . & . & . & . & . & . \\
\hline CRK 15.0 & $05 / 14 / 92$ & BLUGIL & $\mathbf{M}$ & 3558 & 68.7 & 15.5 & 0.13 & . & . & . & . & . & . & . & . & . \\
\hline CRK 15.0 & $05 / 14 / 92$ & BLUGIL & $F$ & 3559 & 54.3 & 14.9 & 0.71 & . & . & . & . & . & . & . & . & . \\
\hline MIK 0.2 & $03 / 11 / 93$ & REDBRE & $\mathbf{M}$ & 4330 & 72.6 & 16.0 & 0.42 & . & . & . & . & . & . & . & . & . \\
\hline MIK 0.2 & $03 / 11 / 93$ & REDBRE & M & 4331 & 64.1 & 15.4 & 0.28 & . & . & . & . & . & . & . & . & . \\
\hline MIK 0.2 & $03 / 11 / 93$ & REDBRE & $\mathbf{M}$ & 4332 & 64.1 & 15.4 & 0.29 & . & . & . & . & . & . & . & . & . \\
\hline MIK 0.2 & $03 / 11 / 93$ & REDBRE & $\mathbf{M}$ & 4333 & 65.2 & 15.5 & 0.28 & . & . & . & . & . & . & . & . & . \\
\hline MIK 0.2 & $03 / 11 / 93$ & REDBRE & $\mathbf{F}$ & 4334 & 55.5 & 14.5 & 0.46 & . & . & . & . & . & . & . & . & . \\
\hline
\end{tabular}


Table C.1 (continued)

\begin{tabular}{|c|c|c|c|c|c|c|c|c|c|c|c|c|c|c|c|c|}
\hline Site $^{a}$ & Date & Spp. ${ }^{b}$ & Sex & Tag & $\begin{array}{l}\text { Wgt. } \\
\text { (g) }\end{array}$ & $\begin{array}{l}\text { Lgt. } \\
\text { (cm) }\end{array}$ & $\mathrm{Hg}$ & As & $\mathrm{Cd}$ & $\mathrm{Cr}$ & $\mathrm{Cu}$ & $\mathrm{Ni}$ & $\mathrm{Pb}$ & $\mathrm{Se}$ & $\mathrm{Tl}$ & $\mathrm{Zn}$ \\
\hline MIK 0.2 & $03 / 11 / 93$ & REDBRE & $\mathbf{M}$ & 4335 & 65.3 & 14.8 & 0.16 & . & . & . & . & . & . & . & . & . \\
\hline MIK 0.2 & $03 / 11 / 93$ & REDBRE & $\mathbf{M}$ & 4336 & 63.0 & 15.1 & . & . & . & 0.11 & 0.21 & 0.07 & . & 0.36 & . & 5.3 \\
\hline MIK 0.2 & $03 / 11 / 93$ & REDBRE & $\mathbf{M}$ & 4337 & 49.4 & 14.5 & 0.37 & . & . & 0.11 & 0.26 & 0.07 & . & 0.55 & . & 4.6 \\
\hline MIK 0.2 & $03 / 11 / 93$ & REDBRE & $\mathbf{F}$ & 4338 & 61.5 & 14.3 & 0.37 & . & . & . & 0.26 & . & . & 0.35 & . & 5.3 \\
\hline MIK 0.2 & $03 / 11 / 93$ & REDBRE & $\mathbf{M}$ & 4379 & 47.1 & 13.3 & . & 0.05 & . & 0.05 & 0.23 & 0.06 & . & 0.39 & . & 5.7 \\
\hline $\mathrm{K} 1007 \mathrm{~B}^{c}$ & $03 / 11 / 93$ & BLUGIL & M & 4380 & 68.3 & 15.8 & 0.04 & . & . & 0.06 & 0.16 & . & . & 0.31 & . & 6.0 \\
\hline $\mathrm{K} 1007 \mathrm{~B}$ & $03 / 11 / 93$ & BLUGIL & M & 4381 & 50.5 & 14.9 & 0.07 & . & . & . & 0.17 & . & . & 0.28 & . & 6.3 \\
\hline K1007B & $03 / 11 / 93$ & BLUGIL & $\mathbf{M}$ & 4382 & 69.1 & 16.0 & 0.04 & . & . & . & 0.16 & . & . & 0.25 & . & 5.0 \\
\hline K1007B & $03 / 11 / 93$ & BLUGIL & $\mathbf{M}$ & 4383 & 55.2 & 15.1 & 0.04 & . & . & . & . & . & . & . & . & . \\
\hline K1007B & $03 / 11 / 93$ & BLUGIL & $\mathbf{M}$ & 4384 & 109.8 & 18.0 & 0.09 & . & . & . & 0.17 & . & . & 0.37 & . & 5.0 \\
\hline K1007B & $03 / 11 / 93$ & BLUGIL & $\mathbf{M}$ & 4385 & 75.7 & 166.4 & 0.05 & . & . & . & . & . & . & . & . & . \\
\hline K1007B & $03 / 11 / 93$ & BLUGIL & $\mathbf{M}$ & 4386 & 54.3 & 15.1 & 0.05 & . & . & . & . & . & . & . & . & . \\
\hline K1007B & $03 / 11 / 93$ & BLUGIL & $\mathbf{M}$ & 4387 & 62.2 & 15.6 & 0.03 & . & . & . & . & . & . & . & . & . \\
\hline $701 A^{c}$ & $03 / 25 / 93$ & BLUGIL & M & 4320 & 81.7 & 16.1 & 0.12 & 0.06 & 0.03 & 0.06 & 0.28 & . & . & 0.49 & . & 4.8 \\
\hline $701 \mathrm{~A}$ & $03 / 25 / 93$ & BLUGIL & $M$ & 4321 & 73.6 & 15.7 & 0.15 & 0.06 & . & 0.11 & 0.19 & . & . & 0.56 & . & 5.1 \\
\hline $701 \mathrm{~A}$ & $03 / 25 / 93$ & BLUGIL & M & 4322 & 119.8 & 17.9 & 0.14 & 0.05 & . & . & 0.13 & . & . & 0.65 & . & 5.7 \\
\hline $701 \mathrm{~A}$ & $03 / 25 / 93$ & BLUGIL & $\mathbf{M}$ & 4323 & 56.5 & 15.0 & 0.11 & 0.08 & . & . & 0.14 & . & . & 0.46 & . & 3.8 \\
\hline $701 \mathrm{~A}$ & $03 / 25 / 93$ & BLUGIL & M & 4324 & 67.5 & 15.3 & 0.09 & . & . & . & . & . & . & . & . & . \\
\hline $701 \mathrm{~A}$ & $03 / 25 / 93$ & BLUGIL & $\mathrm{M}$ & 4328 & 79.2 & 16.4 & 0.10 & . & . & . & . & . & . & . & . & . \\
\hline $701 \mathrm{~A}$ & $03 / 25 / 93$ & BLUGIL & M & 4329 & 85.2 & 16.5 & 0.14 & . & . & . & . & . & . & . & . & . \\
\hline $701 \mathrm{~A}$ & $03 / 25 / 93$ & BLUGIL & $\mathbf{M}$ & 4315 & 71.9 & 15.6 & 0.10 & . & . & . & . & . & . & . & . & . \\
\hline K1007B & $04 / 02 / 93$ & BLUGIL & $M$ & 4420 & 83.3 & 16.1 & 0.06 & . & . & . & 0.20 & . & . & 0.38 & . & 4.5 \\
\hline $\mathrm{K} 1007 \mathrm{~B}$ & $04 / 02 / 93$ & BLUGIL & M & 4421 & 77.8 & 17.0 & 0.09 & 0.05 & . & . & 0.15 & . & . & 0.34 & . & 7.1 \\
\hline K1007B & $04 / 02 / 93$ & BLUGIL & M & 4422 & 98.1 & 17.7 & 0.09 & 0.07 & . & . & 0.16 & . & . & 0.34 & . & 7.4 \\
\hline K1007B & $04 / 02 / 93$ & BLUGIL & $M$ & 4423 & 74.1 & 16.3 & 0.10 & . & . & . & 0.17 & . & . & 0.33 & . & 7.9 \\
\hline K1007B & $04 / 02 / 93$ & BLUGIL & $\mathrm{M}$ & 4424 & 61.9 & 14.9 & 0.08 & . & . & . & . & . & . & . & . & . \\
\hline K1007B & $04 / 02 / 93$ & BLUGIL & M & 4425 & 69.9 & 15.9 & 0.09 & . & . & . & . & . & . & . & . & . \\
\hline K1007B & $04 / 02 / 93$ & BLUGIL & $\mathrm{F}$ & 4426 & 58.0 & 15.1 & 0.08 & . & . & . & . & . & . & . & . & . \\
\hline K1007B & $04 / 02 / 93$ & BLUGIL & $\mathbf{M}$ & 4427 & 72.5 & 15.8 & 0.10 & . & . & . & . & . & . & . & . & . \\
\hline
\end{tabular}


Table C.1 (continued)

\begin{tabular}{|c|c|c|c|c|c|c|c|c|c|c|c|c|c|c|c|c|}
\hline Site $^{a}$ & Date & Spp..$^{b}$ & Sex & Tag & $\begin{array}{l}\text { Wgt. } \\
\text { (g) }\end{array}$ & $\begin{array}{l}\text { Lgt. } \\
\text { (cm) }\end{array}$ & $\mathrm{Hg}$ & As & $\mathrm{Cd}$ & $\mathrm{Cr}$ & $\mathrm{Cu}$ & $\mathrm{Ni}$ & $\mathrm{Pb}$ & $\mathrm{Se}$ & $\mathrm{Tl}$ & $\mathrm{Zn}$ \\
\hline PCK 6.9 & $03 / 09 / 93$ & BLUGIL & $\mathbf{M}$ & 4301 & 104.3 & 17.4 & 0.29 & . & . & . & . & . & . & . & . & . \\
\hline PCK 6.9 & $03 / 09 / 93$ & BLUGIL & $\mathbf{M}$ & 4302 & 103.7 & 16.8 & 0.47 & . & . & . & . & . & . & . & . & . \\
\hline PCK 6.9 & $03 / 09 / 93$ & BLUGIL & $\mathbf{F}$ & 4303 & 79.2 & 16.3 & 0.30 & . & . & . & . & . & . & . & . & . \\
\hline PCK 6.9 & $03 / 09 / 93$ & BLUGIL & $\mathbf{F}$ & 4304 & 89.1 & 16.8 & 0.38 & . & . & . & . & . & . & . & . & . \\
\hline PCK 6.9 & $03 / 09 / 93$ & BLUGIL & $\mathbf{M}$ & 4305 & 58.3 & 15.0 & 0.34 & . & . & . & . & . & . & . & . & . \\
\hline PCK 6.9 & $03 / 09 / 93$ & BLUGIL & $\mathbf{M}$ & 4306 & 96.9 & 16.7 & 0.32 & . & . & . & . & . & . & . & . & . \\
\hline PCK 6.9 & $03 / 09 / 93$ & BLUGIL & $\mathbf{M}$ & 4307 & 82.8 & 16.7 & 0.48 & . & . & . & . & . & . & . & . & . \\
\hline PCK 6.9 & $03 / 09 / 93$ & BLUGIL & $\mathbf{M}$ & 4308 & 53.1 & 14.4 & 0.30 & . & . & . & . & . & . & . & . & . \\
\hline PCK 1.6 & $03 / 09 / 93$ & BLUGIL & $\mathbf{M}$ & 4358 & 113.8 & 18.1 & 0.08 & 0.09 & . & 0.13 & 0.18 & . & . & 0.40 & . & 6.9 \\
\hline PCK 1.6 & $03 / 09 / 93$ & BLUGIL & $\mathbf{M}$ & 4359 & 85.8 & 16.7 & 0.07 & 0.07 & . & 0.05 & 0.19 & 0.08 & . & 0.49 & . & 3.9 \\
\hline PCK 1.6 & 03/09/93 & BLUGIL & $\mathbf{M}$ & 4360 & 71.4 & 15.7 & 0.44 & . & . & . & 0.19 & . . & . & 0.38 & . & 4.2 \\
\hline PCK 1.6 & $03 / 09 / 93$ & BLUGIL & $\mathbf{M}$ & 4361 & 70.3 & 15.5 & 0.44 & 0.08 & . & . & 0.22 & . & . & 0.52 & . & 5.0 \\
\hline PCK 1.6 & $03 / 09 / 93$ & BLUGIL. & $\mathbf{M}$ & 4362 & 66.1 & 15.2 & 0.19 & . & . & . & . & . & . & . & . & . \\
\hline PCK 1.6 & $03 / 09 / 93$ & BLUGIL & $\mathbf{M}$ & 4363 & 107.8 & 17.0 & 0.33 & . & . & . & . & . & . & . & . & . \\
\hline PCK 1.6 & $03 / 09 / 93$ & BLUGIL & $\mathbf{M}$ & 4364 & 97.8 & 17.0 & 0.19 & . & . & . & . & . & . & . & . & . \\
\hline PCK 1.6 & $03 / 09 / 93$ & BLUGIL & $\mathbf{F}$ & 4369 & 54.5 & 14.8 & 0.29 & . & . & . & . & . & . & . & . & . \\
\hline PCK 18.2 & $03 / 29 / 93$ & BLUGIL & $\mathbf{M}$ & 4480 & 121.3 & 17.6 & 0.04 & . & . & . & 0.15 & . & . & 0.38 & . & 4.8 \\
\hline PCK 18.2 & $03 / 29 / 93$ & BLUGIL & $\mathbf{M}$ & 4481 & 109.6 & 16.6 & 0.05 & . & . & . & 0.23 & . & . & 0.44 & . & 5.4 \\
\hline PCK 18.2 & $03 / 29 / 93$ & BLUGIL & $\mathbf{M}$ & 4482 & 92.1 & 17.0 & 0.12 & . & . & . & 0.11 & . & . & 0.30 & . & 6.7 \\
\hline PCK 18.2 & $03 / 29 / 93$ & BLUGIL & $\mathbf{M}$ & 4483 & 103.7 & 17.9 & 0.07 & . & . & . & 0.15 & . & . & 0.40 & . & 3.4 \\
\hline PCK 18.2 & $03 / 29 / 93$ & BLUGIL & $\mathbf{M}$ & 4484 & 93.9 & 16.0 & 0.05 & . & . & . & . & . & . & . & . & . \\
\hline PCK 18.2 & $03 / 29 / 93$ & BLUGIL & $\mathbf{F}$ & 4485 & 54.8 & 14.3 & 0.04 & . & . & . & . & . & . & . & . & . \\
\hline PCK 18.2 & $03 / 29 / 93$ & BLUGIL & $\mathbf{M}$ & 4487 & 48.8 & 13.4 & 0.05 & . & . & . & . & . & . & . & . & . \\
\hline PCK 18.2 & $03 / 29 / 93$ & BLUGIL & F & 4489 & 49.2 & 13.4 & 0.05 & . & . & . & . & . & . & . & . & . \\
\hline PCK 8.2 & $03 / 09 / 93$ & BLUGIL & $\mathbf{M}$ & 4370 & 89.4 & 15.9 & 0.32 & . & . & . & . & . & . & . & . & . \\
\hline PCK 8.2 & $03 / 09 / 93$ & BLUGIL & $\mathbf{M}$ & 4371 & 74.7 & 16.0 & 0.31 & . & . & . & . & . & . & . & . & . \\
\hline PCK 8.2 & $03 / 09 / 93$ & BLUGIL & $\mathbf{M}$ & 4372 & 71.9 & 15.7 & 0.33 & . & . & . & . & . & . & . & . & . \\
\hline PCK 8.2 & $03 / 09 / 93$ & BLUGIL & $\mathbf{M}$ & 4373 & 77.2 & 16.5 & 0.17 & . & . & . & . & . & . & . & . & . \\
\hline PCK 8.2 & $03 / 09 / 93$ & BLUGIL & $\mathbf{M}$ & 4374 & 154.0 & 20.1 & 0.39 & . & . & . & . & . & . & . & . & . \\
\hline PCK 8.2 & $03 / 09 / 93$ & BLUGIL & $\mathbf{M}$ & 4375 & 74.5 & 16.2 & 0.51 & . & . & . & & . & . & . & . & . \\
\hline PCK 8.2 & $03 / 09 / 93$ & BLUGIL & $\mathrm{F}$ & 4376 & 70.2 & 16.0 & 0.55 & . & . & . & . & . & . & . & . & . \\
\hline PCK 8.2 & $03 / 09 / 93$ & BLUGIL & . & 4377 & 60.1 & 14.5 & 0.15 & . & . & . & . & . & . & . & . & . \\
\hline
\end{tabular}


Table C.1 (continued)

\begin{tabular}{|c|c|c|c|c|c|c|c|c|c|c|c|c|c|c|c|c|}
\hline Site $^{a}$ & Date & Spp..$^{b}$ & Sex & Tag & $\begin{array}{l}\text { Wgt. } \\
\text { (g) }\end{array}$ & $\begin{array}{l}\text { Lgt. } \\
(\mathrm{cm})\end{array}$ & $\mathrm{Hg}$ & As & $\mathrm{Cd}$ & $\mathrm{Cr}$ & $\mathrm{Cu}$ & $\mathrm{Ni}$ & $\mathrm{Pb}$ & $\mathrm{Se}$ & $\mathrm{Tl}$ & $\mathrm{Zn}$ \\
\hline CRK 15.0 & $03 / 09 / 93$ & BLUGIL & $\mathbf{M}$ & 4350 & 82.8 & 16.0 & 0.23 & . & . & - & . & . & . & . & . & . \\
\hline CRK 15.0 & $03 / 09 / 93$ & BLUGIL & $\mathbf{M}$ & 4351 & 79.7 & 16.5 & 0.36 & . & , & . & . & . & . & . & . & . \\
\hline CRK 15.0 & $03 / 09 / 93$ & BLUGIL & $\mathbf{M}$ & 4352 & 102.4 & 17.6 & 0.16 & . & . & . & . & . & . & . & . & . \\
\hline CRK 15.0 & $03 / 09 / 93$ & BLUGIL & M & 4353 & 77.9 & 15.9 & 0.09 & . & . & . & . & . & . & . & . & . \\
\hline CRK 15.0 & $03 / 09 / 93$ & BLUGIL & $\mathbf{M}$ & 4354 & 62.3 & 15.5 & 0.17 & . & . & . & . & . & . & . & . & . \\
\hline CRK 15.0 & $03 / 09 / 93$ & BLUGIL & $\mathbf{M}$ & 4355 & 103.2 & 17.5 & 0.12 & . & . & . & . & . & . & . & . & . \\
\hline CRK 15.0 & $03 / 09 / 93$ & BLUGIL & $\mathbf{M}$ & 4356 & 55.2 & 14.9 & 0.12 & . & . & . & . & . & . & . & . & . \\
\hline CRK 15.0 & $03 / 09 / 93$ & BLUGIL & $\mathbf{M}$ & 4357 & 62.0 & 15.8 & 0.20 & . & . & . & . & . & . & . & . & . \\
\hline HINDSCR & $05 / 05 / 93$ & REDBRE & $\mathbf{M}$ & 4468 & 53.9 & 12.5 & 0.04 & . & . & . & . & . & . & . & . & . \\
\hline HINDSCR & $05 / 05 / 93$ & BLUGIL & $\mathbf{M}$ & 4472 & 53.1 & 14.0 & 0.09 & . & . & . & . & . & . & . & . & . \\
\hline HINDSCR & $05 / 05 / 93$ & BLUGIL & $\mathbf{M}$ & 4473 & 68.0 & 15.0 & 0.04 & . & . & . & . & . & . & . & . & . \\
\hline HINDSCR & $05 / 05 / 93$ & REDBRE & $\mathbf{M}$ & 4499 & 39.2 & 12.2 & 0.05 & . & . & . & . & . & . & . & . & . \\
\hline HINDSCR & $05 / 05 / 93$ & BLUGIL & $\mathbf{M}$ & 4540 & 77.9 & 15.7 & 0.10 & . & . & . & . & . & . & . & . & . \\
\hline HINDSCR & $05 / 05 / 93$ & BLUGIL & $\mathbf{M}$ & 4541 & 60.4 & 14.7 & 0.04 & . & . & . & . & . & . & . & . & . \\
\hline HINDSCR & $05 / 05 / 93$ & REDBRE & $\mathbf{M}$ & 4588 & 48.5 & 13.7 & 0.04 & . & . & . & . & . & . & . & . & . \\
\hline HINDSCR & $05 / 05 / 93$ & REDBRE & $\mathbf{F}$ & 4589 & 46.0 & 13.0 & 0.05 & . & . & . & . & . & . & . & . & . \\
\hline
\end{tabular}

${ }^{a} \mathrm{MIK}=$ Mitchell Branch kilometer, $\mathrm{PCK}=$ Poplar Creek kilometer, $\mathrm{CRK}=$ Clinch River kilometer, HINDSCR $=$ Hinds Creek

${ }^{b}$ Species: BLUGIL = Bluegill (Lepomis macrochirus) REDBRE $=$ redbreast sunfish (L. auritus).

cPonded tributaries of Poplar Creek. 
Table C.2. Concentrations of polychlorinated biphenyls (PCBs) in resident fish from Mitchell Branch and nearby reaches of Poplar Creek and the Clinch River, 1991-1993

Measurements given in micrograms per gram, wet weight unless otherwise indicated

\begin{tabular}{llllllllrrr}
\hline Site $^{a}$ & Date & Spp. & Sex & Tag & $\begin{array}{c}\text { Wgt. } \\
\text { (g) }\end{array}$ & $\begin{array}{c}\text { Lgt. } \\
\text { (cm) }\end{array}$ & $\sum$ PCB & $1254^{c}$ & $1260^{d}$ \\
\hline PCK 8.2 & $01 / 14 / 91$ & BLUGIL & M & 5605 & 56.0 & 14.0 & 0.10 & 0.02 & 0.08 \\
PCK 8.2 & $01 / 14 / 91$ & BLUGIL & M & 5606 & 53.2 & 14.5 & 0.10 & 0.04 & 0.06 \\
PCK 8.2 & $01 / 14 / 91$ & BLUGIL & M & 5607 & 46.5 & 14.1 & 0.10 & 0.03 & 0.07 \\
PCK 8.2 & $01 / 14 / 91$ & BLUGIL & F & 5609 & 64.5 & 15.5 & 0.02 & $<0.01$ & 0.02 \\
PCK 8.2 & $02 / 11 / 91$ & BLUGIL & M & 5644 & 69.5 & 17.4 & 0.01 & $<0.01$ & 0.01 \\
PCK 8.2 & $02 / 11 / 91$ & BLUGIL & M & 5645 & 87.4 & 17.1 & $<0.01$ & $<0.01$ & $<0.01$ \\
PCK 8.2 & $02 / 11 / 91$ & BLUGIL & M & 5646 & 64.2 & 15.5 & 0.02 & $<0.01$ & 0.02 \\
PCK 8.2 & $02 / 11 / 91$ & BLUGIL & F & 5647 & 49.4 & 14.8 & 0.02 & 0.01 & 0.02 \\
& & & & & & & & & \\
PCK 6.9 & $01 / 14 / 91$ & BLUGIL & F & 5600 & 95.8 & 17.0 & $<0.01$ & $<0.01$ & $<0.01$ \\
PCK 6.9 & $01 / 14 / 91$ & BLUGIL & F & 5601 & 52.1 & 14.5 & 0.07 & 0.02 & 0.05 \\
PCK 6.9 & $01 / 14 / 91$ & BLUGIL & M & 5602 & 52.0 & 14.5 & 0.01 & $<0.01$ & 0.01 \\
PCK 6.9 & $01 / 14 / 91$ & BLUGIL & M & 5603 & 78.0 & 16.1 & 0.05 & 0.02 & 0.03 \\
PCK 6.9 & $01 / 14 / 91$ & BLUGIL & F & 5604 & 46.9 & 14.0 & 0.07 & $<0.01$ & 0.07 \\
PCK 6.9 & $02 / 11 / 91$ & BLUGIL & M & 5640 & 63.8 & 15.6 & $<0.01$ & $<0.01$ & $<0.01$ \\
PCK 6.9 & $02 / 11 / 91$ & BLUGIL & M & 5641 & 54.7 & 14.5 & 0.04 & $<0.01$ & 0.04 \\
PCK 6.9 & $02 / 11 / 91$ & BLUGIL & M & 5643 & 51.9 & 15.0 & 0.08 & 0.02 & 0.06 \\
& & & & & & & & & \\
MIK 0.2 & $01 / 18 / 91$ & REDBRE & F & 5610 & 41.5 & 14.0 & 0.34 & 0.26 & 0.08 \\
MIK 0.2 & $01 / 18 / 91$ & REDBRE & M & 5612 & 30.4 & 12.2 & 0.52 & 0.42 & 0.10 \\
MIK 0.2 & $01 / 18 / 91$ & REDBRE & F & 5614 & 26.9 & 11.7 & 1.07 & 0.80 & 0.27 \\
MIK 0.2 & $01 / 18 / 91$ & REDBRE & M & 5617 & 22.4 & 10.5 & 0.79 & 0.62 & 0.17 \\
MIK 0.2 & $01 / 18 / 91$ & REDBRE & M & 5386 & 93.1 & 17.6 & 0.40 & 0.35 & 0.05 \\
MIK 0.2 & $01 / 18 / 91$ & REDBRE & F & 5387 & 71.0 & 16.0 & 0.03 & 0.03 & 0.01 \\
MIK 0.2 & $01 / 18 / 91$ & REDBRE & F & 5388 & 63.6 & 15.9 & 0.22 & 0.18 & 0.04 \\
MIK 0.2 & $01 / 18 / 91$ & REDBRE & F & 5389 & 22.9 & 11.1 & 1.28 & 1.04 & 0.24
\end{tabular}


Table C.2 (continued)

\begin{tabular}{|c|c|c|c|c|c|c|c|c|c|}
\hline Site $^{a}$ & Date & Spp. ${ }^{b}$ & Sex & Tag & $\begin{array}{l}\text { Wgt. } \\
\text { (g) }\end{array}$ & $\begin{array}{l}\text { Lgt. } \\
(\mathrm{cm})\end{array}$ & $\Sigma$ PCB & $1254^{c}$ & $1260^{d}$ \\
\hline HINDSCR & $11 / 14 / 90$ & REDBRE & M & 5767 & 74.2 & 17.0 & 0.07 & 0.07 & $<0.01$ \\
\hline HINDSCR & $11 / 14 / 90$ & REDBRE & $\mathbf{M}$ & 5769 & 90.5 & 17.6 & $<0.01$ & $<0.01$ & $<0.01$ \\
\hline HINDSCR & $11 / 14 / 90$ & REDBRE & $\mathbf{F}$ & 5794 & 47.8 & 14.4 & 0.01 & 0.01 & $<0.01$ \\
\hline HINDSCR & $11 / 14 / 90$ & REDBRE & $\mathbf{M}$ & 5796 & 53.3 & 14.4 & 0.02 & 0.02 & $<0.01$ \\
\hline HINDSCR & $11 / 14 / 90$ & REDBRE & $\mathbf{M}$ & 5797 & 52.7 & 15.0 & 0.01 & 0.01 & $<0.01$ \\
\hline HINDSCR & $11 / 14 / 90$ & REDBRE & $\mathbf{F}$ & 5798 & 49.0 & 14.5 & $<0.01$ & $<0.01$ & $<0.01$ \\
\hline HINDSCR & $11 / 14 / 90$ & BLUGIL & M & 5760 & 87.9 & 17.1 & 0.01 & 0.01 & $<0.01$ \\
\hline HINDSCR & $11 / 14 / 90$ & BLUGIL & $\mathbf{M}$ & 5761 & 126.4 & 19.1 & $<0.01$ & $<0.01$ & $<0.01$ \\
\hline HINDSCR & $11 / 14 / 90$ & BLUGIL & M & 5762 & 144.2 & 19.4 & $<0.01$ & $<0.01$ & $<0.01$ \\
\hline HINDSCR & $11 / 14 / 90$ & BLUGIL & $\mathbf{F}$ & 5763 & 69.1 & 15.7 & 0.01 & 0.01 & $<0.01$ \\
\hline HINDSCR & $11 / 14 / 90$ & BLUGIL & $\mathbf{F}$ & 5764 & 56.6 & 14.9 & $<0.01$ & $<0.01$ & $<0.01$ \\
\hline HINDSCR & $11 / 14 / 90$ & BLUGIL & $\mathbf{F}$ & 5765 & 58.9 & 15.5 & 0.05 & 0.05 & $<0.01$ \\
\hline MIK 0.2 & $01 / 27 / 92$ & HYBRID & M & 3270 & 110.9 & 18.8 & 1.74 & 1.21 & 0.53 \\
\hline MIK 0.2 & $01 / 27 / 92$ & REDBRE & $\mathbf{M}$ & 3271 & 46.6 & 14.5 & 1.02 & 0.21 & 0.81 \\
\hline MIK 0.2 & $01 / 27 / 92$ & REDBRE & M & 3272 & 61.5 & 15.2 & 0.40 & 0.23 & 0.17 \\
\hline MIK 0.2 & $01 / 27 / 92$ & REDBRE & $\mathbf{M}$ & 3273 & 63.3 & 17.1 & 3.05 & $<0.01$ & 3.05 \\
\hline MIK 0.2 & $01 / 27 / 92$ & BLUGIL & $\mathbf{M}$ & 3277 & 51.2 & 14.3 & 1.91 & 1.56 & 0.35 \\
\hline MIK 0.2 & $01 / 27 / 92$ & BLUGIL & $\mathbf{M}$ & 3278 & 27.4 & 11.6 & 0.74 & 0.42 & 0.32 \\
\hline MIK 0.2 & $01 / 27 / 92$ & BLUGIL & $\mathbf{M}$ & 3279 & 33.2 & 12.7 & 1.43 & 0.68 & 0.75 \\
\hline MIK 0.2 & $01 / 27 / 92$ & BLUGIL & $F$ & 4079 & 29.6 & 12.5 & 0.42 & 0.12 & 0.30 \\
\hline HINDS CR & $01 / 21 / 92$ & REDBRE & $\mathbf{M}$ & 3290 & 100.9 & 18.5 & $<0.01$ & $<0.01$ & $<0.01$ \\
\hline PCK 8.2 & $07 / 16 / 92$ & BLUGIL & $\mathbf{M}$ & 3990 & 97.3 & 16.3 & $<0.01$ & $<0.01$ & $<0.01$ \\
\hline PCK 8.2 & $07 / 16 / 92$ & BLUGIL & $\mathbf{M}$ & 3991 & 70.1 & 15.9 & 0.02 & $<0.01$ & 0.02 \\
\hline PCK 8.2 & $07 / 16 / 92$ & BLUGIL & $F$ & 3992 & 87.8 & 16.4 & 0.07 & 0.02 & 0.05 \\
\hline PCK 8.2 & $07 / 16 / 92$ & BLUGIL & $\mathbf{M}$ & 3993 & 91.0 & 16.8 & 0.03 & $<0.01$ & 0.03 \\
\hline PCK 8.2 & $07 / 16 / 92$ & BLUGIL & $\mathbf{M}$ & 3994 & 58.2 & 14.4 & 0.05 & 0.01 & 0.04 \\
\hline PCK 8.2 & $07 / 16 / 92$ & BLUGIL & $\mathbf{F}$ & 3995 & 101.0 & 17.2 & 0.03 & 0.01 & 0.02 \\
\hline PCK 8.2 & $07 / 16 / 92$ & BLUGIL & $\mathbf{M}$ & 3996 & 58.0 & 14.1 & 0.02 & $<0.01$ & 0.02 \\
\hline PCK 8.2 & $07 / 16 / 92$ & BLUGIL & M & 3997 & 50.0 & 13.8 & 0.03 & 0.02 & 0.01 \\
\hline
\end{tabular}


Table C.2 (continued)

\begin{tabular}{|c|c|c|c|c|c|c|c|c|c|}
\hline Site $^{\alpha}$ & Date & Spp. $^{b}$ & Sex & Tag & $\begin{array}{l}\text { Wgt. } \\
\text { (g) }\end{array}$ & $\begin{array}{l}\text { Lgt. } \\
\text { (cm) }\end{array}$ & $\sum \mathrm{PCB}$ & $1254^{c}$ & $1260^{d}$ \\
\hline PCK 6.9 & $07 / 16 / 92$ & BLUGIL & $\mathbf{F}$ & 3980 & 89.0 & 16.5 & 0.02 & $<0.01$ & 0.02 \\
\hline PCK 6.9 & $07 / 16 / 92$ & BLUGIL & $\mathbf{M}$ & 3981 & 86.6 & 16.2 & 0.02 & 0.01 & 0.01 \\
\hline PCK 6.9 & $07 / 16 / 92$ & BLUGIL & M & 3982 & 65.9 & 14.2 & 0.05 & 0.02 & 0.03 \\
\hline PCK 6.9 & $07 / 16 / 92$ & BLUGIL & $\mathbf{M}$ & 3983 & 80.9 & 15.5 & 0.08 & 0.01 & 0.07 \\
\hline PCK 6.9 & $07 / 16 / 92$ & BLUGIL & $\mathbf{M}$ & 3984 & 90.7 & 16.9 & 0.09 & 0.02 & 0.07 \\
\hline PCK 6.9 & $07 / 16 / 92$ & BLUGIL & M & 3985 & 115.0 & 17.8 & 0.07 & 0.04 & 0.03 \\
\hline PCK 6.9 & $07 / 16 / 92$ & BLUGIL & $\mathbf{M}$ & 3987 & 75.7 & 15.4 & 0.06 & $<0.01$ & 0.06 \\
\hline PCK 6.9 & $07 / 16 / 92$ & BLUGIL & $\mathrm{F}$ & 3989 & 58.4 & 14.5 & 0.06 & 0.06 & $<0.01$ \\
\hline MIK 0.2 & $03 / 11 / 93$ & REDBRE & M & 4330 & 72.6 & 16.0 & 0.91 & 0.70 & 0.21 \\
\hline MIK 0.2 & $03 / 11 / 93$ & REDBRE & $\mathbf{M}$ & 4331 & 64.1 & 15.4 & 1.25 & 0.63 & 0.62 \\
\hline MIK 0.2 & $03 / 11 / 93$ & REDBRE & $\mathbf{M}$ & 4332 & 64.1 & 15.4 & 0.49 & 0.32 & 0.17 \\
\hline MIK 0.2 & $03 / 11 / 93$ & REDBRE & $\mathbf{M}$ & 4333 & 65.2 & 15.5 & 0.77 & 0.60 & 0.17 \\
\hline MIK 0.2 & $03 / 11 / 93$ & REDBRE & $\mathrm{F}$ & 4334 & 55.5 & 14.5 & 0.10 & 0.06 & 0.04 \\
\hline MIK 0.2 & $03 / 11 / 93$ & REDBRE & M & 4335 & 65.3 & 14.8 & 1.36 & 0.95 & 0.41 \\
\hline MIK 0.2 & $03 / 11 / 93$ & REDBRE & $\mathbf{M}$ & 4337 & 49.4 & 14.5 & 0.66 & 0.11 & 0.55 \\
\hline MIK 0.2 & $03 / 11 / 93$ & REDBRE & $\mathbf{F}$ & 4338 & 61.5 & 14.3 & 0.57 & 0.33 & 0.24 \\
\hline $\mathrm{K}-1007 \mathrm{~B}^{e}$ & $03 / 11 / 93$ & BLUGIL & $\mathbf{M}$ & 4382 & 69.1 & 16.0 & 0.04 & $<0.01$ & 0.04 \\
\hline K-1007B & $03 / 11 / 93$ & BLUGIL & $\mathbf{M}$ & 4383 & 55.2 & 15.1 & 0.03 & 0.03 & $<0.01$ \\
\hline K-1007B & $03 / 11 / 93$ & BLUGIL & $\mathbf{M}$ & 4384 & 109.8 & 18.0 & 0.02 & 0.02 & $<0.01$ \\
\hline K-1007B & $03 / 11 / 93$ & BLUGIL & M & 4385 & 75.7 & 16.6 & 0.01 & 0.01 & $<0.01$ \\
\hline PCK 6.9 & $03 / 09 / 93$ & BLUGIL & $\mathbf{M}$ & 4301 & 104.3 & 17.4 & 0.81 & 0.50 & 0.31 \\
\hline PCK 6.9 & $03 / 09 / 93$ & BLUGIL & $\mathbf{M}$ & 4302 & 103.7 & 16.8 & 0.09 & 0.01 & 0.08 \\
\hline PCK 6.9 & $03 / 09 / 93$ & BLUGIL & $\mathbf{F}$ & 4303 & 79.2 & 16.3 & 0.07 & 0.03 & 0.04 \\
\hline PCK 6.9 & $03 / 09 / 93$ & BLUGIL & $\mathbf{F}$ & 4304 & 89.1 & 16.8 & 0.03 & $<0.01$ & 0.03 \\
\hline PCK 6.9 & $03 / 09 / 93$ & BLUGIL & $\mathbf{M}$ & 4305 & 58.3 & 15.0 & 0.04 & 0.02 & 0.02 \\
\hline PCK 6.9 & $03 / 09 / 93$ & BLUGIL & $\mathbf{M}$ & 4306 & 96.9 & 16.7 & 0.15 & $<0.01$ & 0.15 \\
\hline PCK 6.9 & $03 / 09 / 93$ & BLUGIL & $\mathbf{M}$ & 4307 & 82.8 & 16.7 & 0.10 & $<0.01$ & 0.10 \\
\hline PCK 6.9 & $03 / 09 / 93$ & BLUGIL & M & 4308 & 53.1 & 14.4 & 0.10 & $<0.01$ & 0.10 \\
\hline
\end{tabular}


Table C.2 (continued)

\begin{tabular}{|c|c|c|c|c|c|c|c|c|c|}
\hline $\mathrm{Site}^{a}$ & Date & Spp..$^{b}$ & Sex & Tag & $\begin{array}{l}\text { Wgt. } \\
\text { (g) }\end{array}$ & $\begin{array}{l}\text { Lgt. } \\
\text { (cm) }\end{array}$ & $\Sigma$ PCB & $1254^{c}$ & $1260^{d}$ \\
\hline PCK 1.6 & $03 / 09 / 93$ & BLUGIL & $\mathbf{M}$ & 4358 & 113.8 & 18.1 & 0.02 & 0.02 & $<0.01$ \\
\hline PCK 1.6 & $03 / 09 / 93$ & BLUGIL & $\mathbf{M}$ & 4359 & 85.8 & 16.7 & 0.22 & 0.09 & 0.13 \\
\hline PCK 1.6 & $03 / 09 / 93$ & BLUGIL & M & 4360 & 71.4 & 15.7 & 0.08 & 0.05 & 0.03 \\
\hline PCK 1.6 & $03 / 09 / 93$ & BLUGIL & M & 4361 & 70.3 & 15.5 & 0.08 & 0.06 & 0.02 \\
\hline PCK 1.6 & $03 / 09 / 93$ & BLUGIL & $\mathbf{M}$ & 4362 & 66.1 & 15.2 & 0.11 & 0.03 & 0.08 \\
\hline PCK 1.6 & $03 / 09 / 93$ & BLUGIL & $\mathbf{M}$ & 4363 & 107.8 & 17.0 & 0.11 & 0.04 & 0.07 \\
\hline PCK 1.6 & 03/09/93 & BLUGIL & $\mathbf{M}$ & 4364 & 97.8 & 17.0 & 0.15 & 0.01 & 0.14 \\
\hline PCK 1.6 & $03 / 09 / 93$ & BLUGIL & $\mathbf{F}$ & 4369 & 54.5 & 14.8 & 0.12 & 0.05 & 0.07 \\
\hline PCK 18.2 & $03 / 29 / 93$ & BLUGIL & M & 4480 & 121.3 & 17.6 & 0.10 & 0.02 & 0.08 \\
\hline PCK 18.2 & $03 / 29 / 93$ & BLUGIL & M & 4481 & 109.6 & 16.6 & 0.03 & 0.02 & 0.01 \\
\hline PCK 18.2 & $03 / 29 / 93$ & BLUGIL & M & 4482 & 92.1 & 17.0 & 0.06 & 0.06 & $<0.01$ \\
\hline PCK 18.2 & $03 / 29 / 93$ & BLUGIL & $\mathbf{M}$ & 4483 & 103.7 & 17.9 & 0.04 & 0.04 & $<0.01$ \\
\hline PCK 18.2 & $03 / 29 / 93$ & BLUGIL & M & 4484 & 93.9 & 16.0 & 0.03 & 0.01 & 0.02 \\
\hline PCK 18.2 & $03 / 29 / 93$ & BLUGIL & F & 4485 & 54.8 & 14.3 & 0.14 & 0.14 & $<0.01$ \\
\hline PCK 18.2 & $03 / 29 / 93$ & BLUGIL & $\mathbf{M}$ & 4487 & 48.8 & 13.4 & 0.13 & 0.13 & $<0.01$ \\
\hline PCK 18.2 & $03 / 29 / 93$ & BLUGIL & F & 4489 & 49.2 & 13.4 & 0.09 & $<0.01$ & 0.09 \\
\hline PCK 8.2 & $03 / 09 / 93$ & BLUGIL & M & 4370 & 89.4 & 15.9 & 0.02 & $<0.01$ & 0.02 \\
\hline PCK 8.2 & $03 / 09 / 93$ & BLUGIL & $\mathbf{M}$ & 4371 & 74.7 & 16.0 & 0.04 & $<0.01$ & 0.04 \\
\hline PCK 8.2 & $03 / 09 / 93$ & BLUGIL & M & 4372 & 71.9 & 15.7 & 0.05 & 0.02 & 0.03 \\
\hline PCK 8.2 & $03 / 09 / 93$ & BLUGIL & M & 4373 & 77.2 & 16.5 & 0.03 & $<0.01$ & 0.03 \\
\hline PCK 8.2 & $03 / 09 / 93$ & BLUGIL & M & 4374 & 154.0 & 20.1 & 0.04 & $<0.01$ & 0.04 \\
\hline PCK 8.2 & 03/09/93 & BLUGIL & M & 4375 & 74.5 & 16.2 & 0.04 & $<0.01$ & 0.04 \\
\hline PCK 8.2 & 03/09/93 & BLUGIL & $\mathbf{F}$ & 4376 & 70.2 & 16.0 & 0.02 & 0.01 & 0.01 \\
\hline PCK 8.2 & $03 / 09 / 93$ & BLUGIL & . & 4377 & 60.1 & 14.5 & $<0.01$ & $<0.01$ & $<0.01$ \\
\hline $701 A^{e}$ & $03 / 25 / 93$ & LMBASS & $\mathbf{F}$ & 4310 & 2604.0 & 53.8 & 0.74 & 0.13 & 0.61 \\
\hline $701 \mathrm{~A}$ & $03 / 25 / 93$ & LMBASS & M & 4448 & 1544.0 & 45.5 & 0.31 & 0.16 & 0.15 \\
\hline $701 \mathrm{~A}$ & $03 / 25 / 93$ & LMBASS & F & 4419 & 1413.0 & 43.7 & 0.14 & 0.06 & 0.08 \\
\hline $701 \mathrm{~A}$ & $03 / 25 / 93$ & LMBASS & $\mathbf{F}$ & 4418 & 2165.0 & 50.2 & 0.24 & 0.07 & 0.17 \\
\hline
\end{tabular}


Table C.2 (continued)

\begin{tabular}{llllllllrrr}
\hline \multicolumn{1}{c}{ Site $^{a}$} & Date & Spp. & Sex & Tag & $\begin{array}{c}\text { Wgt. } \\
(\mathrm{g})\end{array}$ & $\begin{array}{c}\text { Lgt. } \\
(\mathrm{cm})\end{array}$ & $\sum$ PCB & $1254^{c}$ & $1260^{d}$ \\
\hline K-1007B & $04 / 02 / 93$ & LMBASS & $\mathrm{M}$ & 4400 & 1846.0 & 50.5 & 8.76 & 4.91 & 3.76 \\
$\mathrm{~K}-1007 \mathrm{~B}$ & $04 / 02 / 93$ & LMBASS & $\mathrm{M}$ & 4401 & 2636.0 & 53.5 & 42.92 & 25.42 & 17.50 \\
$\mathrm{~K}-1007 \mathrm{~B}$ & $04 / 02 / 93$ & LMBASS & $\mathrm{F}$ & 4402 & 1141.0 & 41.5 & 8.17 & 5.38 & 2.79 \\
$\mathrm{~K}-1007 \mathrm{~B}$ & $04 / 02 / 93$ & LMBASS & $\mathrm{F}$ & 4403 & 1997.0 & 48.0 & 4.76 & 2.95 & 1.81 \\
& & & & & & & & & \\
K-1007B & $03 / 11 / 93$ & LMBASS & $\mathrm{F}$ & 4389 & 1460.0 & 45.0 & 0.13 & $<0.01$ & 0.13 \\
K-1007B & $03 / 11 / 93$ & LMBASS & $\mathrm{F}$ & 4388 & 1698.0 & 47.4 & 1.21 & 0.49 & 0.72 \\
& & & & & & & & & \\
HINDSCR & $05 / 05 / 93$ & REDBRE & $\mathrm{M}$ & 4469 & 54.5 & 13.6 & 0.05 & 0.05 & $<0.01$ \\
HINDSCR & $05 / 05 / 93$ & BLUGIL & $\mathrm{M}$ & 4473 & 68.0 & 15.0 & 0.09 & $<0.01$ & 0.09 \\
HINDSCR & $05 / 05 / 93$ & BLUGIL & $\mathrm{M}$ & 4540 & 77.9 & 15.7 & 0.21 & 0.21 & $<0.01$ \\
HINDSCR & $05 / 05 / 93$ & BLUGIL & $\mathrm{M}$ & 4541 & 60.4 & 14.7 & 0.07 & $<0.01$ & 0.07 \\
HINDSCR & $05 / 05 / 93$ & REDBRE & $\mathrm{M}$ & 4588 & 48.5 & 13.7 & 0.03 & 0.02 & 0.01 \\
HINDSCR & $05 / 05 / 93$ & REDBRE & $\mathrm{F}$ & 4589 & 46.0 & 13.0 & 0.11 & 0.11 & $<0.01$ \\
& & & & & & & & & \\
HINDSCR & $11 / 30 / 92$ & COCARP & $\mathrm{M}$ & 3769 & 2737.0 & 58.7 & 0.16 & 0.07 & 0.09 \\
HINDSCR & $11 / 30 / 92$ & COCARP & $\mathrm{F}$ & 4108 & 5171.0 & 71.0 & 0.05 & $<0.01$ & 0.05 \\
\hline
\end{tabular}

${ }^{a} \mathrm{MIK}=$ Mitchell Branch kilometer, $\mathrm{PCK}=$ Poplar Creek kilometer, $\mathrm{CRK}=$ Clinch River kilometer, HINDSCR $=$ Hinds Creek.

${ }^{b}$ BLUGIL - bluegill; REDBRE - redbreast sunfish; LMBASS = large-mouth bass.

${ }^{c} 1254$ - PCB-1254 (Arochlor 1254) in fish axial muscle; in micrograms per pram, wet weight.

${ }^{d} 1260$ - PCB-1260 (Arochlor 1260) in fish axial muscle, in micrograms per gram, wet weight.

${ }^{e}$ Ponded tributaries of Poplar Creek. 
Table C.3. Detection limits of organic compounds ( $\mu \mathrm{g} / \mathrm{g}$, wet wt)

\begin{tabular}{|c|c|}
\hline Compound & Detection limit \\
\hline \multicolumn{2}{|c|}{ CAPILLARY COLUMN GC/MS ${ }^{a}$} \\
\hline Phenol & $<0.1$ \\
\hline Bis(2-chloroethylether) & $<0.1$ \\
\hline 2-chlorophenol & $<0.1$ \\
\hline 1,3-Dichlorobenzene & $<0.1$ \\
\hline 1,4-Dichlorobenzene & $<0.1$ \\
\hline Benzyl Alcohol & $<0.1$ \\
\hline 1,2-Dichlorobenzene & $<0.1$ \\
\hline 2-Methylphenol & $<0.1$ \\
\hline Bis(2-Chlorodisopropyl) ether & $<0.1$ \\
\hline 4-Methylphenol & $<0.1$ \\
\hline $\mathrm{N}$-Nitroso-di- $\mathrm{N}$-propylamine & $<0.1$ \\
\hline Hexachloroethane & $<0.1$ \\
\hline Nitrobenzene & $<0.1$ \\
\hline Isophorone & $<0.1$ \\
\hline 2-Nitrophenol & $<0.1$ \\
\hline 2,4-Dimethylphenol & $<0.1$ \\
\hline Benzoic acid & $<0.1$ \\
\hline Bis(2-Chloroethoxy) methane & $<0.1$ \\
\hline 2,4-Dichlorophenol & $<0.1$ \\
\hline 1,2,4-Trichlorobenzene & $<0.1$ \\
\hline Naphthalene & $<0.1$ \\
\hline 4-Chloroaniline & $<0.1$ \\
\hline Hexachlorobutadiene & $<0.1$ \\
\hline 4-Chloro-3-methylphenol & $<0.1$ \\
\hline 2-Methylnaphthalene & $<0.1$ \\
\hline Hexachlorocyclopentadiene & $<0.1$ \\
\hline 2,4,6-Trichlorophenol & $<0.1$ \\
\hline $2,4,5$-Trichlorophenol & $<0.1$ \\
\hline 2-Chloronaphthalene & $<0.1$ \\
\hline 2-Nitroaniline & $<0.5$ \\
\hline Dimethylphthalate & $<0.1$ \\
\hline Acenaphthalene & $<0.1$ \\
\hline 3-Nitroaniline & $<0.5$ \\
\hline Acenaphthene & $<0.1$ \\
\hline 2,4-Dinitrophenol & $<0.5$ \\
\hline 4-Nitrophenol & $<0.5$ \\
\hline Dibenzofuran & $<0.1$ \\
\hline 2,4-Dinitrotoluene & $<0.1$ \\
\hline 2,6-Dinitrotoluene & $<0.1$ \\
\hline Diethylphthalate & $<0.1$ \\
\hline 4-Chlorophenol-phenylether & $<0.1$ \\
\hline Fluorene & $<0.1$ \\
\hline 4-Nitroaniline & $<0.5$ \\
\hline 4,6-Dinitro-2-methylphenol & $<0.5$ \\
\hline N-Nitrosodiphenolamine & $<0.1$ \\
\hline 4-bromophenol-phenylether & $<0.1$ \\
\hline Hexachlorobenzene & $<0.1$ \\
\hline Pentachorophenol & $<0.5$ \\
\hline Phenanthrene & $<0.1$ \\
\hline Anthracene & $<0.1$ \\
\hline Di- $N$-butylphthalate & $<0.1$ \\
\hline Fluoranthene & $<0.1$ \\
\hline Pyrene & $<0.1$ \\
\hline Butylbenzylphthalate & $<0.1$ \\
\hline
\end{tabular}


Table C.3 (continued)

\begin{tabular}{|c|c|}
\hline Compound & Detection limit \\
\hline 3,3-Dichlorobenzene & $<0.1$ \\
\hline Benz $[a]$ anthracene & $<0.1$ \\
\hline Bis(2-ethylhexyl)phthalate & $<0.1$ \\
\hline Chrysene & $<0.1$ \\
\hline Di- $N$-octylphthalate & $<0.1$ \\
\hline Benzo[b]fluoranthene & $<0.1$ \\
\hline Benzo $[k]$ fluoranthene & $<0.1$ \\
\hline Benzo $[a]$ pyrene & $<0.1$ \\
\hline Indeno $(1,2,3-c d)$ pyrene & $<0.1$ \\
\hline Dibenz $[a, h]$ anthracene & $<0.1$ \\
\hline Benzo $[g, h, i]$ perylene & $<0.1$ \\
\hline \multicolumn{2}{|c|}{ CAPILLARY COLUMN GC/ECD ${ }^{b}$} \\
\hline Alpha-bhe & $<0.001$ \\
\hline Beta-bhc & $<0.001$ \\
\hline Delta-bhc & $<0.001$ \\
\hline Gamma-bhc & $<0.001$ \\
\hline Heptachlor & $<0.001$ \\
\hline Aldrin & $<0.001$ \\
\hline Heptachlor epoxide & $<0.001$ \\
\hline Endosulfan I & $<0.001$ \\
\hline Dieldrin & $<0.002$ \\
\hline 4,4'-DDE & $<0.002$ \\
\hline Endrin & $<0.002$ \\
\hline Endosulfan II & $<0.002$ \\
\hline $4,4^{\prime}-\mathrm{DDD}$ & $<0.002$ \\
\hline Endosulfan Sulfate & $<0.002$ \\
\hline 4,4'-DDT & $<0.002$ \\
\hline Endrin ketone & $<0.002$ \\
\hline Methoxychlor & $<0.012$ \\
\hline Alpha chlordane & $<0.012$ \\
\hline Gamma chlordane & $<0.012$ \\
\hline Toxaphene & $<0.023$ \\
\hline
\end{tabular}

${ }^{a} \mathrm{GC} / \mathrm{MS}$ - gas chromatography/mass spectrometry.

${ }^{b} \mathrm{GC} / \mathrm{ECD}=$ gas chromatography/electron capture detector. 


\section{APPENDIX D}

CHECKLIST OF BENTHIC MACROINVERTEBRATE TAXA

FROM MITCHELL BRANCH, OCTOBER 1986

THROUGH APRIL 1993 


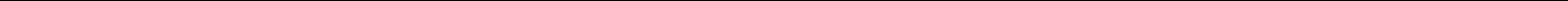


Table D.1. Checklist of benthic macroinvertebrates collected from Mitchell Branch, October 1986-April 1993

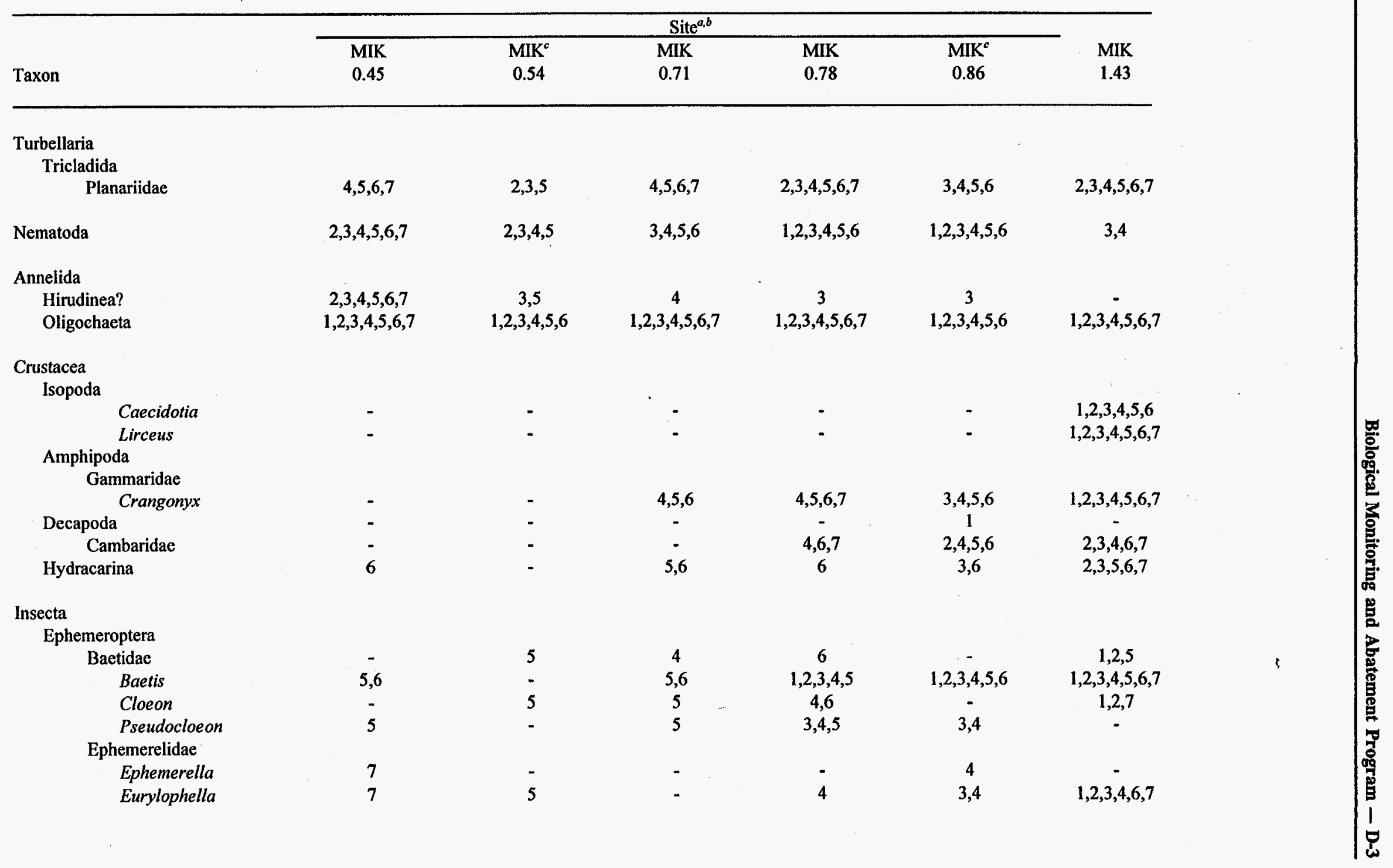


Odonata

Anisoptera

Aeshnidae

Boyeria vinosa

Cordulegastridae

Cordulegaster

Gomphidae

Gomphus

Stylogomphus albistylus

Libellulidae

$$
\text { Perithemis }
$$

Zygoptera

Calopterygidae Calopteryx

Site ${ }^{a, b}$

MIK

0.71

-
3
3
-
-
3,4
-
2
3,4
-
2,3

-
-
3
-
-
$3,4,5$
-
-
3,4
-
3,4

$1,4,5,6,7$

-

-

$1,2,3,4,5,6,7$

5

$2,3,4,5,7$

3

$2,3,4,5$
$1,3,4,5,7$

$1,2,4,5,6$

$3,4,5,6,7$

4

$4,5,6,7$ 
Table D.1 (continued)

\begin{tabular}{|c|c|c|c|c|c|c|}
\hline \multirow[b]{3}{*}{ Taxon } & \multicolumn{5}{|c|}{ Site ${ }^{a . b}$} & \multirow{3}{*}{$\begin{array}{c}\text { MIK } \\
1.43\end{array}$} \\
\hline & MIK & MIK $^{c}$ & MIK & MIK & $\mathrm{MIK}^{c}$ & \\
\hline & 0.45 & 0.54 & 0.71 & 0.78 & 0.86 & \\
\hline \multicolumn{7}{|l|}{ Odonata (continued) } \\
\hline Coenagrionidae & - & - & 2,7 & - & - & 7 \\
\hline Argia & $1,2,3,4,7$ & $2,3,4,5,6$ & $4,5,6,7$ & $2,5,6$ & 4,5 & 4 \\
\hline Enallagma & - & 2 & - & - & - & - \\
\hline Ischnura & 3 & 4 & - & 5 & - & - \\
\hline Plecoptera & - & - & - & - & 1 & $1,2,3,7$ \\
\hline Capniidae & - & - & - & - & - & 1 \\
\hline Allocapnia & 7 & - & $4,5,7$ & $3,4,6,7$ & $3,4,6$ & $2,3,4,5,6,7$ \\
\hline Capniidae/Leuctridae & - & - & - & - & 6 & 1 \\
\hline \multicolumn{7}{|l|}{ Plecoptera (continued) } \\
\hline Leuctridae & - & - & - & - & 2 & - \\
\hline Leuctra & $5,6,7$ & - & $5,6,7$ & $2,3,4,5$ & $3,4,5,6$ & $2,3,4,5,6,7$ \\
\hline \multicolumn{7}{|l|}{ Nemouridae } \\
\hline Amphinemura & - & - & $5,6,7$ & $2,3,4,5,6,7$ & $2,3,4,5,6$ & $1,2,3,4,5,6,7$ \\
\hline \multicolumn{7}{|l|}{ Peltoperlidae } \\
\hline Tallaperla & - & - & - & - & - & 7 \\
\hline Perlidae & - & - & - & - & - & $1,2,3,4,7$ \\
\hline Eccoptura xanthenes & - & - & 5 & - & $3,4,5,6$ & $4,5,6,7$ \\
\hline Perlesta & - & - & 7 & 5 & $2,3,5,6$ & $2,3,4,5,7$ \\
\hline Perlodidae & - & - & - & - & - & $2,4,5,6$ \\
\hline Clioperla clio & - & - & - & - & - & $3,4,5$ \\
\hline Isoperla & - & - & 5 & 2 & $2,5,6$ & 3,4 \\
\hline Perlidae/Perlodidae & - & - & 6 & - & $4,5,6$ & $2,3,4,5,7$ \\
\hline \multicolumn{7}{|l|}{ Taeniopterygidae } \\
\hline Taeniopteryx & 5 & - & - & - & - & - \\
\hline
\end{tabular}


Table D.1 (continued)

\begin{tabular}{|c|c|c|c|c|c|c|}
\hline \multirow[b]{3}{*}{ Taxon } & \multicolumn{5}{|c|}{ Site ${ }^{a, b}$} & \multirow{3}{*}{$\begin{array}{c}\text { MIK } \\
1.43\end{array}$} \\
\hline & MIK & $\mathrm{MIK}^{c}$ & MIK & MIK & $\mathrm{MIK}^{c}$ & \\
\hline & 0.45 & 0.54 & 0.71 & 0.78 & 0.86 & \\
\hline \multicolumn{7}{|l|}{ Megaloptera } \\
\hline \multicolumn{7}{|l|}{ Corydalidae } \\
\hline Nigronia fasciatus & - & - & - & - & - & $1,2,4,5,6$ \\
\hline \multicolumn{7}{|l|}{ Sialidae } \\
\hline Sialis & - & - & - & - & - & 2,7 \\
\hline Trichoptera & - & - & - & - & - & 1,2 \\
\hline \multicolumn{7}{|l|}{ Glossosomatidae } \\
\hline Agapetus & - & - & - & 4 & - & 4,7 \\
\hline Glossosoma & - & - & - & - & - & 7 \\
\hline \multicolumn{7}{|l|}{ Goeridae } \\
\hline Goera & - & - & - & - & - & 5 \\
\hline \multicolumn{7}{|l|}{ Hydropsychidae } \\
\hline Cheumatopsyche & $4,6,7$ & - & $5,6,7$ & $2,3,4,5,6,7$ & $2,3,4,5,6$ & 5 \\
\hline Diplectrona modesta & - & - & - & 4 & 4 & $1,3,4,5,6,7$ \\
\hline \multicolumn{7}{|l|}{ Hydroptilidae } \\
\hline Hydroptila & - & - & 5 & $4,5,6,7$ & - & - \\
\hline Ochrotrichia & - & - & - & 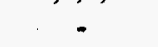 & 4 & - \\
\hline Ochrotrichia? & - & - & 7 & - & - & - \\
\hline Oxyethira & 4 & 4 & - & 4 & - & - \\
\hline \multicolumn{7}{|l|}{ Leptoceridae } \\
\hline Triaenodes & - & - & - & - & - & 1 \\
\hline \multicolumn{7}{|l|}{ Linmephilidae } \\
\hline Hydatophylax & - & - & - & - & - & 1 \\
\hline Neophylax & - & - & 5 & - & - & $3,5,7$ \\
\hline Pycnopsyche & - & - & - & - & - & $1,2,3,4,5,6,7$ \\
\hline Pycnopsyche? & - & - & - & - & - & $3,5,7$ \\
\hline \multicolumn{7}{|l|}{ Molannidae } \\
\hline Molanna & - & - & - & - & - & $3,4,6,7$ \\
\hline
\end{tabular}


Table D.1 (continued)

\begin{tabular}{|c|c|c|c|c|c|c|}
\hline \multirow[b]{3}{*}{ Taxon } & \multicolumn{5}{|c|}{ Site $^{a, b}$} & \multirow{3}{*}{$\begin{array}{c}\text { MIK } \\
1.43\end{array}$} \\
\hline & MIK & $\mathrm{MIK}^{c}$ & MIK & MIK & $\mathrm{MIK}^{\mathrm{c}}$ & \\
\hline & 0.45 & 0.54 & 0.71 & 0.78 & 0.86 & \\
\hline \multicolumn{7}{|l|}{ Trichoptera (continued) } \\
\hline \multicolumn{7}{|l|}{ Philopotamidae } \\
\hline $\begin{array}{c}\text { Chimarra } \\
\text { Polycentropodidae }\end{array}$ & - & - & - & 1,4 & 4,5 & $5,6,7$ \\
\hline $\begin{array}{l}\text { Polycentropus } \\
\text { Psychomyiidae }\end{array}$ & - & - & 5 & - & - & - \\
\hline $\begin{array}{l}\text { Lype diversa } \\
\text { Rhyacophilidae }\end{array}$ & - & - & - & - & - & $1,4,5,6$ \\
\hline Rhyacophila & - & - & - & - & - & 2 \\
\hline \multicolumn{7}{|l|}{ Coleoptera } \\
\hline \multicolumn{7}{|l|}{ Dryopidae } \\
\hline $\begin{array}{l}\text { Helichus } \\
\text { Dytiscidae }\end{array}$ & - & - & - & - & 4 & $1,4,5$ \\
\hline $\begin{array}{l}\text { Hydroporus } \\
\text { Elmidae }\end{array}$ & - & - & - & - & - & 3 \\
\hline Dubiraphia & 6 & 6 & 7 & 6 & - & $2,3,7$ \\
\hline Optioservus & 6 & - & 6,7 & $2,5,6,7$ & $3,4,5,6$ & $1,2,3,4,5,6,7$ \\
\hline Stenelmis & 4 & - & $3,4,6,7$ & $1,2,3,4,5,6,7$ & $1,2,3,4,5,6$ & $1,2,3,4,5,6,7$ \\
\hline Haliplidae & & & & & & \\
\hline Peltodytes & - & - & - & 3 & - & - \\
\hline Hydrophilidae & - & - & - & - & - & 2 \\
\hline $\begin{array}{l}\text { Tropisternus } \\
\text { Psephenidae }\end{array}$ & - & 4 & - & - & - & - \\
\hline $\begin{array}{l}\text { Psephenus herricki } \\
\text { Ptilodactylidae }\end{array}$ & 7 & - & 7 & - & - & - \\
\hline Ancytarsus bicolor & - & - & - & - & - & 1 \\
\hline Staphylinidae & - & - & 1 & 1 & - & - \\
\hline
\end{tabular}




\begin{tabular}{|c|c|c|c|c|c|c|}
\hline \multirow[b]{3}{*}{ Taxon } & \multicolumn{5}{|c|}{ Site Si,b $^{a}$} & \multirow{3}{*}{$\begin{array}{c}\mathrm{MIK} \\
1.43\end{array}$} \\
\hline & MIK & $\mathrm{MIK}^{c}$ & MIK & MIK & MIK $^{c}$ & \\
\hline & 0.45 & 0.54 & 0.71 & 0.78 & 0.86 & \\
\hline Diptera & - & - & - & $\quad-$ & 6 & 1 \\
\hline Ceratopogonidae & $2,3,4,5,6,7$ & $2,4,5,6$ & 2 & $1,3,4,6,7$ & $1,3,4,5,6$ & $1,2,3,4,5,6,7$ \\
\hline Atrichopogon & - & 4 & - & - & 3 & 3 \\
\hline Ceratopogonidae? & - & - & 5 & - & - & - \\
\hline Chironomidae & $2,3,4,5,6,7$ & $2,3,4,5,6$ & $3,4,5,6,7$ & $2,3,4,5,6,7$ & $2,3,4,5,6$ & $2,3,4,5,6,7$ \\
\hline Chironominae & 2 & 2 & - & - & - & 2 \\
\hline Chironomini & $1,2,3,4,5,6,7$ & $1,2,3,4,5,6$ & $3,4,5,6,7$ & $1,2,3,4,5,6,7$ & $1,3,4,5,6$ & $1,2,3,4,5,6,7$ \\
\hline Tanytarsini & $1,2,3,4,5,6,7$ & $1,2,3,4,5,6$ & $4,5,6,7$ & $2,3,4,5,6,7$ & $1,2,3,4,5,6$ & $1,2,3,4,5,6,7$ \\
\hline Diamesinae & - & - & - & 1 & 1 & - \\
\hline Orthocladiinae & $1,2,3,4,5,6,7$ & $1,2,3,4,5,6$ & $1,2,3,4,5,6,7$ & $1,2,3,4,5,6,7$ & $1,2,3,4,5,6$ & $1,2,3,4,5,6,7$ \\
\hline Podonominae & $=$ & - & - & - & - & 2,3 \\
\hline Tanypodinae & $1,2,3,4,5,6,7$ & $2,3,4,5,6$ & $2,4,5,6$ & $1,2,3,4,5,6,7$ & $1,2,3,4,5,6$ & $1,2,3,4,5,6,7$ \\
\hline \multicolumn{7}{|l|}{ Dixidae } \\
\hline Dixa & - & - & - & 5 & - & $1,2,3,4,5,6$ \\
\hline Dixella & - & - & - & - & - & 3,6 \\
\hline Dolicopodidae & - & - & 3 & - & - & 1,3 \\
\hline Dolicopodidae? & - & - & - & - & - & 2 \\
\hline \multicolumn{7}{|l|}{ Empididae } \\
\hline Hemerodromia & $2,3,6,7$ & $2,3,6$ & 6,7 & $1,4,6,7$ & $4,5,6$ & $3,4,5,6,7$ \\
\hline Empididae? & - & - & - & - & - & 1 \\
\hline Muscidae & - & - & 5 & - & - & 1 \\
\hline Psychodidae & - & - & - & - & - & 2 \\
\hline Pericoma & - & - & 5 & - & 3 & - \\
\hline Simuliidae & 1,2 & 1,4 & 4,6 & 1 & 1 & 1 \\
\hline Simulium & $2,3,4,5,7$ & $2,3,4,5,6$ & $2,3,4,5,6,7$ & $2,3,4,5,6,7$ & $2,3,4,5,6$ & $2,3,4,5,6$ \\
\hline Stratiomyidae & & & & & & \\
\hline Caloparyphus & - & - & - & - & 3 & - \\
\hline Stratiomys & 4 & - & - & - & - & - \\
\hline
\end{tabular}


Table D.1 (continued)

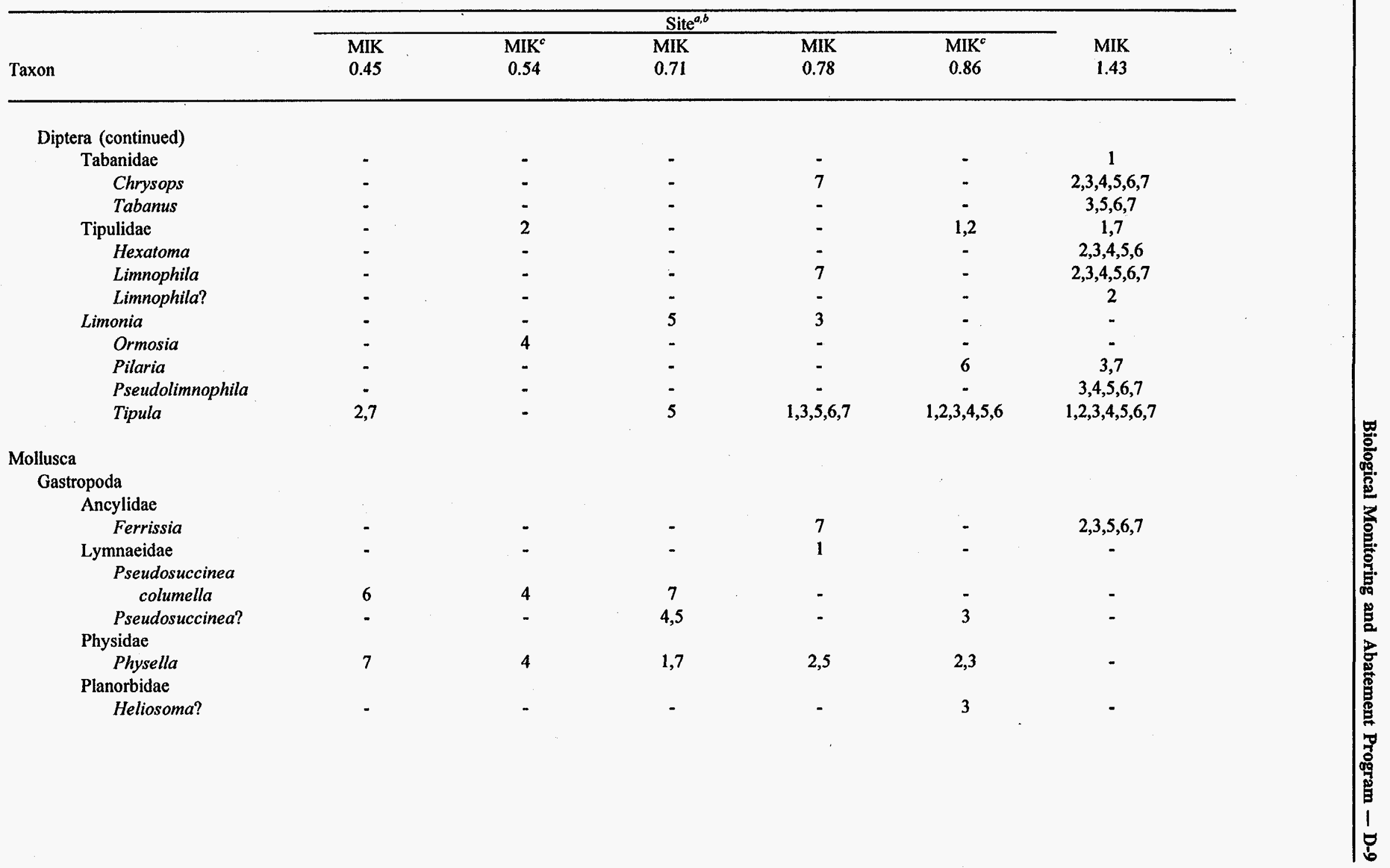


Table D.1 (continued)

\begin{tabular}{|c|c|c|c|c|c|c|}
\hline \multirow[b]{3}{*}{ Taxon } & \multicolumn{5}{|c|}{ Site $^{a, b}$} & \multirow[b]{2}{*}{ MIK } \\
\hline & MIK & $\mathrm{MIK}^{c}$ & MIK & MIK & MIK $^{c}$ & \\
\hline & 0.45 & 0.54 & 0.71 & 0.78 & 0.86 & 1.43 \\
\hline \multicolumn{7}{|l|}{ Bivalvia } \\
\hline Sphaeriidae & - & - & - & - & - & $2,3,4,5,6,7$ \\
\hline Pisidium & 7 & - & - & - & - & $1,2,3,4,7$ \\
\hline Sphaerium & - & - & - & - & - & $1,3,6$ \\
\hline
\end{tabular}

${ }^{a}$ MIK = Mitchell Branch kilometer.

${ }^{6}$ The numbers associated with each taxon and site indicate the sample year(s) within which the taxon was collected at least once: $1=0 \mathrm{ctober} 1986$ and April 1987; $2=$ October 1987 and April 1988; 3=October 1988 and April 1989; 4=October 1989 and April 1990; 5=October 1990 and April 1991; $6=0$ ctober 1991 and April 1992; and 7=October 1992 and April 1993. A blank indicates that a lower level of classification (e.g., family, genus, or species) was possible at one or more sites, and a dash (-) indicates that the taxon was not collected or that the taxon was identified to lower level at one or more sites.

${ }^{c}$ Samples were not collected from MIK 0.54 and MIK 0.86 during the seventh year of the study. 


\section{APPENDIX E}

\section{F-VALUES AND P-VALUES FOR NESTED ANOVAS} AND REGRESSION ANALYSES 


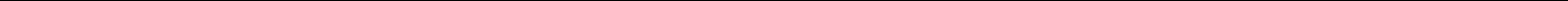


Table E.1. F-values and $p$-values for nested analysis of variance using the response variables density, total richness, and EPT ${ }^{a}$ richness, Mitchell Branch, October 1986-April 1993

\begin{tabular}{|c|c|c|c|c|c|c|c|c|}
\hline \multirow[b]{2}{*}{ Source of variation } & \multicolumn{2}{|c|}{$\mathrm{df}^{b}$} & \multicolumn{2}{|c|}{ Density } & \multicolumn{2}{|c|}{ Total richness } & \multicolumn{2}{|c|}{ EPT richness } \\
\hline & Num & Den & F-value & $p$-value & F-value & $p$-value & F-value & p-value \\
\hline \multicolumn{9}{|c|}{ All Sites ${ }^{c}$} \\
\hline Site & 5 & 30 & 4.47 & 0.0037 & 54.22 & 0.0001 & 34.98 & 0.0001 \\
\hline Year & 5 & 6 & 0.36 & 0.8599 & 2.16 & 0.1883 & 2.06 & 0.2018 \\
\hline Season(Year) & 6 & 30 & 7.70 & 0.0001 & 4.39 & 0.0027 & 3.12 & 0.0171 \\
\hline Site*Year & 25 & 30 & 0.65 & 0.8662 & 1.22 & 0.2980 & 1.25 & 0.2736 \\
\hline Site*Season(Year) & 30 & 144 & 8.51 & 0.0001 & 3.72 & 0.0001 & 3.74 & 0.0001 \\
\hline \multicolumn{9}{|c|}{ Four Sites ${ }^{d}$} \\
\hline Site & 3 & 21 & 7.16 & 0.0017 & 89.12 & 0.0001 & 56.41 & 0.0001 \\
\hline Year & 6 & 7 & 0.58 & 0.7348 & 2.28 & 0.1522 & 3.68 & 0.0559 \\
\hline Season(Year) & 7 & 21 & 3.71 & 0.0091 & 2.74 & 0.0346 & 1.37 & 0.2692 \\
\hline Site*Year & 18 & 21 & 0.83 & 0.6485 & 1.45 & 0.2037 & 1.47 & 0.1987 \\
\hline Site*Season(Year) & 21 & 112 & 9.13 & 0.0001 & 3.87 & 0.0001 & 3.22 & 0.0001 \\
\hline
\end{tabular}

${ }^{a} \mathrm{EPT}=$ Ephemeroptera, Plecoptera, and Trichoptera

${ }^{b} \mathrm{df}=$ degrees of freedom; Num $=$ numerator; Den $=$ Denominator

${ }^{c}$ Analysis included all six sites but included data from the first 6 years only (October 1986-April 1992).

${ }^{d}$ Analysis included Mitchell Branch kilometers 0.45, 0.71, 0.78, and 1.43 only but included data from all 7 years (October 1986-April 1993). 
Table E.2. F-values and p-values for regression analyses testing for equal slopes across sites using the response variables density, total richness, and EPT ${ }^{a}$ richness, Mitchell Branch, October 1986-April 1993

\begin{tabular}{|c|c|c|c|c|c|c|c|c|}
\hline \multirow[b]{2}{*}{ Source of variation } & \multicolumn{2}{|c|}{$\mathrm{df}^{b}$} & \multicolumn{2}{|c|}{ Density } & \multicolumn{2}{|c|}{ Total richness } & \multicolumn{2}{|c|}{ EPT richness } \\
\hline & Num & Den & F-value & $p$-value & F-value & $p$-value & F-value & $p$-value \\
\hline \multicolumn{9}{|c|}{ Six Years Yed $^{c, d}$} \\
\hline \multicolumn{9}{|l|}{ All sites } \\
\hline Fall & 5 & 96 & 4.15 & 0.0019 & 1.80 & 0.1209 & 1.12 & 0.3538 \\
\hline Spring & 5 & 96 & 20.01 & 0.0001 & 7.58 & 0.0001 & 3.01 & 0.0144 \\
\hline \multicolumn{9}{|c|}{ MIK 0.54 vs MIK 1.43} \\
\hline Fall & 1 & 32 & 8.02 & 0.0079 & 0.97 & 0.3314 & 2.50 & 0.1234 \\
\hline Spring & 1 & 32 & 4.57 & 0.0402 & 4.96 & 0.0330 & 0.00 & 0.9913 \\
\hline \multicolumn{9}{|c|}{ MIK 0.86 vs MIK 1.43} \\
\hline Fall & 1 & 32 & 0.20 & 0.6570 & 0.31 & 0.5794 & 0.00 & 0.9557 \\
\hline Spring & 1 & 32 & 0.05 & 0.8276 & 6.41 & 0.0165 & 3.74 & 0.0621 \\
\hline \multicolumn{9}{|c|}{ All Years ${ }^{e}$} \\
\hline \multicolumn{9}{|l|}{ All sites } \\
\hline Fall & 3 & 76 & 3.64 & 0.0163 & 3.67 & 0.0158 & 1.80 & 0.1549 \\
\hline Spring & 3 & 76 & 12.76 & 0.0001 & 6.17 & 0.0008 & 3.06 & 0.0333 \\
\hline \multicolumn{9}{|c|}{ MIK 0.45 vs MIK 1.43} \\
\hline Fall & 1 & 38 & 1.64 & 0.2080 & 0.52 & 0.4753 & 4.14 & 0.0488 \\
\hline Spring & 1 & 38 & 3.19 & 0.0822 & 2.35 & 0.1337 & 0.04 & 0.8491 \\
\hline \multicolumn{9}{|c|}{ MIK 0.71 vs MIK 1.43} \\
\hline Fall & 1 & 38 & 5.40 & 0.0255 & 15.90 & 0.0003 & 2.89 & 0.0972 \\
\hline Spring & 1 & 38 & 14.72 & 0.0004 & 13.02 & 0.0009 & 5.52 & 0.0241 \\
\hline \multicolumn{9}{|c|}{ MIK 0.78 vs MIK 1.43} \\
\hline Fall & 1 & 38 & 0.39 & 0.5369 & 1.60 & 0.2137 & 0.00 & 0.9544 \\
\hline Spring & 1 & 38 & 3.97 & 0.0537 & 1.39 & 0.2452 & 0.26 & 0.6133 \\
\hline
\end{tabular}

${ }^{a} \mathrm{EPT}=$ Ephemeroptera, Plecoptera, and Trichoptera

${ }^{b} \mathrm{df}=$ degrees of freedom; Num = numerator; Den = Denominator

qMIK = Mitchell Branch kilometer.

${ }^{d}$ Analysis included all six sites but included data from the first 6 years only (October 1986-April 1992).

${ }^{e}$ Analysis included Mitchell Branch kilometers $0.45,0.71,0.78$, and 1.43 only but included data from all 7 years (October 1986-April 1993). 
APPENDIX F

SEASONAL REGRESSION LINES FOR DENSITY, TOTAL RICHNESS, AND EPT RICHNESS 


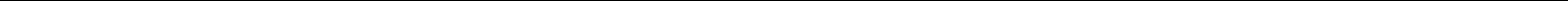



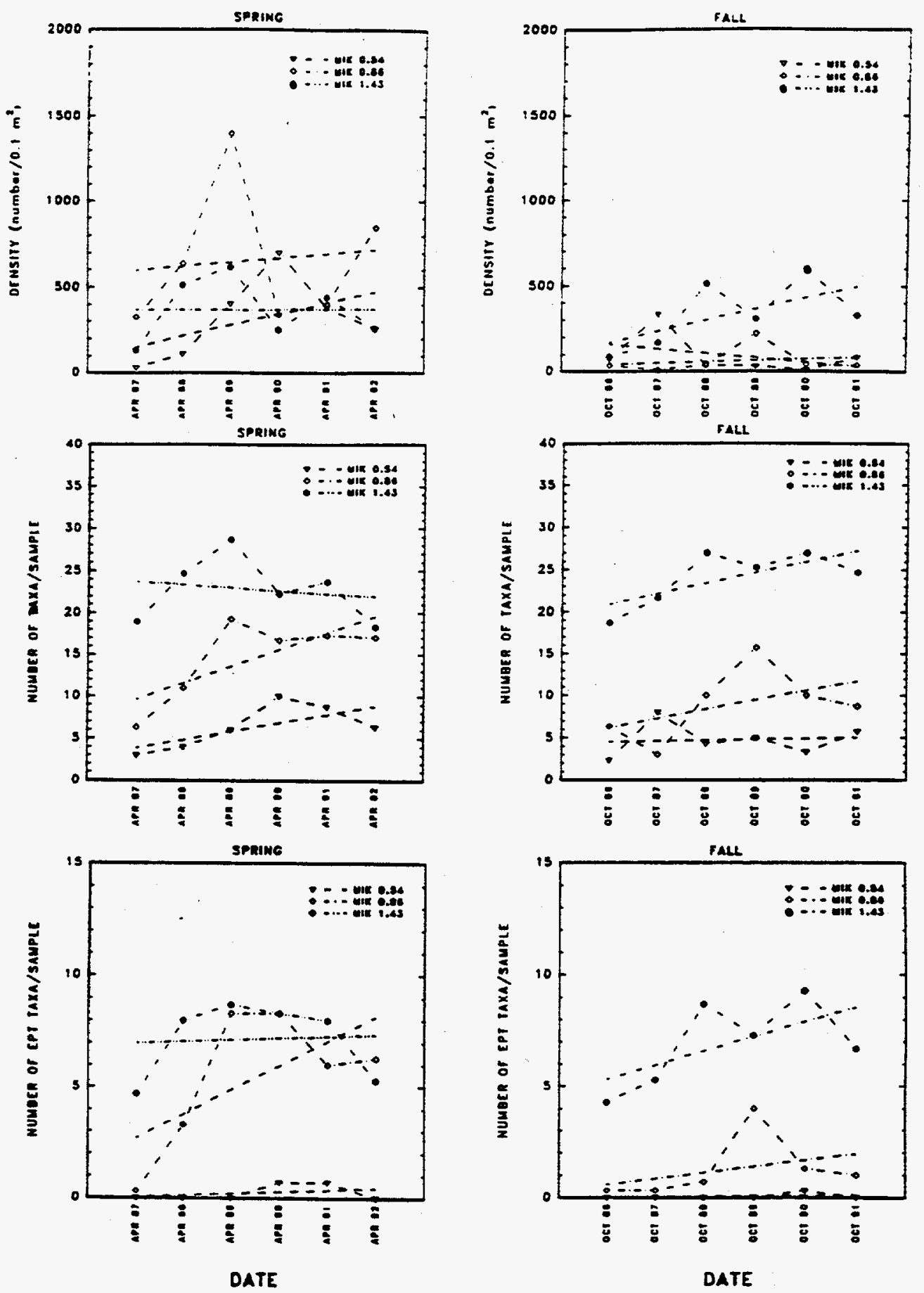

Fig. F.1. Seasonal regression lines for total density, total richness, and richness of the Ephemeroptera, Plecoptera, and Trichoptera (EPT richness) of the benthic macroinvertebrate communities in Mitchell Branch, October 1986-April 1992. Estimates of error (i.e., standard error) are available in Fig. 6.1. MIK = Mitchell Branch kilometer. Spring $=$ April sampling periods; Fall $=$ October sampling periods. 

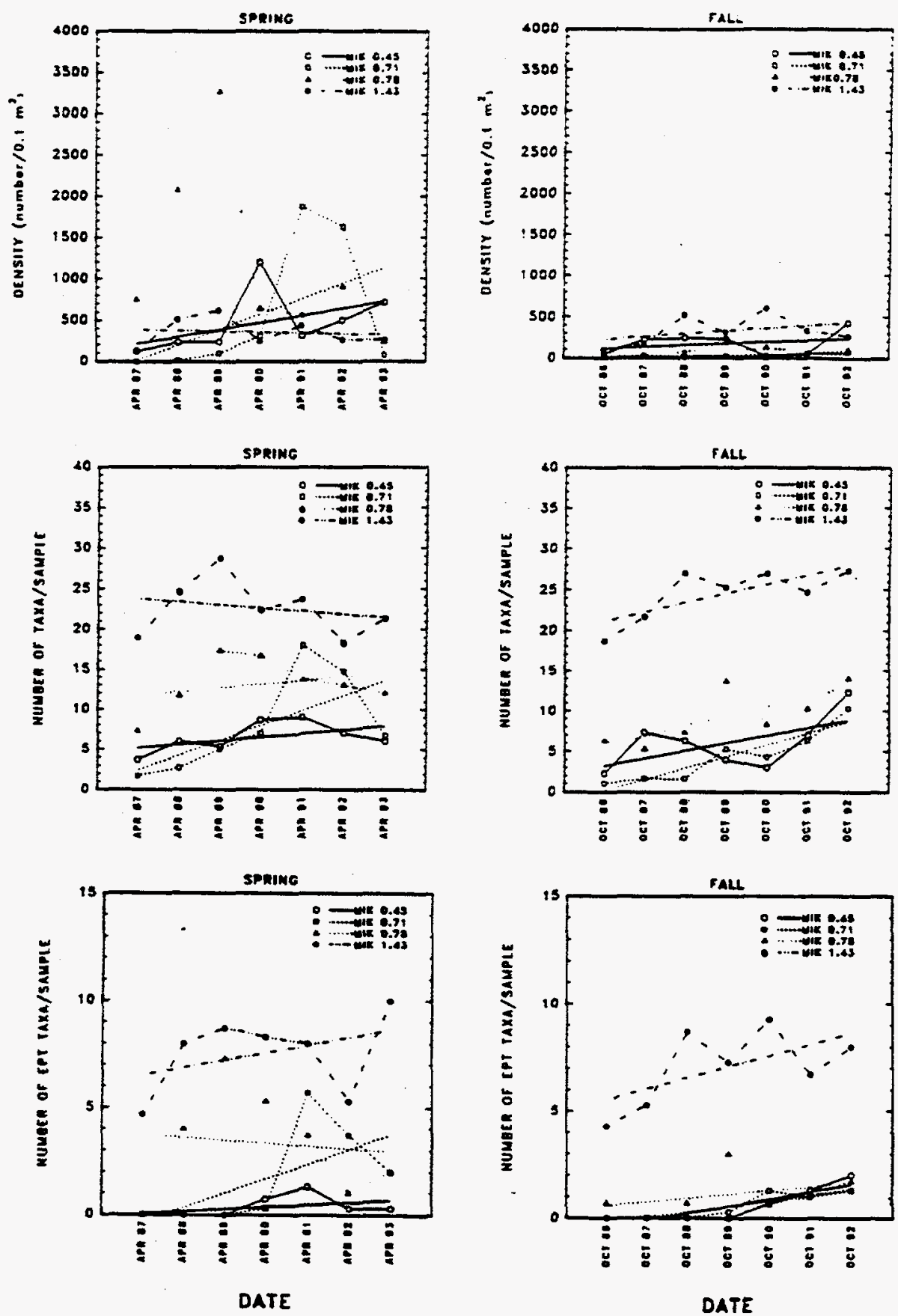

Fig. F.2. Seasonal regression lines for total density, total richness, and richness of the Ephemeroptera, Plecoptera, and Trichoptera (EPT richness) of the benthic macroinvertebrate communities in Mitchell Branch, October 1986-April 1993. Estimates of error (i.e., standard error) are available in Fig. 6.1. MIK = Mitchell Branch kilometer. Spring $=$ April sampling periods; Fall $=$ October sampling periods. 
APPENDIX G

LENGTH FREQUENCY DISTRIBUTION OF FISHES

IN MITCHELL BRANCH 


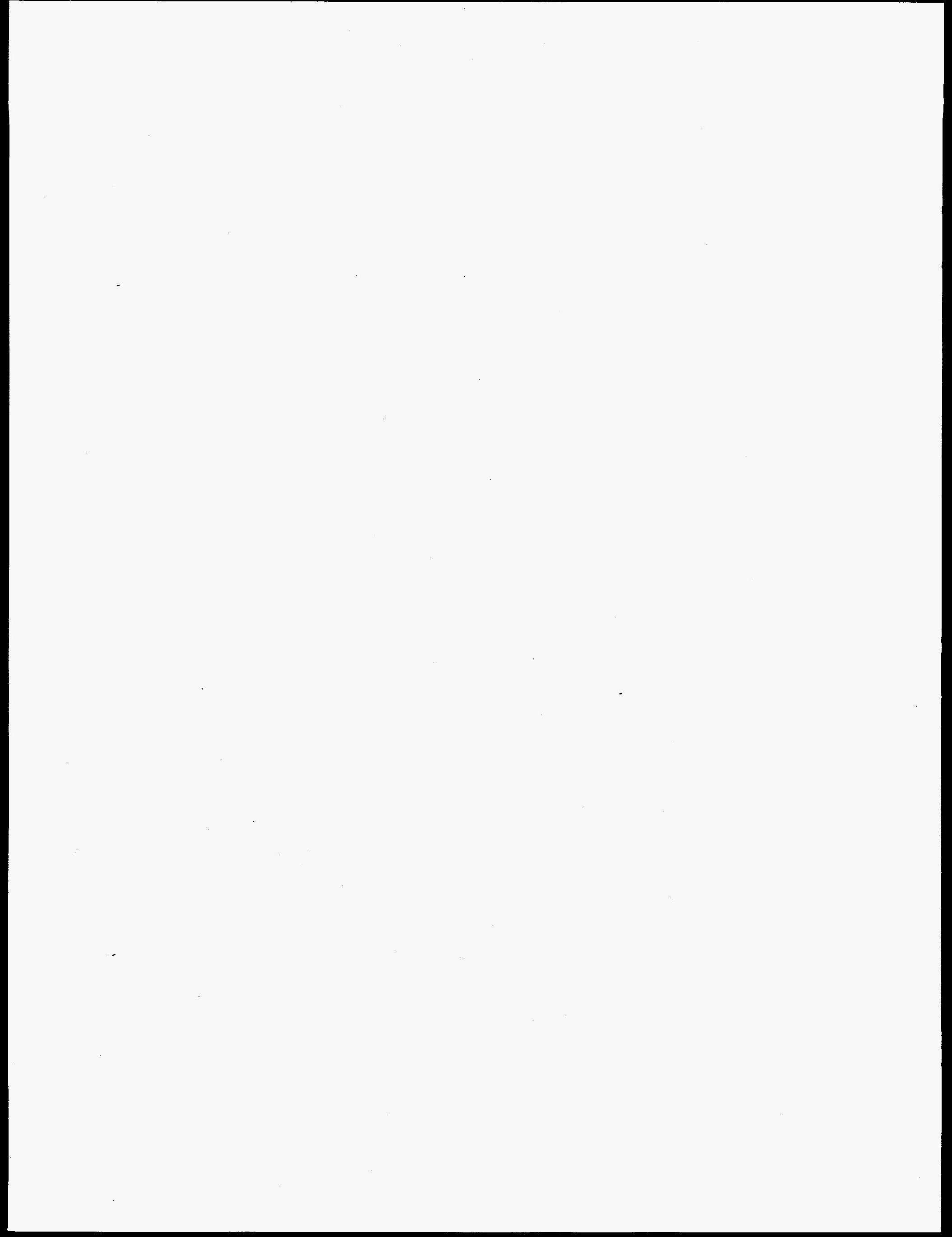



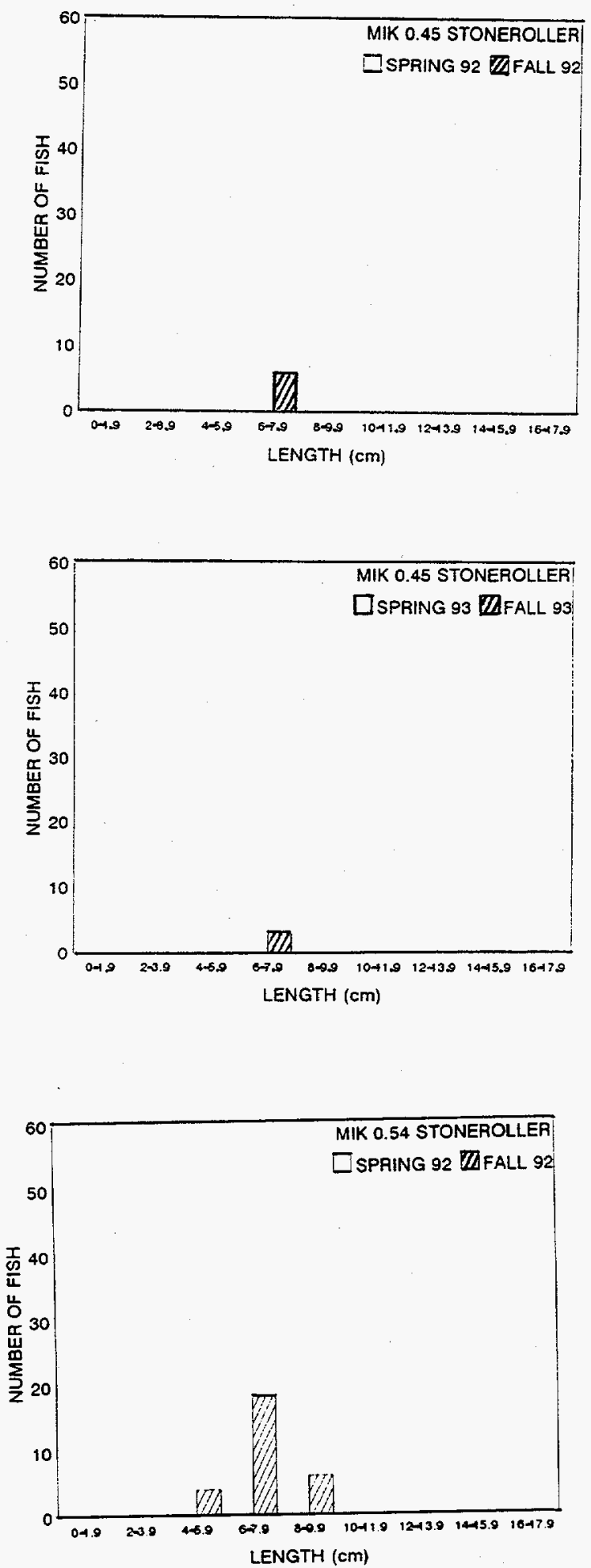

Fig. G.1. Length-frequency distribution of estimated populations of central stoneroller in Mitchell Branch (MIK) from spring 1992 through fall 1993. 

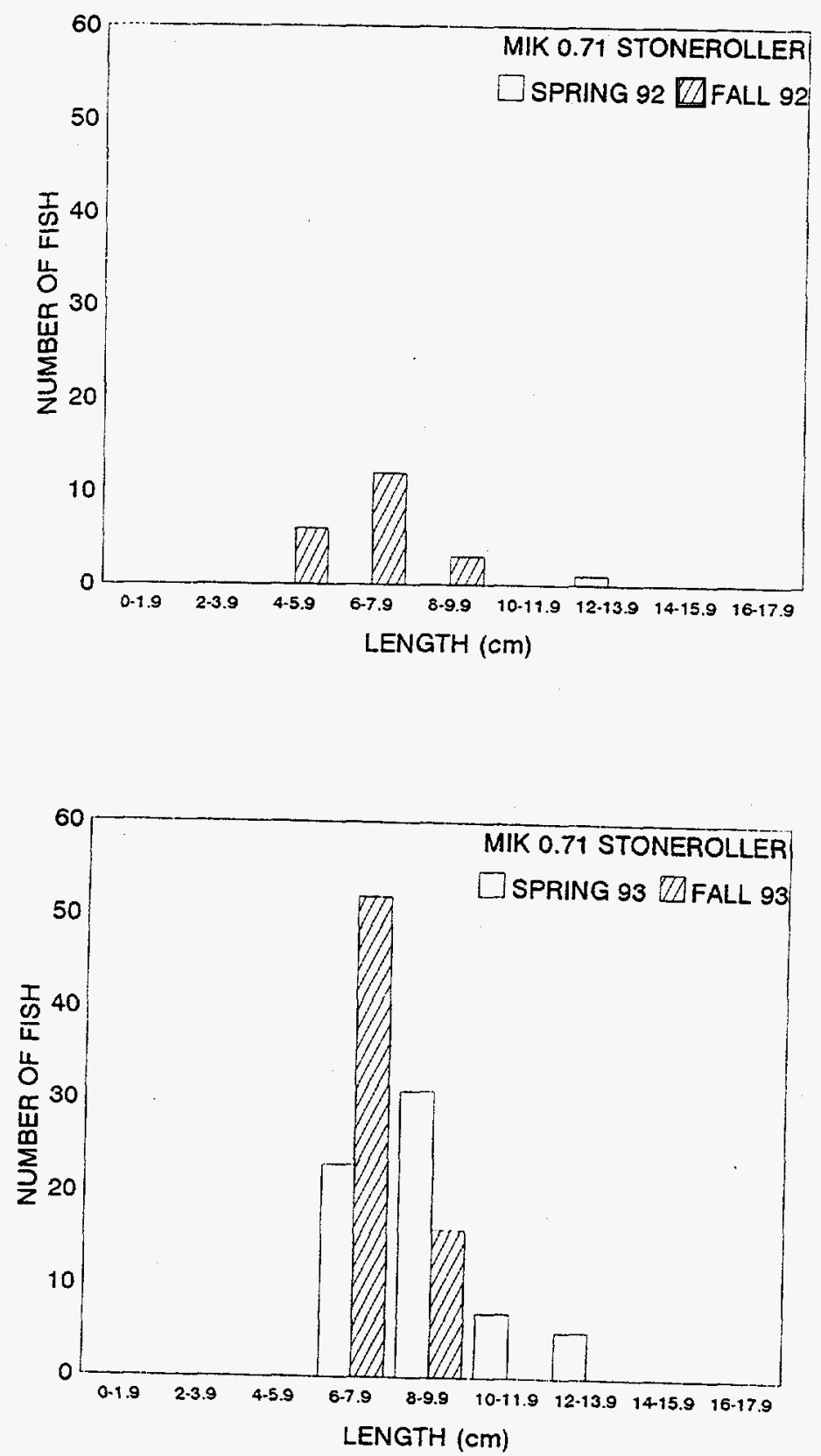

Fig. G.2. Length-frequency distribution of estimated populations of central stoneroller in Mitchell Branch (MIK) from spring 1992 through fall 1993. 

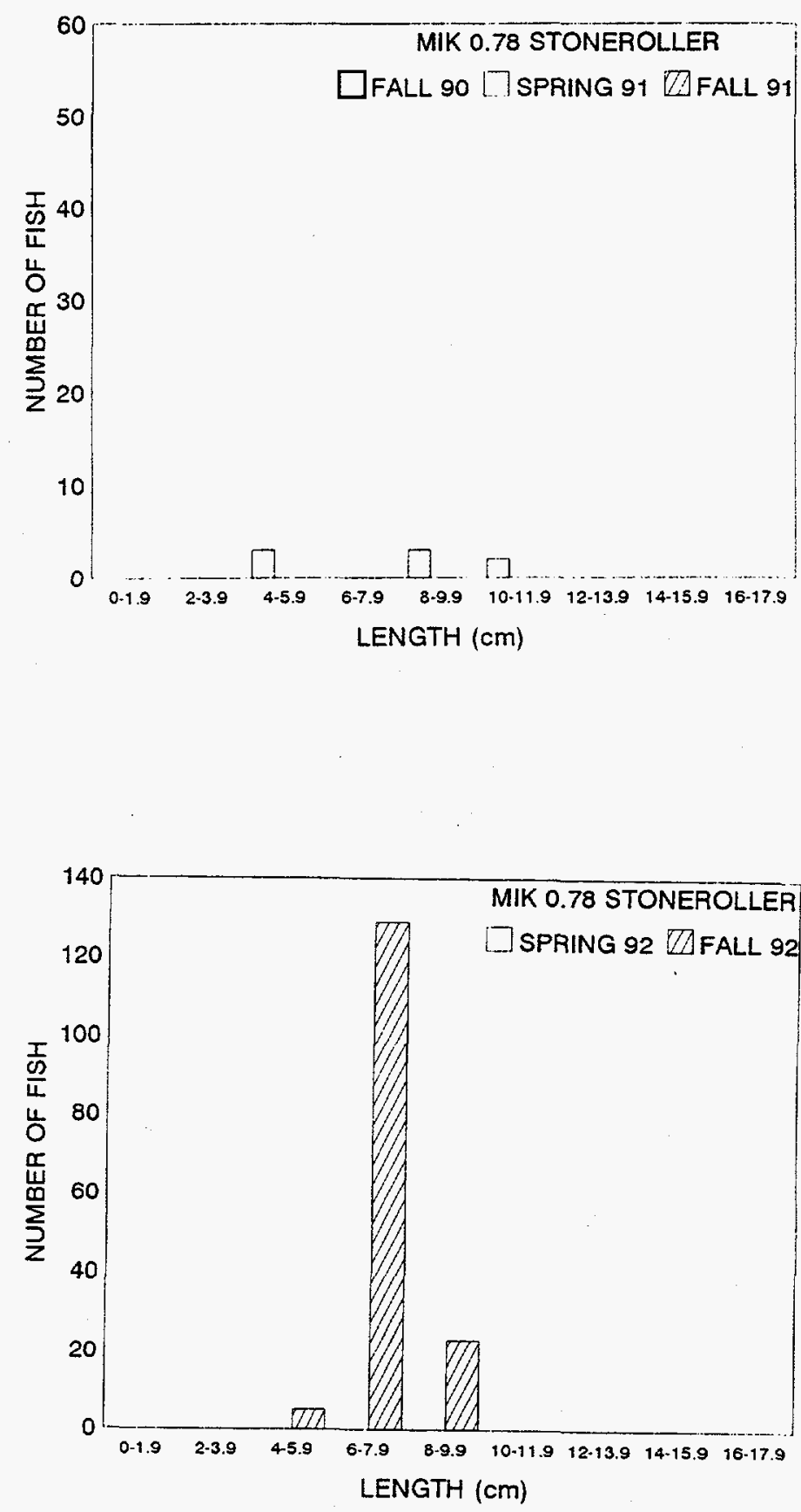

Fig. G.3. Length-frequency distribution of estimated populations of central stoneroller in Mitchell Branch (MIK) from fall 1990 through fall 1992. 

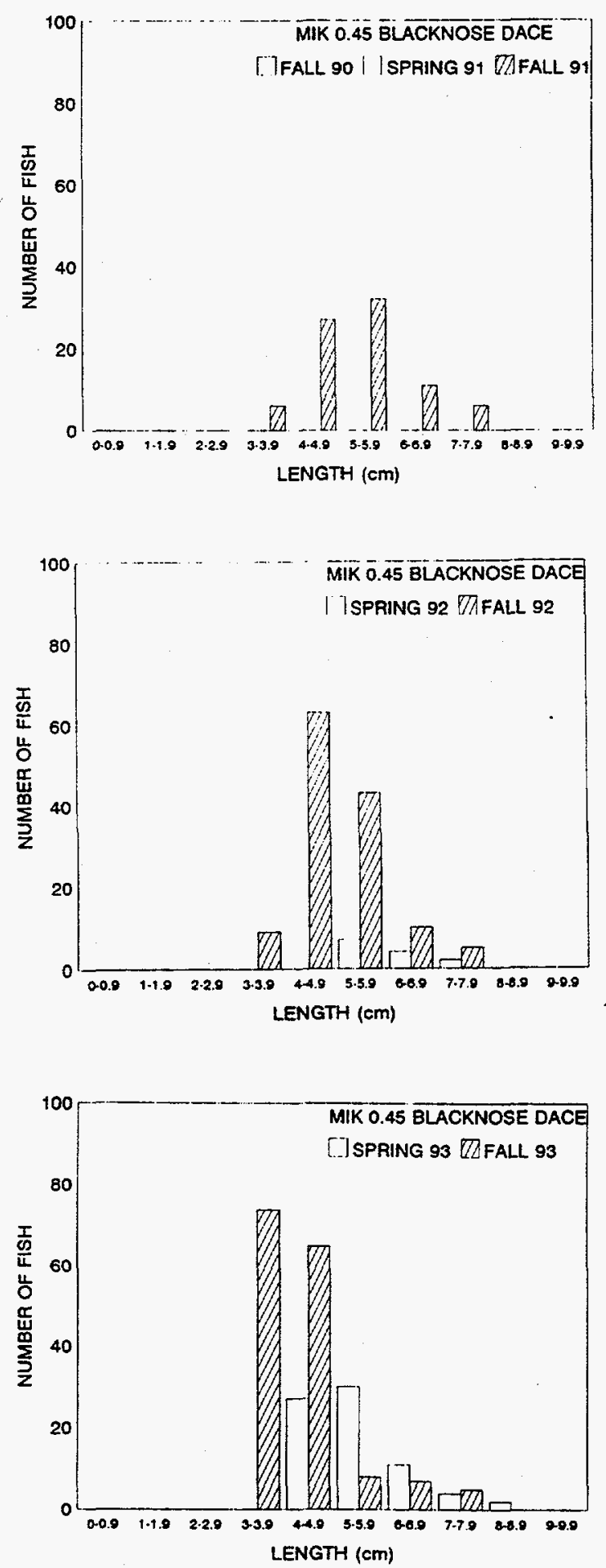

Fig. G.4. Length-frequency distribution of estimated populations of blacknose dace (BNDACE) in Mitchell Branch (MIK) from fall 1990 through fall 1993. 

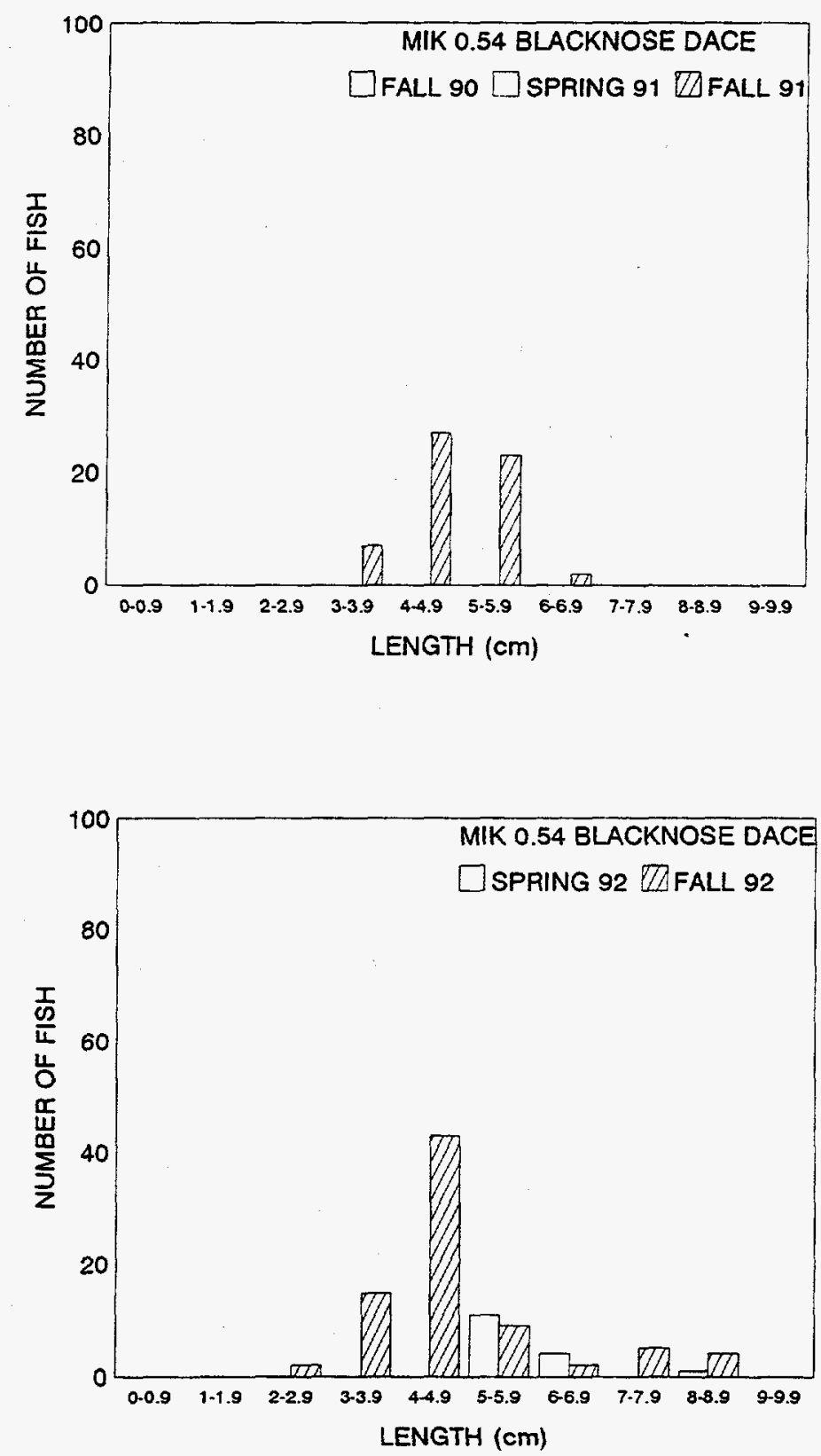

Fig. G.5. Length-frequency distribution of estimated populations of blacknose dace (BNDACE) in Mitchell Branch (MIK) from fall 1990 through fall 1992. 

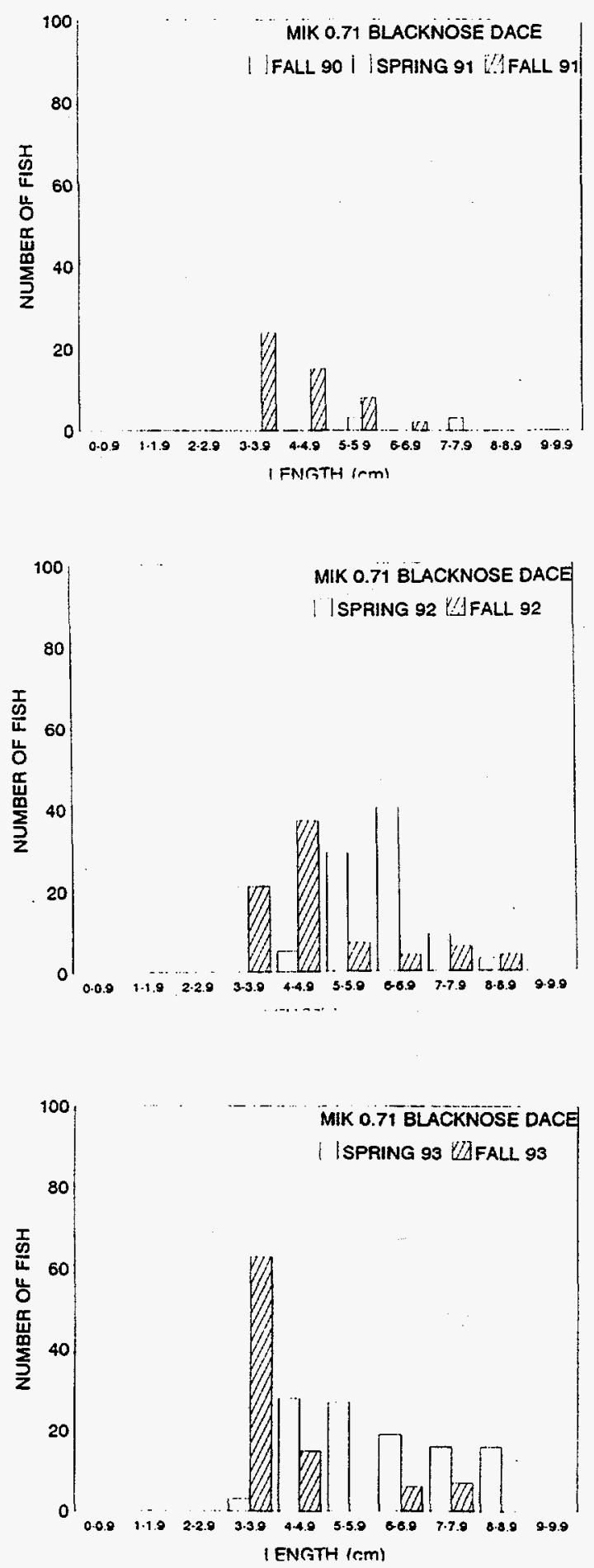

Fig. G.6. Length-frequency distribution of estimated populations of blacknose dace (BNDACE) in Mitchell Branch (MIK) from fall 1990 through fall 1993. 

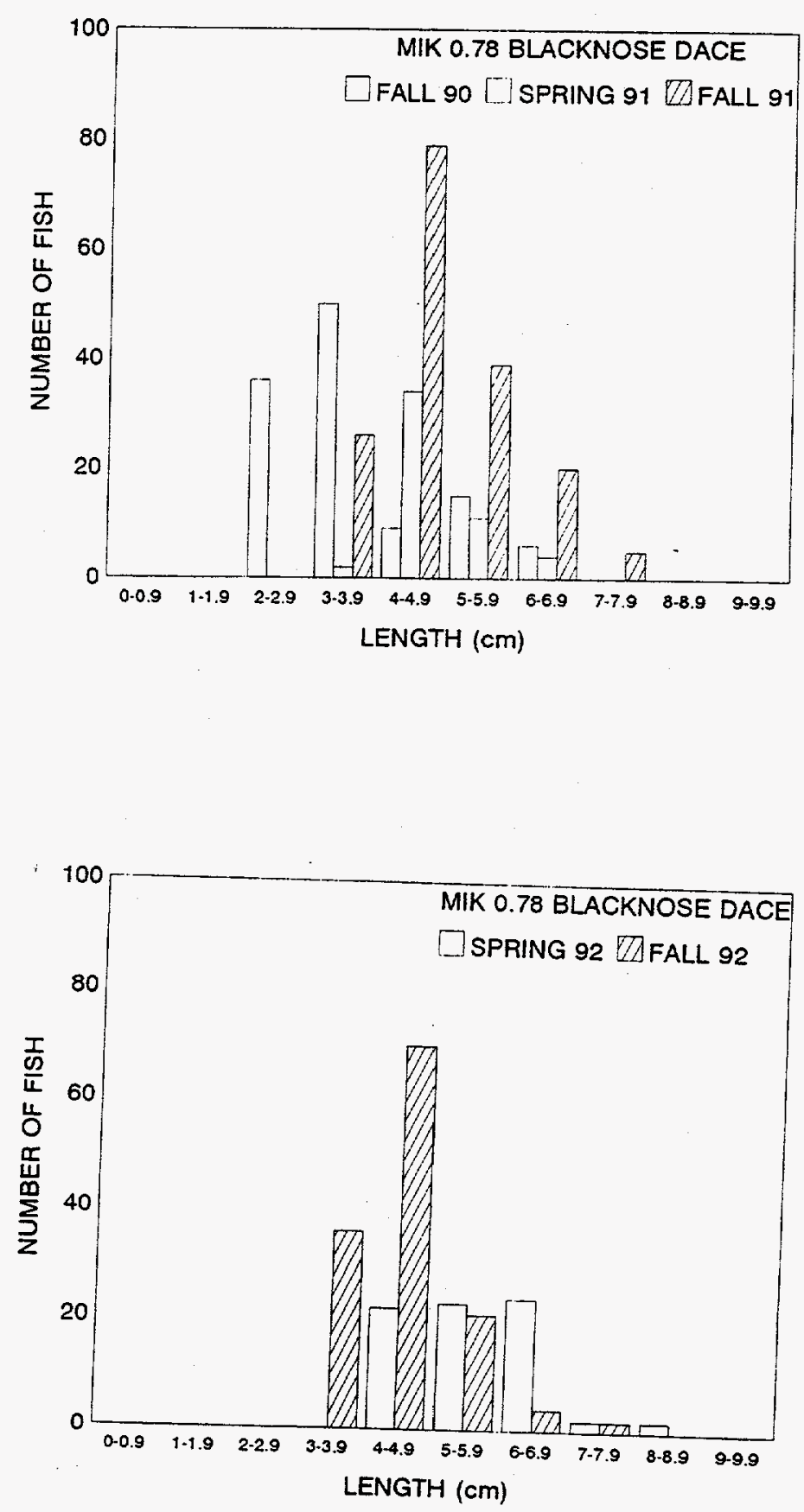

Fig. G.7. Length-frequency distribution of estimated populations of blacknose dace (BNDACE) in Mitchell Branch (MIK) from fall 1990 through fall 1992. 

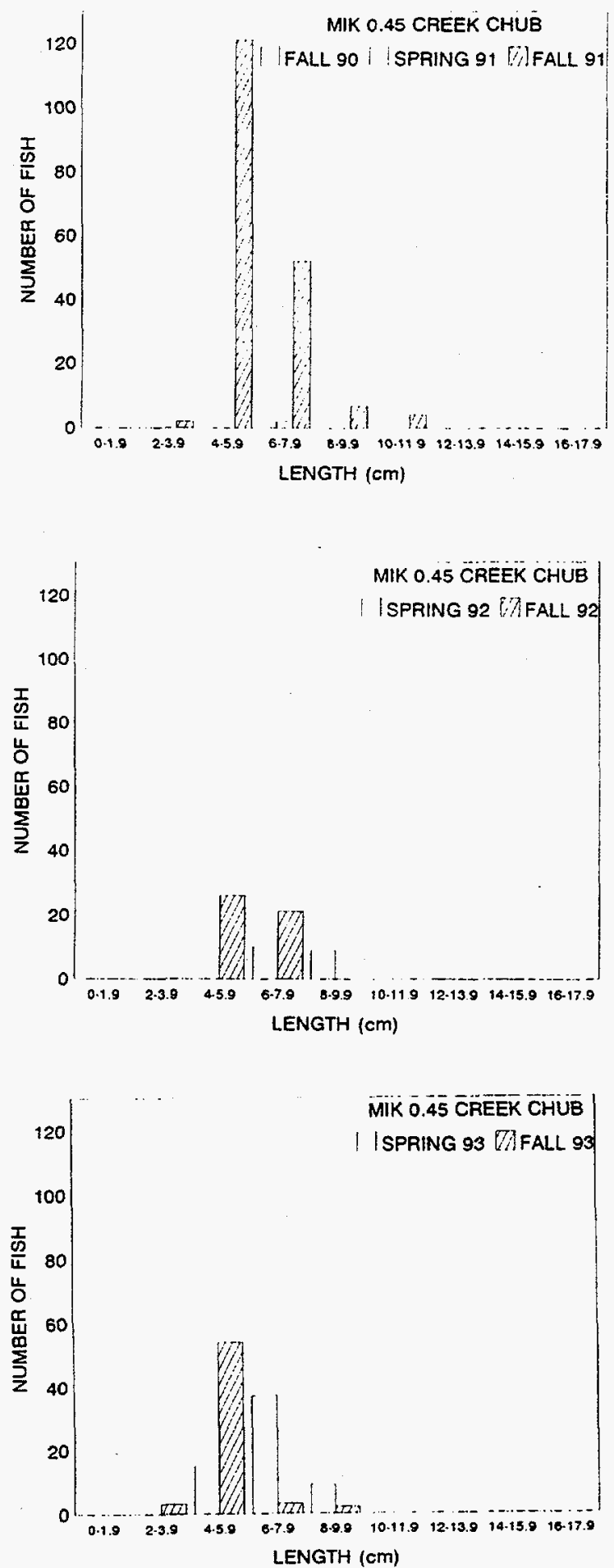

Fig. G.8. Length-frequency distribution of estimated populations of creek chub in Mitchell Branch (MIK) from fall 1990 through fall 1993. 

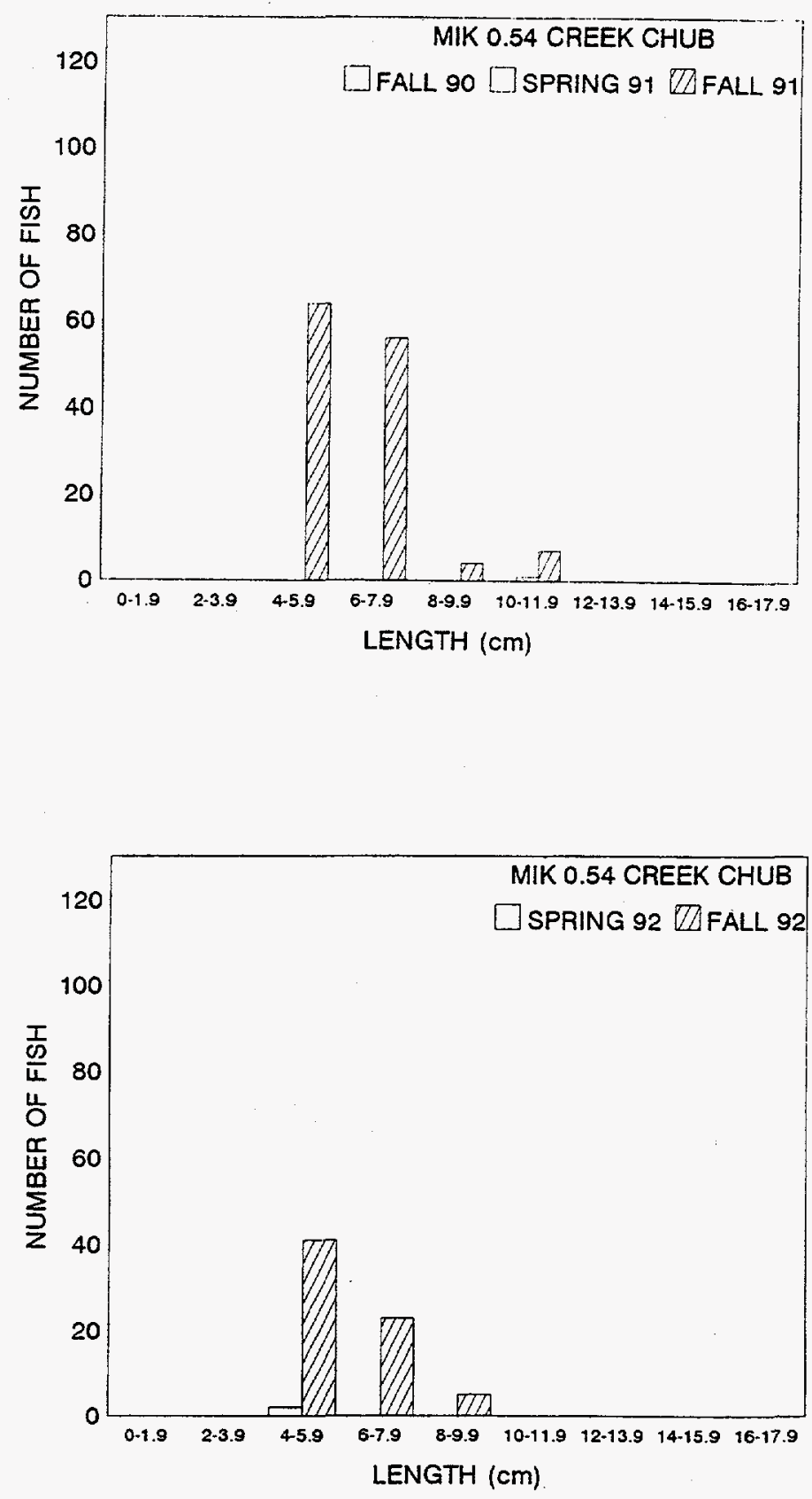

Fig. G.9. Length-frequency distribution of estimated populations of creek chub in Mitchell Branch (MIK) from fall 1990 through fall 1992. 

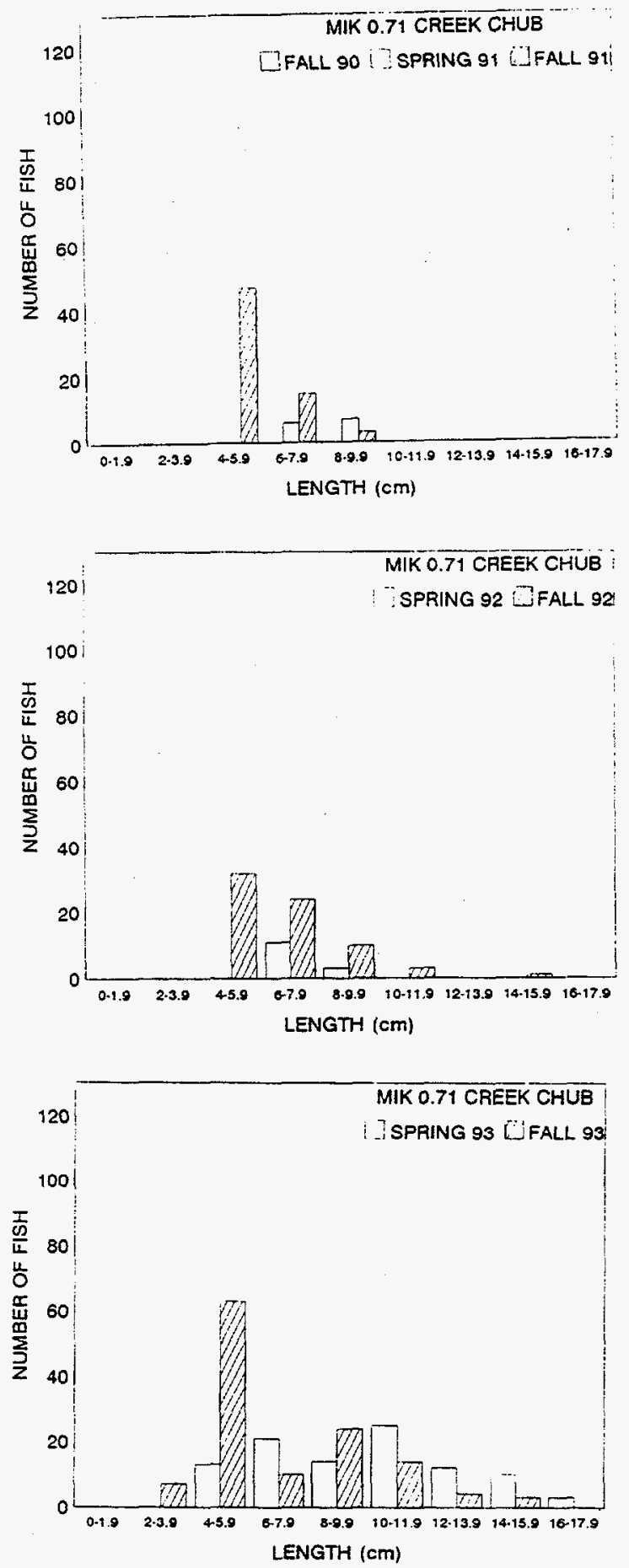

Fig. G.10. Length-frequency distribution of estimated populations of creek chub in Mitchell Branch (MIK) from fall 1990 through fall 1993. 

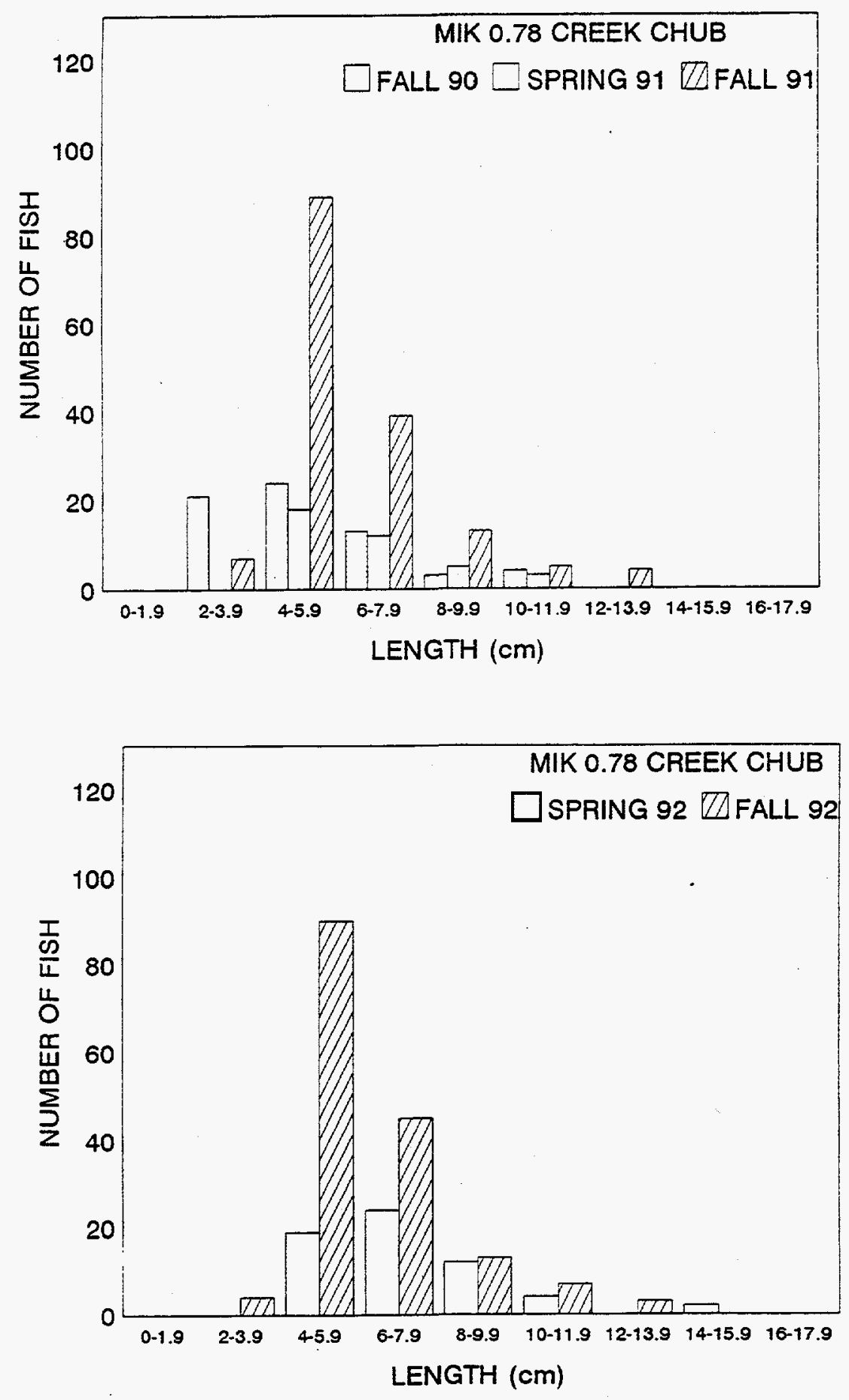

Fig. G.11 Length-frequency distribution of estimated populations of creek chub in Mitchell Branch (MIK) from fall 1990 through fall 1992. 
ORNL/TM-12790

\section{INTERNAL DISTRIBUTION}

1. S. M. Adams

2. T. L. Ashwood

3. L. A. Baron

4. L. D. Bates

5. B. K. Beane

6. B. A. Berven

7. S. W. Christensen

8. M. L. Coffee

9. D. E. Conrad

10. R. B. Cook

11. V. H. Dale

12. R. J. Devol

13. C. E. Duncan

14. R. C. Durfee

15. N. T. Edwards

16. C. J. Ford

17. J. M. Forstrom

18. D. E. Fowler

19. G. A. Goslow

20. J. D. Hankins

21. P. L. Henry

22. S. G. Hildebrand

23-32. R. L. Hinzman

33. G. K. Jacobs

34. D. S. Jones

35. P. Kanciruk

36. B. L. Kimmel

37. E. H. Krieg, Jr.

38-47. L. A. Kszos

48. J. M. Loar

49. S. A. Meacham

50. J. L. Murphy
51. F. R. O'Donnell

52-53. P. T. Owen

54-58. M. J. Peterson

59. R. B. Petrie

60. T. L. Phipps

61. D. A. Poole

62. D. E. Reichle

63. R. A. Rich

64. W. K. Roy

65. M. G. Ryon

66. T. K. Sawyer

67. E. M. Schilling

68. J. A. Shaakir-Ali

69. F. E. Sharples

70. L. G. Shipe

71. D. S. Shriner

72. L. R. Shugart

73. J. G. Smith

74. G. R. Southworth

75. L. E. Stokes

76. J. R. Sumner

77. G. W. Suter

78. S. Talmage

79. C. C. Travis

80. J. K. Williams

81. Central Research Library

82-83. ESD Library

84-98. Laboratory Records Dept.

99. Laboratory Records, ORNL-RC

100. ORNL Patent Section

101. ORNL Y-12 Technical Library

\section{EXTERNAL DISTRIBUTION}

102. D. L. Ashburn, Lockheed Martin, 761 Veterans Avenue, Kevil, KY 42053

103. E. B. Bryant, Science Applications International Corporation, 301 Laboratory Road, Oak Ridge, TN 37931

104. F. A. Donath, Director, Institute for Environmental Education, Geological Society of America, 1006 Las Posas, San Clemente, CA 92673

105. R. N. Farvolden, Professor, Department of Earth Sciences, University of Waterloo, Waterloo, Ontario N2L 3G1 Canada

106. D. W. Freckman, Director, College of Natural Resources, 101 Natural Resources Building, Colorado State University, Fort Collins, CO 80523 
107. D. R. Guminski, Lockheed Martin, 761 Veterans Avenue, Kevil, KY 42053

108. A. Patrinos, Associate Director, Environmental Sciences Division, Office of Health and Environmental Research, G-165, U.S. Department of Energy, Germantown, MD 20874

109. G. S. Sayler, Professor, 10515 Research Drive, Suite 100, The University of Tennessee, Knoxville, TN 37923-2567

110 F. J. Wobber, Environmental Sciences Division, Office of Health and Environmental Research, ER-74, U.S. Department of Energy, Washington, DC 20585

111. Office of Assistant Manager for Energy Research and Development, U.S. Department of Energy Oak Ridge Operations, P.O. Box 2001, Oak Ridge, TN $37831-8600$

112-113. Office of Scientific and Technical Information, P.O. Box 62, Oak Ridge, TN 37831 